\title{
Evaluation of Dust Cake Filtration at High Temperature With Effluence From an Atmospheric Fluidized-Bed Combustor
}

\author{
Technical Note
}

R. A. Dennis

U.S. Department of Energy

Office of Fossil Energy

Morgantown Energy Technology Center

P.O. Box 880

Morgantown, West Virginia 26507-0880

August 1990 


\section{ABSTRACT}

The results of a test series designed to evaluate dust cake filtration properties at high temperature $\left(1,300^{\circ} \mathrm{F}\right)$ with particulate from an atmospheric fluidized-bed combustor (AFBC) are presented. The tests explored filtration phenomena on a single, full-size, ceramic, candle filter and on a small-scale disc filter. The AFBC was fired with Pittsburgh No. 8 coal with limestone sand as the sorbent. Combustor exhaust gas typically exited with a particulate concentration of 7,500 ppmw. Three separate particulate size distributions and loadings were generated for the study using two different cyclone configurations and the unaltered combustor exhaust gas. The main variable explored in the candle fiiter tests was particle size distribution; the disc filter tests examined dust cake thickness, particulate size distribution, and filter face velocity. Three candle filter tests and 11 disc filter tests were cunducted. The main result from the study indicated that on average a $33 \%$ reduction in mean particulate size produced a $498 \%$ increase in the dust-cake specific flow resistance $\left(K_{2}\right)$. 


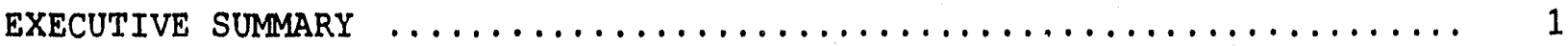

$1.0 \quad$ INTRODUCTION. ..................................

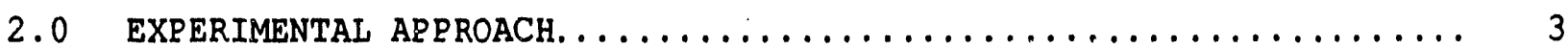

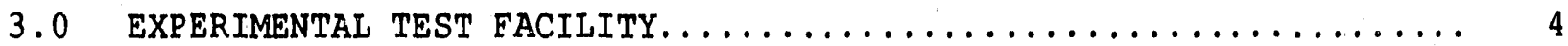

3.1 Description of the 6-Inch Atmospheric Fluidized-Bed

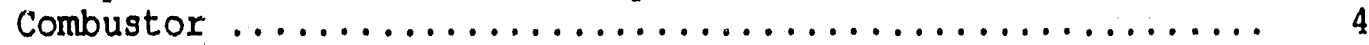

3.2 Description of the Candle Filter Vessel ............... 8

3.3 Description of the Disc Filter Vessel ................. 13

3.4 Description of the Cyclone system .................... 15

3.5 Gas Stream Sampling with the Disc Filter Vessel .......... 16

4.0 CHARACTERISTICS AND OPERATION OF THE TEST FACILITY........... 18

4.1 Operational Characteristics of the Atmospheric Fluidized-Bed Combustor ..................... 18

4.2 Operational Characteristics of the Cyclone system .......... 20

4.3 Operational Characteristics of the Candle Filter Vessel ..... 20

4.4 Operational Characteristics of The Disc Filter Vessel ...... 22

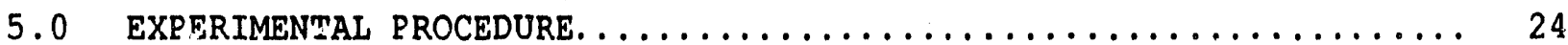

6.0 TEST RESULTS. ...............................

6.1 Candle Filter Test Results ....................... 26

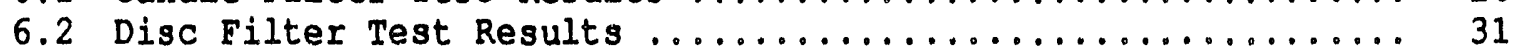

6.3 Discussion of Results .......................... 32

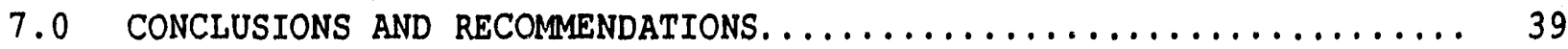

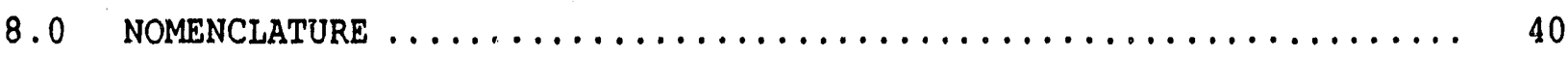

9.0 ABBREVIATIONS AND ACRONYMS $\ldots \ldots \ldots \ldots \ldots \ldots \ldots \ldots$

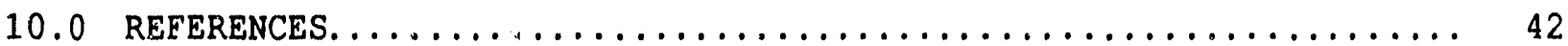


APPENDICES

Appendix A: Dust and Bed Material Data .................... 44

Appendix B: Process Variable Plots for Candle Filter Tests CF1,

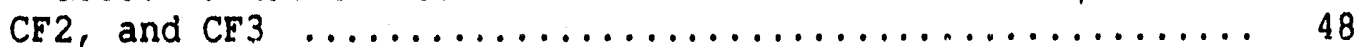

Appendix C: Process Variable Plots for Disc-Filter Dust Loading Tests DF1 Through DF11 ....................... 59

Appendix D: Process Variables With Hot Nitrogen in the Disc-Filter

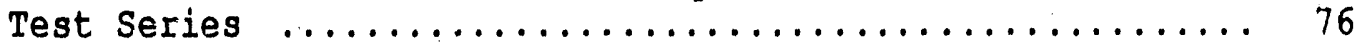

Appendix E: SEM, Chemical, and Physical Analyses of Dust Cakes in the Candle-Filter Test Series ............... 90

Appendix F: Laboratory Characterization of Filter Dust by Southern Research Institute 95

\section{IIST OF TIGORES}

\section{Fiqure}

1 Conceptual Schematic of the AFBC Particulate-Cleanup Test Facility

2 Simplified Process Flow and Instrumentation Diagram of the AFBC Partizulate-Cleanup Test Facility ................ 6

3 Schematic of 6 -Inch AFBC Vessel $\ldots \ldots \ldots \ldots \ldots \ldots \ldots \ldots \ldots$

4 Schematic of Candle Filter vessel ..................... 9

5 Dimensions of the Refractron RI-20 Candle Filter ............ 11

$6 \quad$ Candle-Filter Tubesheet and Hold-Down Flange $\ldots \ldots \ldots \ldots \ldots \ldots \ldots$

7 Candle-Filter Dust-Cake-Thickness Detector $\ldots \ldots \ldots \ldots \ldots \ldots \ldots \ldots$

8 Schematic of Disc Filter Vessel ..................... 14

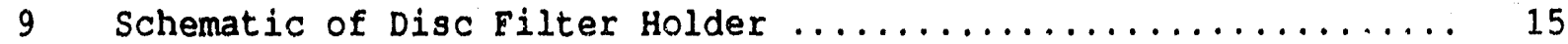

10 Isokinetic Sampling Probe for the Disc Filter Vessel ........ 16

11 Insert for the Isokinetic Sampling Probe $\ldots \ldots \ldots \ldots \ldots \ldots$ 


\section{IIST OF TIGURES}

(Continued)

Eiqure

12 Vertical Temperature Profile Through the 6-Inch AFBC

13 Characteristic Pressure Drop Versus Time for a Barrier

Filter

14 Pressure Drop Versus Time Signature for Candle

Filter Test CF1 ............................... 49

15 Filter flow Rate versus Time for Candle Filter Test CF1 ...... 49

16 Filter Face Velocity Versus Time for Candle Filter Test CF $1 \ldots . .50$

17 Filtrate Temperatures versus Time for Candle Filter Test CF1 ... 5 C

18 Candle Filter vessel Pressure for Candle Filter Test CF $1 \ldots . . .$.

19 Pressure Drop Versus Time Signature for Candle Filter

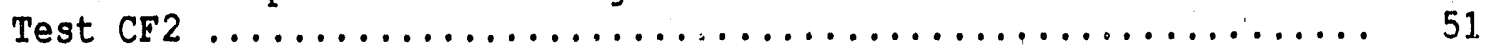

20 Filter Flow Rate Versus Time for Candle Filter Test CF2 ..... 52

21 Filter Face Velocity versus Time for Candle Filter Test CF2 ....

Filtrate Temperatures Versus Time for Candle Filter Test CF2 ... 53

Candle Filter Vessel Pressure for Candle Filter Test CF2 ......

24 Pressure Drop Versus Time Signature for the Second Part of Candle Filter Test CF2 ....................... 54

25 Filter Flow Rate Versus Time for the Second Part of Candle Filter Test CF2 ............................... 54

26 Filter Face Velocity Versus Time for the Second Part of Candle Filter Test CF2 ......................... 55

27 Filtrate Temperature Versus Time for the Second Part of Candle Filter Test CF2 .......................... 55

28 Candle Filter Vessel pressure for the Second part of Candle Filter Test CF2 ........................ 56

29 Pressure Drop Versus Time Signature for Candle Filter

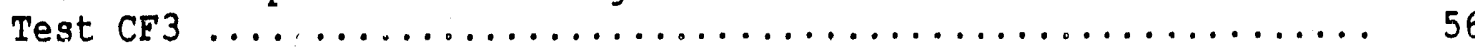




\section{LIST OF TIGURES}

(Continued)

Fiquse

Page

Filter Flow Rate Versus Time for Candle Filter Test CF3 ....... 57

31 Filter Face Velocity Versus Time for Candle Filter Test CF3 ....

32 Tiltrate Temperatures versus Time for Candle Filter

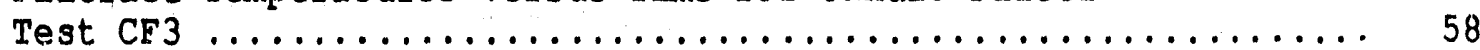

Candle Filter Vessel Pressure for Candle Filter Test CF $3 \ldots \ldots .58$

34 Pressure Drop, Flow Rate, and Face Velocity During Disc Filter Test DF2 ............................... 61

Disc Filter Outlet Temperature During Disc Filter Test DF2 ....

Disc Filter Vessel Pressure During Disc Filter Test DF2 .......

37 Pressure Drop, Flow Rate, and Face Velocity During Disc Filter Test DF3

Disc Filter Outlet Temperature During Disc Filter Test DF3 .....

Disc Filter Vesse1. Pressure During Disc Filter Test DF3 .......

40 Pressure Drop, Flow Rate, and Face Velocity During Disc Filter Test DF4

Disc Filter Outlet Temperature During Disc Filter Test DF4 .....

Disc Filter Vessel Pressure During Disc Filter Test DF4 .......

43 Pressure Drop, Flow Rate, and Face Velocity During Disc Filter Test DF5

\section{Pressure Drop, Flow Rate, and Face Velocity During}

Disc Filter Test DF6 
49 Fressure Drop, Flow Rate, and Face Velocity During visc Filter Test DF $7 \ldots \ldots \ldots \ldots \ldots \ldots \ldots \ldots \ldots \ldots \ldots \ldots \ldots$

50 Disc Filter Outlet Temperature During Disc Filter Test DF7 ... 69

51 Disc Filter Vessel pressure During DisC Filter Test DF' ...... 69

52 Pressure Drop, Flow Rate, and Face Velocity During

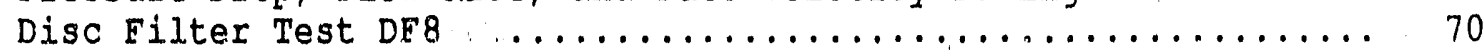

53 Disc Filter Outlet Temperature During Disc Filter Test DF $8 \ldots . .70$

54 Disc E'ilter Vessel Pressure During Disc filter Test DF $8 \ldots \ldots \ldots 71$

55 Rressure Drop, Flow Rate, and Face Velocity During

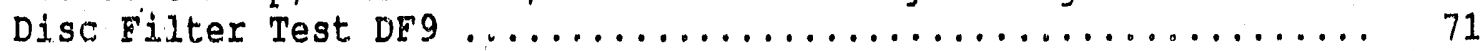

56 Disc Filter Outlet Temperature During Disc Filter Test DF9 .... 72

57 Disc Filter Vessel Pressure During Disc Filter Test DF9 ...... 72

58 Presgure Drop, Flow Rate, and Face Velocity During Disc Filter Test DF'10 ........................ 73

59 Disc Fil.ter Outlet Temperature During DisC Filter Test DF10 ... 73

60 Disc Filter Vessel Pressure During Disc Filter Test DF10 ..... 74

61 Pressure Drop, Flow Rate, and Face Velocity During Disc Filter Test DF11 ........................... 74

62 Disc Filter Outlet Temperature During Disc Filter Test DF11 ... 75

63 Disc Filter Vessel Pressure During Disc Filter Test DF12 ..... 75

64 Effect of Face Velocity on Pressure Drop Through Disc Filter and Dust Cake for Disc Filter Test DF1 ............ 80

¿5 Effect of Face Velocity on $k_{2}$ for Disc Filter Test DF1 ...... 80

66 Effect of Face Velocity on Pressure Drop Through Disc

67 Effect of Face Velocity on $K_{2}$ for Disc Filter Test DF2 ...... 81 


\section{IIST OT FIGURES}

(Continued)

Fiqure

Page

68 Effect of Face Velocity on Pressure Drop Through Disc

Filter and Dust Cake for Disc Filter Test DF3 ............. 82

69

Effect of Face Velocity on $k_{2}$ for Disc Filter Test DF3

82

70 Effect of Face Velocity on Pressure Drop Through Disc

Filter and Dust Cake for Disc Filter Test DF4 ............ 83

71 Effect of Face Velocity on $k_{2}$ for Disc Filter Test DF $4 \ldots \ldots \ldots$

72 Effect of Face Velocity on Pressure Drop Through Disc

Filter, and Dust Cake for Disc Filter Test DF5

Effect of Face Valocity on $\mathrm{K}_{2}$ for Disc Filter Test DF5

74 Effect of Eace Velocity on Pressure Drop Through Disc

Filter and Dust Cake for Disc Filter Test DF6

Effect of race Velocity on $K_{2}$ for Disc Filter Test DF $6 \ldots \ldots$..... 85

76 Effect of Face Velocity on Pressure Drop Through Disc

Filter and Dust Cake for Disc Filter Test DF7 ............ 86

Effect of Face Velocity on $k_{2}$ for Disc Filter Test DF7

78 Effect of Face Velocity on Pressure Drop Through Disc

Filter and Dust Cake for Disc Filter Test DF8

Effect of Face Velocity on $k_{2}$ for Disc Filter Test DF8 ........

80 Effect of Face Velocity on Pressure Drop Through Disc

Filtar and Dust Cake for DisC Filter Test DF $9 \ldots \ldots \ldots \ldots \ldots . . . .68$

81 Effect of Face Velocity on $k_{2}$ for Disc Filter Test DF9 ...... 88

82 Effect of Face Velocity on Pressure Drop Through Disc

Filter and Dust Cake for Disc Filter Test DF11 ............ 89

83 Effect of Eace velocity on $k_{2}$ for Disc Filter Test DF11 . . . . 89

84 SEM of CF1 Dust Cake Perpendicular to the Bedding Plane ...... 91

85 SEM of CE1 Dust Cake Parallel to the Bedding Plane .......... 91

86 SEM of CF1 Dusk Cake Perpendicular to Bedding Plane

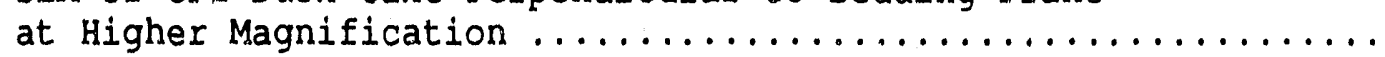




\section{LIST OF FIGURES}

(Continued)

Figure

87 SEM of CF2 Dusk Cake Perpendicular to the Bedding Plane ...... 92

88 SEM of CF3 Dust Cake Perpendicular to the Bedding Plane ....... 93

89 SEM of CF3 Dust Cake Perpendicular to Bedding Plane at Higher Magnification ......................... 93

\section{IIST OF TABLES}

$\underline{\text { Table }}$

1 Nominal Operating Conditions of the 6-Inch AFBC During the Test Series ................................. 18

2 Nominal Candle-Filter Operating Range During the Test Series .... 21

3 Nominal Disc-Filter Operating Range $\ldots \ldots \ldots \ldots \ldots \ldots \ldots \ldots \ldots \ldots \ldots$

4 Deviations From Isokinetic Sampling for the Disk Filter Test Series ................................... 23

5 Summary of Results From Candle-Filter Test Series ........... 29

6 Sumary of Particulate Grab Samples From Candle-Filter Test Series ..................................... 31

7 Summary of Results From Disc-Filter Test Series ............ 33

8. Material Removed From Cyclone System, AFBC Exhaust Cyclones, and Bed Overflow Drain .................... 45

9 Laboratory Analysis of Combustor Discharge Material, Samples R20, R15, R16, R7-6, and R17 ............... 47

10 Laboratory Analysis of Disc-Filter Dust Cakes ............. 60

11 Process Parameters When Hot Nitrogen was Passed Through the Formed Dust Cake ......................... 77

12 Laboratory Analysis of Candle-Filter Dust Cakes ........... 94

13 Laboratory Analysis of Dust Samples.................. 95 
In the spring of lyyy, two separate test series were simultaneously conducted at the U.S. Department of Energy's (DOE's) Morgantown Energy Technology Center (METC) to examine applied and fundamental behavior of dust cake filtration under high temperature and high pressure (HTHP) conditions. The purpose was to provide information on dust-cake filtration properties to gas stream cleanup researchers associated with the Tidd 70 megawatt (MW' pressurized fluidized-bed combustor (PFBC). The two test facilities included (1) a high-pressure natural-gas combustor with injected particulate, which was fed to two full-size candle filters; and (2) an atmospheric fluidized-bed combustor (AFBC) with coal and limestone sorbent to generate a particulate-laden combustion exhaust gas, which was sent to a single full-size candle filter and a small-scale disc filter. Several major conclusions from these studies are noted below.

- On average reducing the mean particulate size by $33 \%$ and the associated loading carried in the filtrate will increase the dust cake specific flow resistance $\left(K_{2}\right)$ by 4988 .

- High-temperature and high-pressure filtration can be successfully performed with ceramic candle filters at moderate filtration face velocities and reasonable system pressure drops.

- Off-line filter cleaning can produce a filter system with a higher apparent permeability than that produced with on-line filter cleaning at the same face velocity. 


\subsection{INTRODUCTION}

An experimental test campaign was conducted at the U.S. DOE'S METC. The purpose was to explore the filtration properties of dust derived from the fluidized-bed combustion of coal. Results from the investigation address near-term design issues related to HTHP particulate filtration tests to be conducted at the Tidd $70 \mathrm{MP}$ PFBC in Brililiant, Ohio.

Since the DOE is supporting a demonstration test period at the Tidd PFBC, fundamental and process design questions concerning PFBC particulate filtration and the behavior of dust cakes must be answered. Answering these questions means that the particulate cleanup equipment envisioned for the Tidd facility can be selected, tesigned, and installed within an appropriate time fxame. In addition, the ancillary equipment (cyclones) and operational/design guidelines (face velocity, pressure drop, cleaning cycles, particle concentration, size distribution, and filter porosity) must be specified so that the most amenable dust cake can be formed. This test campaign attempts to provide information that may be used to answer some of these questions.

Two different test facilities were designed and constructed. Each facility emphasized different aspects of dust cake filtration in a EFBC application. This approach was taken since METC is not equipped with a PFBC that could simulate the exact filtration conditions expected at the Tidd PFBC. The two separate test facilities consisted of (1) a high-pressure natural-gas combustor with injected and entrained particulate, which was fed to two fullsize candle filters (Zeh, Chiang, and Ayers May 1990); and (2) an atmospheric fluidized-bed combustor using coal and limestone sorbent to generate a particulate-laden exhaust gas, which was sent to a single full-size candle filter and a small-scale disc filter. The effects of pressure, cleaning techniques, and face velocity on dust-cake filtration properties were explored with the pressurized natural-gas combustion. The effects of particulate size distribution, face velocity, and cake thickness on dust cake filtration were studied with the AFBC test facility. This report describes the AFBC particulate test facility and the results from the test sexies.

The overall objective of these tests was to provide Tidd PFBC gasstream-cleanup researchers with operational and design guidelines that could be implemented prior to and during the demonstration test period scheduled for January 1992. Specific issues addressed in this investigation include (1) the effect of particulate size distribution on specific flow resistance $\left(K_{2}\right)$ in a dust cake filtration application, and (2) the effect oi filter face velocity and cake thicknioss on $k_{2}$. 


\subsection{EXPERIMENTAL APPROACH}

Fundamental and applied filtering phenomena as they might occur under Tidd PFBC conditions were studied. The tests were conducted in order to evaluate the effects of various operating parameters on HTHP barrier-filter dust-cake filtration. A 6-inch inside diameter AFBC was designed and built to provide a particulate-laden gas stream. A portion of the effiuent from this combustor was fed to two filtering vessels: one housed a full-size ceramic candle filter, the other held a 4.25-inch ceramic disc filter. Mean particle size was varied with cyclones in the full-size candle filter tests, and the effects on dust cake filtration were evaluated. The disc filter was used to study fundamental aspects of dust cake filtration where particle size, dust cake thickness, and face velocity were varied. A conventional experimental approach was used for the full-size candle-filter test series; the work of Leith and Allar (1986) was used to analyze the effect of particle size on $K_{2}$. The approach used in the disc filter tests was similar to that in the studies by Holland and Rothwell (Holland and Rothwell 1977a, 1977b; Rothwell 1985).

The AFBC tests were not conducted at high pressure because it was believed that certain dust-cake filtration phenomena at high pressure could be studied at low pressure. In addition, since particulate size distribution and morphology play a large role in dust cake filtration, it was decided to use an $A F B C$ as the particulate source, rather than using simulated or re-entrained particles. 


\subsection{EXPERTUTHMAL TEST FACILITY}

To study dust cake filtration phenomena, an AFBC with an instide diameter (ID) of 6 inches was used to generate a particulate-laden gas stream. In an attempt to simulate the particulate that may be derived from the Tidd PFBC, a similar fuel and sorbent were used as the reactants in this combustor. Pittsburgh No. 8 coal, ground to a 12 by 10 mesh size, was fed to the combustor at a rate of $10 \mathrm{lb} / \mathrm{h}$, and Greer limestone, ground to 12 by 0 mesh, was used as the sulfur sorbent and fed at a rate of $1.5 \mathrm{ib} / \mathrm{h}$. These fuel and sorbent feed rates provided a calcium to sulfur molar ratio of $1.6: 1$. The 6 -in. AFBC provided a particulate-laden process stream to both a full-size candle filter at a nominal flow rate of $1,200 \mathrm{scf} / \mathrm{h}$, and to a ceramic disc filter with an active filter area of $14.2 \mathrm{in}^{2}$ at a nominal flow rate of $65 \mathrm{scf} / \mathrm{h}$. Approximately one half of the effluent from the combustor was sampled to provide the particulate-laden gas stream; the remaining exhaust was vented to the atmosphere. Gases transported from the combustor to the filter vessels were guard-heated and carried in 1-in. tubing. Figure 1 is a schematic layout of the filtering vessels and combustor test facility, and Figure 2 shows a simplified process and instrumentation diagram.

\subsection{Description of the 6-Inch Atmospharic Fluidized-Bed Combustor}

A 14-in. Schedule 40, carbon steel vessel was used to house a 6-in. ID AFBC. A schematic of this vessel is shown in Figure 3. The combustor was designed with an internal bed temperature of $1,600^{\circ} \mathrm{F}$ and a nominal operating pressure of $35 \mathrm{psig.} \mathrm{Operating} \mathrm{at} 1$ to 2 atm provided enough system pressure to drive the particulate-laden gas stream through the two downstream filter vessels, associated piping, and flow sontrol loops.

Two linings of a castable refractory were poured in the combustor bed section to provide a vessel skin temperature under $500{ }^{\circ} \mathrm{F}$ and a wearresistant inner combustor surface. One layer of refractory was used in the freeboard. Plibrico HyRezist was used as the inner wear-resistant layer with a thermal conductivity of $7.5 \mathrm{~J}, \mathrm{cu}$ in $/ \mathrm{h} \mathrm{ft}^{2}{ }^{\circ} \mathrm{F}$ at $1,500^{\circ} \mathrm{F}$, and Plibrico LWI-20 was used as the insulating outer layer with a thermal conductivity of $1.7 \mathrm{Btu}$ in/h $\mathrm{ft}^{2}{ }^{\circ} \mathrm{F}$ at $1,500^{\circ} \mathrm{F}$. The internal combustor dimensions were a 6-in. diameter by 4-ft long section, a 1-ft transition section, and a 9-in. diameter by $4-f t$ long freeboard.

Fluidizing air was injected into a refractory-lined combustor plenum and allowed to flow through a conical distributor plate. The distributor plate cone had a $90^{\circ}$ included angle and 180 holes drilled open to a $0.062-i n$. diameter. The distributor plate holes were staggered and drilled on six concentric circles, providing an open area of approximately $2 \%$. A $0.5-i n$. central fluidizing jet was located at the apex of the cone. Flow rates of the main fluidizing air and the fluidizing jet were independently controlled and rated at 1,000 to $5,000 \mathrm{~s}: \mathrm{f} / \mathrm{h}$ and 500 to $1,500 \mathrm{scf} / \mathrm{h}$, respectively. Providing separate and variable flow configurations allowed flexibility in operation and various modes of fluidization to be obtained (i.e., bubbling, slugging, or spouted). 


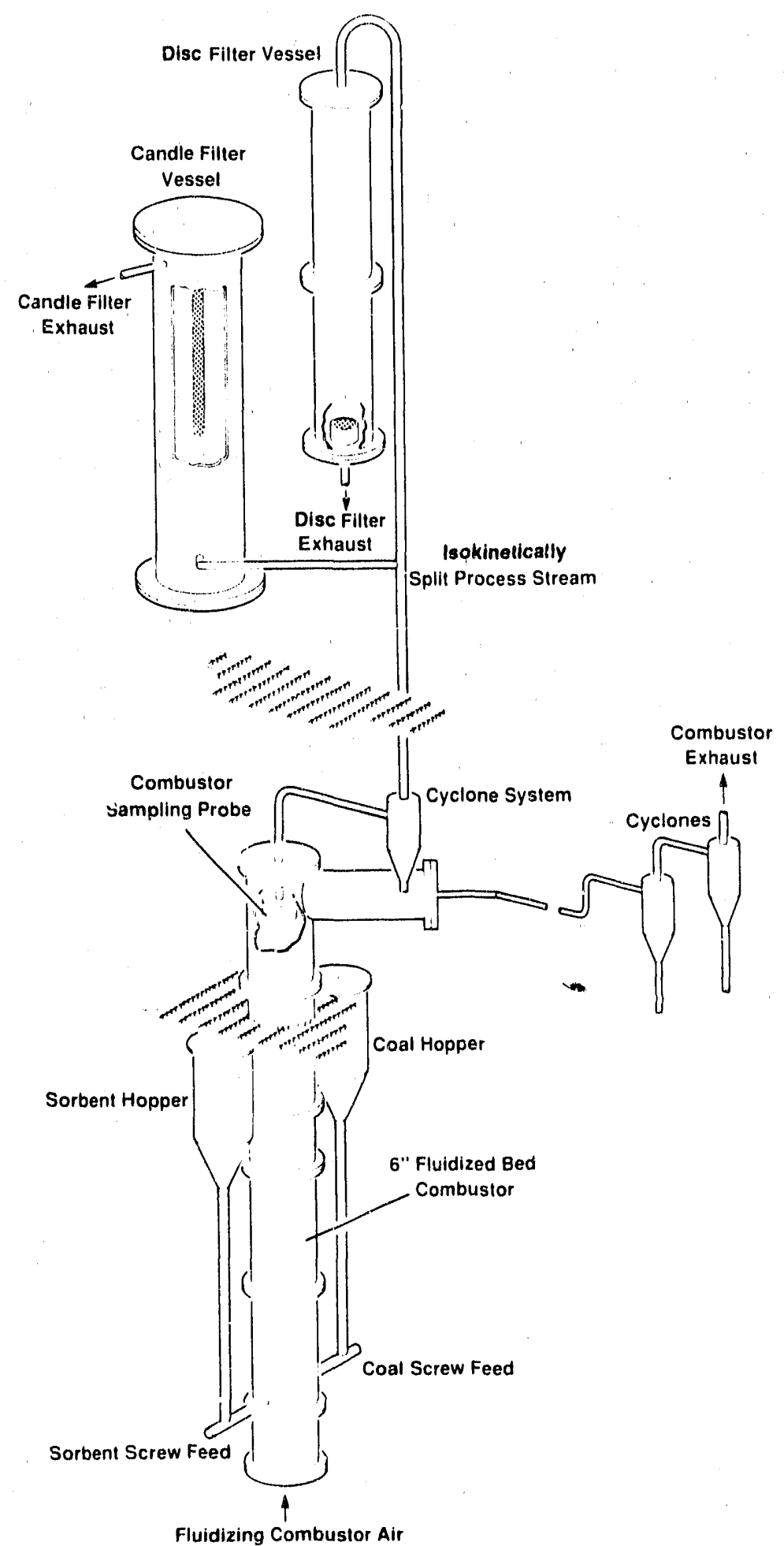

$M 91000884$

Figure 1. Conceptual Schematic of the AFBC Particulate-Cleanup Test racility 


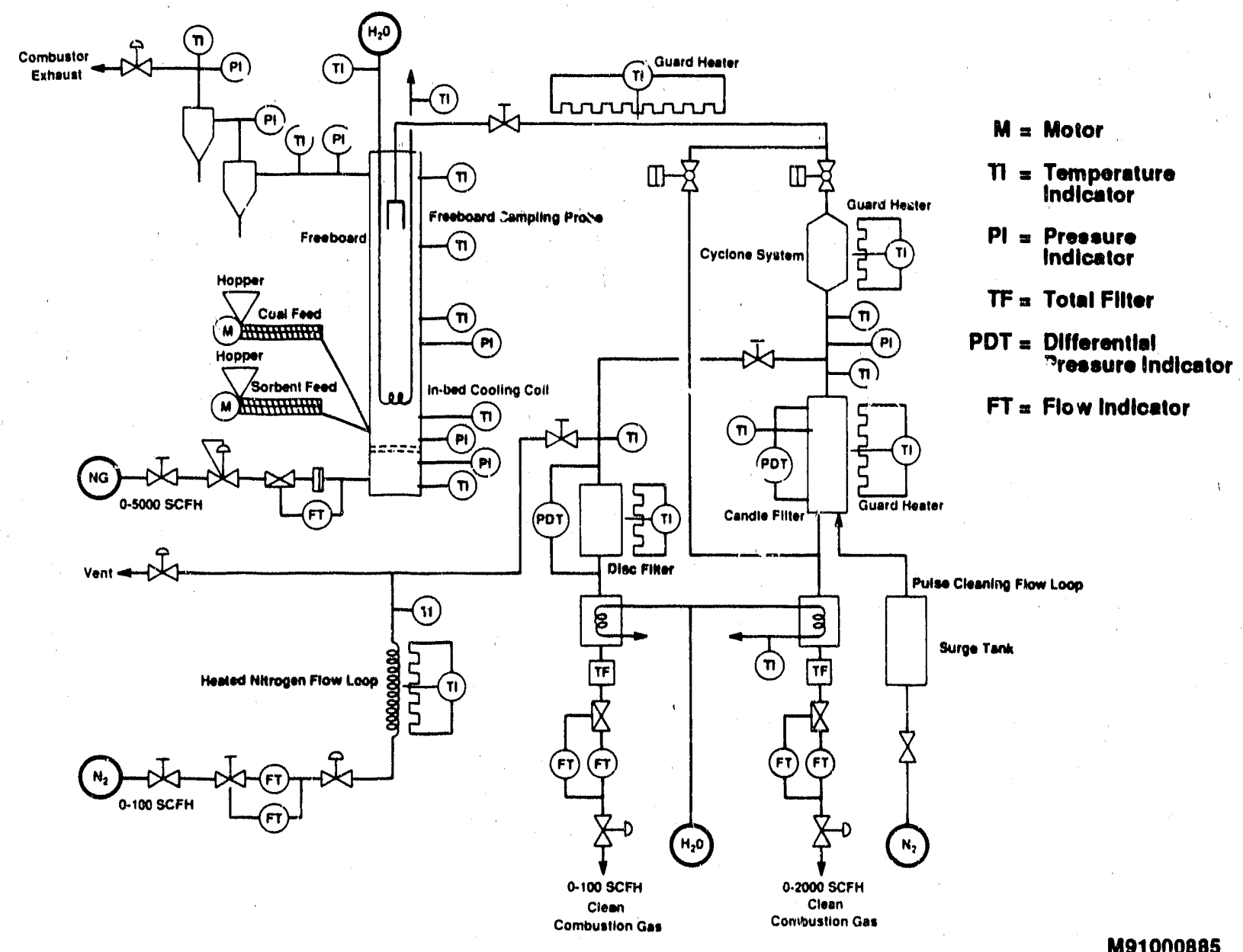

Tigure 2. Simplified Process Flow and Instrumentation Diagram of the ArBC Particulate-Cleanup Test racility

Fuel and sorbent were fed through the wall of the combustor 2 inches above the distributor plate. The penetrations for the two feed systems were $180^{\circ}$ apart. Both material feed systems were pressure balanced to the combustor. To accomplish this, impulse lines were run from a central surge tank to the respective material lockhoppers and from the surge tank to the combustor freeboard. The screw feed systems were water cooled. Nitrogen was injected down the central screw-driven material conveying passage, and also through eight concentric 0.062-in. diameter holes at the end of the feeder. Overflow drains were provided at four elevations $(9.5,12.5,15.5$, and 21.5 in.), permitting flexibility in selecting a desired bed height.

Particulate-laden gas from the combustor was discharged in two separate flow legs. The main combustor exhaust consisted of a primary and a secondary cyclone, a total filter, a back-pressure control valve, and an exhaust plenum. 


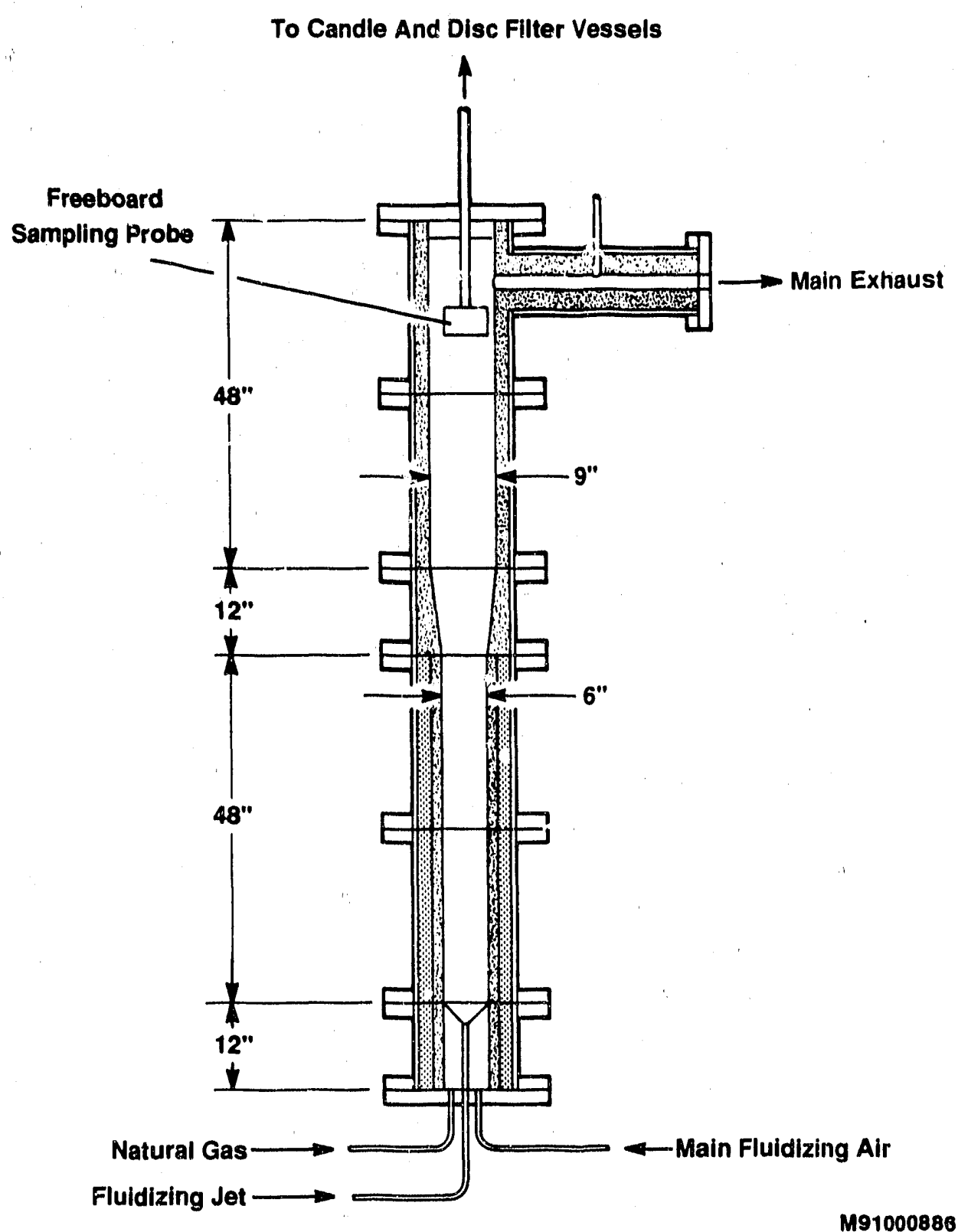

Tigure 3. Schematic of 6-Inch ATBC Vessel

The back-pressure control valve was used to maintain a desired combustor operating pressure. The second exhaust leg was used to provide the particulateladen gas stream to the filter vessels. This flow was sampled in the combustor freeboard through a 6 -in. long section of 5 -in. Schedule 40 , carbon steel pipe. The closed end of this sampling canistex was attached to a $1-i n$. stainless steel tube, which conveyed the gas out of the combustor. The inlet to the sampling can was positioned in the freeboard 7 feet above the combustor distributor plate. Combustor pressure forced flow through this sample line. 
The flow was controlled by back-pressure flow-control systems on the downstream side of the candle and disc filter vessels.

Combustor temperatures were measured at elevations of $3.0,6.0,9.0$, $12.0,36.0,63.0$, and $96.0 \mathrm{in}$. above the distributor plate. Pressure drop measurements were made across the distributor plate and across several bed heights. To help moderate combustion temperatures, an in-bed cooling coil was provided. The coil was fabricated from $0.375 \times 0.035$ in. wall thickness, 304 stainless steel (ss) tubing with 10 wraps on a $3.5-i n$. ID. This provided $1.0 \mathrm{ft}^{2}$ of heat transfer area. The position of the coil within the bed was varied. Depending on the position of the in-bed cooling coil, water flow rates were typically between 40 and $60 \mathrm{gal} / \mathrm{h}$.

\subsection{Description of the Candle rilter Vessel}

The components of the candle filter vessel consisted of the vessel enclosure, guard-heating system, filter tubesheet assembly, laser-based dust-cake thickness-detection system, and the filter blow-back cleaning system. The vessel enclosure, shown in Figure 4, consists of a 20-in. Schedule 40, carbon steel pipe; a blind and slip-on flange provided the closure on each end. The vessel length from flange face to flange face was $70 \mathrm{in}$. The ressel was lined with Plibrico Airlite castable insulation $\left(1.0 \mathrm{Btu}\right.$ in $/ \mathrm{h} \mathrm{ft}^{\frac{2}{2}}$ at $\left.1,500^{\circ} \mathrm{F}\right)$ to form a 9-in. ID. The insulating liner began in the center of the top support ring 10.25 in. below the top of the raised face flange and extended for 48 in. A 4-in. thick shelf of insulation was located 22 in. below the top surface of the insulation; the shelf was cast in place, reducing the ID to 6 in. This shelf served to support the top zone of the vessel's guard heaters. The cast refractory extended $22 \mathrm{in}$. below the 4 -in. shelf to the center of the bottom support ring.

Four sight-glass penetrations were made through the shelf. Penetrations for the sight glasses were made every $90^{\circ}$, with one line of sight directly through the center of the vessel and the second slightly of the center axis (approximately $1.18 \mathrm{in.)}$. The off-axis penetration was made to view the tangential surface of the candle filter. The off-axis set of windows provided access for the dust cake thickness detection system, which is described below.

Guard heating in the candle filter vessel was required to maintain the internal cavity of the vessel at the desired operating temperature of $1,500^{\circ} \mathrm{F}$. This heating system consisted of two separate zones that were individually controlled with variable transformers. Each zone contained two half-section heating units (Thermcraft, Inc., Model RL 194) that formed a complete cylinder when positioned in the vessel. When in the cylindrical configuration, the ID was $7 \mathrm{in.,}$ the outside diameter (OD) was $8.5 \mathrm{in.}$, and the length was $18 \mathrm{in}$. Each zone had a recommended maximum temperature of $1,850{ }^{\circ} \mathrm{F}$ with a power output of 5,640 W. The upper and lower heating zones were separated by the 4-in. thick shelf, which supported the upper heating cylinder and permitted optical access to the filter element. A shroud was positioned between the heaters and the filter; the shroud was fabricated from a 5-in. 


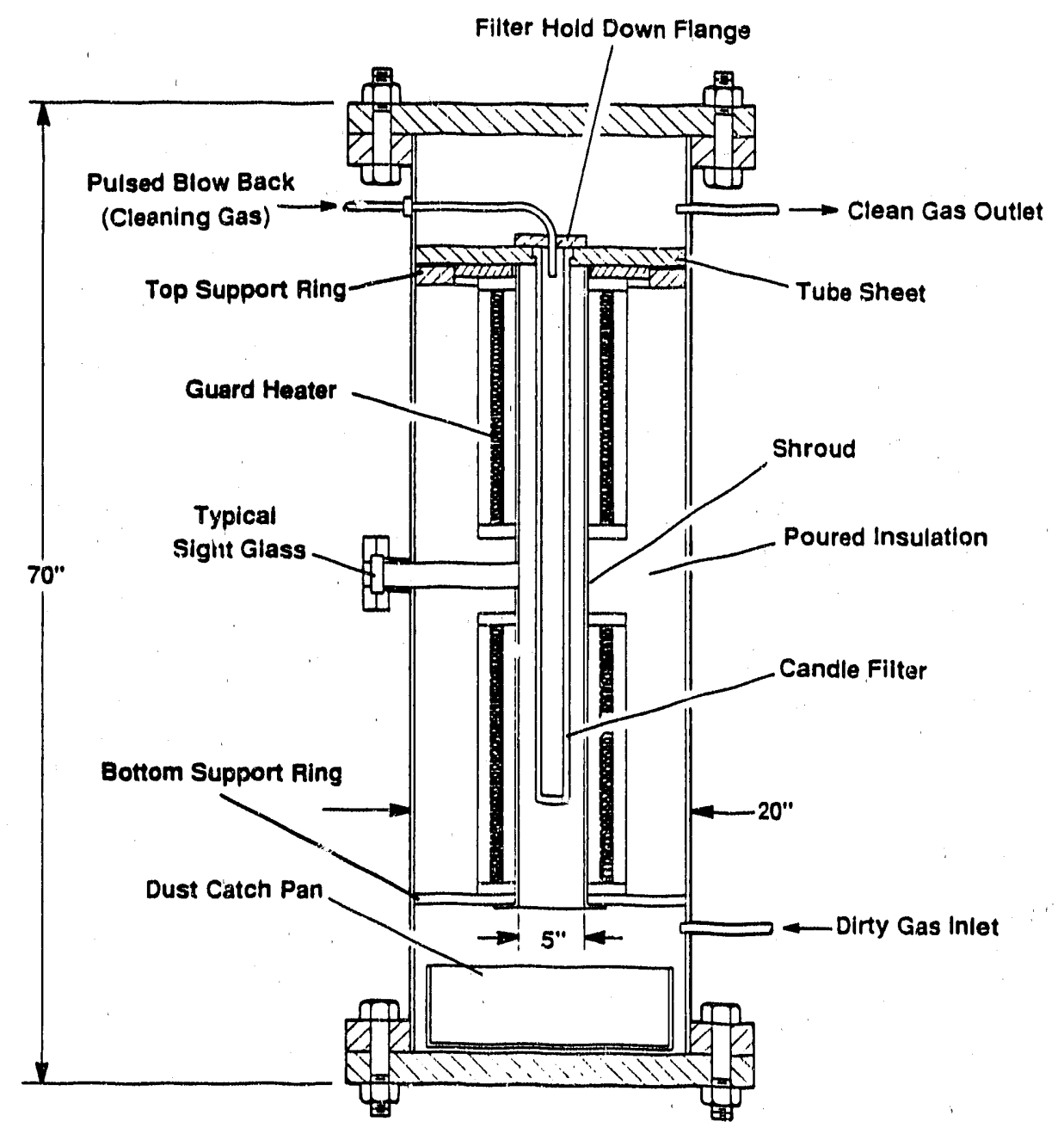

M91000887

rigure 4. Schematic of Candle Pilter Vessel

Schedule 10 , ss pipe. The shroud was flanged and supported by the bottom support ring. The purpose of the shroud was to prevent dust from contaminating the heating elements and to permit more uniform heating of the candle filter.

For all of the tests, the same Refractron Corp. RI-20 candle filter was used. The dimensions and configuration of the filter are shown in Figure 5. Silicon carbide was used to fabricate the filter; the silicon carbide was isostatically pressed to the basic shape and then was machined to the final dimensions. The flange and bottom cap of the filter were glued in place. The mean and large pore sizes for this filter composition were measured by an American Society for Testing and Materials (ASTM) bubble test to be 43 and 
$77 \mu \mathrm{m}$, respectively. ${ }^{2}$ The slope for pressure drop versus face velocity was determined to be 0.7 in $\mathrm{H}_{2} \mathrm{O} \mathrm{min} / \mathrm{ft}$ for air at ambient conditions. ${ }^{1,2} \mathrm{~A}$ maximum working temperature of $1,800^{\circ} \mathrm{F}$ and a room-temperature modulus of rupture of about 1,350 psi were suggested for filters of this configuration and material.

The filter tubesheet assembly shown in Figure 6 consists of a tubesheet disc, filter gasketing material, and a hold-down flange, The tubesheet disc, which was supported on the top support ring, was fabricated from 304 ss with a Finished thickness of 1.5 in. Graph-lock gasketing material was used to maintain the pressure seal between the tubesheet and the top support ring. The dimensions and tolerance for the candle-filter tubesheet interface were taken from Institute of Gas Technology (IGT) specifications (1987)! The holddown flange shown in the IGT specifications was not used in this assembly because of the high-pressure drop associated with the design. A new hold-down flange (shown in Figure 6) was employed that lowered the restriction on the exiting filtered gas stream.

Even though the new hold-down flange was designed with a lower pressure drop, the gasketing techniqua and tolerances remained the same. Three gaskets were used: (1) an Interam I-10 (3M Company) was used at the filter flange tubesheet interface, (2) an Interam $I-10$ was used at the hold-down flange filter-flange interface, and (3) a metal 0-ring gasket was used at the tubesheet hold-down flange interface. The first gasket was the only required pressure seal; the second Interam gasket was required to account for the differerice in thermal expansion between the metal flange, the tubesheet, and the cEramic filter. The metal 0-ring gasket was an IGT design and was only required if multiple candle filters were used with the exiting gas stream being separately controlled through dedicated manifolds.

The laser-based detection system for dust-cake thickness (Figure 7) was developed to measure the build-up of dust on the candle filter. In principle, the operation of this device relies on converting an obstructed laser beam into a proportional current. As the dust is filtered and a dust cake builds up, the laser beam is attenuated or blocked, which proportionally reduces the current produced by a light-receiving photo diode.

To help improve the linearity of the device, a mask was used to form a square beam from the center of a normally circular collimated laser beam. such a beam has a more constant intensity because of the Gaussian intensity distribution of the original beam. The light was also split into two parallel beams of equal intensity, with one beam serving as a reference. The reference beam accounted for any attenuation or blockage caused by the access windows or internal and external airborne dust. During the signal processing, the ratio

1 P. Eggerstedt, Industrial Filter and Pump Manufacturing Company. January 20, 1989. Personal Communication with $\mathrm{K}$. Pater, METC.

2 P. Eggerstedt, Industrial Filter and Pump Manufacturing Company. October 2, 1989. Personal Communication with C. Zeh, METC. 

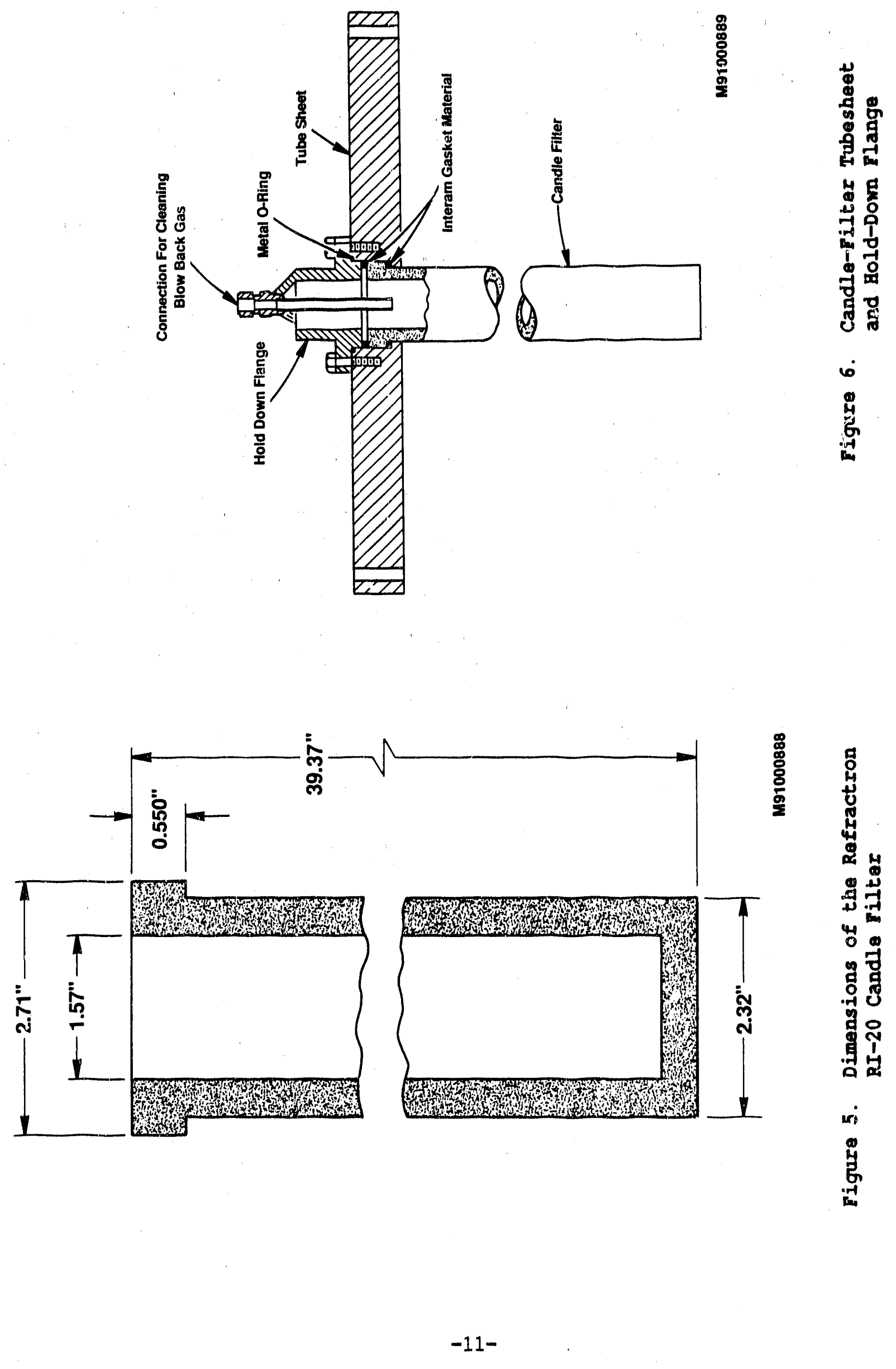


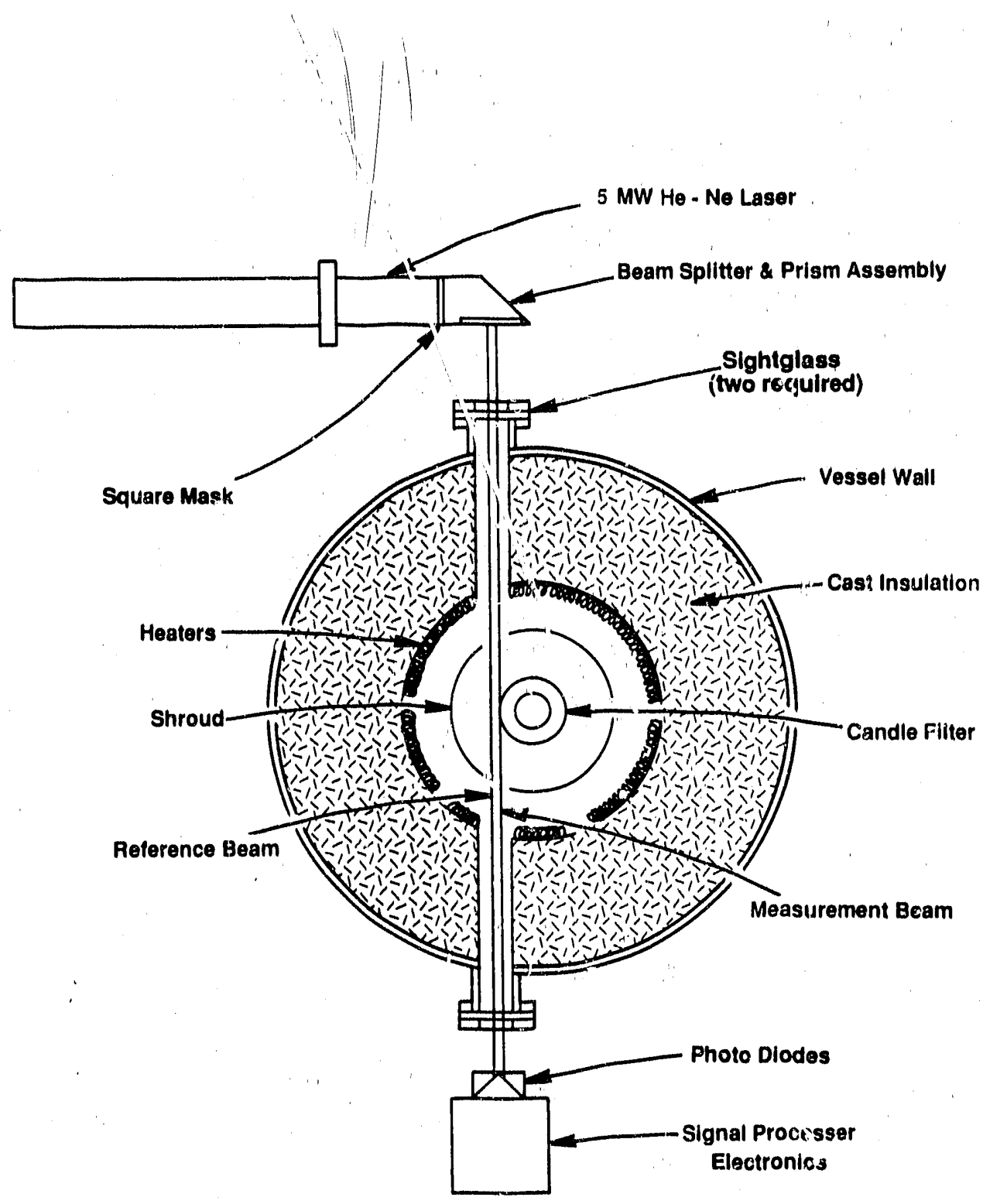

$M 91000890$

\section{rigure 7. Candle-rilter Dust-Cake-Thickness Detector}

of the generated current from both beams was measured and was calibrated to be proportional to the amount the measurement beam was blocked.

The candle-filter blow-back system consisted of a reservoir tank, switching valve, solenoid valve, pulse timers, and associated tubing. The purpose of the blow-back system was to clean the candle filter with a short pulse of nitrogen. Enough nitrogen is needed to reverse the flow of the filtrate and to remove the collected dust cake. The pulse of nitrogen should be large and fast enough so that cleaning is uniform along the length of the candle. Overpressuring the filter during a cleaning cycle could result in the shattering of the dust cake as it is removed, resulting in dust re-entrainment prior to settling.

The blow-back system reservoir-tank provided a volume of $2.3 \mathrm{ft}^{3}$, with the pressure regulated to $225 \mathrm{psig}$ from a 600 psig nitrogen source. The 
solenoid was connected to the reservoir tank by 59 in. of half-inch ss tubing with a wall thickness of 0.035 in. A switching valve was located approximately 6 in. from the solenoid valve. The purpose of the switchin, valve was to direct the pulsed nitrogen to either the candle or disc filter. From the switching valve, $35 \mathrm{in}$. of $0.5 \mathrm{in.} \mathrm{ss}$ tubing ran to just inside the candle filter vessel. The final connection from inside the vessel to the $0.375 \mathrm{in}$. tube on the top of the hold-down rlange was made with a 10 in. long, 0.5 in. flexible metal hose.

Two timers connected in series controlled the duration, frequency, and composition of the blow-back pulse train leaving the solenoid valve ard entering the candle filter vessel. One timer controlled the frequency and length of each pulse train delivered, while the second controlled the composition. For instance, a pulse train could be delivered every hrur for 5 seconds (frequency and length), with a 1-secort pulse on, followed iy a 1-second pulse off, repeating for 5 seconds (composition).

\subsection{Description of the Dise Filter Vessel}

This vessel consisted of the vessel enclosure, guard-heating system, and a disc-fiiter support assemtly. The disc filter vessel shown in Figure 8 was assembled from two spool pieces of flanged 12-in. Schedule 40, carbon steel pipe. The overall height of the assembled spool pieces was 75 in. Support rings were welded in place towards the bottom of each spool piece to support the guard heaters. Several penetrations were made through the vessel wall to accommodate guard-heater temperature measurements. At the bottom of the vessel, the filter stage flange was mounted to a machined-open 12-in. blind flange, which supported the disc filter holder.

Three cylindrical sections of guard heaters were provided in the vessel to maintain the desired operating temperature. Two cylindrical sections were positioned in the upper-flow development cavity, and one cylindrical section was located where the disc filter was positioned. Each of the two upper cylindrical sections was fabricated from two heating elements (Thermcraft, Inc., RL 184) with a 6-in. ID, a 7.5-in. OD, and a length of $24 \mathrm{in}$. The maximum recommended temperature for these heating elements was $1,850{ }^{\circ} \mathrm{F}$, with a total power output of $13.6 \mathrm{~kW}$ for these two cylindrical sections.

The third set of guard-heating elements was positioned in the bottom portion of the vessel to provide guard heat to the disc filter holder. These two half-cylinders were fabricated from heating elements (Thermcraft, Inc., RL 181) with a 6 in. ID, a 7.5-in. OD, and a length of 6 in. The total power output of this cylindrical section was $2.3 \mathrm{kw}$. The maximum recommended operating temperature for these elements was also $1,850^{\circ} \mathrm{F}$.

Blanket-type insulation (Durablanket $\mathrm{HD}$, by Carborundum Co.) was used in the two spool pieces. Two layers of this insulation were wrapped around each set of heating elements before being slipped into the vessel cavity. Fiber board insulation was used on the disc-filter holder assembly (Duraboard HD, by Carborundum Co.l, formed into doughnut shapes, stacked, and cemented in place. 


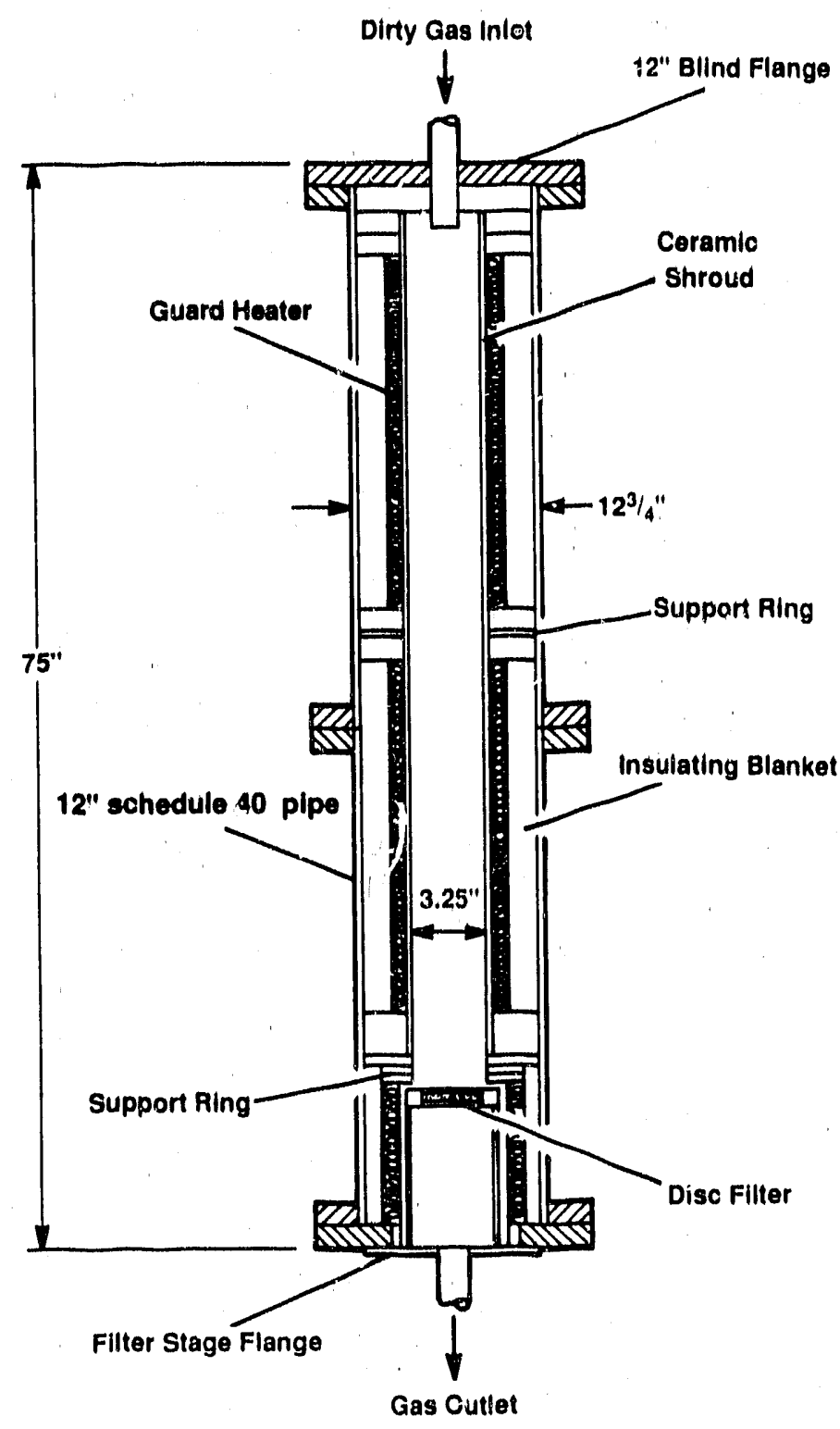

M91000891

rigure 8. Schematic of Disc rilter Vessel

Each heating zone was independently controlled with continuously variable power transformers.

A shroud fabricated from a 60 in. length of 4 -in. Schedule 10 , ss pipe was placed in the flow cavity of the disc filter vessel. The shroud prevented dust from settling on the heating elements and provided for more uniform heating along the length of the flow cavity. The shroud was flanged on one end and was mounted to the bottom of the lower support ring.

A disc filter holder (Figure 9) was used to mount the disc filter in the vessel and to form the pressure seal between the clean and dirty sides of the 


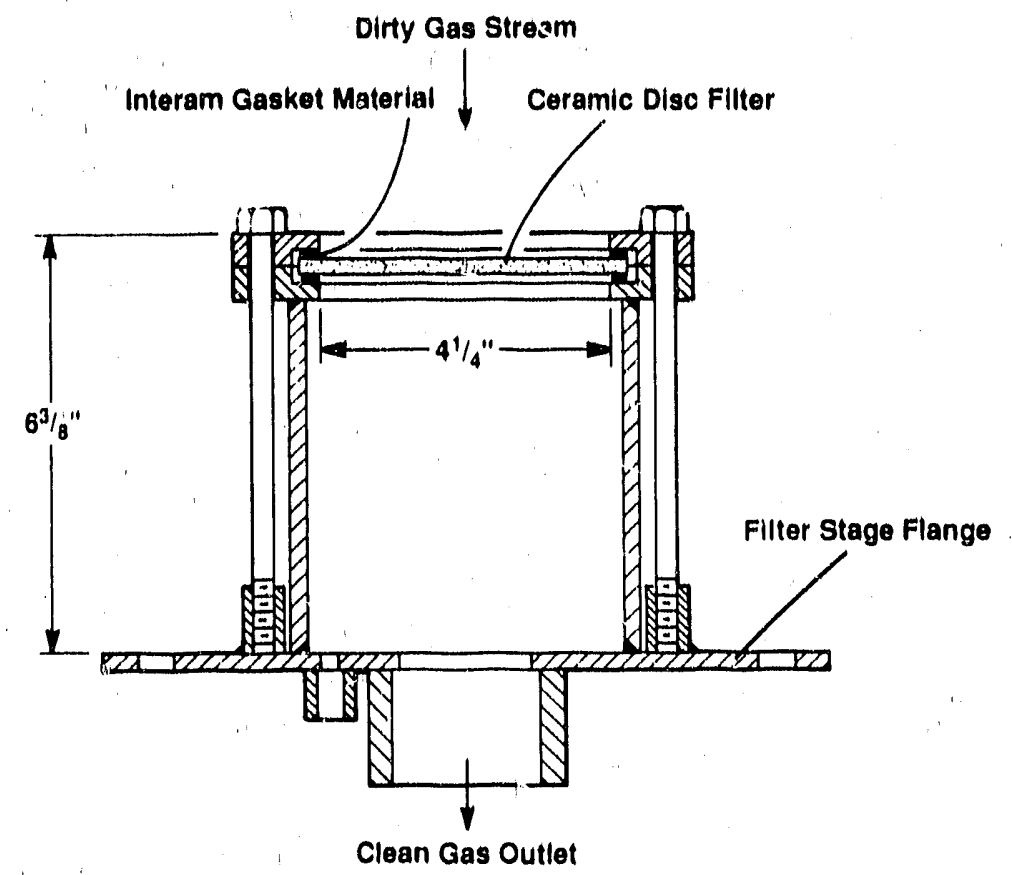

M91000892

rigure 9. Schematic of Disc rilter Holder

filter. Interam I-10 was used as the gasketing material on both sides of the disc filter. The holder was fabricated from 304 ss to withstand the hot and cold cyclic service conditions. The stud bolts for the assembly were threaded to bolt holes, which were centered on a ring attached to the filter stage flange. This design allowed the threaded connections to operate at a lower temperature, thus preventing galling and seizure.

\subsection{Description of the Cyclone System}

The cyclone system consisted of three cyclonic separation devices with designed $d_{50}$ cut sizes of $2.3 \mu \mathrm{m}$ (cyclone 1 ), $1.5 \mu \mathrm{m}$ (cyclone 2 ), and $0.8 \mu \mathrm{m}$ (cyclone 3). Respective inlet design velocities were 30,54 , and $121 \mathrm{ft} / \mathrm{s}$. The purpose of this system was to modify the particulats size distribution prior to the candle and disc filter vessels. Standard guidelines were used to design tlie inlet areas, internal diameters, and exit diameters of the cyclones, but modifications were used to simplify the fabrication process. These modifications resulted in circular inlet cross-sections instead of the typical rectangular inlet cross-sections. The typical conical transitions were modified and resulted in straight outlets to the bottom solids exit. The three cyclones were fabricated from $304 \mathrm{ss}$ pipe, tubing, and $125 \mathrm{lb}$ flanges. Any combination of the three cyclones could be used within the cyclone system. The enclosure holding the three vessels was guard-heated to maintain the temperature of the sampled process stream. 


\subsection{Gas Stream Sampling With the Diso Filter Vessel}

In order to compare filtration results obtained from the candle and disc filters, each filter required similar particulate size distributions and particulate loadings. To accomplish this, an isokinetic sampling probe was utilized. Figures 10 and 11 show the basic layout of the sampling probe. A $0.25-i n$. ss tube (ID drilled open to $0.187 \mathrm{in.)}$ was slipped through the run length of a 1.0-in. ss tee-fitting, which sampled the gas and particulate to be sent to the disc filter. The $0.25-i n$. tube was flanged and welded to a 1.0-in. ss tube, which was held in the tee-fitting at the exit end, supplying gas to the disc filter. The other end of the tube extended through the tee, $5.375 \mathrm{in}$. into a $0.25-\mathrm{in}$. ss tube that was flared to the inlet end of the tee. The three positioning legs were used to center the $0.25-\mathrm{in}$. tube in the 1.0-in. tube. The gas stream was sampled $5.375 \mathrm{in}$. past the inlet to the tee.

The probe was designed to automatically sample isokinetically when both filters were operated at the same temperature, pressure, and filter face velocity. This principle of cparation was possible since the volumetric flow rates through each vessel were independently controlled and the ratio of the inside area of the drilled-out $0.25-i n$. tube to the inside area of the $1.0-i n$. tube was equal to the ratio of the active disc filter area to the active candle filter area. The inherent problem with this approach was that the pressure drops between the sampling probe and filters were different, as were the pressure drops in the flow control legs between the filters and the atmosphere. While this made it difficult to maintain equal pressures in the two vessels, the error imparted to the isokinetic condition was not prohibitive.

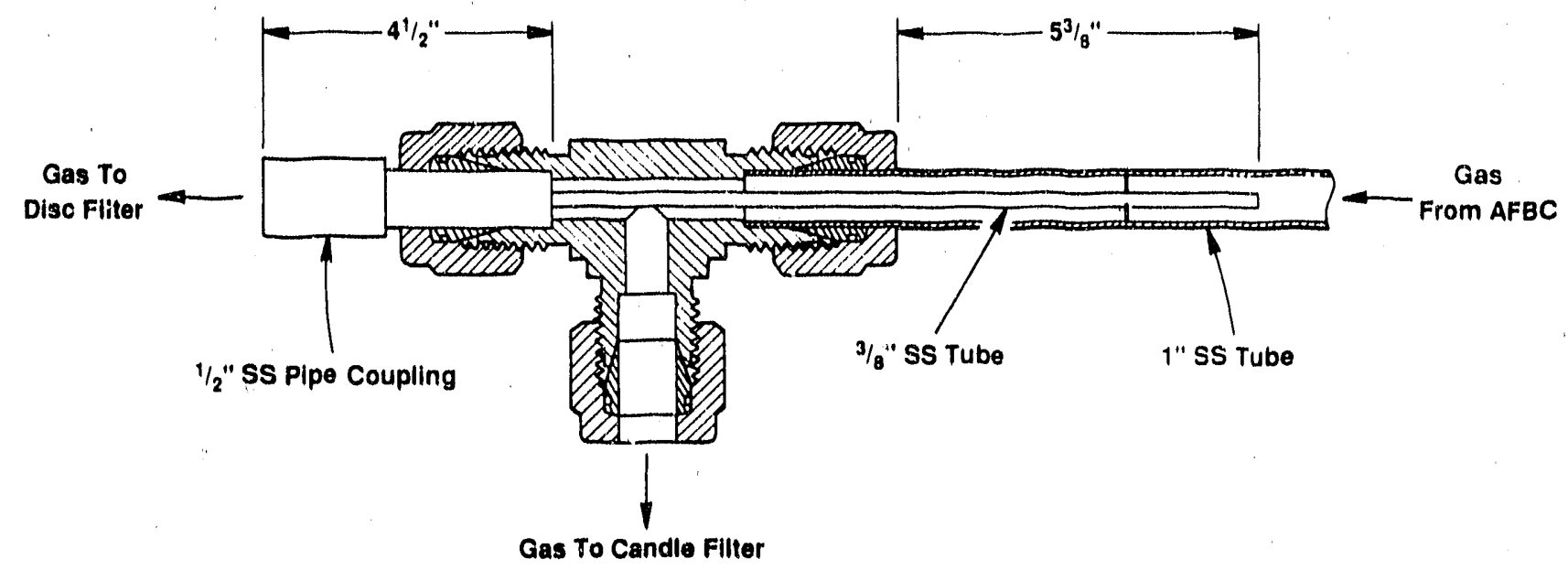

M91000893

rigure 10. Isokinetic Sampling Probe for the Disc Filter 


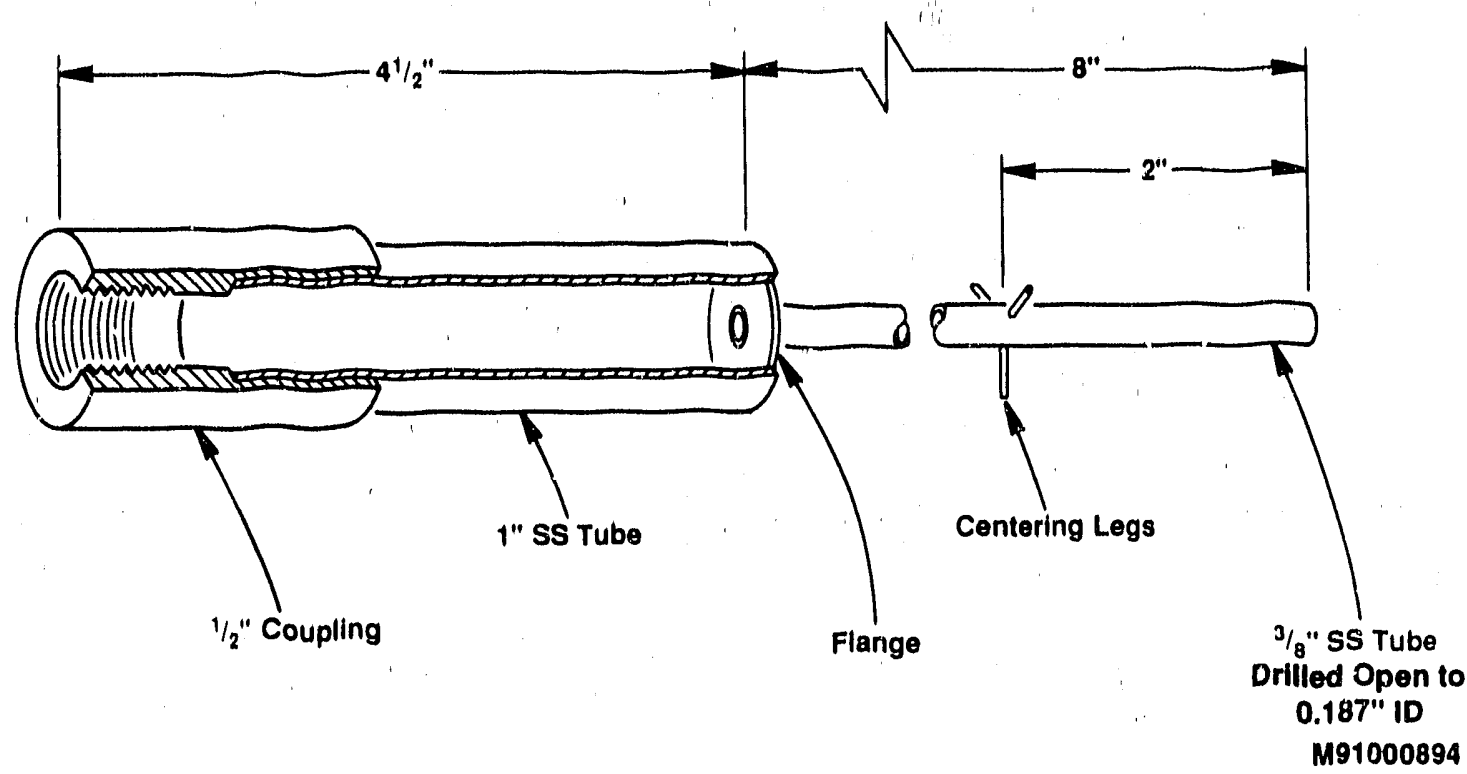

Tigure 11. Insert for the Isokinetic Sampling Probe 


\subsection{CHARACITRISTIC̈S AND ORERATION OF THE TEST FACILITY}

This discussion includes a description of the general operation of the facility as well as performance traits that may have affected the interpretation of results or test conditions. A test facility shakedown period was held prior to the actual testing, and some hardware and procedural modifications were made. However, this discussion is mostly on the operational conditions and facility changes made during the test series.

\subsection{Operational Characteristics of the Atmospheric Fluidized-Bed Combustor}

Preheating the combustor began with 5,000 $\mathrm{g}$ of sand for bed material. The sand was used to provide a thermal mass, a flame arrester, and initial insulation of the screw feeders and distributor plate during preheating. Natural gas was introduced at a rate of $30 \mathrm{scf} / \mathrm{h}$ and was mixed in the plenum with $300 \mathrm{scf} / \mathrm{h}$ of air. The flame was manually lit on the top of the bubbling sand bed. With a flame established, air and natural gas inputs were increased at $a$ 10:1 ratio until $70 \mathrm{scf} / \mathrm{h}$ of gas were introduced to the combustor. Fuel fed at this rate was sufficient to uniformly preheat the combustor to the desired temperature of $1,550^{\circ} \mathrm{F}$ in approximately 4 to 5 hours. At this time, coal and sorbent were introduced to the combustor and the natural gas was shut off.

Following the light-off procedure, stable operation of the combustor was easily obtained. Table 1 lists the combustor operating conditions for all of

Table 1. Nominal Operating Conditions of the 6-Inch ATBC During the Tast Series

\begin{tabular}{c}
\hline AFBC Operating Parameter: Value \\
Pressure: 25 psig \\
Bed Temperature: $1,575{ }^{\circ} \mathrm{F}$ \\
Excess Air: 1008 \\
Coal Type: Pittsburgh No. 8 \\
Coal Size: 10.x 12 mesh \\
Sorbent: Greer Limestone Sand \\
Sorbent Size: 10 x 10 mesh \\
Coal Feed Rate: 10 lb/h \\
Sorbent Feed Rate: $1.5 \mathrm{hb} / \mathrm{h}$ \\
Ca/S Molar Ratio: $1.6: 1$ \\
Fluidizing Velocity: $5 \mathrm{ft} / \mathrm{s}$ \\
Air Flow Rate: 2,500 $\mathrm{scf} / \mathrm{h}$ \\
Bed Depth: 21 in. \\
Bed Diameter: 6 in. \\
Particulate Emission: $7,725 \mathrm{ppmw}$ \\
\hline
\end{tabular}


the tests. The basic operation methodology was to run the combustor with enough fluidizing air to provide a dirty gas stream to the filter vessels, to operate at a high enough combustor pressure to drive the gas flow to the filter vessels, and to provide enough excess combustor exhaust so that the backpressure control valve on the main combustor exhaust leg would operate within the designed range. Having sufficient exhaust gas in the main exhaust leg also prevented condensate from forming and particulate from being deposited. When the combustor was operating with an internal bed temperature of $1,575{ }^{\circ} \mathrm{F}$, the outside metal wall temperature of the vessel was typically less then $300^{\circ} \mathrm{F}$. A typical temperature profile through the combustor is shown in Figure 12 .

The high temperature drop through the bed and freeboard of nearly $1,000{ }^{\circ} \mathrm{F}$ could be considered a problem that is characteristic of a small combustor size. The high thermal conductivity of the erosive resistant insulation in the freeboard caused further problems. The low exit temperature of the combustor exhaust eventually caused problems with condensate in the main combustor exhaust flow leg, and limited the maximum temperature attainable in the candle filter vessel.

During the initial shakedown, the combustor was found to operate reliably and with a reduced likelihood of clinkering if the bed were 21 inches deep. The deeper bed also produced a higher carbon utilization. Ash overflow drainage rates were typically $550 \mathrm{~g} / \mathrm{h}$ with a standard deviation of $75 \mathrm{~g} / \mathrm{h}$. Appendix $A$ is the mass weigh-back data from the combustor bed drain port and the main combustor exhaust cyclones. Appendix $A$ also includes a typical chemical and physical analysis of these samples from the three locations.

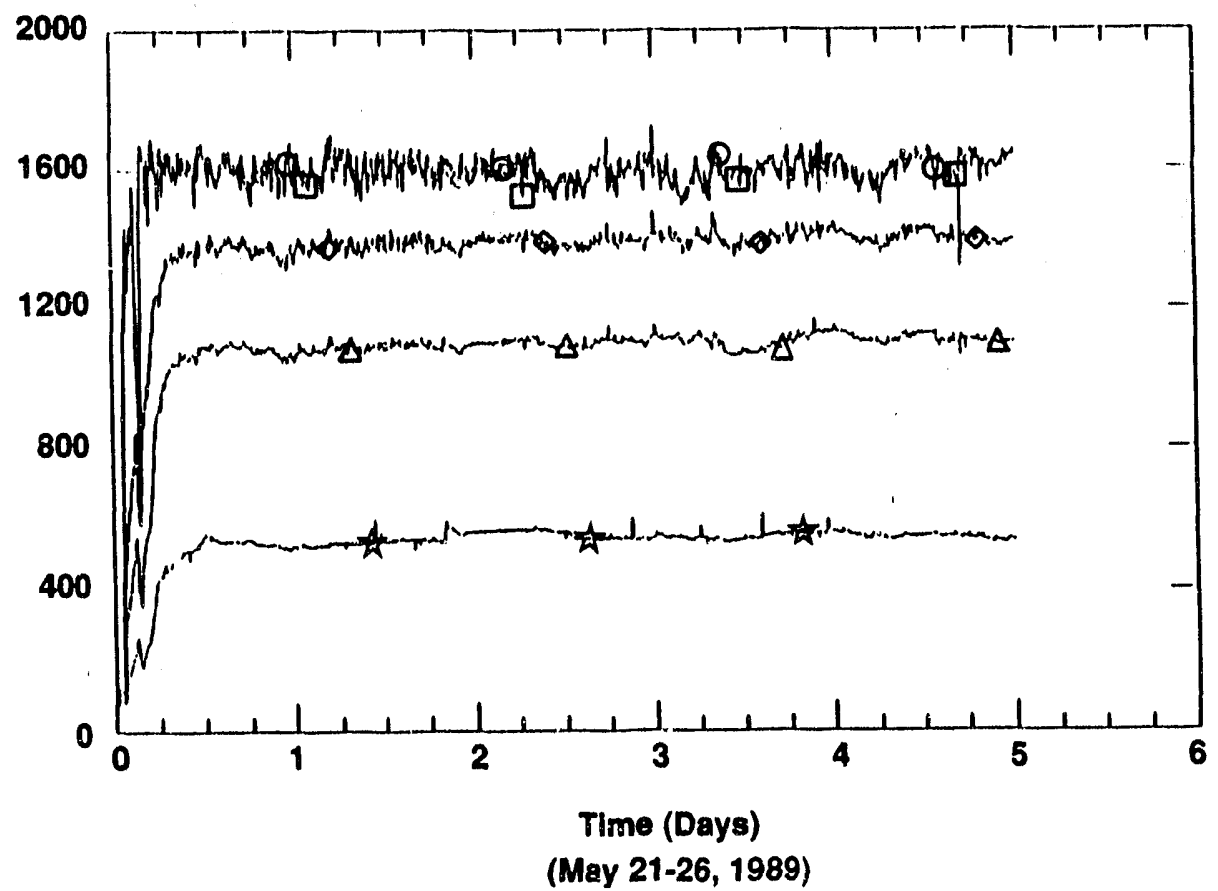

Distance above Distributor Plate

$0=3 \mathrm{ln}$.

$\square=12 \mathrm{ln}$.

$\diamond=36 \mathrm{in}$.

$\Delta=63$ in.

t $=96 \mathrm{in}$.

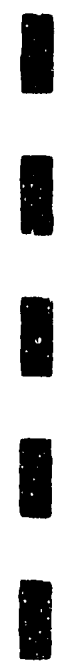

(May 21-26, 1989)

M91000895

rigure 12. Vertical Temperature Profile Through the 6-Inch ArBC 
The temperature at the freeboard sampling probe, which provided gas to the filter vessels, was typically $530^{\circ} \mathrm{F}$. Based on the freeboard gas temperature, combustor operating pressure, combustor flow rate, candle filter sampling rate, and the IDs of the freeboard and combustor sampling probe, deviations from isokinetic sampling conditions were determined. For the above conditions, the freeboard face velocity was $1.0 \mathrm{ft} / \mathrm{s}$ and the face velocity to the combustor sampling probe was $1.6 \mathrm{ft} / \mathrm{s}$. Consequently, sampling occurred at 608 above the desired isokinetic conditions for all. of the tests. While this seems high, the effects on the sample were believed to be small since the probe inlet was large and approximately half of the combustor process stream was extracted. The worst effect would have been to provide a sample that was not completely representative of the combustor. Such a skewed trend would have been an increase in the percentage of smaller particles per cubic foot of gas sampled. On the other hand, since the sampling conditions were generally the same for the three tests, there was no detrimental effect on the data analysis.

\subsection{Operational Characteristics of the Cyclone system}

Several deviations took place from the planned operation of the cyclone system. Originally, three cyclone configurations were planned: (1) a single primary cyclone (cyclone 1); (2) a primary and a secondary cyclone in series (cyclones 1 and 2): and (3) primary, secondary, and tertiary cyclone in series (cyclones 1, 2, and 3). The change in plans was motivated by the low anticipated particulate loading and the resultant time constraints if multiple cyclones in series were used. During the three tests, particulate size distributions were obtained by first using a single primary cyclone (cyclone 1); second, by using a straight unaltered combustor exhaust gas (no cyclone); and, finally, by using a secondary cyclone alone (cyclone 2). In application, the actual inlet velocities were $28 \mathrm{ft} / \mathrm{s}$ and $52 \mathrm{ft} / \mathrm{s}$ (based on inlet conditions of $1,210 \mathrm{scf} / \mathrm{h}$ at $25 \mathrm{psig}$ and $600^{\circ} \mathrm{F}$ ) for cyclones 1 and 2 , respectively. The average $d_{50}$ cuts, based on a coulter-counter volume-percent measurement for the two cyclones, were $13.03 \mu \mathrm{m}$ (cyclone 1), and $11.17 \mu \mathrm{m}$ (cyclone 2). The large deviationa from the theoretical $d_{50}$ cut size could be from the simplifying modifications made when the cyclones were built and the high operating temperatures. The respective cyclone outlet dusts concentrations were $1,826 \mathrm{ppmw}$ and 1,504 ppmw. The inlet dust loading was on the order of 7,500 ppmw. Appendix A includes the periodic weigh-backs from the respective cyclones.

Heaters on the cyclone system were designed to maintain the gas temperature. In practice, however, the gas stream was typically reheated. Inlet temperatures were typically about $550^{\circ} \mathrm{F}$; exit temperatures were about $800{ }^{\circ} \mathrm{F}$.

\subsection{Operational Characteristics of the Candle Filter Vessel}

Presented in Table 2 are the nominal operating conditions for the candle filter test series. Details of the candle-filter vessel performance and test 
series are in Appendix $B$, which includes process variable plots for all of the tests. Specific operational characteristics are presented below.

Table 2. Nominal Candle-Tilter Operating Range During the Test Series

Operating Parameter: Value
Inlet Temperature: 1,100 to $1,200^{\circ} \mathrm{F}$
Filter Face Temperature: 1,100 to $1,350^{\circ} \mathrm{F}$
Outlet Temperature: 1,100 to $1,350^{\circ} \mathrm{F}$
Pressure: $30 \mathrm{psig}$
Dust Loading: $1,504,1,826,7,725 \mathrm{ppmw}$
Time Cleaning: $1 \mathrm{~s}$ pulse every $1 \mathrm{~h}$
Cleaning Reservoir Pressure: 200 and $225 \mathrm{psig}$
Flow Rates: 1,200 to $1,300 \mathrm{scf} / \mathrm{h}$ (up to $2,000^{\mathrm{scf} / \mathrm{h} \text { ) }}$
Face Velocity: $13 \mathrm{ft} / \mathrm{min}$ (up to $20 \mathrm{ft} / \mathrm{min}$ )
Run Time: 30 to $60 \mathrm{~h}$ (up to. $100 \mathrm{~h}$ )

Candle filter gas temperatures were measured at three locations: one just at the inlet of the vessel, the second 0.5 inches from the candle filter surface mid-way along the longitudinal length, and finally as the gas left the candle filter just above the tubesheet. The inlet, mid-point, and exit temperatures, when averaged over time for all of the tests, were $1,280,1,321$, and $1,274{ }^{\circ} \mathrm{F}$, respectively. While the vertical variation in temperature seen here would not be characteristic of an actual filtering system, the difference between any of the temperatures was never greater then $80^{\circ} \mathrm{F}$ during any of the filtration tests (except during the preheat period at which time the middle candle filter temperature reached $1,725^{\circ} \mathrm{F}$ ). Not being able to operate the filter vessel at 1,500 to $1,600^{\circ} \mathrm{F}$ as planned was primarily because of the low gas temperature in the combustor freeboard.

An additional problem encountered in the operation was the pressure drop downstream of the filter vessel in the flow control loop. This problem did not affect the operation of the filter or the test results. However, a 958 open valve position was an undesirable control position. This situation prevented higher filter face velocities from being reached. Smaller particulate size distributions could also complicate the situation because of the inherent higher pressure drop of the resulting dust cake. This problem was caused by the high pressure drop through the gas-stream heat exchanger (cooling coil) and the in-line total filter (TF on Figure 2). Changing the orifice size of the valve trim would have corrected this problem, but was not implemented during the short test period.

The dust cake thickness detector performed extremely well on the bench top and equally well during the first few hours of operation. With the candle 
filter on line, the device was able to resolve dust cake build-up on the order of ten thousandths of an inch. Unfortunately, problems occurred in application: After a few cleaning cycles, the optical access ports became obscured with dust. This dust was predominately from the candle filter cleaning periods. The problem could be addressed with a shutter type arrangement attached to the access ports, which would only be opened for a short period of time just before and just after a cleaning cycle. A major limit to this laser-based system was the single point of resolution along the filter length. In this application, the dust cake was later found to be nonuniform along the lengt. $h_{1}$ of the filter.

The candle filter blow-back cleaning system worked well for the duration of the tests. With the reservoir pressure at 225 psig, a 1-second pulse typically delivered 3.4 scf of nitrogen to the filter.

\subsection{Operational Characteristics of the Disc Filter Vessel}

Three procedures were conducted in the disc filter test series:

(1) heated nitrogen was put through a clean disc filt $3 r$ to obtain baseline pressure drop measurements, (2) a particulate-laden gas was sampled isokinetically and sent to the disc filter for the formation of a dust cake, and (3) the established dust cake was subjected to clean heated nit.rogen at 10 different flow rates. Table 3 lists the nominal operating conditions for the disc filter vessel. Two problems that occurred during these procedures are discussed below.

Table 3. Nominal Disc-Filter Operating Range

\begin{tabular}{c} 
Operating Parameter: Value \\
\hline Filtration Temperature: 1,100 to $1,200^{\circ} \mathrm{F}$ \\
Pressure: Up to $30 \mathrm{psig}$ \\
Run Time: 0.5 to $14 \mathrm{~h}$ \\
Flow Rates of Dirty Gas or Clean Heated $\mathrm{N}_{2}: 0$ to $100 \mathrm{scf} / \mathrm{h}$ \\
Face Velocity: 0 to $20 \mathrm{ft} / \mathrm{min}$
\end{tabular}

During the disc filter dust-loading tests, the pressure drop suddenly decreased across the filter for some of the tests. Appendix $C$ shows this sudden decrease (e.g., DF8 and DF10). It was first thought that gasketing material had failed and formed a leak across the disc filter seal. However, upon inspection, signs of leaks were not obvious. In addition, the pressure drop after a sudden decrease never dropped below the pressure drop of the clean filter. If there were a leaking gasket, the leak was not enough to reduce the pressure drop to a value below that of a clean and intact filter 
gasket assembly. Furtinermore, this type of reducing pressure drop was not seen in any of the hot nitrogen flow tests. In an effort to further troubleshoot this situation, a different gasketing material (Grafoil, Durametallic Corporation) was tried, but the same phenomenon occasionally occurred. It is assumed that this decrease occurred as a result of a collapsing or cracking dust cake.

A major problem encountered with the disc filter vessel was the spalling and flaking of the ss shroud ( $304 \mathrm{ss}, 4-i n$. Schedule 5, pipe), which formed the flow passage from the dust inlet to the ceramic disc filter. When the vessel was cooled to facilitate removal of the disc filter, flakes of the shroud were found on the surface of the dust cake. Upon inspection, metal fragments were not found below the surface of the dust cake, which indicates that the flaking occurred only during the cool-down stage of the test. To solve this problem, the 4-in. ss pipe was replaced with a ceramic tube of appropriate length with a 3.5-in. OD and a 3.25-in. ID. All of the disc filter test results presented hers were conducted with the ceramic tube in place.

The isokinetic sampling system provided particulate-laden gas stream to the disc filter. Unfortunately, deviations from isokinetic conditions existed (Table 4). The deviations shown in Table 4 were determined, based on the difference in filtration conditions between the disc and candle filters. Positive deviations from isokinetic sampling conditions imply a higher probe inlet gas velocity, which would tend to increase the number of smaller particles in the gas stream. Under some conditions, deviations of this magnitude can exist from isokinetic conditions without a significant effect on the sampled gas stream (Tine 1961).

Table 4. Deriations rom Isokinetic Sampling for the Disc Filter Test Series

\begin{tabular}{cc}
\hline Disc Filter Test & $\begin{array}{c}\text { Above } \\
\text { Identification }\end{array}$ \\
Sampling Conditions \\
DF1 & $\star$ \\
DF2 & 9.8 \\
DF3 & 17.7 \\
DF4 & 7.9 \\
DF5 & 6.5 \\
DF6 & 12.8 \\
DF7 & 17.1 \\
DF8 & 10.4 \\
DF9 & 13.6 \\
DF10 & 18.6 \\
DF11 & 18.2 \\
Average & 13.2 \\
\hline
\end{tabular}

* Operational data lost during computer failure. 


\subsection{EXPERIMENTAL PROCZDURE}

Described here are the experimental procedures used for the three candle filter tests (CF1, CF2, and CF3) and the 11 disc filter tests (DF1 through DF11). The combustor was first preheated on natural gas until a bed temperature between 1,550 and $1,600{ }^{\circ} \mathrm{F}$ was reached. At that time, coal and limestone feeding was initiated. With the coal and limestone feed established, the combustcr pressure was increased by closing the valve on the back-pressure controller. As the pressure increased, the filow rate to the combustor was raised proportionally to maintain a superficial fluidizing velocity of approximately $5 \mathrm{ft} / \mathrm{s}$.

Combustor operating conditions for the tests were $2,500 \mathrm{scf} / \mathrm{h}$ of main fluidizing air, a bed temperature of $1,575^{\circ} \mathrm{F}$, and a pressure of $25 \mathrm{psig.}$ During this time, the candle filter and disc filter vessels were preheated to 1,700 to $1,750^{\circ} \mathrm{F}$. During the preheat period, $100 \mathrm{scf} / \mathrm{h}$ of heated nitrogen was sent through the cyclone system and was split at the isokinetic sampling probe, thus sending $80 \mathrm{scf} / \mathrm{h}$ to the candle filter vessel and $20 \mathrm{scf} / \mathrm{h}$ to the disc filter vessel.

Flowing preheated nitrogen reduced temperatures at localized hot spots produced by guard heaters on the sampling lines between the combustor and filter vessels. Once the combustor was operating at the desired test conditions, the $100 \mathrm{scf} / \mathrm{h}$ of heated nitrogen was used to pressurize the cycione system and candle filter vessel to $26 \mathrm{psig}$ ( 1 to 2 psi above the combustor pressure). This pressure permitted a smooth transition when the sampling line from the combustor to candle filter vessel was opened.

During the test period, three different particle size distributions were $g \in$ nerated and three candle filter tests were performed. The thiee size distributions were generated with the two different cyclone designs and the unaltered particulate-laden exhaust gas. The three candle filter tests (CF1; $C F 2$, and CF3) were distinguished by the size distribution generated. The combustor freeboard gas stream was typically sampled at a rate of $1,210 \mathrm{scf} / \mathrm{h}$. For this flow rate, temperature, and pressure, the candle filter face velocity was typically $13 \mathrm{ft} / \mathrm{min}$. Once simpling was initiated, the blow-back cleaning system was energized. For all of the tests, cleaning occurred every hour with a 1-second pulse of high pressure nitrogen. During a candle filter test, all pressure, pressure drop, flow rate, and temperature measurements were made and recorded on the Automatic Data Acquisition and Control System (ADACS). The ADACS system was set to record data every 3 seconds during all tests. ADACS was also used to analyze the recorded data.

Following a test, flow to the candle filter was shut off just after a cleaning pulse, and the vessel was allowed to cool to the ambient temperature. With the vessel at a workable temperature, the candle filter and dust catch pan were removed. At that time, separate weigh-backs werd made of the dust in the catch pan and the dust cake remaining on the candle filter (residual dust cake). Three samples were taken from the catch pan dust for coulter-counter size and chrmical analyses. Once the candle filter vessel and connecting flow 
lines were cleaned, modifications to the cyclone system were made to change the particulate size distribution reaching the filter vessels; then testing resumed.

When flow and temperatures in the candle filter vessel reached a steady state, isokinetic sampling for the disc filter test was started." With a disc filter installed prior to sending in the dirty process stream, heated nitrogen was passed through the filter in increments of 10 to $100 \mathrm{scf} / \mathrm{h}$. At each flow increment, a steady-state pressure drop was reached and recorded. This information was later used to characterize the clean disc filter before dust loading. Following the initial procedure with heated nitrogen, the appropriate valves were opened to isokinetically sample the dirty gas stream en route to the candle filter.

During all of the disc filter tests, an effort was made to maintain the same gas temperature measured at the disc filter as that measured at the midpoint of the candle filter. Keeping these temperatures as close as possible helped to ensure isokinetic sampling conditions between the diso and candle filters. Depending on the desired cake thickness and particulate loading, the disc filter vessel was operated from 0.5 to 14 hours. Following the loading of a filter, ADACS data plots were made as a function of time for the dust loading process. These plots indicated pressure drop, flow rate, and filtration temperature. With a set dust loading (cake thickness) on the filter, the particulate-laden gas stream was shut off, and the last phase of the disc filter test was initiated.

In the last phase of the test, hot clean nitrogen was introduced to the filter and dust cake in $10 \mathrm{scf} / \mathrm{h}$ intervals, in a fashion similar to the procedure conducted on the clean disc filter. Following the flow of nitrogen in $10 \mathrm{scf} / \mathrm{h}$ increments, the filter assembly was cooled to approximately $600^{\circ} \mathrm{F}$ and was removed from the vessel. The filter hold-down flange was then removed and the hot filter was placed in a Petri dish and stored in a large desiccator. The desiccator was stored in an oven at $400^{\circ} \mathrm{F}$ for 12 hours and then was allowed to cool to room temperature. Once the filter and dust cake (stil.1 in the desiccator) cooled to room temperature, the dust cake thickness and mass were measured. Measurement of the dust cake thickness was made with a vernier calliper to the nearest 0.010 inch. The cake mass was then determined to within 0.1 grams. During the three candle filter tests, 11 disc filter tests. were conducted. 


\subsection{TEST RESULTS}

\subsection{Candle rilter Test Results}

Standard methods for analyzing the candle filter test results were employed. The main objective was to evaluate the specific flow resistance $\left(K_{2}\right)$ of the dust cake for the three different tests. In the three candle filter tests (CF1, CF2, and CF3), the main objective was to evaluate the effect of particle size on $K_{2}$. Consequently, particle size was the only parameter varied.

Figure 13 illustrates a typical pressure drop versus time signature for barrier-filter dust-cake filtration with periodic blow-back cleaning. The cleaning cycle is triggered by either a preset time interval or a maximum pressure. $P_{0}$ represents the pressure drop associated with various system components present in the flow stream between the high and low side of the pressure measurement ports. Essentially, $P_{0}$ is the filter vessel's pressure drop without a candle filter in place. Depending on the location of pressure tap ports, the components of a filter vessel can include the dirty gas eritrance nozzle, filter tubesheet, filter hold-down flange, and the clean gas exit nozzle. $P_{1}$ represents the same pressure drop as $P_{0}$ but with a clean virgin candle filter in place that is subjected to a dirty gas stream at time zero. The saw tooth appearance of the pressure drop line represents the increasing pressure drop with time as the dirty gas stream is filtered, a dust cake is formed, and the filter is periodically cleaned. Time $T_{1}$ is the time required

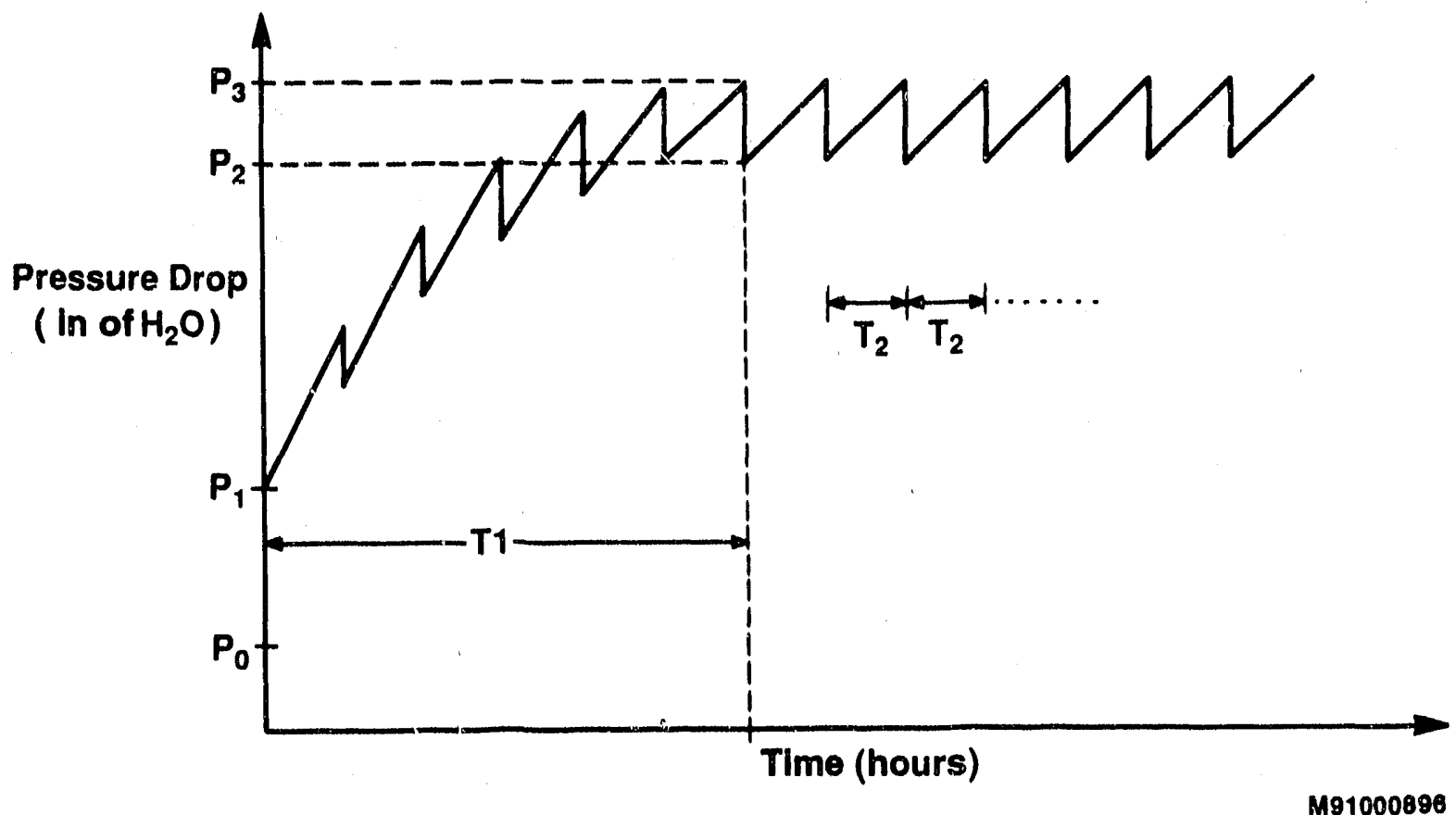

Figure 13. Characteristic Rressure Drop Vexsus Time for a Barrier Filter 
for the formation of a steady-state residual dust cake on the filter. A residual dust cake is particulate that remains on the filter and is typically not removed during a cleaning oyjle. $P_{2}$ is the low pressure drop just after the filter is cleaned, and $P_{3}$ is the pressure drop of the dirty filter just before cleaning.

Filter cleaning can be time initiated, in which case the filtration time interval $\mathrm{T}_{2}$ will be set. If the dust concentration and filtration conditions remain constant, the rate of change in pressure drop between $P_{2}$ and $P_{3}$ will remain constant. Alternatively, if cleaning is triggered by a high pressure occurring when $P_{3}$ is reached, and if the filtration conditions and dust concentration remain constant, the filtration interval $\mathrm{T}_{2}$ will be equal for all cycles.

Leith and Allen (1986) defined dust cake specific flow resistance, $K_{2}$, to be the pressure drop through the dust cake, $\mathrm{P}_{\mathrm{d}^{\prime}}$ divided by the quantity face velocity, $v_{f^{\prime}}$ times the areal density, $w_{0}$ :

$$
K_{2}=P_{d} /\left[\left(V_{f}\right)\left(W_{d}\right)\right] .
$$

In this relationship, the areal density is the average dust cake mass per unit area. In Figure 13, $P_{d}$ is the difference between $P_{3}$ and $P_{2}$. The value in Equation 1 that is difficult to determine, since the cleaning cycle periodically removes the accumulated dust, is the dust cake areal density. To determine the amount of dust added to the unit filter area per filtration cycle, the dust concentration must be determined and the filtration face velocity known. With these two quantities, the areal dust density can be written in terms of the filtration face velocity, dust loading, $C_{D^{\prime}}$ and filtration time, $\mathrm{T}_{2}$ :

$$
W_{0}=\left(C_{D}\right) \quad\left(V_{2}\right)\left(T_{2}\right)
$$

By substituting Equation 2 into Equation 1, an expression for the specific flow resistance $k_{2}$ is developed, based on experimentally determined quantities:

$$
K_{2}=P_{d} /\left[\left(V_{P}{ }^{2}\right)\left(C_{D}\right)\left(T_{2}\right)\right] .
$$

In the candle filter tests, the dust concentration, $C_{D}$, was determined by dividing the collected mass of dust by the total amount of gas passing through the filter. The total dust collected was determined by weighing the dust from the candle filter's catch-pan and the residual dust cake, which was still on the filter at the end of a test. A total gas volume sent through the filter for the period of the test was determined by multiplying the average candle filter flow rate by the length of the test period. This flow rate information was taken from the ADACS data, in a manner similar to the plots presented in Appendix B. The actual data used in calculating $K_{2}$ was taken from ADACS plots that were manipulated to remove the initial and final low points. (These low points were not part of the actual test time and would have tended to lower the actual statistics used in calculating the total flow.) 
Figure 13 can also be used to lillustrate how the mass of the residual dust cake can be calculated. The residual dust cake is dust that remains on the filter after repeated cleaning cycles. The residual dust cake typically forms in a finite period of time, $T_{1}$. The amount of dust involved in the residual dust cake can be estimated by first assuming that the specific flow resistance, $K_{2}$, calculated for the steady state cleaning cycles is the same for the residual cake. Then Equation 1 can be solved for the areal density of the dust cake, which is assumed to be equal to the mass of the residual dust cake divided by the filter area. The pressure drop used jin this equation is now the difference between $P_{2}$ and $P_{1}$ :

$$
W_{R}=\left(P_{2}-P_{1}\right) /\left[\left(V_{f}\right)\left(K_{2}\right)\right] \text {. }
$$

Appendix B presents the filter vessel's flow rates, filter face velocities, pressure drop signatures, and filter temperatures as a function of time for the three tests $C F 1, C F 2$, and $C F 3$. Table 5 summarizes the results of the three candle filter tests.

Canale Filter Test One (CF1) was conducted for approximately $34 \mathrm{~h}$ with a single primary cyclone in-line. During the test, the filter vessel pressure averaged 23.7 psigy with a standard deviation of $1.6 \mathrm{psi}$. The pressure in the blow-back cleaning reservoir averaged $207 \mathrm{psig.} \mathrm{Filter} \mathrm{inlet,} \mathrm{mid-point,} \mathrm{and}$ out let temperature profiles are shown in Appendix B. The temperature plots show that the filter vessel cavity was preheated to a temperature of $1,705^{\circ} \mathrm{F}$ prior to introduction of the particulate-laden gas stream. When the dirty gas was introduced, the mid-point candle filter temperature cooled down to the incoming gas temperature. The apparent drop in the candle filter outlet temperature just before hour 30 of the test was caused by a momentary thermal couple failure.

Flow rate through the candle filter averaged $1,210.8 \mathrm{scf} / \mathrm{h}$. Based on the flow rate, the vessel pressure, and the candle filter mid-point temperature, an average face velocity of $13.1 \mathrm{ft} / \mathrm{min}$ was calculated. The total gas passing the filter was measured to be $41,639.8 \mathrm{scf}$; the resulting dust collected was $5.7 \mathrm{lb}$. The residual dust cake was measured to have a mass of $0.21 \mathrm{lb}$. The pressure drop versus time signature for this test showed the characteristic increase in pressure drop for the freshly cleaned filter until the developing residual dust cake reached a steady state. Approximately 24 hours were required to form a steady-state residual dust cake.

Starting at hour 25, the subsequent nine cleaning cycles were used to determine an average $k_{2}$ value. The last filtration cycle was not used since it was cut short of a full hour. The average $K_{2}$ value was calculated, using Equation 3 , to be 33.0 in $\mathrm{H}_{2} \mathrm{O} \mathrm{ft} \mathrm{min} / \mathrm{lb}$, with a standard deviation of $9.5 \mathrm{in} \mathrm{H}_{2} \mathrm{O} \mathrm{ft} \mathrm{min} / \mathrm{lb}$. The average particle diameter, based on the volume of collected dust, was $6.8 \mu \mathrm{m}$ with an overall particulate concentration of 1,826 ppmw. The mass of the residual dust cake was determined, using Equation 4 , to be $0.16 \mathrm{lb}$.

Candle Filter Test Two (CF2) was conducted without a cyclone in-line, allowing the unaltered AFBC particulate-laden gas stream to reach the candle 
Table 5. Sumary of Results From Candla-filter Test Series

\begin{tabular}{|c|c|c|c|}
\hline Test Parameter & CE'1 & CF2 & CF3 \\
\hline Date & $5 / 19-20 / 89$ & $5 / 21-23 / 89$ & $5 / 23-26 / 89$ \\
\hline Run Time (h) & 34 & 35.5 & 64 \\
\hline Cyclone Configuration & Cyclone 1 & No Cyclone & Cyclone 2 \\
\hline Face Velocity (ft/min) & 13.1 & 13.1 & 13.2 \\
\hline Particle Density $\left(\mathrm{g} / \mathrm{cm}^{3}\right)$ & 2.79 & 2.79 & 2.80 \\
\hline $\begin{array}{l}\text { Average Particle Diameter by } \\
\text { Volume }(\mu \mathrm{m})\end{array}$ & 6.83 & 11.4 & 8.27 \\
\hline $\begin{array}{l}\text { Average Particle Diameter by } \\
\text { Population }(\mu \mathrm{m})\end{array}$ & 2.75 & 4.01 & 2.95 \\
\hline Average Surface Area $\left(B \mathrm{ET}^{*} \mathrm{~m}^{2} / \mathrm{g}\right)$ & $5 / 38$ & 11.0 & 7.5 \\
\hline Dust Concentration (ppmw) & 1,826 & 7,725 & 1,504 \\
\hline Average Temperature $\left({ }^{\circ} \mathrm{F}\right)$ & 1,318 & 1,309 & 1,331 \\
\hline Average Vessel Pressure (psig) & 23.7 & 23.8 & 23.5 \\
\hline $\mathrm{K}_{2}\left(\mathrm{in} \mathrm{H}_{2} \mathrm{O}\right.$ ft $\left.\mathrm{min} / \mathrm{lb}\right)$ & 33.0 & 7.4 & 40.7 \\
\hline $\begin{array}{l}\text { Residual Dust Cake Mass Calculated } \\
\text { (1b) }\end{array}$ & 0.16 & 0.78 & 0.24 \\
\hline $\begin{array}{l}\text { Total Pressure Drop Before Cleaning } \\
\text { (psig) }\end{array}$ & 4.4 & 4.0 & 5.0 \\
\hline
\end{tabular}

* Brunauer, Emmitt, Teller

filter. This test was broken into two time periods because the candle filter vessel was taken off-line after a plug in the downstream flow control loop. Since the filter was down for a short period and the test at that time had only lasted 4.5 hours, the candle filter vessel was not cleaned out; the dust collected was averaged into the second part of the test.

The second part of CF2 lasted 31 hours with an average vessel pressure of $23.8 \mathrm{psig}$ and a standard deviation of $1.8 \mathrm{psi}$. The second part of CF2 had an average flow rate of $1,222.6 \mathrm{scf} / \mathrm{h}$ with a standard deviation of $126.8 \mathrm{scf} / \mathrm{h}$. Temperature, pressure, and flow rate conditions produced a candle filter face velocity of $13.1 \mathrm{ft} / \mathrm{min}$ with a standard deviation of $1.0 \mathrm{ft} / \mathrm{min}$. 
The total dust collected and the gas passing filter were measured for the combined parts of CF2 and found to be $25.6 \mathrm{lb}$ and $44,1.78 .5$ scf, respectively. Unfortunately, the residual dust cake mass in this test was not kept. separate from the pan dust. At hour 22 of the second part of this test, the blow-back cleaning reservolr pressure was increased from 200 psig to $225 \mathrm{psig}$. Increasing the cleaning pressure effectively removed the residual dust cake, which had reached a steady state 17 hours into the test (when the blow-back reservoir was set at 200 psig).

Subsequent to the formation of the second residual dust cake, five filtration cycles were used to calculate $K_{2}$. The average $K_{2}$ value was determined to be 7.4 in $\mathrm{H}_{2} \mathrm{O}$ ft $\mathrm{min} / 1 \mathrm{~b}$ with a standard deviation of 0.9 in $\mathrm{H}_{2} \mathrm{O} \mathrm{ft} \mathrm{min} / \mathrm{lb}$. The average particle diameter based on volume was $11.4 \mu \mathrm{m}$ for the collected dust, with an overall particulate concentration of $7,725 \mathrm{ppmw}$. The residual dust cake mass was calculated to be $0.78 \mathrm{lb} / \mathrm{ft}^{2}$.

Candle Filter Test Three (CF3) was conducted for 64 hours (an ADACS failure 60 hours into the test prevented the last 4 hours of data from being recorded). The filter vessel pressure averaged $23.5 \mathrm{psig}$ with a standard deviation of $1.3 \mathrm{psi}$. An average pressure of $227 \mathrm{psig}$ was maintained in the blow-back reservoir during the entire test period. Dirty gas was filtered at a rate of $1,205 \mathrm{sof} / \mathrm{h}$ with a standard deviation of $94.5 \mathrm{scf} / \mathrm{h}$. Using these conditions, a filter face velocity of $13.2 \mathrm{ft} / \mathrm{min}$ was calculated with a standard deviation $0.8 \mathrm{ft} / \mathrm{min}$. During the 64 -hour test, $77,548.8$ scf of gas passed through the filter, depositing $8.75 \mathrm{lb}$ of dust. The residual dust cake weighed $1.15 \mathrm{lb}$.

The stable residual dust cake was removed from the filter at hour 41 . When this occurred, the candle filter pressure drop returned to its initial clean value. At this time there was no incident that could be associated with the detachment of the initial residual dust cake. Following the upset, a new residual dust cake formed, taking approximately 24 hours to reach a steady state.

The subsequent 18 filtration cycles were used to calculate an average $K_{2}$ value of 40.7 in $\mathrm{H}_{2} \mathrm{O} \mathrm{ft} \mathrm{min} / \mathrm{lb}$ with a standard deviation of 4.3 in $\mathrm{H}_{3} \mathrm{O} \mathrm{ft} \mathrm{min} / \mathrm{lb}$. The average particle diameter based on volume was $8.2 \mu \mathrm{m}$ for the collected dust, at a total dust concentration of $1,504 \mathrm{ppmw}$. The calculated residual dust cake mass was determined to be $0.20 \mathrm{lb}$ for the first period and $0.24 \mathrm{lb}$ for the second period.

The average particle size was measured for each test using coulter counter analysis of three grab samples taken from the dust catch pan following the test. Table 6 summarizes those samples averaged to determine a mean particle size. Appendix F contains chemical and morphological data on the three dust samples. Scanning electron micrographs presented in Appendix $\mathbf{E}$ show the random pore structure of the "cracker like" dust cakes found on the filter and in the catch pan. Appendix $\mathrm{E}$ also includes laboratory measurements of the catch pan dust properties that can be used to compare these samples to other

${ }^{3}$ D. Pontius, Southern Research Institute. June 23, 1989. Personal Communication with C. Zeh, METC. 
Table 6. Sumaxy of Raxticulate Grab Samples Irom Candle-filter Test Series

\begin{tabular}{ccccc}
\hline $\begin{array}{c}\text { Sample } \\
\text { Identification }\end{array}$ & $\begin{array}{c}\text { Particle } \\
\text { Diameter } \\
\text { by Volume } \\
(\mu \mathrm{m})\end{array}$ & $\begin{array}{c}\text { Particle } \\
\text { Diameter } \\
\text { bopulation } \\
(\mu \mathrm{m})\end{array}$ & $\begin{array}{c}\text { Particle } \\
\text { Density } \\
\left(\mathrm{g} / \mathrm{cm}^{3}\right)\end{array}$ & $\begin{array}{c}\text { BET Surface } \\
\text { Area }\left(\mathrm{M}^{2} / \mathrm{g}\right)\end{array}$ \\
\hline CF1 & & & & \\
R11-1 & 6.66 & 2.57 & 2.78 & 6.43 \\
R11-2 & 8.51 & 3.02 & 2.80 & 8.15 \\
R11-3 & 5.32 & 2.66 & 2.80 & 1.57 \\
Average & 6.83 & 2.75 & 2.79 & 5.38 \\
CF2 & 15.06 & 4.92 & 2.84 & 27.66 \\
R12-1 & 10.60 & 3.98 & 2.75 & 3.79 \\
R12-2 & 8.64 & 3.65 & 2.80 & 1.55 \\
R12-3 & 11.40 & 4.01 & 2.79 & 11.00 \\
Average & & & & 2.89 \\
CF3 & 8.27 & 2.95 & 2.80 & 7.50 \\
\hline R13-1 & 9.80 & 3.45 & 2.86 & 17.91 \\
R13-2 & 8.21 & 3.23 & 2.68 & 3.22 \\
R13-3 & 6.80 & 2.17 & 2.87 & 1.55 \\
Average & & & & \\
\hline
\end{tabular}

combustor dust effluents (Vann Bush, Snyder, and Chang 1987; Vann Bush, Snyder, and Smith 1989; Pruce 1981). Laboratory properties of the AFBC dust appeared to be similar to that of other combustors, except for the high carbon content of some samples.

\subsection{Disc Filter Test Results}

The main objective of the disc filter test series was to generate fundamental dust cake filtration data in a small-scale test facility. Test results were used to evaluate the effects of particle size on $K_{2}$, to compare smallscale disc filtration data with full-size candle filter data, and to examine additional aspects of dust cake filtration phenomena. 
For each of the 11 disc filter tests (DF1 through DF11), three separate procedures were conducted. These procedures included passing hot clean nitrogen in increments of 10 to $100 \mathrm{scf} / \mathrm{h}$ through a clean disc filter to record a baseline pressure drop. Then the dirty gas stream was sampled for the formation of a dust cake on the disc filter. Finally, the dirty gas stream was shut off and hot clean nitrogen was passed through the disc filter in increments of 10 to $100 \mathrm{scf} / \mathrm{h}$ with a dust cake formed on the filter.

Results of the dust loading portion of the disc filter test series are summarized in Table 7. Appendix $C$ presents ADACS data plots of the actual dust loading period; Appendix $C$ also includes plots of the filter face velocity, filter exit temperature, vessel pressure, flow rate, and pressure drop. The plots of the dust loading period were used to calculate a $K_{2}$ value based on the maximum pressure drop reached during the loading period, the measured face velocity, and the areal density of the weighed-back dust. Appendix $D$ contains the tabulated data from passing clean heated nitrogen through the formed dust cake and the chemical and physical analysis of the resulting dust cake. Appendiy $n$ also includes graphs of hot clean nitrogen being passed through the formed dust cake in increments of $10 \mathrm{scf} / \mathrm{h}$ as plots of face velocity versus pressure drop and specific flow resistance $\left(K_{2}\right)$ versus face velocity.

\subsection{Discussion of Results}

The most significant result from this test series is the quantification of the effect of particle size on specific flow resistance $\left(K_{2}\right)$ for various dust cakes. This effect is exhibited in both candle filter and disc filter dust cakes when results are compared within each test block. In the candle filter test block, when the effect of particle size on $k_{2}$ is compared between tests CF1 and CF2, a 40 reduction in mean particle diameter by volume produced a 3468 increase in $K_{2}$. Likewise, when CF2 is compared to CF3, a 268 reduction in particle size produced an increase in $K_{2}$ of 4508 . While the exact $\mathrm{K}_{2}$ values cannot be compared between the disc and candle filter tests, a similar trend is seen in the disc filtration data. Caution must be used when comparing the disc filter data directly with the candle filter data, since particle size, dust cake thickness, and face velocity may be different.

There is some variability in the candle filter test data, and this is evident for the measurements of both particle size and $k_{2}$. The variability in $\mathrm{K}_{2}$, quantifict with standard deviations, is produced by the variation in pressure drop during each cleaning cycle for the period in which $\mathrm{K}_{2}$ is calculated. The fluctuation in pressure drop could be caused by variations in dust concentrations exiting the fluidized-bed combustor, carried over through the cyclone system, and delivered to the candle filter. Higher dust loadings will produce higher pressure drops within equal filtration periods.

An alternate theory for this variation is that the residual dust cake changes after a quasi-steady state has been reached. This theory is supported by the somewhat similar slopes of the pressure drop versus time cycles while 


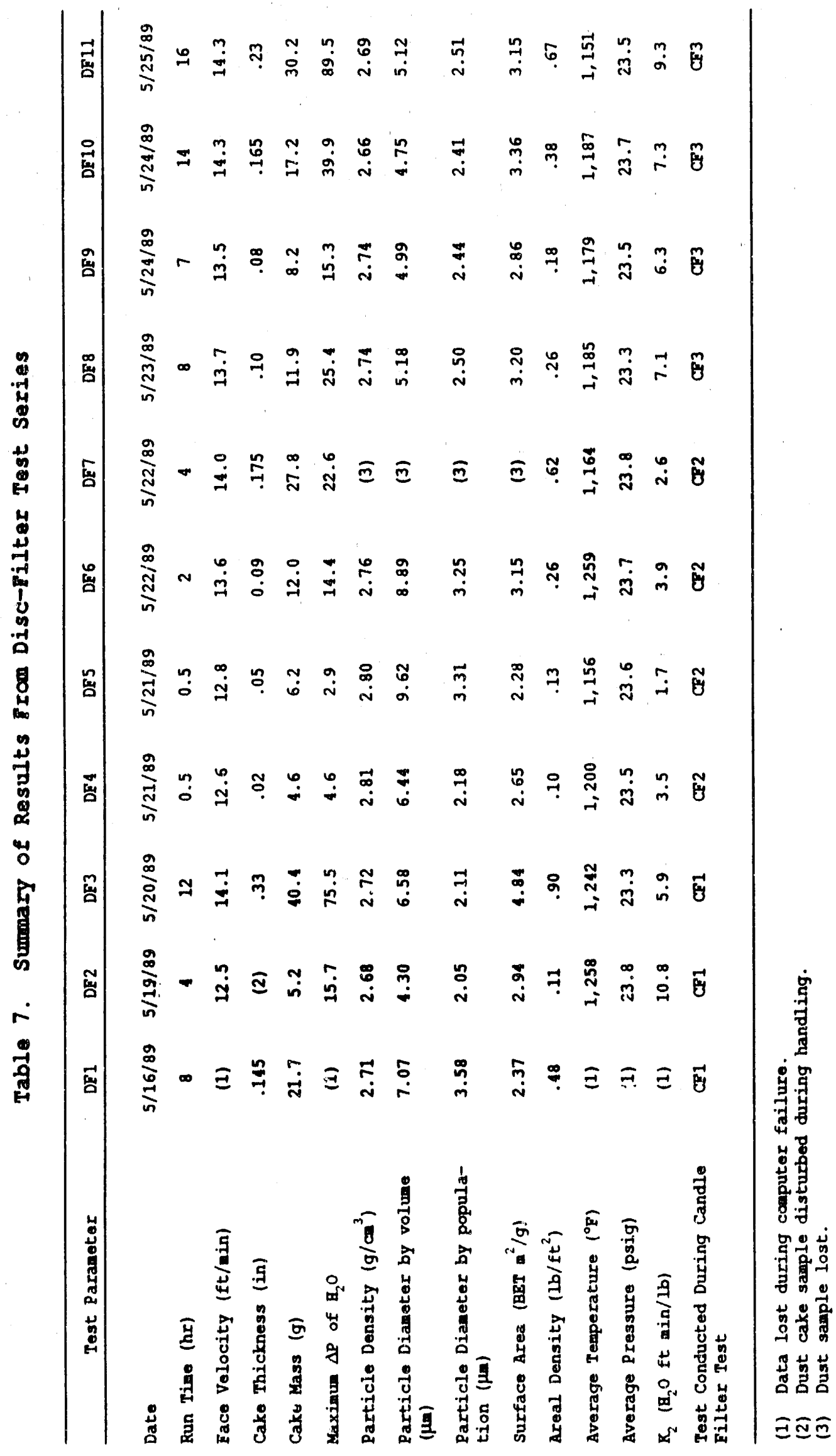


the residual dust cake is forming (indicating uniform dust loading). Once the residual dust cake appears to have reached a steady state, it then begins to outgrow its own supporting mechanisms and decay. This reforming and decaying procedure could produce filter-flow pressure-drop characteristics that would produce different pressure drop versus time slopes. The variation (as measured with standard deviation) in pressure drop for the three candle filter tests was similar to the variation in $K_{2}$ for a particular test. The exact variation in pressure drop can be quantified from the ADACS plots of pressure drop versus time for each test.

An additional source of error that affects the strength and confidence of this particle size versus $K_{2}$ trend is associated with the particle size measurement. While the size distributions from cyclone 1 (CF1) and cyclone 2 (CF3) were expected to be close, it was assumed that, based on the cyclone design, the particulate size distribution leaving cyclone 2 would be smaller than that leaving cyclone 1 . However, the coulter counter measurements in Table 5 indicate that this was not the case. This could be because the three grab samples taken from the candle filter's catch pan for either CF 1 or CF 3 did not represent the actual mean particle size distribution. Also, high temperature effects on gas viscosity have been known to foul cyclone performance, altering the predicted $d_{50}$ size. All other indicators, such as the calculation of $K_{2}$, the dust concentration, and the designed $d_{50}$ cut size of cyclone 2 , indicate that a smaller particle size should have been delivered and measured from cyclone 2 .

Theory can be used to examine the particle size versus $k_{2}$ trend. If a simple expression is used for the areal density of the dust cake (Leith and Allen 1986), and if Equation 5 is substituted into Equation 1, the resulting Equation 6 can be solved for $k_{2}$. Equation 6 shows that $k_{2}$ will. vary by the inverse cubed power of the particle diameter. The magnitude of the trend produced from the experimental data is similar.

$$
\begin{gathered}
W_{c}=\left[(N)(R O)(\pi)\left(D^{3}\right)\right] / 6 \text {, and } \\
K_{2}=\left(\begin{array}{llllll}
6 & \left.P_{d}\right) /\left[\left(V_{f}\right)\right. & (R O) & (\pi) & \left(D^{3}\right) & (N)
\end{array}\right] .
\end{gathered}
$$

In calculating the residual dust cake, two assumptions were made:

(1) the $K_{2}$ value calculated during the filtration cycles was assumed to be applicable to the residual dust cake, and (2) the residual dust cake was assumed to be uniform over the length of the candle filter. The distribution of the dust cake was clearly not uniform over the length of the candle filter. Typically, a bulbous dust cake was found at the end of the filter and a short cylindrical segment was found midway along the length of the filter. Between these two irregular sections and above the cylindrical section, there was typically a thin (approximately 0.125 to 0.25 in. thick) "cracker"-like cake (i.e., cracker-like in the sense that pieces of the dust cake could be hand held and snapped like a cracker).

The irregularity in the distribution of the residual dust cake was most likely caused by the vessel and filter configuration used in these tests. Specifically, the location of the dust inlet nozzle contributed to the bulbous 
region developed on the end of the filter. The cylindrical section that developed along the middle section of the candle filter was probably related to the settling time for the collected dust as it was blown off the filter during a cleaning pulse. During the short 1-second cleaning pulse, the flow of filtrate was momentarily reversed as the dust cake was removed from the filter; then the normal flow of filtrate resumed. However, during this short 1-second period of time, the removed dust either fell into the vessel catch pan or was re-entrained into the incoming dirty gas. If this was indeed the case, and if the dust did not settle past the mid-point of the filter, then when the incoming gas stream resumed, the dust concentration at the filter mid-point was high. This causes a thicker dust cake and presumably a thicker residual dust cake to form. This same phenomenon could have contributed to the bulbous development on the end of the candle filter.

Another possible source of the cylindrical section of residual dust cake could have been from the nonheated section of the candle filter shroud directly across from the vessel viewing ports. The phenomenon would presumably be related to a local cool spot. The cylindrical section was typically 4 inches long (similar to the nonheated section needed for the viewing ports) and 2 inches higher then the elevation of the viewing ports.

During the dust loading period in the disc filter tests, it was difficult to ascertain the impact of cake thickness (areal density) on the value of $k_{2}$, except that they were directly related and that the areal density effect was probably an order of magnitude weaker then the effect of average particle diameter. Disc filter tests DF8 through DF11 illustrate this. In these tests dust was collected with the same cyclone configuration and had the smallest variation in average particle size. (The largest variation was 5.18.) Assuming that the particle sizes were equal for this analysis, cake thickness had a weak but directly related effect on $K_{2}$. For instance, if DF8 is compared to DF10, a doubling of the cake thickness produced a 318 increase in the $K_{2}$ value. This effect was at least an order of magnitude weaker than the effect of particle size. The ratio of dust cake thickness to cake mass was not consistent for all disc filter tests, suggesting that compression and consolidation could have been occurring for the cakes with higher mass (higher areal density and cake thickness). That is, cakes of higher mass per unit area produced a higher pressure drop, resulting in additional consolidation and reduced cake thickness. Again, the overall effect on $K_{2}$ is not strong.

After the dust loading period, the formed dust cake was subjected to 10 different face velocities by increasing the flow of clean heated nitrogen through the cake from 0 to $100 \mathrm{scf} / \mathrm{h}$ in $10 \mathrm{scf} / \mathrm{h}$ increments. The objective of this test was to evaluate phenomenological behavior of dust cakes (preformed in this case) subjected to different face velocities. These data, graphically summarized in Appendix $D$, illustrate the effects of face velocity on $\mathrm{K}_{2}$. While it was difficult to explain the large and sudden increases in $\mathrm{K}_{2}$ in some of the tests, all tests showed an increase. The larger increases in $\mathrm{K}_{2}$ tended to occur for the thinner cakes. This was probably caused by the more continuous nature of thin cakes, which allowed an increase in momentum (because of the increase in face velocity) to be transmitted; this compacted the entire cake. Conversely, a thick cake distributed the momentum force 
through the cake structure, thereby sheltering the lower portions of the cake from consolidation forces. Similar trends seem to have been produced by other researchers (Rothwell 1976, 1985, 1986; Holland and Rothwell 1977a, 1977b). The dust cakes subjected to clean heated nitrogen in this portion of the test series were formed at face velocities ranging between 12.5 and $14.3 \mathrm{ft} / \mathrm{min}$, and had an internal structure corresponding to the formation face velocity.

Using the range of face velocities produced by the heated nitrogen with an assumed average particle size of $7.0 \mu \mathrm{m}$ and other properties calculated at 40 psia and $1,300{ }^{\circ} \mathrm{F}$, the Reynolds number was found to vary from 0.0016 to 0.010 (flow dominated by viscous drag) for tests DF1 through DF11. It was then assumed for the disc filter tests that a change in the Reynolds number by an order of magnitude caused by an increase in the momentum forces would produce a small increase in $K_{2}(5$ to $20 \%)$ for thick dust cakes and a moderate to large (50 to 4008) increase for thin dust cakes.

This analysis was semi-qualitative and the dust cakes were formed at fixed velocities. However, this reasoning can be extended to a HTHP filtration application. In such a case, the Reynolds number will still be low, or about 0.20 (assuming there is no effect of pressure on the viscosity), and will still be governed by viscous forces. Consequently, when the momentum forces are increased by an order of magnitude in a HTHP application, the $K_{2}$ value will rise by 5 to $20 \%$ for thick dust cakes and even higher for thin dust cakes.

In other words, if candle filter test CF2 (the candle filter test that had a thick dust cake per filtration cycle) were conducted at a pressure of 165 psig, then the consolidation effects on the candle filter would have been similar to a disc filter. Furthermore, if the particulate size and morphology of the effluent from a PFBC were the same as that from this AFBC, then the resulting $K_{2}$ might increase from 7.4 to 8.8 in $\mathrm{H}_{2} \mathrm{O}$ ft $\mathrm{min} / \mathrm{lb}$.

Caution should be used in extending the disc filter results to a fullsize candle filter test at high or low pressure since these tosts were done with pre-formed dust cakes at a set face velocity. In addition, the consolidation phenomenon would be different for a dust cake that was continuously being formed. This would be opposite of that for the disc filter cakes, which were formed at a fixed face velocity to a set thickness and then were exposed to increasing face velocity without the addition of more dust.

Two types of pressure effects can be discussed in relation to hightemperature dust cake filtration: (1) effects of pressure on the filtration fluid mechanics, and (2) effects of pressure on dust cake consolidation properties. An increase in the gas pressure will proportionally increase the gas density, momentum, and consequently, the mass flux of filtrate through the filter. Furthermore, the effect of an increase in pressure on the gas viscosity will be less than $5 \%$ at ambient temperature and probably less than 18 at elevated temperatures (Miller 1983). It has been shown that for operating conditions of about 177 psia and $1,550^{\circ} \mathrm{F}$ and for porosities expected from PFBC-derived dust cakes, the filtrate Reynolds number will be less then 1.0 (Seville et al. 1989) and will probably be 0.1 to 0.3 . This range in Reynolds 
number yields a laminar flow regime, governed by viscous forces (Collins 1961; Hillel 1980). Consequently, for a fixed face velocity and operating temperature and an incompressible dust cake, an increase in absolute pressure by an order of magnitude will not increase the pressure drop through the filter. A similar type of pressure effect on pressure drop has been empirically shown for flow through fixed packed beds with the Ergun equation (Kunii and Levenspiel 1969).

The pressure increase and resulting increase in gas momentum will have an effect on the structure, formation, and resulting $K_{2}$ values of the dust cake. The dust cake structure will show a change in porosity, which is characterized by the value of $K_{2}$. This increase in momentum will be similar to the effect seen when the clean heated nitrogen was passed through the pre-formed dust cake in the disc-filter test series. In the test series, the flow Reynolds number and resulting momentum were increased by an order of magnitude, producing a smail increase in $K_{2}$ for thick cakes and a large increase for thin cakes. It is difficult to predict how strong this effect will be in largescale pressurized filter applications with continuously forming dust cakes. However, we hypothesize that the increase in $K_{2}$ will be about 10 to 208 if thick cakes are established.

Another phenomenon that may be affected by the pressure increase is the supporting function of the fluid as it passes through the cake structure. This fluid will have a higher density because of an increase in pressure. Thus, it may support the dust cake better than a less dense fluid. However, it is difficult to predict how strong this effect will be. This effect may counteract dust cake consolidation tendencies caused by an increase in pressure.

The difference in $K_{2}$ values between the disc and candle filter is to be expected. The difference can be caused by many factors, including particle size distribution, particulate morphology, cake thickness, face velocity, filtrate properties, and filter configuration. The isokinetic sampling in the disc filter tests was designed to maintain equal particulate size distributions on both filters; however, there were substantial variations. These variations and the difference in $K_{2}$ values reaffirm the care that must be taken when trying to characterize the particulate from small-scale test facilities and to then extend these characteristics to a full-scale application. Care should also be taken when $k_{2}$ values for one or two candle filter systems are extended to larger commercial-scale systems. In general, the $K_{2}$ value measured in a small-scale system will not be directly indicative of full-scale values. Helfritch (1972) presented a similar result. This caution will be true even if the particulate size distributions are equal, since other factors such as filter geometry affect the consolidation tendencies and the resulting $K_{2}$ value. However, key parameters (particulate size distribution in this case) showed the same trend and similar magnitudes in both the full-size candle-filter test block and in the small-scale disc-filter test block.

The candle filter and cleaning system operated well for these test conditions. This was typified by the moderate pressure drop through the filtering 
system of 4 to 5 psi. This pressure drop was associated with a face velocity of $13 \mathrm{ft} / \mathrm{min}$ and two different dust loadings on the order of 7,700 to 1,500 ppmw. Caution must be used when comparing total pressure drops before cleaning as shown in Table 5 since permeability is known to decline with use, leading to higher filtration pressure drops. Permeability reduction was generally attributed to infiltration of the porous ceramic structure by fine particulate, which accumulate and remain in the filter structure throughout the cleaning cycles. While an on-line reduction in filter permeability was recorded in the test program that paralleled this effort (Zeh, Chiang, and Ayers 1990), this phenomenon was not particularly evident here because of the relatively short test periods. Post-test evaluation of the candle filter used in this test series revealed a 98 reduction in permeability and a shift in large pore size to $53.95 \mu \mathrm{m}$ and in mean pore size to $39.66 \mu \mathrm{m}{ }^{4}$

4 P. Eggerstedt, Industrial Filter and Pump Manufacturing Company. January 20, 1989. Personal Communication with C. Zeh, METC. 


\subsection{CONCLOSIONS AND RECOMUNDATIONS}

made:

Based on the results of this testing, the following conclusions can be

- On average a $33 \%$ reduction in mean particle size by volume will produce a $498 \%$ increase in the dust-cake specific flow resistance, $k_{2}$.

- The magnitude of trends, particularly the effect of particle size on $K_{2}$, that will be seen in full-size filter applications can be predicted with a small-scale disc-filter test facility.

- The specific flow resistance of a specified dust cannot be absolutely predicted with a small-scale disc test facility.

- At least 24 hours are needed to condition a candle filter and form a residual dust cake.

- Thicker dust cakes can produce a higher specific flow resistance, $K_{2}$, most likely because of cake consolidation. This trend is much weaker than the effect of particle size on $K_{2}$.

- Increasing the face velocity will increase the $K_{2}$ value. This trend is seen to be much stronger for thin dust cakes than for thick cakes because thicker cakes may distribute the consolidation forces created by an increase in filtrate momentum.

- A reduction in particulate loading by a factor of five using cyclonic separation devices, accompanied by a corresponding reduction in particulate size distribution, will have a marginal effect (increased by 10 to 20 in. $\mathrm{H}_{2} \mathrm{O}$ ) on the overall pressure drop of the filtration system.

In conclusion, the following recommendations can be made for the par-ticulate removal system to be utilized at the Tidd PFBC. Cyclones should be removed from the flow stream, or the operational performance should be reduced, so that particulate with a larger mean size distribution is received at the filter. This design philosophy has been sipported by others (First 1984). The larger mean size reaching the filter will help reduce the $K_{2}$ value, produce a more desirable dust cake for cleaning purposes, and possibly reduce the overall pressure drop through the filter system.

An increase in pressure will not substantially affect the overall pressure drop through the filter system. This is true since even at higher pressure and mass flux, the Reynolds number is still less than 1.0 and the pressure drop is therefore, governed by viscous drag. While the higher operating pressure envisioned for the Tidd plant (177 psia) will increase the gas density and associated momentum, the overall effect should only be a 10 to 208 increase in $k_{2}$ because of the consolidation of the dust cake. Therefore, if a similar particulate morphology exists, and if a candle filter system is used without an excessive long-term reduction in filter permeability, we predict that the gas filtration system could be operated at a face velocity of $13 \mathrm{ft} / \mathrm{min}$, without upstream cyclones, and an approximate overall pressure drop of 4.5 psig. 


\subsection{NOMGNCLATURE}

$C_{D}$ Dust loading, $1 \mathrm{~b} / \mathrm{ft}^{3}$

D Particle diameter in Equations 5 and 6 , ft

$\boldsymbol{K}_{2}$ Dust cake specific resistance, in. $\mathrm{H}_{2} \mathrm{O} \cdot \mathrm{ft} \cdot \mathrm{min} / \mathrm{lb}$

N Number of particles per unit area, No./ $\mathrm{ft}^{2}$

$P_{d}$ Pressure drop through dust cake $\left(\mathrm{P}_{3}-\mathrm{P}_{2}\right)$, in. $\mathrm{H}_{2} \mathrm{O}$

$P_{0}$ Pressure drop through filter vessel without filter, in. $\mathrm{H}_{2} \mathrm{O}$

$P_{1}$ Same as $P_{0}$ but now with clean virgin filter in place, in. $\mathrm{H}_{2} \mathrm{O}$

$\mathbf{P}_{2}$ Pressure drop just after the filter has been cleaned, in. $\mathrm{H}_{2} \mathrm{O}$

$\mathbf{P}_{3}$ Pressure drop just before the filter has been cleaned, in. $\mathrm{H}_{2} \mathrm{O}$

Ro Particle density in Equations 5 and $6,1 \mathrm{~b} / \mathrm{ft}^{3}$

$T_{1}$ Time to form residual dust cake, $h$

$\mathbf{T}_{2} \quad$ Length of filtration cycle, $\mathrm{h}$

$v_{\text {f }}$ Superficial face velocity at filter, $\mathrm{ft} / \mathrm{min}$.

$w_{c}$ Areal density of dust cake, $1 \mathrm{~b} / \mathrm{ft}^{2}$

$W_{R}$ Weight of residual dust cake, $1 b$ 


\subsection{ABBREVIATIONS AND ACRONYMS}

\begin{tabular}{|c|c|}
\hline $\begin{array}{l}\text { ADACS } \\
\text { ATBC }\end{array}$ & $\begin{array}{l}\text { Automatic Data Acquisition and Control system } \\
\text { Atmospheric fluidized-bed combustor }\end{array}$ \\
\hline ASTM & American Society for Testing and Materials \\
\hline BET & Brunauer, Emmitt, Teller \\
\hline $\mathrm{Cr}$ & Candle filter \\
\hline Dr & Disc filter \\
\hline DOW & U.S. Department of Energy \\
\hline rI & Flow indicator \\
\hline $\mathbf{F T}$ & Fluid temperatures \\
\hline HT & Hemispherical temperature \\
\hline HTHP & High-temperature, high-pressure \\
\hline ID & Inside diameter \\
\hline IT & Initial deformation temperature \\
\hline TGT & Institute of Gas Technology \\
\hline $\mathbf{M}$ & Motor \\
\hline MatC & Morgantown Energy Technology Center \\
\hline OD & outside diameter \\
\hline PDT & Differential pressure indicator \\
\hline PFBC & Pressurized fiuidized-bed combustor \\
\hline RI & Pressure indicator \\
\hline SThM & Scanning electron microscope \\
\hline SS & Stainless steel \\
\hline ST & Softening temperature \\
\hline $\mathbf{T T}$ & Total filter \\
\hline TI & Tempe \\
\hline
\end{tabular}




\subsection{RETWRENCHS}

Collins, R.E. 1961. Flow of Eluids Through Porous Materials. New York: Reinhold Publishing Co.

First, M.W. April 1984, High-Temperature Gas Filtration Research Needs. DE-AC01-83FE60365, $89 \mathrm{p}$.

Helfritch, D.J. 1972. The Prediction of Baghouse Performance By Means of a Small Field Test Instrument. Buffalo, New York: Dustex Co.

Hillel, D. 1980. Fundamentals of Soll Physics. New York: Academic Press.

Holland, C.R., and E. Rothwell. 1977a. Model Studies of Fabric Dust Filtration. 1. Flow Characteristics of Dust Cakes Uniformly Distributed on Filter Fabrics. Filtration \& Separation January/February: 30-36.

Holland, C.R., and E. Rothwell. 1977b. Model Studies of Fabric Dust Filtration, 2. A Study of the Phenomena of Cake Collapse. Filtration \& Separation May/June: 224-231.

Institute of Gas Technology. February 1987. Institute of Gas Technology Hot Gas Cleanup Bench-Scale Unit. Unpublished report for METC under Contract No. DE-AC21-85UC22144.

Kunil, D., and O. Levenspiel. 1969. Fluidization Engineering. Malabar, Florida: Robert E. Krieger Publishing Co.

Leith, D., and R.W.K. Allen. 1986. Dust Filtration By Fabric Filterg, In Progress in Filtration \& Separation 4, R.J. Wakeman, ed., Amsterdam:

Elsevier Publishing Co., p. 1-51.

Miller, R.W. 1983. Flow Measurement Engineering Handbook. New York: McGraw Hill Co.

Pruce, L. 1981. Evaluating the Use of Coal, Ash Analyses For Predicting Fabric-Filter Performance, Power February: 80-83.

Rothwell, E. 1976. Concepts of Fabric Dust Filtration. Filtration \& Separation September/October: 477-484.

Rothwell, E. 1985. An Analysis of Fabric Dust Filtration I: Model Observations of Dust Cake Formation. Filtration \& Separation September/October: $317-324$.

Rothwell, E. 1986. An Analysis of Fabric Dust Filtration II: Computation of Constant Pressure-Drop Filtration. Filtration \& Separation March/April: 113-118. 
Sevilie, J.P.K., R. Clift, C.J. Withers, and W. Keldel. 1989. Rigid Ceramic Media for Filtering Hot Gases. Filtration \& Separation July/August:

265-271.

Tine, G. 1961. Gas Sampling and Chemical Analysis in Combustion Progesses. New York: Pergamon Press.

Vann Bush, P., T.R. Snyder, and R.L. Chang. 1989. Determination of Baghouse Performance From Coal and Ash Properties: Part 1, JAPCA 39: 228-237.

Vann Bush, P., T.R. Snyder, and W.B. Smith. 1987. Filtration Properties of Fly Ash From Fluidized-Bed Combustion, JAPCA 37: 1292-1297.

Zeh, C.M., T.K. Chiang, and W.J. Ayers. May 1990. Evaluation of Ceramic Candle Filter Performance in a Hot Particulate Laden stream, Technical Note. DOE/METC-90/4099. NTIS/DE90000483. 59 p. 


\section{Appendix A: Dust and Bed Material Data}

Appendix A includes the periodic mass measurements of dust and bed materital from cyclones 1 and 2 on the combustor exhaust (Cyc. 1 and CyC. 2 , respectively), the mass measurements of dust from the cyclone" system for the two configurations (Cyc. Sys. 1 and 2), and material removed from the overflow bed drain. All masses are recorded in grams and the time of day in hours. Most measurements were made every 2 hours, but some deviations exist. Footnotes to the data are listed below. Also included is a laboratory analysis of these samples.

(1) Testing started with a single primary cyclone in-line in the cyclone system. Candle filter test CF1 and disc filter tests DF1, DF2, and DF3 were conducted with this cyclone configuration $(5 / 16 / 89-5 / 20 / 89)$.

(2) The cyclone system was off-line for several hours while repairs were made to the candle filter flow control loop; consequently gas was not taken through the cyclone system.

(3) Testing started without a cyclone in the cyclone system; consequently the unaltered combustor effluent was sent to the filter vessel.s. Candle filter test CF2 and disc filter tests DF4, DF5, DF6, and DF7 were conducted with this configuration (5/16/89 - 5/20/89).

(4) Testing started with the single secondary cyclone in-line in the cyclone system. Candle filter test CF 3 and disc filter tests DF8, DF9, DF10, and DF11 were conducted with this cyclone configuration (5/23/89 - 5/26/89). 
Table 8. Material Removed from Cyclone System, AHBC Exhaust Cyclones, and Bed Overflow Drain

\begin{tabular}{|c|c|c|c|c|c|c|c|c|c|c|}
\hline \multirow[b]{2}{*}{ Date } & \multirow[b]{2}{*}{$\begin{array}{c}\text { Thime } \\
(\mathrm{h})\end{array}$} & \multicolumn{4}{|c|}{ Pertod to Dl acharge } & \multicolumn{4}{|c|}{ Dlsoharge Rater } & \multirow[b]{2}{*}{ Notes } \\
\hline & & $\begin{array}{c}\text { Cyolone } 1 \\
(\mathrm{~g})\end{array}$ & $\begin{array}{c}\text { Cyalone } 2 \\
(g)\end{array}$ & $\begin{array}{c}\text { Cyolone } \\
\text { syatem } \\
\text { (g) }\end{array}$ & $\begin{array}{c}\text { Overflow } \\
\text { Bed } \\
\text { Drain } \\
(g)\end{array}$ & $\begin{array}{c}\text { Cyolone } 1 \\
(\mathrm{~g} / \mathrm{h})\end{array}$ & $\begin{array}{c}\text { Cycl one ? } \\
(\mathrm{g} / \mathrm{h})\end{array}$ & $\begin{array}{c}\text { Cyclone } \\
\text { system } \\
(\mathrm{g} / \mathrm{h})\end{array}$ & $\begin{array}{c}\text { Overflow } \\
\text { Bed } \\
\text { Draln } \\
\text { (g/h) }\end{array}$ & \\
\hline $05 / 16 / 89$ & $\begin{array}{l}100 \\
300 \\
900 \\
700 \\
900 \\
1100 \\
1300 \\
1500 \\
1700 \\
1900 \\
2100 \\
2400\end{array}$ & $\begin{array}{l}580.5 \\
599.6 \\
626.5 \\
592.4 \\
596.7 \\
595.2 \\
584 \\
569.2 \\
629.4 \\
646.6 \\
798.3 \\
623.2\end{array}$ & $\begin{array}{l}27.5 \\
21.0 \\
10.1 \\
71 \\
31.6 \\
53.2 \\
39.7 \\
39.6 \\
37.2 \\
30.2 \\
53.5 \\
39.5\end{array}$ & $\begin{array}{l}596.1 \\
468.9 \\
414.7 \\
715.1 \\
657.3 \\
525.2 \\
686.4 \\
545.1 \\
631.5 \\
556.8 \\
372.8 \\
303.3\end{array}$ & $\begin{array}{l}1247.1 \\
1327.4 \\
1205.1 \\
1267.2 \\
1184.5 \\
1282.3 \\
1185.1 \\
1137.7 \\
1254.4 \\
1390.4 \\
1317.8 \\
1337.1\end{array}$ & $\begin{array}{l}290.3 \\
299.8 \\
313.3 \\
296.2 \\
298.4 \\
297.6 \\
292.0 \\
284.6 \\
314.7 \\
323.3 \\
399.2 \\
207.7\end{array}$ & $\begin{array}{r}13.8 \\
10.9 \\
5.1 \\
35.5 \\
15.8 \\
26.6 \\
19.9 \\
19.8 \\
18.6 \\
15.1 \\
26.8 \\
13.2\end{array}$ & $\begin{array}{l}298.1 \\
234.5 \\
207.4 \\
357.6 \\
328.7 \\
262.6 \\
343.2 \\
272.6 \\
315.8 \\
278.4 \\
186.4 \\
101.1\end{array}$ & $\begin{array}{l}623.6 \\
663.7 \\
602.6 \\
633.6 \\
592.3 \\
641.2 \\
592.5 \\
568.9 \\
627.2 \\
695.2 \\
658.9 \\
445.7\end{array}$ & (1) \\
\hline $05 / 17 / 89$ & $\begin{array}{r}200 \\
400 \\
600 \\
800 \\
1000 \\
1200 \\
1400 \\
1600 \\
1800 \\
2000 \\
2200 \\
2400\end{array}$ & $\begin{array}{l}635.1 \\
503.3 \\
61.3 .5 \\
711.5 \\
703 \\
703.6 \\
598.9 \\
606.6 \\
633 \\
655.2 \\
602.5 \\
199.7\end{array}$ & $\begin{array}{l}60.3 \\
33.7 \\
20.1 \\
40 \\
29.1 \\
33.7 \\
25.5 \\
35.4 \\
35.6 \\
29 \\
52.1 \\
21.6\end{array}$ & $\begin{array}{r}54 \theta .1 \\
702.6 \\
370.7 \\
637.2 \\
573.5 \\
25.4 \\
295.1 \\
739.4 \\
664.2 \\
776.3 \\
662 \\
634.8\end{array}$ & $\begin{array}{r}1567.3 \\
1270.8 \\
1445.9 \\
1347.3 \\
1251.1 \\
1211.4 \\
1231.9 \\
1340.7 \\
1403.2 \\
1605.9 \\
946.9 \\
1359.5\end{array}$ & $\begin{array}{r}317.6 \\
251.7 \\
306.8 \\
355.8 \\
351.5 \\
351.8 \\
299.5 \\
303.3 \\
316.5 \\
327.6 \\
301.3 \\
99.9\end{array}$ & $\begin{array}{l}30.2 \\
16.9 \\
10.1 \\
20.0 \\
14.6 \\
16.9 \\
12.8 \\
17.7 \\
17.8 \\
14.5 \\
26.1 \\
10.8\end{array}$ & $\begin{array}{r}274.1 \\
351.3 \\
185.4 \\
318.6 \\
286.8 \\
12.7 \\
147.6 \\
369.7 \\
332.1 \\
388.2 \\
331.0 \\
317.4\end{array}$ & $\begin{array}{l}783.7 \\
635.4 \\
723.0 \\
673.7 \\
625.6 \\
605.7 \\
616.0 \\
670.4 \\
701.6 \\
802.9 \\
473.5 \\
679.8\end{array}$ & \\
\hline $05 / 18 / 89$ & $\begin{array}{r}200 \\
400 \\
600 \\
800 \\
1000 \\
1200 \\
1400\end{array}$ & $\begin{array}{l}992.6 \\
613.8 \\
680.5 \\
772.3 \\
597.8 \\
618.8 \\
528\end{array}$ & $\begin{array}{l}21.6 \\
49.4 \\
29.6 \\
48.3 \\
47.4 \\
25.4 \\
49.7\end{array}$ & $\begin{array}{l}645.5 \\
321.4 \\
430 \\
224.7 \\
584.6 \\
493.6 \\
417.3\end{array}$ & $\begin{array}{r}1271.8 \\
1306.1 \\
1259.5 \\
1494.3 \\
1358.3 \\
1506.3 \\
878.7\end{array}$ & $\begin{array}{l}496.3 \\
306.9 \\
340.3 \\
386.2 \\
298.9 \\
309.4 \\
264.0\end{array}$ & $\begin{array}{l}10.8 \\
24.7 \\
14.8 \\
24.2 \\
23.7 \\
12.7 \\
24.9\end{array}$ & $\begin{array}{l}322.8 \\
160.7 \\
215.0 \\
112.4 \\
292.3 \\
246.8 \\
208.7\end{array}$ & $\begin{array}{l}635.9 \\
653.1 \\
629.8 \\
747.2 \\
679.2 \\
753.2 \\
439.4\end{array}$ & \\
\hline $05 / 19 / 89$ & $\begin{array}{r}400 \\
600 \\
700 \\
900 \\
1100 \\
1300 \\
1500 \\
1700 \\
1900 \\
2100 \\
2300\end{array}$ & $\begin{array}{r}1297.2 \\
757.5 \\
741.6 \\
918.9 \\
306.7 \\
484.9 \\
400.9 \\
480.1 \\
1250 \\
685.3 \\
699\end{array}$ & $\begin{array}{l}58.8 \\
48 \\
43.7 \\
38 \\
41.6 \\
28.8 \\
32.1 \\
23.4 \\
19.5 \\
43.6 \\
41.7\end{array}$ & $\begin{array}{l}663.8 \\
607.1 \\
603.5 \\
647.4 \\
343.4 \\
694.7 \\
464.5\end{array}$ & $\begin{array}{r}2544.7 \\
664.7 \\
489.9 \\
1325.1 \\
1439.5 \\
1398.5 \\
1316.1 \\
1617.2 \\
1537.3 \\
1389.7 \\
1428.4\end{array}$ & $\begin{array}{l}648.6 \\
378.8 \\
741.6 \\
459.5 \\
153.4 \\
242.5 \\
200.5 \\
240.1 \\
625.0 \\
342.7 \\
349.5\end{array}$ & $\begin{array}{l}29.4 \\
24.0 \\
43.7 \\
19.0 \\
20.8 \\
14.4 \\
16.1 \\
11.7 \\
9.8 \\
21.8 \\
20.9\end{array}$ & $\begin{array}{r}0.0 \\
0.0 \\
0.0 \\
0.0 \\
331.9 \\
343.6 \\
301.6 \\
323.7 \\
171.7 \\
347.4 \\
232.3\end{array}$ & $\begin{array}{r}1272.4 \\
332.4 \\
489.9 \\
662.6 \\
719.8 \\
699.3 \\
658.1 \\
808.6 \\
768.7 \\
694.9 \\
714.2\end{array}$ & (2) \\
\hline $05 / 20 / 89$ & $\begin{array}{r}100 \\
300 \\
500 \\
700 \\
900 \\
1100 \\
1300 \\
1500 \\
1700 \\
1900\end{array}$ & $\begin{array}{l}713.7 \\
922 \\
612.4 \\
529.7 \\
576.7 \\
577.2 \\
602.4 \\
642.4 \\
564.3 \\
1054.1\end{array}$ & $\begin{array}{l}67.6 \\
13.9 \\
42.9 \\
38.6 \\
23.8 \\
35.8 \\
20.9 \\
34.8 \\
28.4 \\
12.3\end{array}$ & $\begin{array}{l}756 \\
506.2 \\
762.9 \\
510 \\
450 \\
632 \\
588.6 \\
243.5 \\
737.5 \\
426.7\end{array}$ & $\begin{array}{l}1114.5 \\
1112.2 \\
1540.2 \\
1238.9 \\
1348.1 \\
1285.6 \\
1168.5 \\
1193.8 \\
1343.6 \\
1161.6\end{array}$ & $\begin{array}{l}356.9 \\
461.0 \\
306.2 \\
264.9 \\
208.4 \\
288.6 \\
301.2 \\
321.2 \\
282.2 \\
527.1\end{array}$ & $\begin{array}{r}33.8 \\
7.0 \\
21.5 \\
19.3 \\
11.9 \\
17.9 \\
10.5 \\
17.4 \\
14.2 \\
6.2\end{array}$ & $\begin{array}{l}378.0 \\
253.1 \\
381.5 \\
255.0 \\
225.0 \\
316.0 \\
294.3 \\
121.8 \\
368.8 \\
213.4\end{array}$ & $\begin{array}{l}707.3 \\
556.1 \\
770.1 \\
619.5 \\
674.1 \\
642.8 \\
584.3 \\
596.9 \\
671.8 \\
580.8\end{array}$ & \\
\hline $05 / 21 / 89$ & $\begin{array}{l}1200 \\
1400 \\
1600 \\
1800 \\
1900 \\
2100 \\
2300\end{array}$ & $\begin{array}{r}1845.7 \\
539.2 \\
890.8 \\
1250.5 \\
121 \\
382 \\
501\end{array}$ & $\begin{array}{r}117.1 \\
20.1 \\
71.7 \\
32.1 \\
101.1 \\
17.9 \\
24.7\end{array}$ & & $\begin{array}{r}5012.8 \\
1248.2 \\
1112.6 \\
1119.5 \\
765.5 \\
988.2 \\
1037.9\end{array}$ & $\begin{array}{l}922.9 \\
269.5 \\
445.4 \\
625.3 \\
121.0 \\
191.0 \\
250.5\end{array}$ & $\begin{array}{r}58.6 \\
10.1 \\
35.9 \\
15.1 \\
101.1 \\
9.0 \\
12.4\end{array}$ & $\begin{array}{l}0.0 \\
0.0 \\
0.0 \\
0.0 \\
0.0 \\
0.0 \\
0.0\end{array}$ & $\begin{array}{r}2506.4 \\
624.1 \\
556.3 \\
559.8 \\
765.8 \\
494.1 \\
519.0\end{array}$ & (3) \\
\hline
\end{tabular}


Table 8. Material Removed from Cyclone System, AFBC Exhaust Cyclones, and Bed Overflow Drain

(Continued)

\begin{tabular}{|c|c|c|c|c|c|c|c|c|c|c|}
\hline \multirow[b]{2}{*}{ Date } & \multirow[b]{2}{*}{$\begin{array}{c}\text { Time } \\
(\mathrm{h})\end{array}$} & \multicolumn{4}{|c|}{ Parlodle Dl scharge } & \multicolumn{4}{|c|}{ Dlocharge Rates } & \multirow[b]{2}{*}{ Notes } \\
\hline & & $\begin{array}{c}\text { Cyclone } 1 \\
\text { (g) }\end{array}$ & $\begin{array}{c}\text { Cyclone } 2 \\
\text { (g) }\end{array}$ & $\begin{array}{l}\text { Cyclone } \\
\text { System } \\
\text { (g) }\end{array}$ & $\begin{array}{c}\text { Overflow } \\
\text { Bod } \\
\text { Drain } \\
(g)\end{array}$ & $\begin{array}{c}\text { Cyclone } 1 \\
(g / h)\end{array}$ & $\begin{array}{c}\text { Cyclone } 2 \\
(y / h)\end{array}$ & $\begin{array}{c}\text { Cyclone } \\
\text { system } \\
(g / h)\end{array}$ & $\begin{array}{c}\text { Overflow } \\
\text { Bed } \\
\text { Drain } \\
(g / h)\end{array}$ & \\
\hline $05 / 22 / 89$ & $\begin{array}{r}130 \\
330 \\
500 \\
700 \\
900 \\
1000 \\
1200 \\
1600 \\
1800 \\
2000 \\
2200 \\
2400\end{array}$ & $\begin{array}{l}637.6 \\
541.8 \\
521.4 \\
743.7 \\
655.1 \\
326.1 \\
564.1 \\
672.1 \\
648.1 \\
659.1 \\
709.3 \\
947.1\end{array}$ & $\begin{array}{r}22.1 \\
23.3 \\
28.5 \\
48.9 \\
52.1 \\
22.4 \\
28.2 \\
71.2 \\
28.8 \\
41.7 \\
48.3 \\
104.7\end{array}$ & & $\begin{array}{l}1359 \\
1124.5 \\
1045.1 \\
1192.9 \\
1131.1 \\
605.5 \\
1046.2 \\
1042.8 \\
1191.2 \\
1105.1 \\
1218.7 \\
1274\end{array}$ & $\begin{array}{l}255.0 \\
270.9 \\
347.6 \\
371.9 \\
327.6 \\
326.1 \\
282.1 \\
168.0 \\
324.1 \\
329.6 \\
354.7 \\
473.6\end{array}$ & $\begin{array}{r}8.8 \\
11.7 \\
19.0 \\
24.5 \\
26.1 \\
22.4 \\
14.1 \\
17.8 \\
14.4 \\
20.9 \\
24.2 \\
52.4\end{array}$ & $\begin{array}{l}0.0 \\
0.0 \\
0.0 \\
0.0 \\
0.0 \\
0.0 \\
0.0 \\
0.0 \\
0.0 \\
0.0 \\
0.0 \\
0.0\end{array}$ & $\begin{array}{l}513.6 \\
562.3 \\
596.7 \\
596.5 \\
565.6 \\
605.5 \\
523.1 \\
260.7 \\
595.6 \\
552.6 \\
609.4 \\
637.0\end{array}$ & \\
\hline $05 / 23 / 89$ & $\begin{array}{r}200 \\
400 \\
600 \\
800 \\
1000 \\
1200 \\
1400 \\
1600 \\
1800 \\
2000 \\
2200 \\
2400\end{array}$ & $\begin{array}{c}1297.2 \\
1373.2 \\
1442.4 \\
1458.2 \\
1504.5 \\
1204.7 \\
970.5 \\
1373.7 \\
651 \\
392.1 \\
429.5 \\
515.7\end{array}$ & $\begin{array}{r}65.3 \\
30.8 \\
106.5 \\
68.4 \\
59.6 \\
44.5 \\
510.2 \\
24.3 \\
76 \\
21 \\
32.4 \\
29.7\end{array}$ & $\begin{array}{l}408.8 \\
737.4 \\
704\end{array}$ & $\begin{array}{l}976.2 \\
1099 \\
1179.8 \\
1167 \\
1269.1 \\
973.9 \\
1034.3 \\
1183.4 \\
1175 \\
1322.8 \\
1232.4 \\
1066.5\end{array}$ & $\begin{array}{l}648.6 \\
686.6 \\
721.2 \\
729.1 \\
752.3 \\
602.4 \\
485.3 \\
686.9 \\
325.5 \\
196.1 \\
214.8 \\
257.9\end{array}$ & $\begin{array}{r}32.7 \\
15.4 \\
53.3 \\
34.2 \\
29.8 \\
22.3 \\
255.1 \\
12.2 \\
38.0 \\
10.5 \\
16.2 \\
14.9\end{array}$ & $\begin{array}{r}0.0 \\
0.0 \\
0.0 \\
0.0 \\
0.0 \\
0.0 \\
0.0 \\
0.0 \\
0.0 \\
204.4 \\
368.7 \\
352.0\end{array}$ & $\begin{array}{l}488.1 \\
549.5 \\
589.9 \\
583.5 \\
634.6 \\
487.0 \\
517.2 \\
591.7 \\
587.5 \\
661.4 \\
616.2 \\
533.3\end{array}$ & (4) \\
\hline $05 / 24 / 89$ & $\begin{array}{r}200 \\
400 \\
600 \\
800 \\
1000 \\
1200 \\
1400 \\
1600 \\
1800 \\
1900 \\
2100 \\
2300\end{array}$ & $\begin{array}{l}550.7 \\
636 \\
604.8 \\
698.8 \\
724.9 \\
494.3 \\
615.6 \\
635.3 \\
661.1 \\
450.5 \\
590.2 \\
670.4\end{array}$ & $\begin{array}{l}30.9 \\
49 \\
36.6 \\
38.3 \\
30.8 \\
210.8 \\
11.9 \\
34.5 \\
36 \\
54.5 \\
18.4 \\
28.5\end{array}$ & $\begin{array}{l}732.3 \\
704 \\
335.5 \\
684.9 \\
653.5 \\
703.5 \\
695 \\
520.3 \\
677 \\
396.7 \\
735.4 \\
759.1\end{array}$ & $\begin{array}{r}1268.9 \\
1208.2 \\
981.2 \\
1085.1 \\
995.7 \\
789.3 \\
2096.1 \\
1018.9 \\
1195.2 \\
672.9 \\
1121.8 \\
650.7\end{array}$ & $\begin{array}{l}275.4 \\
318.0 \\
302.4 \\
349.4 \\
362.5 \\
247.2 \\
307.8 \\
317.7 \\
330.6 \\
450.5 \\
295.1 \\
335.2\end{array}$ & $\begin{array}{r}15.5 \\
24.5 \\
18.3 \\
19.2 \\
15.4 \\
105.4 \\
6.0 \\
17.3 \\
18.0 \\
54.5 \\
9.2 \\
14.3\end{array}$ & $\begin{array}{l}366.2 \\
352.0 \\
167.8 \\
342.5 \\
326.8 \\
351.8 \\
347.5 \\
260.2 \\
338.5 \\
396.7 \\
367.7 \\
379.6\end{array}$ & $\begin{array}{r}634.5 \\
604.1 \\
490.6 \\
542.6 \\
497.9 \\
394.7 \\
1048.1 \\
509.5 \\
597.6 \\
672.9 \\
555.9 \\
325.4\end{array}$ & \\
\hline $05 / 25 / 89$ & $\begin{array}{r}100 \\
300 \\
500 \\
700 \\
900 \\
1100 \\
1300 \\
1500 \\
1700 \\
1900 \\
2100 \\
2300\end{array}$ & $\begin{array}{l}700.9 \\
403.2 \\
774.1 \\
713.1 \\
669.3 \\
765.1 \\
649.1 \\
672.4 \\
504.4 \\
608.2 \\
670.7 \\
502.7\end{array}$ & $\begin{array}{r}25.9 \\
28.5 \\
21.2 \\
40.5 \\
29.3 \\
47.6 \\
38.8 \\
32.3 \\
38.6 \\
5.2 \\
204.6 \\
26.8\end{array}$ & $\begin{array}{l}725.7 \\
672.1 \\
637 \\
695.5 \\
695.8 \\
699.5 \\
613.5 \\
752.3 \\
580.9 \\
735.5 \\
846.7 \\
634.6\end{array}$ & $\begin{array}{l}1610.7 \\
1037 \\
1133.8 \\
1121.5 \\
1078.1 \\
1197.9 \\
1325.3 \\
1151.5 \\
1060.8 \\
1109.3 \\
1121.5 \\
1096.3\end{array}$ & $\begin{array}{l}350.5 \\
201.6 \\
387.1 \\
356.6 \\
334.7 \\
382.6 \\
324.6 \\
336.2 \\
252.2 \\
304.1 \\
335.4 \\
251.4\end{array}$ & $\begin{array}{r}13.0 \\
14.3 \\
10.6 \\
20.3 \\
14.7 \\
23.8 \\
19.4 \\
16.2 \\
19.3 \\
2.6 \\
102.3 \\
13.4\end{array}$ & $\begin{array}{l}362.9 \\
336.1 \\
318.5 \\
347.8 \\
347.9 \\
349.8 \\
306.8 \\
376.2 \\
290.5 \\
367.8 \\
423.4 \\
317.3\end{array}$ & $\begin{array}{l}805.4 \\
518.5 \\
566.9 \\
560.8 \\
539.1 \\
599.0 \\
662.7 \\
575.8 \\
530.4 \\
554.7 \\
560.8 \\
548.2\end{array}$ & \\
\hline $05 / 26 / 89$ & $\begin{array}{l}100 \\
300 \\
500 \\
700 \\
900\end{array}$ & $\begin{array}{l}628.8 \\
603.4 \\
630.6 \\
671.1 \\
751.1\end{array}$ & $\begin{array}{l}36.5 \\
28.3 \\
26.7 \\
16.8 \\
95.8\end{array}$ & $\begin{array}{l}588.6 \\
629.4 \\
677.8 \\
735.3 \\
393.7\end{array}$ & $\begin{array}{r}1009.1 \\
1054.1 \\
1230.8 \\
1151.4 \\
884.6\end{array}$ & $\begin{array}{l}311.4 \\
301.7 \\
315.3 \\
335.6 \\
375.6\end{array}$ & $\begin{array}{r}18.3 \\
14.2 \\
13.4 \\
8.4 \\
47.9\end{array}$ & $\begin{array}{l}294.3 \\
314.7 \\
338.9 \\
367.7 \\
196.9\end{array}$ & $\begin{array}{l}504.6 \\
532.1 \\
615.4 \\
575.7 \\
442.3\end{array}$ & \\
\hline
\end{tabular}


Table 9. Laboratory Analysis of Combustor Discharge Material,

Samples R20，R15，R16，R7-6, and R17

\begin{tabular}{|c|c|c|c|c|c|}
\hline \multirow[b]{2}{*}{ Parameter } & \multicolumn{5}{|c|}{ Sample Identification } \\
\hline & Bed Drain & Cyclone 1 & Cyclone 2 & $\begin{array}{l}\text { Cyclone } \\
\text { System } 1 \\
\end{array}$ & $\begin{array}{l}\text { Cyclone } \\
\text { System } 2\end{array}$ \\
\hline $\begin{array}{l}\text { Mean Particle Size } \\
\text { (by volume) ( } \mu \mathrm{m})\end{array}$ & 17.37 & 10.94 & 4.19 & 11.33 & 11.17 \\
\hline $\begin{array}{l}\text { Mean Particle Size (by } \\
\text { population }(\mu \mathrm{m})\end{array}$ & 4.76 & 3.72 & 1.90 & 3.76 & 3.65 \\
\hline $\begin{array}{l}\text { Density (by helium) } \\
\text { (g/cc) }\end{array}$ & 3.02 & 2.78 & 2.91 & 2.75 & 2.64 \\
\hline $\begin{array}{l}\mathrm{BET}^{1} \text { Surface Area (via } \\
\text { nitrogen }\left(\mathrm{m}^{2} / \mathrm{g}\right)\end{array}$ & 1.26 & 15.02 & 7.35 & 13.50 & 13.73 \\
\hline $\begin{array}{l}\text { Pore Volume, Adsorption } \\
\left(\text { via } \mathrm{N}_{2}\right)\left(\mathrm{cm}^{3} / \mathrm{g}\right)\end{array}$ & 0.0023 & 0.0086 & 0.0111 & 0.0080 & 0.0074 \\
\hline $\operatorname{Ash}\left(\frac{8}{8}\right)$ & 99.05 & 71.08 & 91.64 & 73.83 & 74.85 \\
\hline Carbon (z) & 0.52 & 25.57 & 4.82 & 21.10 & 22.09 \\
\hline Nitrogen $(8)$ & 0.01 & 0.45 & 0.11 & $<0.01$ & 0.36 \\
\hline Total Sulfur $(z)$ & 11.75 & 3.738 & 6.829 & 4.707 & 4.597 \\
\hline Sulfur $(z)$ & 8.08 & 1.91 & 2.55 & 2.52 & 2.42 \\
\hline Hydrogen $(z)$ & 0.24 & 0.26 & $<0.01$ & 0.15 & 0.22 \\
\hline Moisture (z) & 0.00 & 1.19 & 1.78 & 0.35 & 0.49 \\
\hline $\mathrm{K}_{2} \mathrm{O}(\mathrm{z})$ & 0.02 & 1.623 & 2.365 & 1.261 & 1.188 \\
\hline $\mathrm{SiO}_{2}(z)$ & 27.8 & 42.3 & 38.9 & 40.5 & 40.9 \\
\hline $\mathrm{Fe}_{2} \mathrm{O}_{3}(8)$ & 1.08 & 7.10 & 4.97 & 5.79 & 6.68 \\
\hline $\operatorname{Mgo}(z)$ & -- & 2.675 & 2.130 & 3.422 & 3.439 \\
\hline $\operatorname{Zno}\left(\frac{\gamma}{\gamma}\right)$ & 0.008 & 0.0061 & 0.0079 & 0.0104 & 0.0061 \\
\hline Sro $(z)$ & -- & 0.087 & 0.129 & 0.058 & 0.069 \\
\hline $\mathrm{CaO}(z)$ & 45.27 & 20.683 & 15.450 & 28.873 & 27.336 \\
\hline $\mathrm{P}_{2} \mathrm{O}_{5} \quad\left(\frac{8}{8}\right)$ & $<0.57$ & 0.331 & 0.285 & 0.405 & 0.391 \\
\hline $\mathrm{Al}_{2} \mathrm{O}_{3}$ & 5.04 & 17.89 & 19.13 & 15.88 & 14.97 \\
\hline $\mathrm{TiO}_{2}(8)$ & - & 0.68 & 0.90 & 0.45 & 0.48 \\
\hline $\mathrm{MnO}\left(\frac{f}{8}\right)$ & 0.00 & 0.002 & 0.000 & 0.005 & 0.004 \\
\hline
\end{tabular}

Brunauer, Emmit, Teller 
Appendix $B$ is a series of plots of the process variables made with ADACS. Similar plots were used to calculate experimental parameters needed to analyze the results. These particular plots were not used for the calculations because they include initial and final process values. Including the initial and final points (time before or after the actual test started or ended) would have lowered the mean value and increased the frequency of the minimum values. in other words, the statistics given on the top of each plot presented in Appendix $B$ may be slightly different than the values used in calculating $\mathrm{K}_{2}$ and face velocity.

The bottom header in each figure details the start and stop time of the plot, which is generally slightly longer then the actual test time so that end points could be included, and the skip factor, which indicates the number of raw data points skipped when collecting data for the plot. For instance, the ADACS system recorded data every 3 seconds, and if the skip factor was 05, then a real-time data point was plotted every 15 seconds. The abscissa is a time line and is plotted in hours. The ordinate is a line of magnitude and has units that are associated with each slot. The top header provides the slot number, units for that slot, and a slot description. Statistics are also provided that give the number of samples during the time of the plot, the mean, a standard deviation, and a minimum and maximum frequency of occurrence for the high and low values.

Slot descriptions are as follows:

- CANDLE FILTER HI FLOW - Total flow rate of filtrate through the candle filter.

- CANDLE FILTER DP -- Pressure drop across the candle filter.

- CANDLE FILTER INLET - Gas temperature in the pipe as gas enters the filter vessel.

- CANDLE FILTER TEMPERATURE -- Gas temperature 0.5 inches from the filter surface midway along the length.

- CANDLE FILTER OUTLET -- Gas temperature as gas exits the filter just above the tubesheet. (Note: In Figures 17, 22, and 27, candle-filter out let temperature is mistakenly referred to as patch-filter outlet temperature.)

- CANDLE FILTER FACE VELOCITY - Superficial gas velocity, based on the total filtrate flow, candle filter temperature, pressure in candle filter vessel, and the surface area of filter.

- ISO \#1 PRESSURE -- Candle filter vessel pressure. 


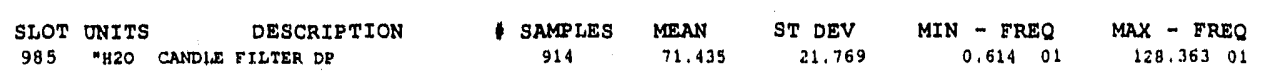

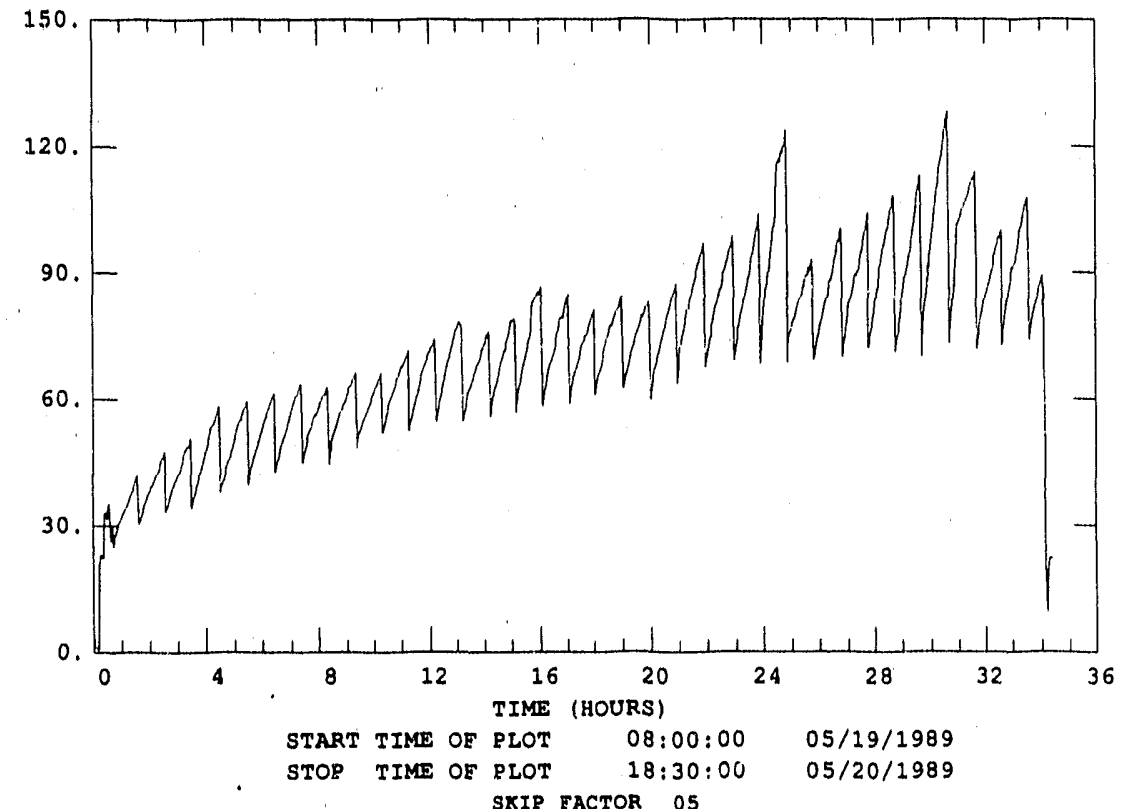

Figure 14. Pressure Drop Versus Time Signature for Candle Filter Test Cr1

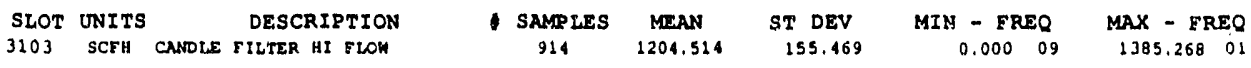

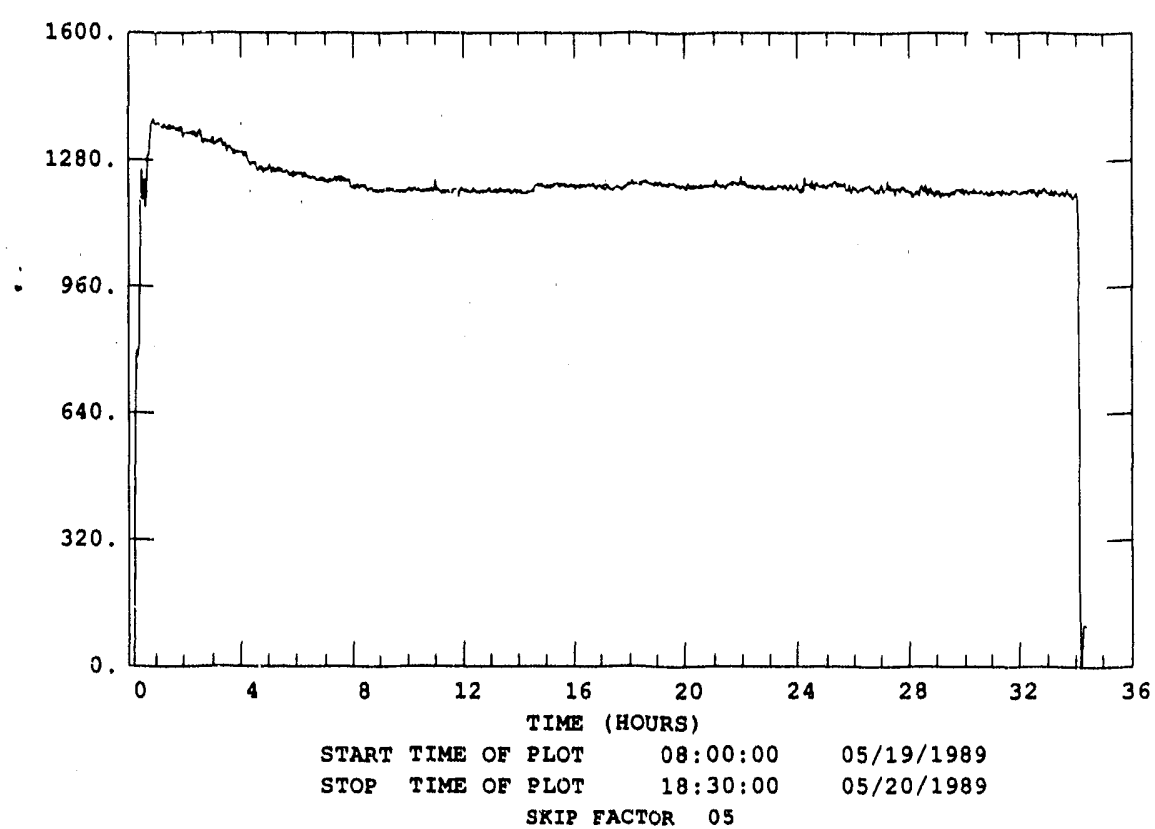

rigure 15. Filter rlow Rate Versus Time for Candle rilter Test Cr1 


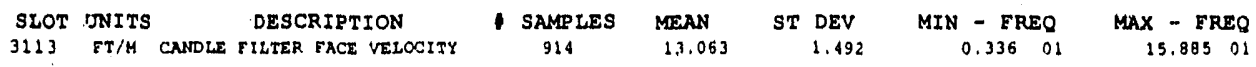

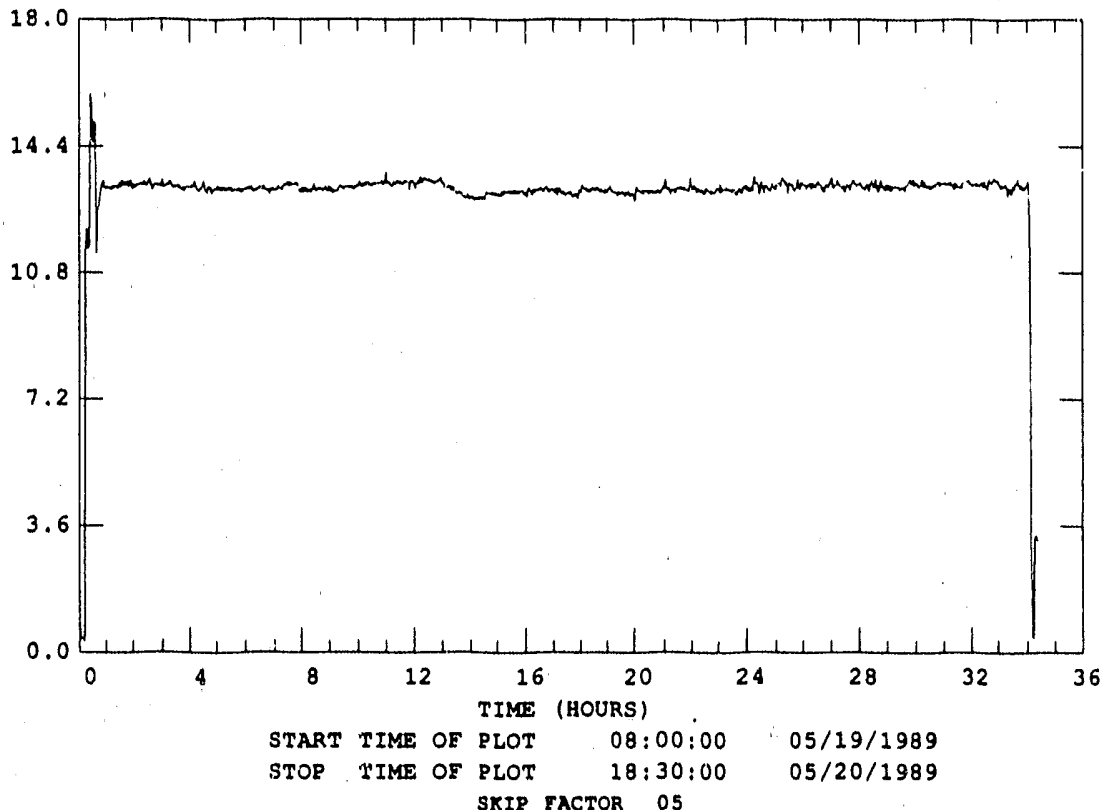

riguxe 16. Tilter race Velocity Versus Time for Candle rilter Test Cr1

\begin{tabular}{|c|c|c|c|c|c|c|c|c|c|c|c|}
\hline & SLOT & UNITS & \multicolumn{3}{|c|}{ DESCRIPTION } & - SAMPles & MEAN & \multirow{2}{*}{$\begin{array}{l}\text { ST DEV } \\
43,178\end{array}$} & \multicolumn{2}{|c|}{ MIN - FREQ } & MAX - EREQ \\
\hline & 929 & DEGF & CANOLLE & FILTER & INLET & 914 & 1233.414 & & 1624.504 & $0 !$ & $1355, \% 3401$ \\
\hline & 93 & DEGF & CANDLLE & FILTER & $R$ TERT. & 214 & 1328.504 & 62.339 & 1113.660 & vis & 1705.689 \\
\hline & & TEGF & PATCH E & FILTEF & WUTLET & 914 & 1242.008 & 279.011 & -5332.644 & $0 !$ & 1457.311 \\
\hline
\end{tabular}

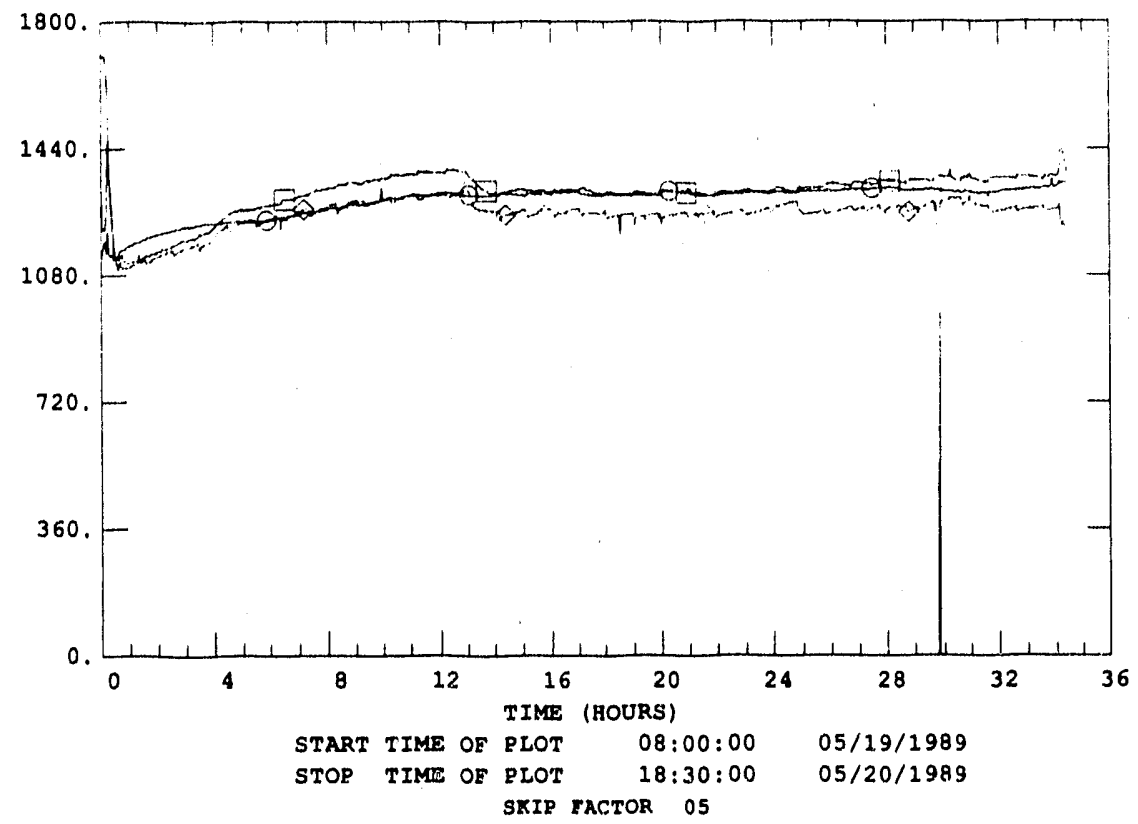

Iigure 17. Tiltrate Temperatures Versus Time for Candle rilter Test CF1 


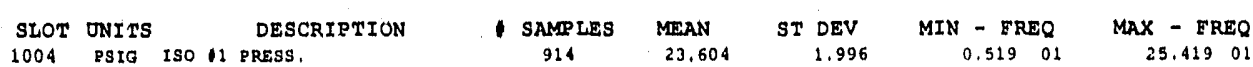
1004 PSIG ISO 11 PRESS.
$914 \quad 23,604$
1.996
0,51901
25.41901

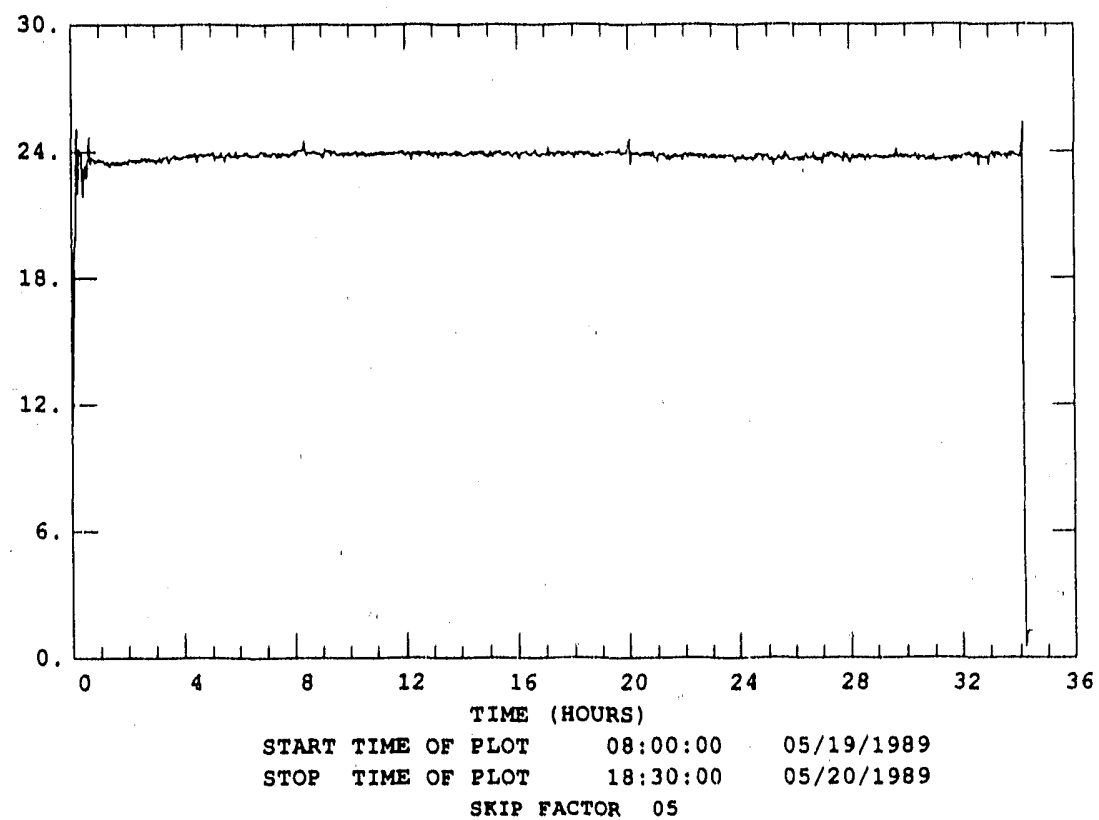

Figure 18. Candle rilter Vessel Pressure for Candle rilter Test Cr1

\begin{tabular}{|c|c|c|c|c|c|c|}
\hline 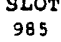 & $\begin{array}{l}\text { ONITS } \\
\text { "H2O }\end{array}$ & $\begin{array}{l}\text { DESCRIPTION } \\
\text { FILTER DP }\end{array}$ & $\begin{array}{c}\text { - SAMPLES } \\
128\end{array}$ & $\begin{array}{l}\text { MEAN } \\
39.586\end{array}$ & $\begin{array}{l}\text { ST DEV } \\
12.926\end{array}$ & $\begin{array}{c}I I N-E R E Q \\
0.347 \quad 01\end{array}$ \\
\hline
\end{tabular}

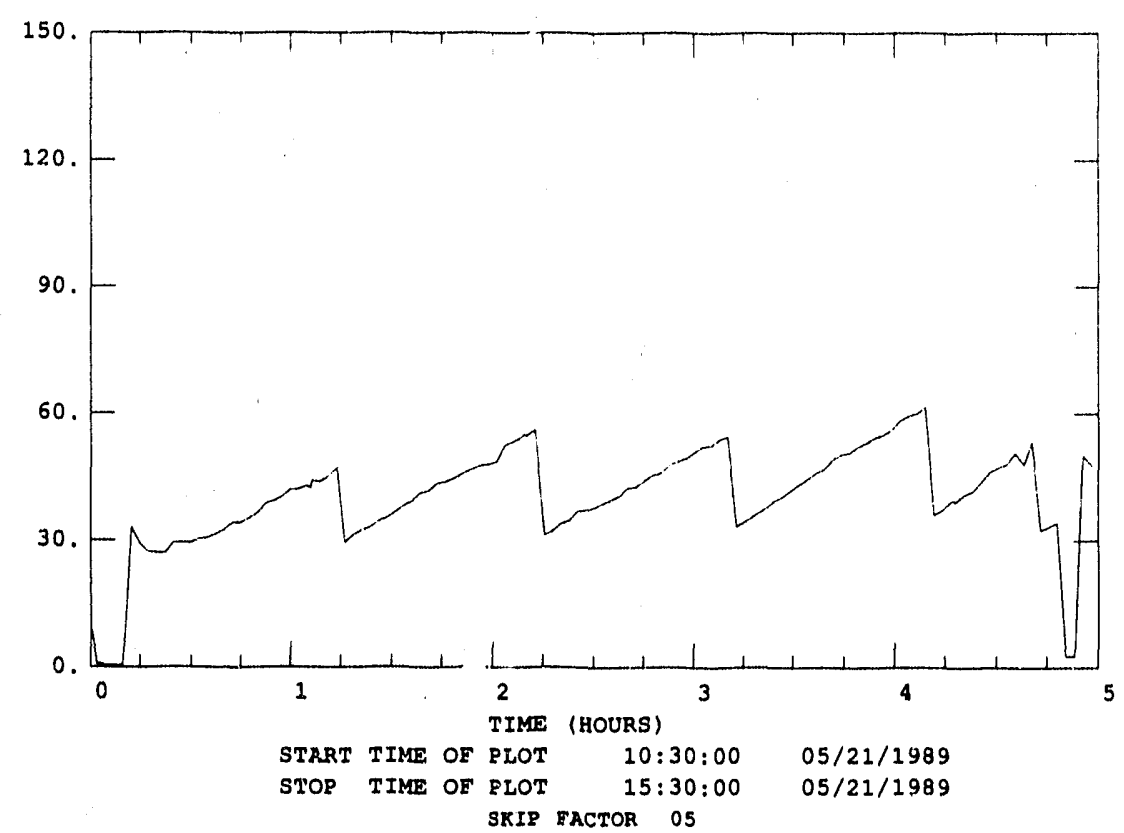

Tigure 19. Pressure Drop Versus Time Signature for Candle Filter Test Cr2 


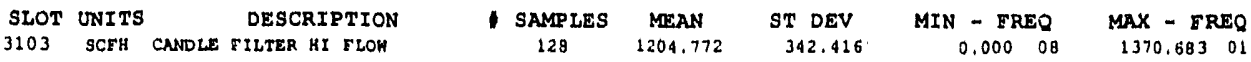

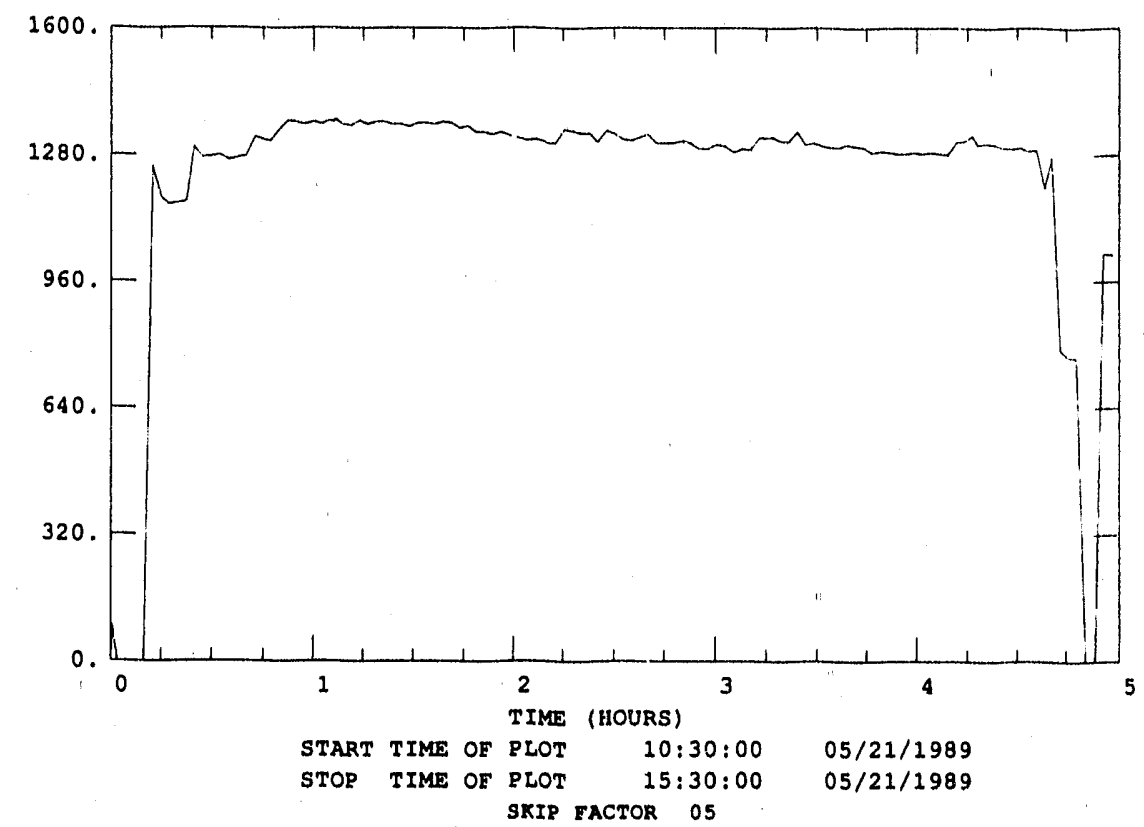

rigure 20. rilter rlow Rate Versus Time for Candle rilter Test Cr2

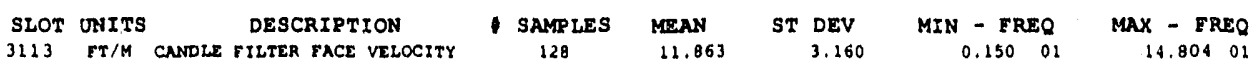

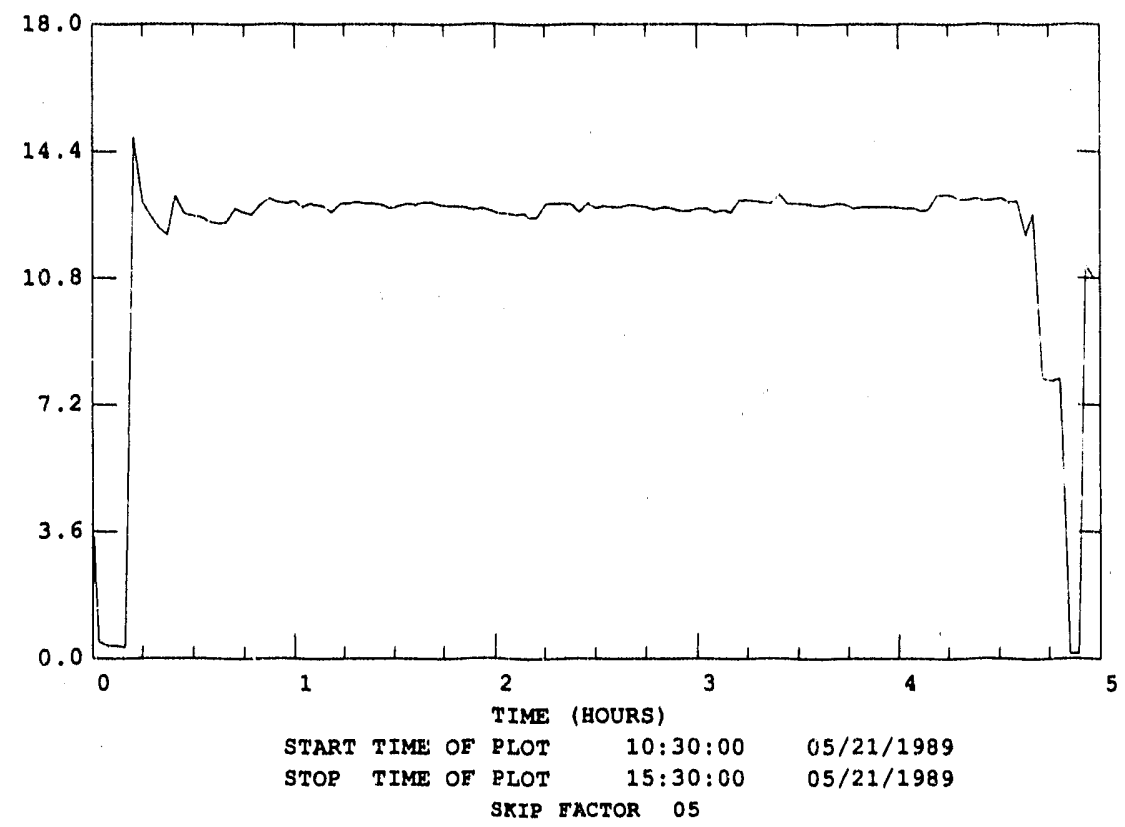

rigure 21. Filter race Velocity Versus Time for Candle Iilter Test Cr2 
DESCRIPTION

929 DEGF CANDLE NILTER INLET

- 95 DE DEG PATCHE FILTER TEMP.

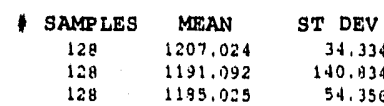

MIN - FREQ

1147,57202

$969.74901 \quad 1369.02401$

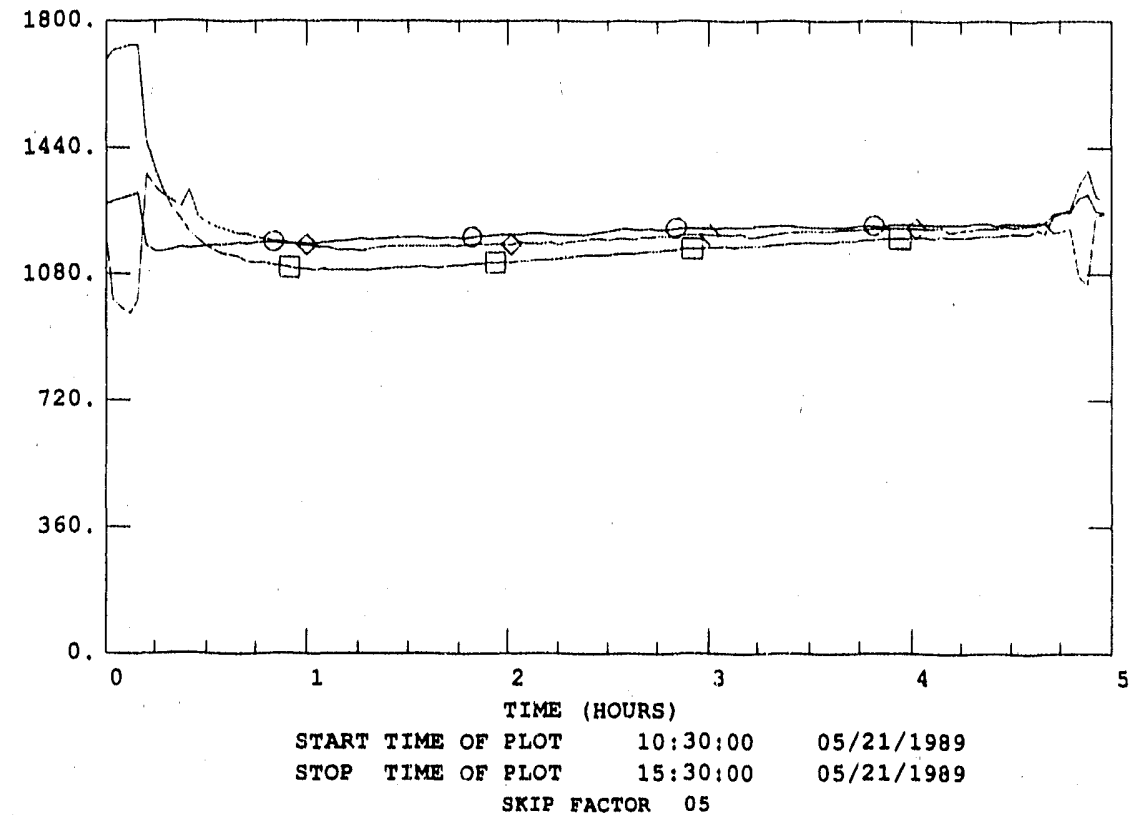

rigure 22. Tiltrate Temperatures Versus Time for Candle Tilter Test Cr2

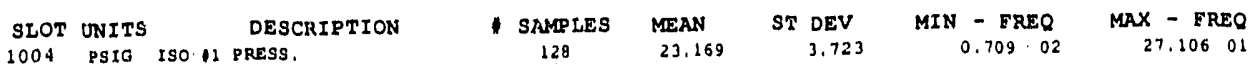

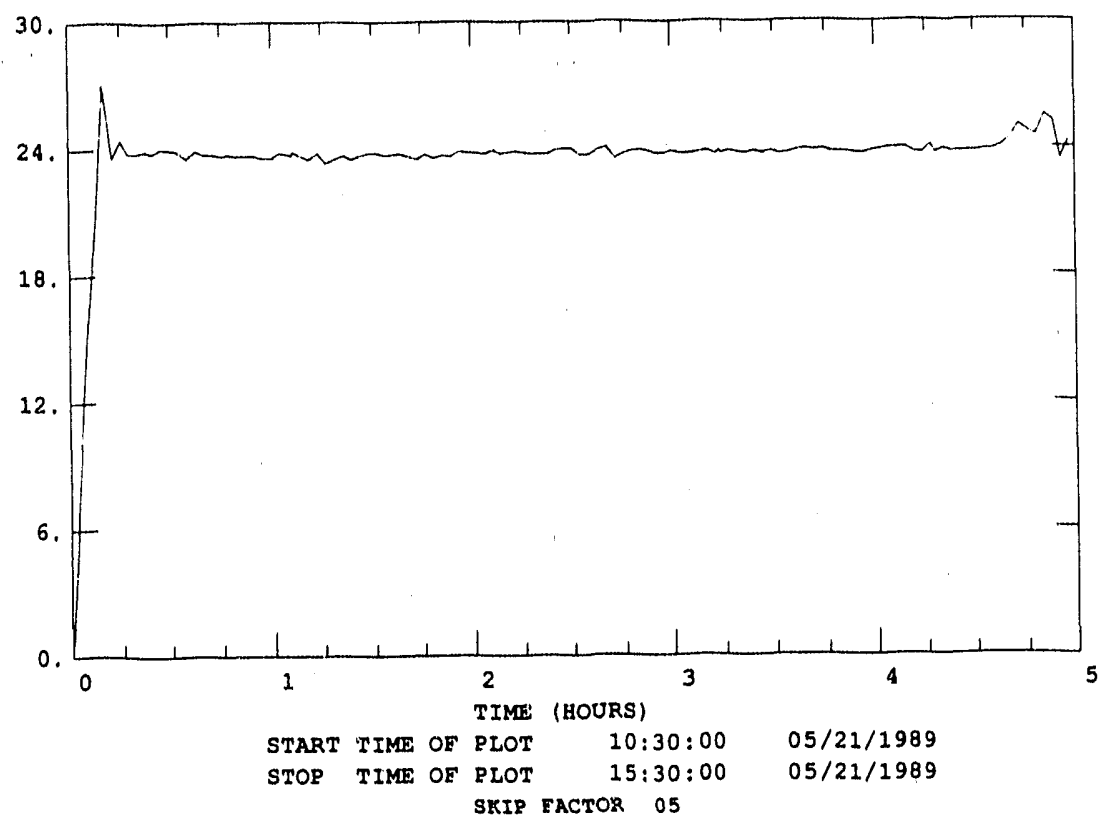

rigure 23. Candle Iilter Vessel Pressure for Candle rilter Test Cr2 

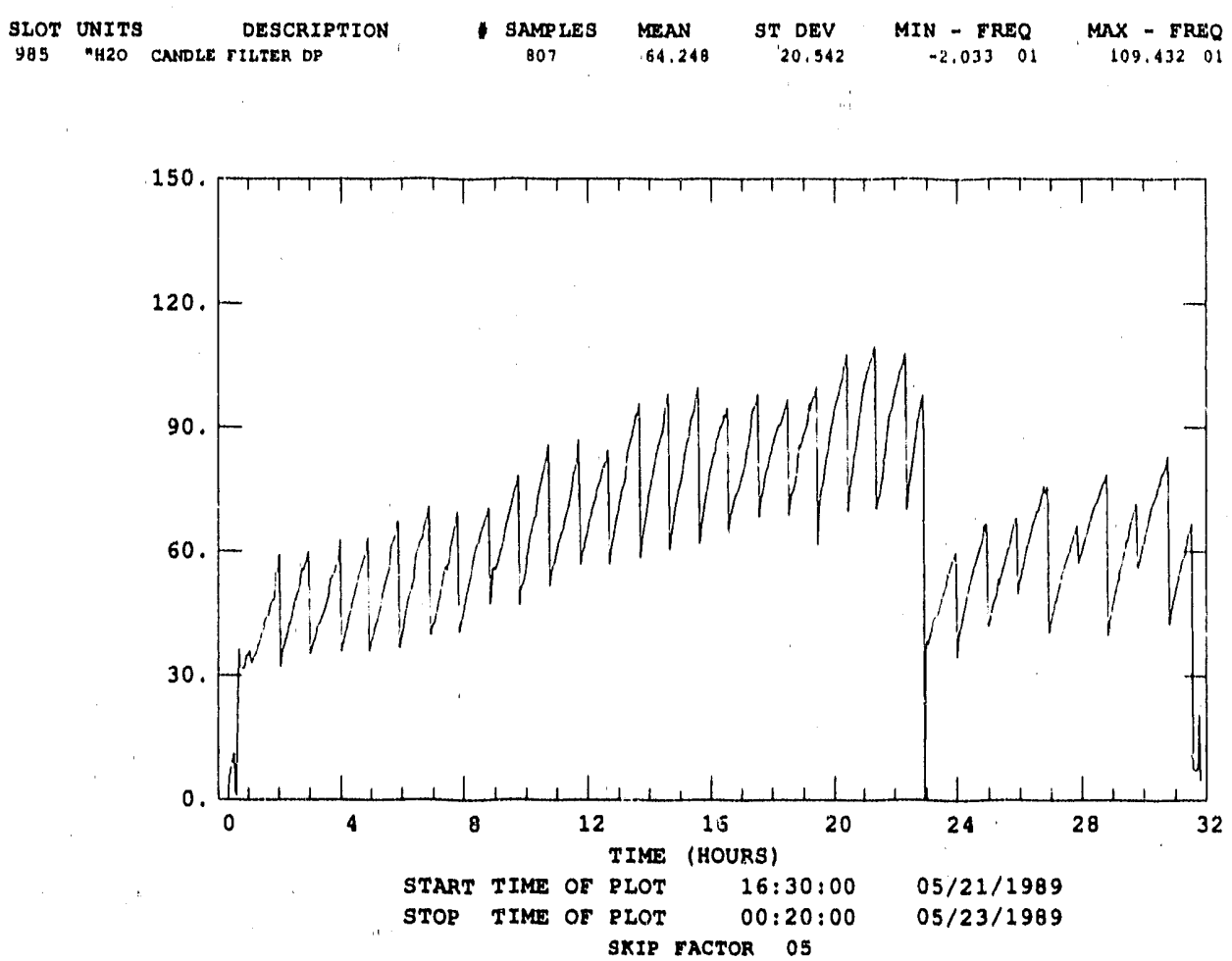

Figure 24. Bressure Drop Versus Time Signature for the Second Bart of Candle rilter Test Cr2

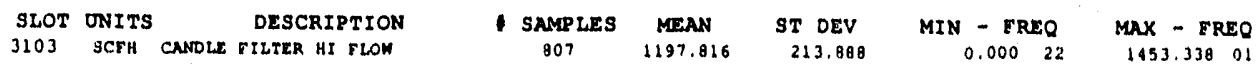

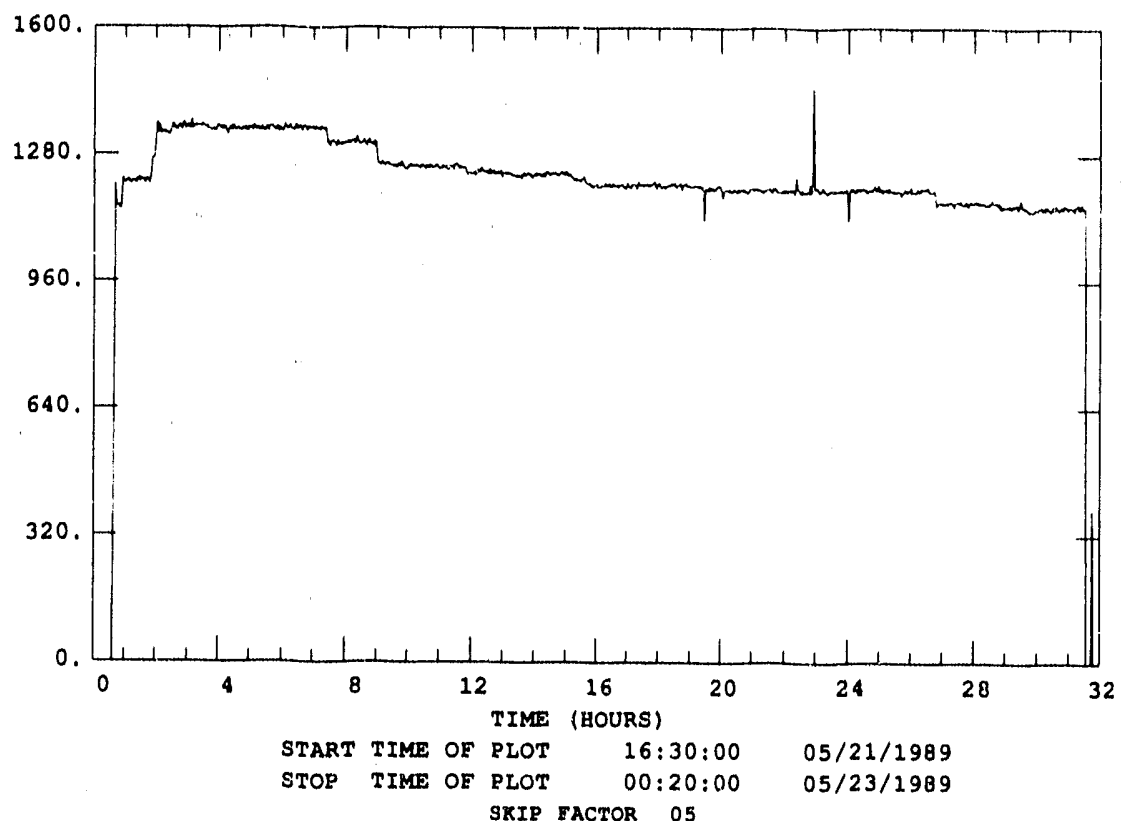

Tigure 25. Filter rIow Rate Versus Time for the Second Part of Candle rilter Test Cr2 


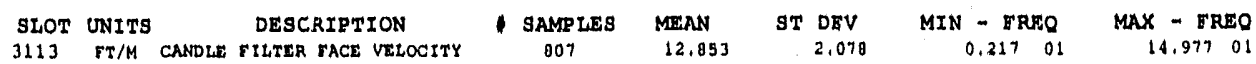

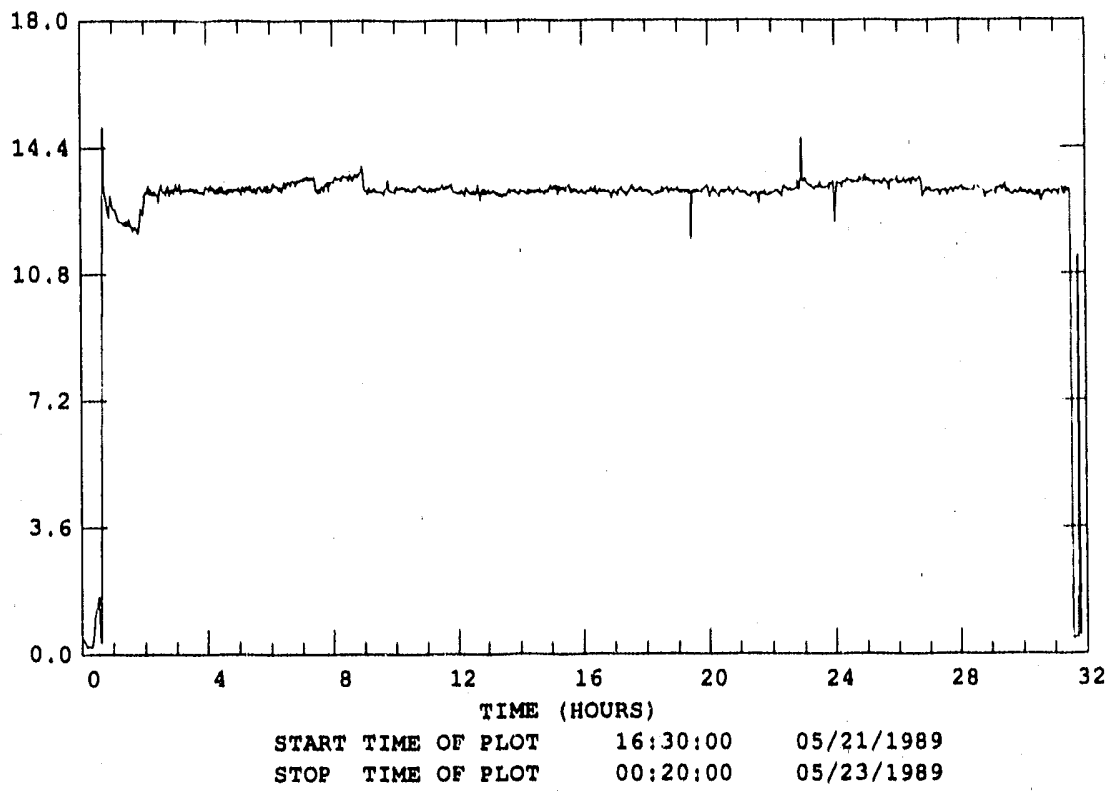

Tigure 26. Tilter race Velocity Versus Time for the Second Rart of Candle rilter Test Cr'2

\begin{tabular}{|c|c|c|c|c|c|c|c|}
\hline SLOT & UNITS & DESCRIPTION & - SAMPLES & MEAN & ST DEV & MIN - FREQ & EREQ \\
\hline 929 & DEGT & CANDLE FILTER INLET & 807 & 1264.325 & 23.971 & $1138.987 \quad 01$ & 1402,78401 \\
\hline 930 & DEGF & GANDLE TILTER TEMP. & 807 & 1316.776 & 111,843 & iil37.665 ol & 1759.55501 \\
\hline 458 & DEGF & PATCH FILTER JUTLET & 907 & 1207.408 & 83.249 & 907.77501 & $1365.750 \quad 01$ \\
\hline
\end{tabular}

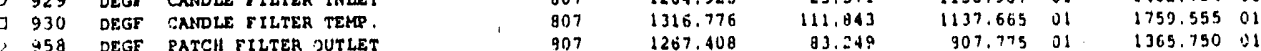

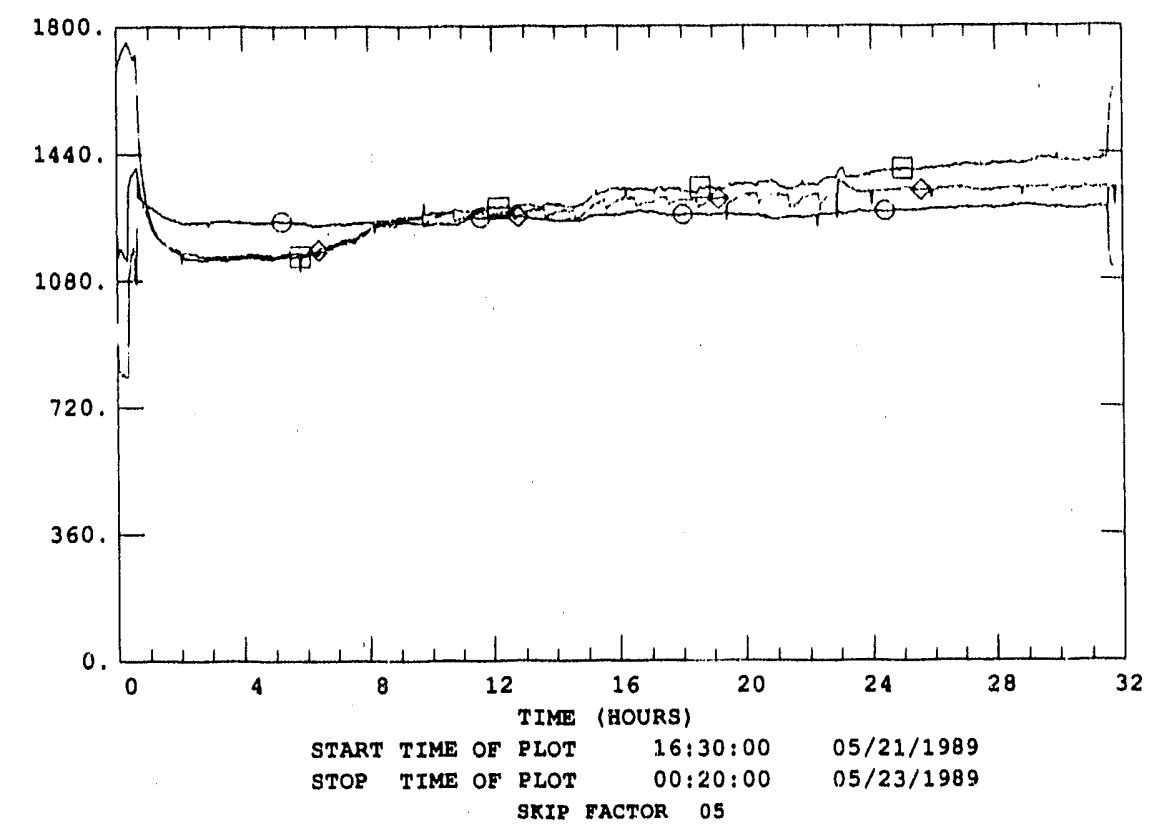

rigure 27. Tiltrate Temperature Versus Time for the Second Part of Candle rilter Test Cr2 


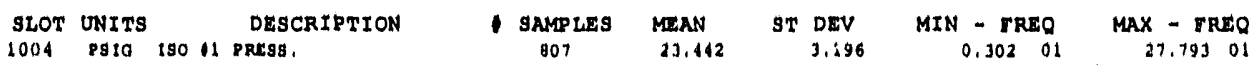

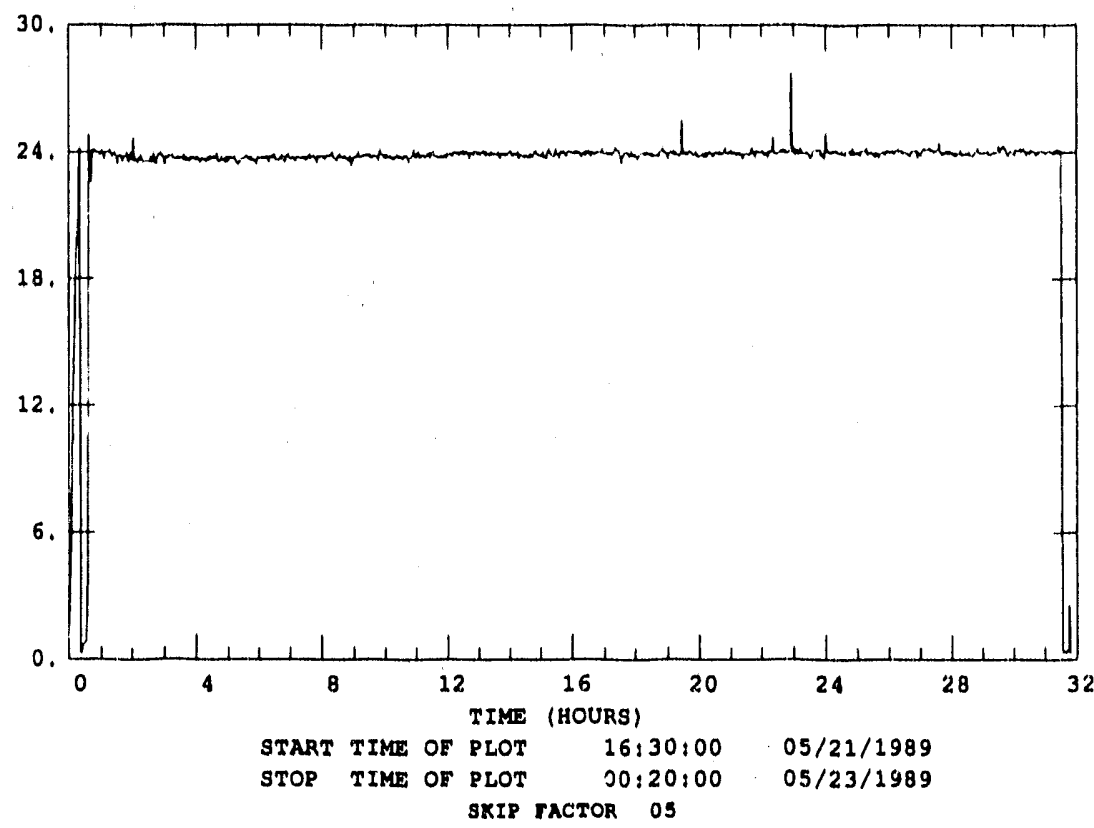

Tigure 28. Candle rilter Vessel Pressure for the Second Part of Candle rilter Teat $\mathrm{Cr} 2$

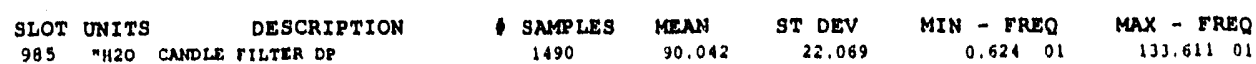

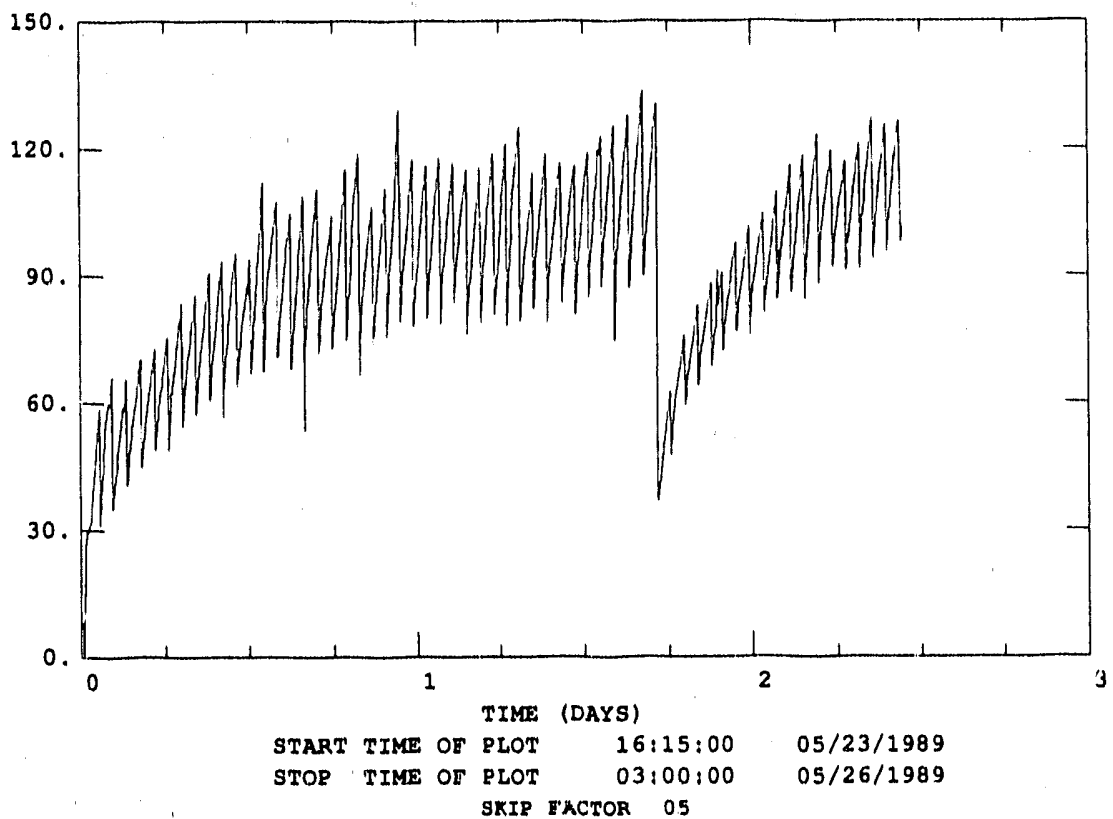

Figure 29. Pressure Drop Versus Time Signature for Candle Filter Test Cr3 


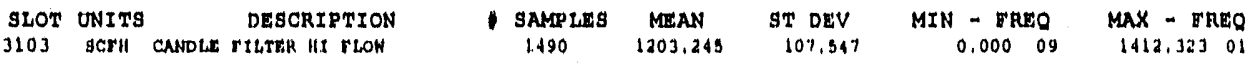

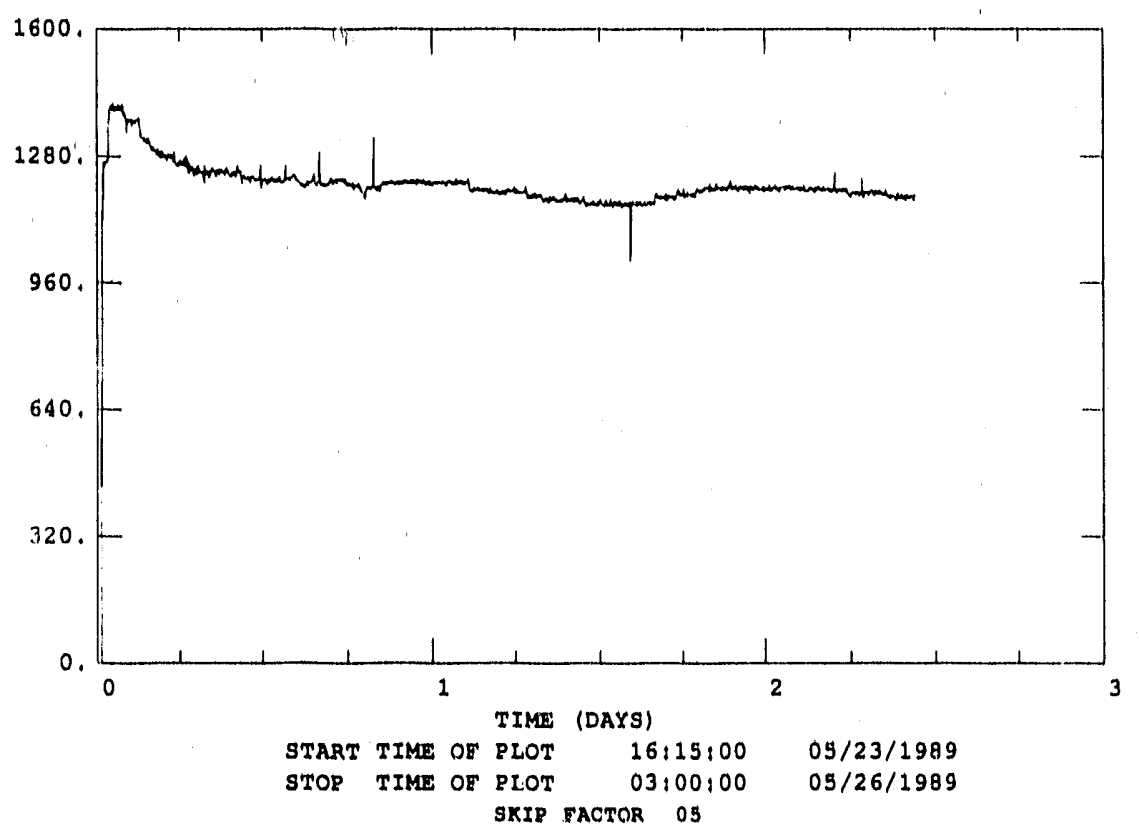

rigure 30. Filter rlow Rate Vorsus Time for Candle rilter Test Cr3

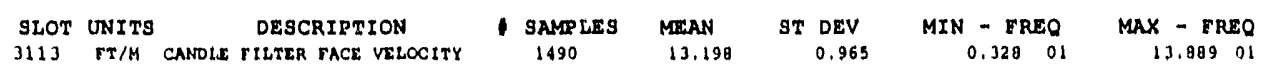

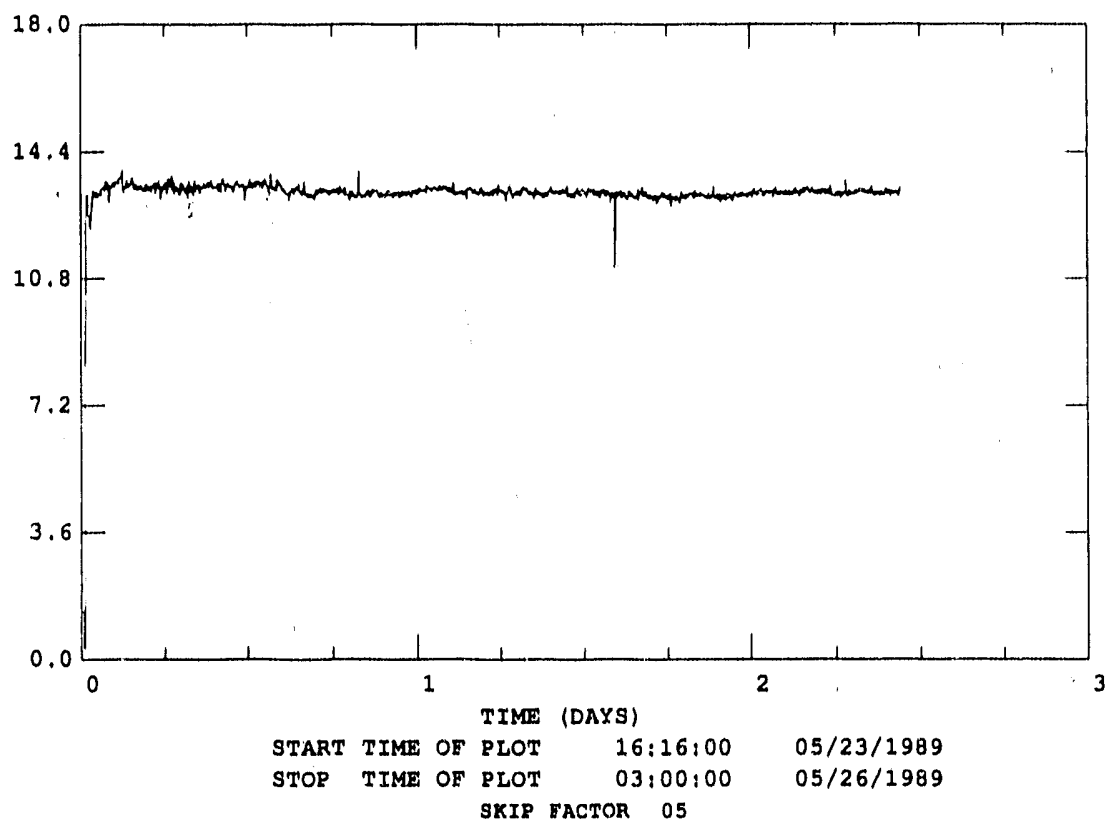

Figure 31. Filter race Velocity Versus Time for Candle rilter Test Cr3 


\begin{tabular}{|c|c|c|c|c|c|c|c|c|c|c|c|}
\hline SLOT & UNITS & & DEOC & CRIPTION & & SAMPLAS & MEAN & ST DEV & $M I N-r$ & TAEO & MAX - TREO \\
\hline 92 & Dear & CANOLE & rILTER & theET & $i^{\circ}$ & 1490 & 1292,714 & 19.272 & 1093,72 & 101 & 1184.29801 \\
\hline 93 & ocar & CANHELE & NiLTER & trats & & 1490 & $1339 .+43$ & 70.107 & 1936.980 & 102 & $169 \% .09 \mathrm{~A}$ \\
\hline (1) & near & TANOLX & ritter & TLET & & 1090 & $1307,27 \pi$ & $+2,701$ & $110 \mathrm{~A}, 201$ & 01 & 1179.010 \\
\hline
\end{tabular}

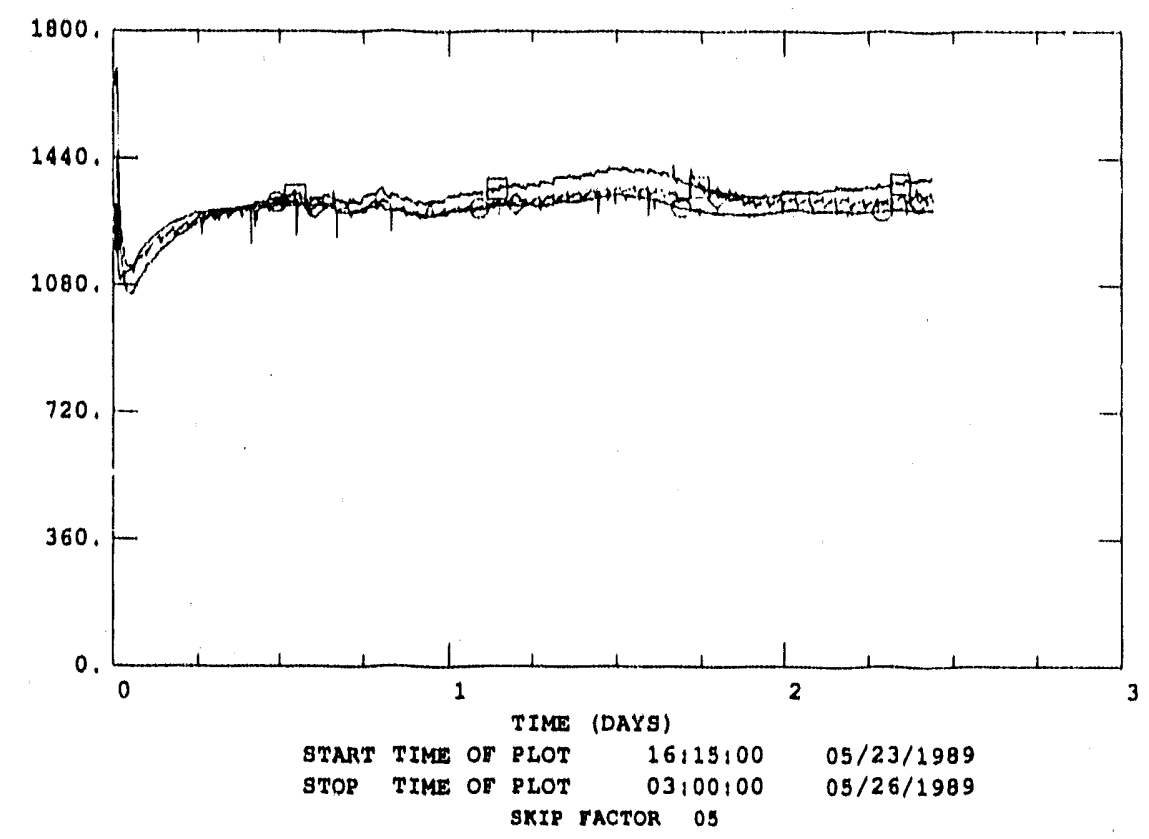

rigure 32. Tiltrate Temperatures Veraus Timo for Candle rilter Test cr3

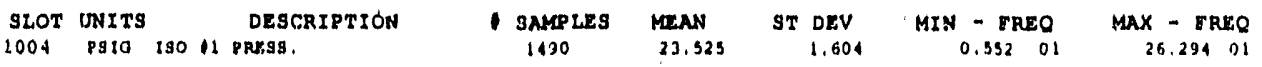

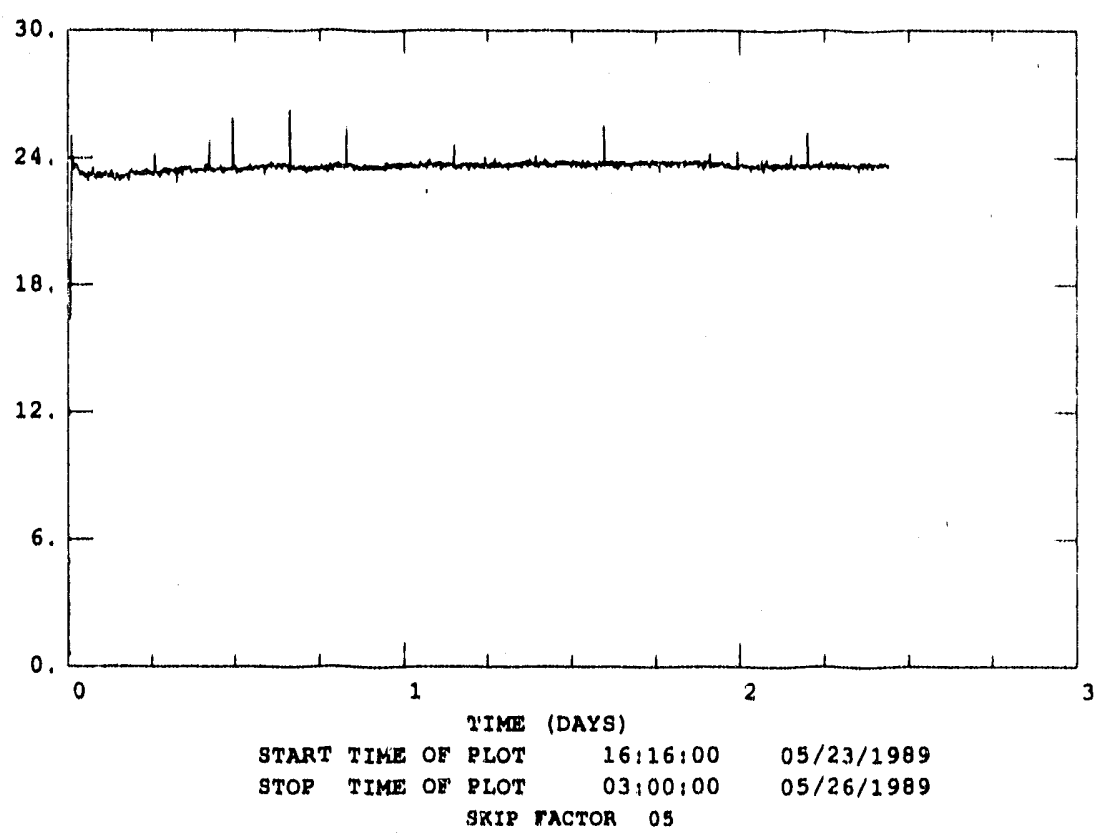

rigure 33. Candle rilter Vesmel Pressure for Candle rilter Test Cr3 


\section{Appendix C: Process Variable Plots for Diso-Filter Dust-Loading Tests Dr2}

Through Drit

Appendix $C$ is the series of ADACS plots that 1llustrate process parameters during the dust loading period of the disc filter test series. The meaning of the top and bottom headers are the same as in Appendix B. The slot numbers are different; however, the same approach was used to analyze the data and evaluate $K_{2}$. The data for Disc Filter Test 1 (DF1) was lost because of a computer hardware problem. Also included here is Table 10 containing a laboratory analysis of the disc filter dust cakes.

slot descriptions are as follows:

- PATCH FILTER DP -- Pressure drop across the disc filter.

- PATCH FILTER HIGH FLOW -- Total flow rate through the disc filter.

- PATCH FILTER FACE VELOCITY - Filter face velocity, based on the vessel pressure, candle filter outlet temperature, flow rate, and filter area.

- PATCH FILTER OUTLET - Temperature of the filtrate on the back side of the disc filter. (Note: In Figures 35, 38, 41, 44, 47, and 50, patchfilter outlet temperature is mistakenly referred to as candle-filter outlet temperature.)

- ISO \#2 PRESSURE - Disc filter vessel pressure. 
Table 10. Laboratory Analysis of Disc- Iilter Dust Cakes

\begin{tabular}{|c|c|c|c|c|c|c|c|c|c|c|c|}
\hline \multirow[b]{2}{*}{ Parameter } & \multicolumn{11}{|c|}{ Sample Itentiflcation } \\
\hline & $r \Gamma$ & DE2 & DF3 & DF4 & DF5 & DF6 & DF $7 *$ & DF8 & DF9 & DF10 & DF11 \\
\hline $\begin{array}{l}\text { Mean Particle Size } \\
\text { (by volume) }(\mu \mathrm{m})\end{array}$ & 7.07 & 4.30 & 6.58 & 6.44 & 9.62 & 8.89 & & 5.18 & 4.99 & 4.75 & 5.12 \\
\hline $\begin{array}{l}\text { Mean Particle Size } \\
\text { (by population) } \\
(\mu \mathrm{m})\end{array}$ & 3.58 & 2.05 & 2.11 & 2.18 & 3.31 & 3.25 & & 2.50 & 2.44 & 2.41 & 2.51 \\
\hline $\begin{array}{l}\text { Densiffy (by hellum) } \\
(\mathrm{g} / \mathrm{cm})\end{array}$ & 2.71 & 2.68 & 2.72 & 2.81 & 2.80 & 2.76 & & 2.74 & 2.74 & 2.66 & 2.69 \\
\hline $\begin{array}{l}\text { BEt }{ }^{\star \star} \text { Surface Area } \\
(v i a \text { nitrogen) } \\
\left(\mathrm{m}^{2} / g\right)\end{array}$ & 2.37 & 2.94 & 4.84 & 2.65 & 2.28 & 3.15 & & 3.20 & 2.86 & 3.36 & 3.15 \\
\hline $\begin{array}{l}\text { Pore Volume, } \\
\text { Adsorption (vfa } \\
\text { nitrogen) }(\mathrm{cm} / \mathrm{g})\end{array}$ & 0.0053 & 0.0056 & 0.0090 & 0.0056 & 0.0046 & 0.0069 & & 0.0063 & 0.0081 & 0.0061 & 0.0048 \\
\hline Ash (y) & 97.38 & 98.63 & 96.00 & 96.78 & 96.42 & 95.64 & & 97.50 & 98.48 & 99.37 & 96.54 \\
\hline Carbon (8) & 0.65 & 0.57 & 1.36 & 1.24 & 1.65 & 1.45 & & 0.57 & 0.57 & 0.22 & 1.55 \\
\hline Nitrogen (z) & 0.09 & $<0.01$ & $<0.01$ & $<0.01$ & 0.02 & 0.03 & & $<0.01$ & 0.02 & $<0.01$ & 0.03 \\
\hline Total sulfur (t) & 8.809 & 8.751 & 8.31 .4 & 6.922 & 5.956 & 6.059 & & 10.096 & 8.48 & 9.599 & 9.69 \\
\hline Sulfux (t) & 5.83 & 5.79 & 5.85 & 5.24 & 4.99 & 4.37 & & 6.70 & 5.60 & 6.48 & 6.17 \\
\hline Hydrogen (f) & 0.03 & 0.18 & 0.04 & 0.06 & 0.02 & 0.12 & & 0.01 & 0.01 & 0.09 & 0.06 \\
\hline Molsture (z) & 0.12 & 0.18 & 0.08 & 0.24 & 0.14 & 0.11 & & 0.48 & 0.24 & 0.22 & 0.18 \\
\hline$K_{2} \cap(t)$ & 2.165 & 2.362 & 2.079 & 1.815 & 1.781 & 1.820 & & 2.105 & 2.13 & 2.197 & 2.06 \\
\hline $\sin _{2}(\theta)$ & 38.0 & 37.1 & 38.5 & 39.0 & 39.5 & 40.1 & & 34.9 & 35.0 & 35.2 & 35.6 \\
\hline $\mathrm{Fe}_{2} \mathrm{O}_{3}(t)$ & 5.34 & 4.85 & $5.0^{\circ}$ & 5.76 & 5.98 & 5.53 & & 5.08 & 4.92 & 4.17 & 4.53 \\
\hline $\operatorname{MgO}(4)$ & 2.107 & 2.132 & 2.191 & 2.298 & 2.327 & 2.459 & & 1.512 & -- & 1.594 & -- \\
\hline $\operatorname{lno}(8)$ & 0.0110 & 0.0153 & 0.0093 & 0.0086 & 0.0065 & 0.0100 & & 0.0065 & 0.008 & 0.0085 & 0.008 \\
\hline sro (t) & 0.084 & 0.098 & 0.075 & 0.059 & 0.055 & 0.066 & & 0.126 & -- & 0.145 & - \\
\hline $\mathrm{CaO}(t)$ & 15.368 & 15.095 & 16.514 & 19.045 & 18.840 & 19.501 & & 12.516 & 13.07 & 12.407 & 14.86 \\
\hline $\mathrm{P}_{2} \mathrm{O}_{3}(8)$ & 0.275 & 0.268 & 0.290 & 0.314 & 0.310 & 0.321 & & 0.2 .53 & 0.26 & 0.257 & - \\
\hline $\mathrm{Al}_{2} \mathrm{O},(t)$ & is 97 & 18.55 & 19.06 & 18.35 & 18.90 & 18.98 & & 18.97 & 18.79 & 19.31 & 18.40 \\
\hline $\mathrm{THO}_{2}(\mathrm{H})$ & 0.34 & 0.93 & 0.80 & 0.69 & 0.70 & 0.72 & & 1.01 & - & 1.01 & - \\
\hline MnO (f) & 0.014 & 0.010 & 0.002 & 0.017 & 0.017 & 0.000 & & 0.007 & 0.00 & 0.000 & 0.005 \\
\hline Ash Fuston IT $\left({ }^{\circ} \mathrm{F}\right)$ & 2,145 & -- & 2,150 & 2,280 & 2,305 & 2,190 & & 2,175 & 2,245 & 2,190 & 2,195 \\
\hline Ash Fusion ST $\left({ }^{\circ} \mathbf{F}\right)$ & 2,210 & -- & 2,310 & 2,375 & 2,380 & 2,290 & & 2,260 & 2,340 & 2,350 & 2,295 \\
\hline Ash Fuston HT $\left({ }^{\circ} \mathrm{F}\right)$ & 2,230 & -- & 2,330 & 2,420 & 2,400 & 2,310 & & 2,285 & 2,380 & 2,390 & 2,315 \\
\hline Ash rusion $\mathrm{FT}\left({ }^{\circ} \mathrm{F}\right)$ & 2,290 & -- & 2,375 & 2,485 & 2,475 & 2,405 & & 2,390 & 2,500 & 2,460 & 2,410 \\
\hline
\end{tabular}

* Sample DF7 lost.

** BET - Brunauer, Emitt, Teller. 


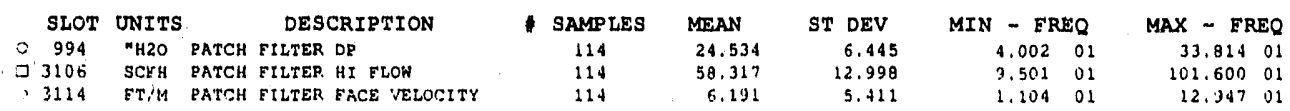

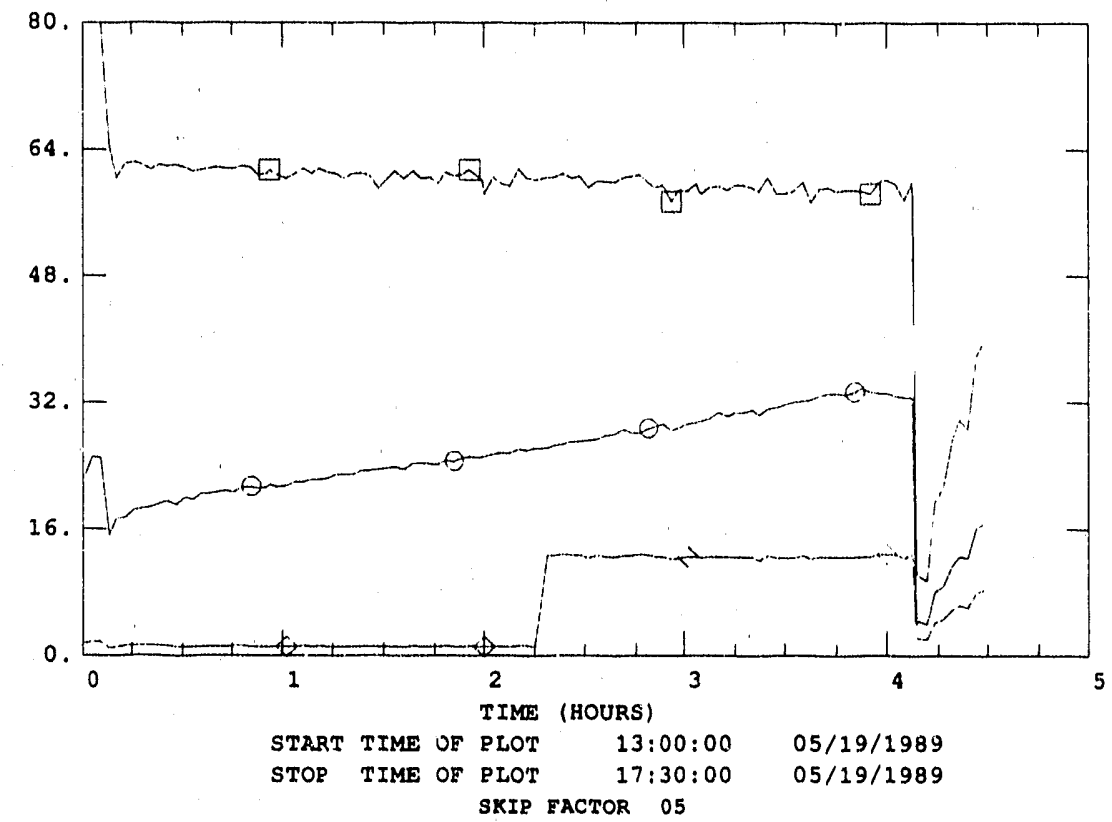

rigure 34. Pressure Drop, Flow Rate, and race Velocity Duxing Disc Filter Test Dr2

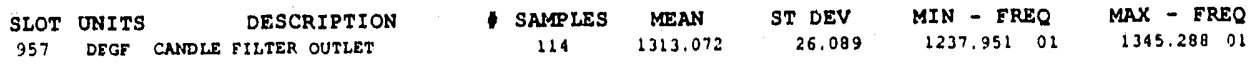

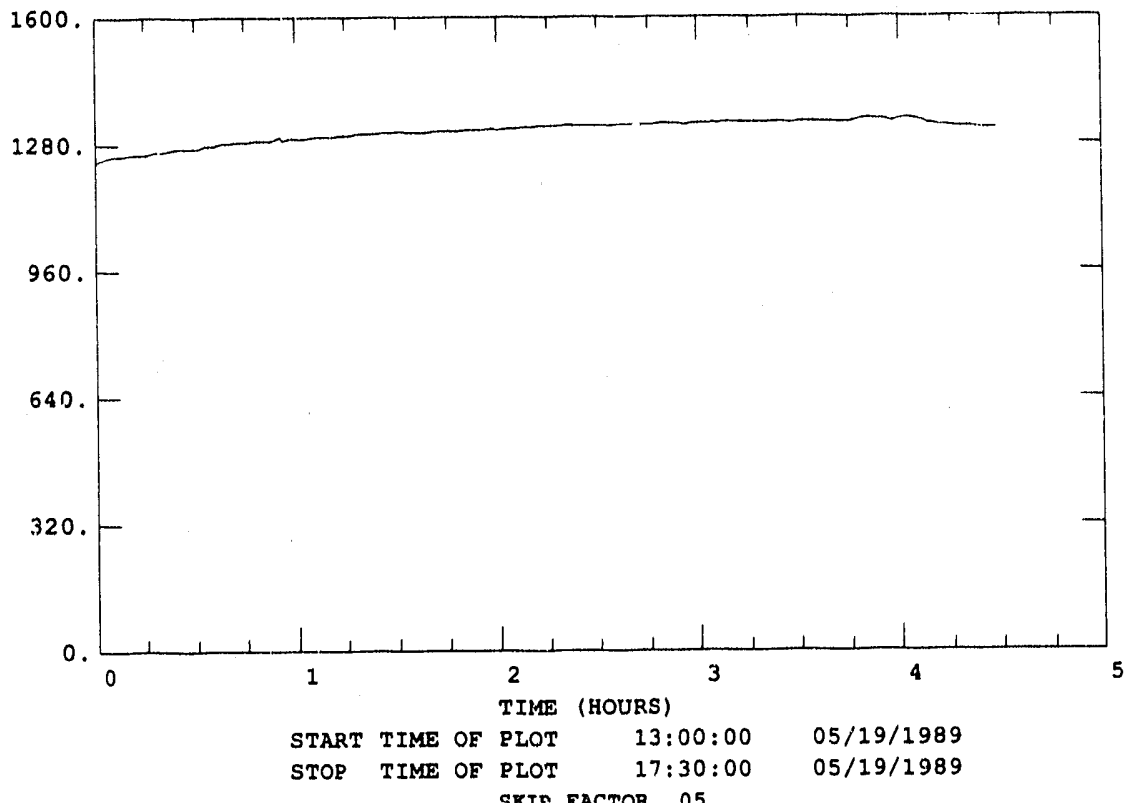

rigure 35. Disc Filter Outlet Temperature During Disc Filter Test Dr2 
SLOT UNITS DESCRIPTION
1005 PSIG ISO 2 PRESS.

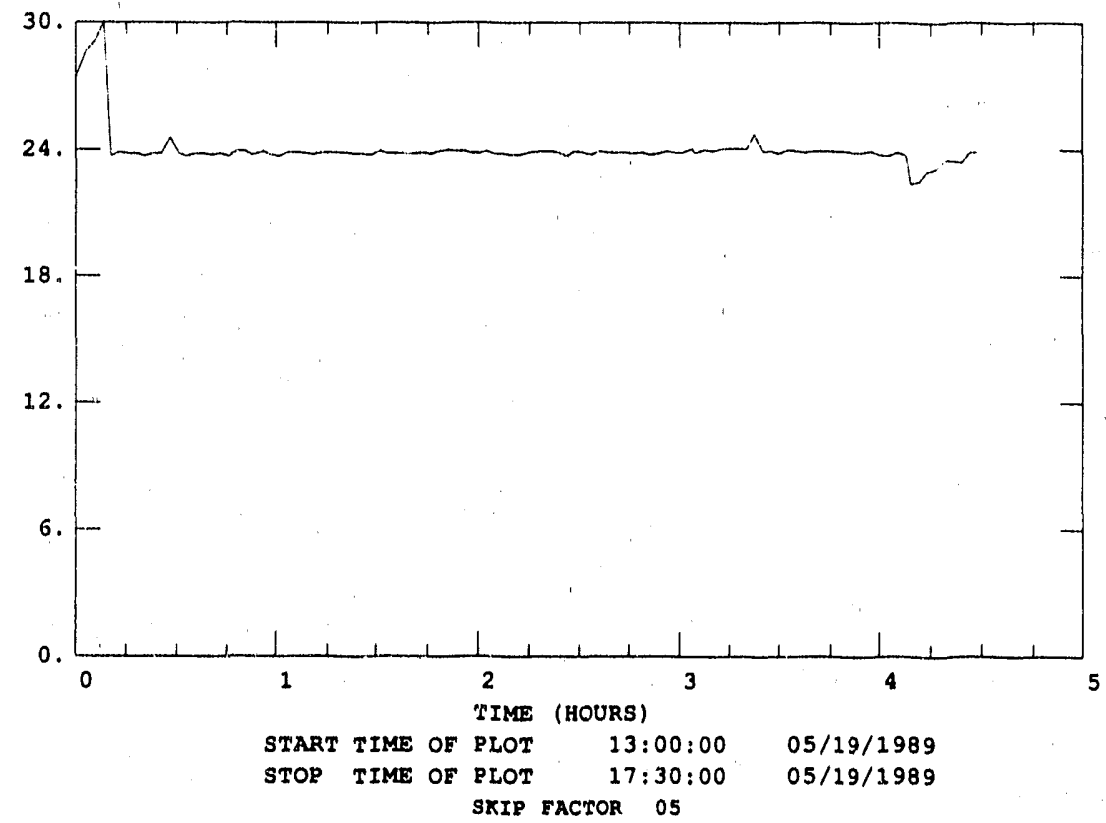

rigure 36. Disc rilter Vessel pressure During Disc Filter Test Dr2

\begin{tabular}{|c|c|c|c|c|c|c|c|c|c|}
\hline SLO & UNITS & & DESCRIPTION & - SAMPLES & MEAN & ST DEV & $M I N-E I$ & & MAX - FREQ \\
\hline & ${ }^{-} \mathrm{H}_{2} \mathrm{O}$ & РАTCH & FILTER DP & 362 & 478 & 21,181 & 1.093 & 01 & $94.250 \quad 01$ \\
\hline 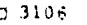 & SCFH & PATCH & FILTER HI FLOW & 362 & 54.901 & 9.000 & n. 124 & 01 & 92.015 \\
\hline 3 & FTiM & FATCH & FILIEK FACE VELOITY & $30:=$ & 13.753 & $4: 2+5$ & -38.500 & 01 & $\therefore 9.390$ \\
\hline
\end{tabular}

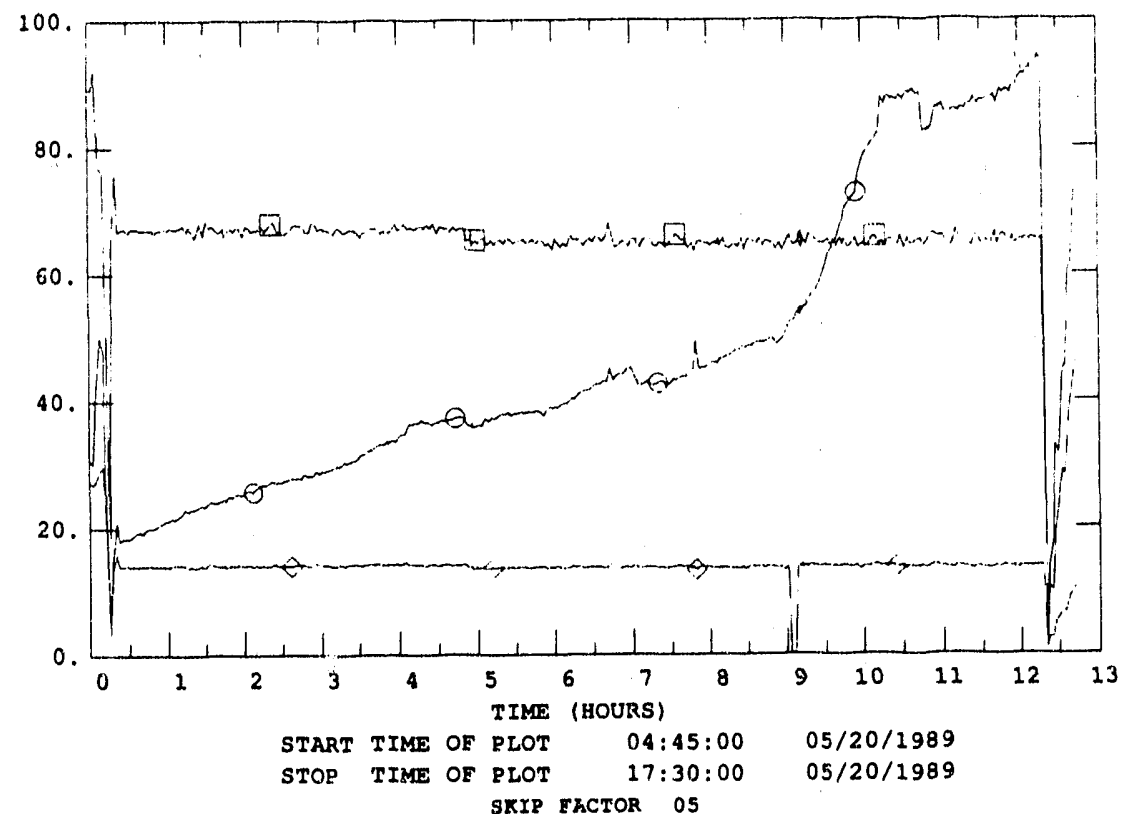

rigure 37. Pressure Drop, Flow Rate, and Face Velocity During Disc Filtex Test Dr3 


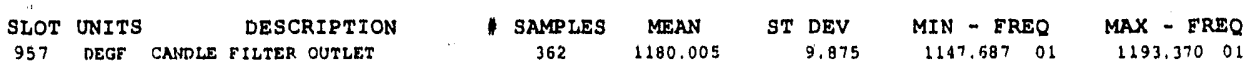

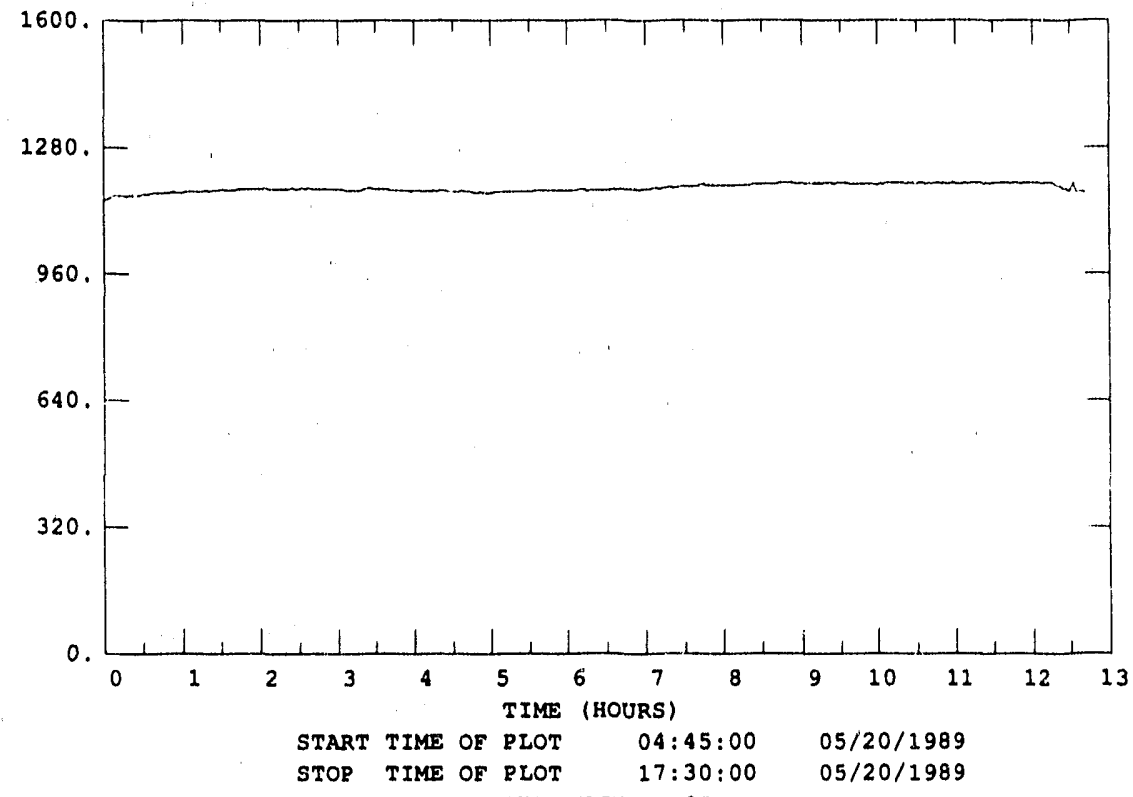

Figure 38. Disc riltex Outlet Temperature During Disc rilter Test Dr3

SLOT UNITS DESCRIPTION
1005 PSIG ISO 12 PRESS.

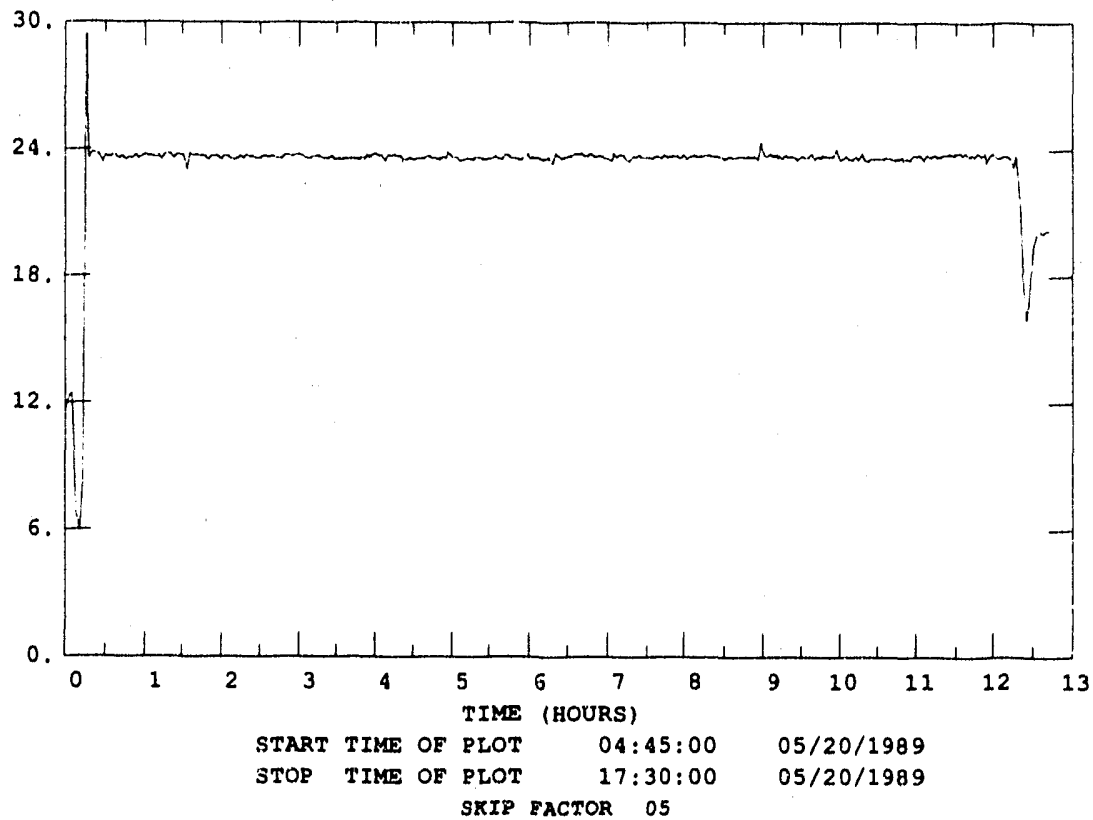

rigure 39. Disc Tilter Pressure During Disc Filter Test Dr3 


\begin{tabular}{|c|c|c|c|c|c|c|c|c|c|c|}
\hline SLOT & UNITS & & DES & CRIPTION & SAMPLES & MEAN & ST DEV & $M I N-E F$ & & $\operatorname{MAX}$ - EREQ \\
\hline 994 & " $\mathrm{H} 2 \mathrm{O}$ & PATCH & FILTER & $D P$ & 19 & 12.570 & 8.393 & -0.965 & 01 & 20.48901 \\
\hline $3100^{\circ}$ & $\mathrm{SCFH}$ & PATCH & FILTER & HI ELOW & 19 & +3.114 & 25.833 & 6.863 & UI & $63.732 \quad 01$ \\
\hline 31: & FTiM & PATEH & Filiter & FACE VELOCITY & is & 8.743 & 5.155 & 1.204 & 01 & $12.831,11$ \\
\hline
\end{tabular}

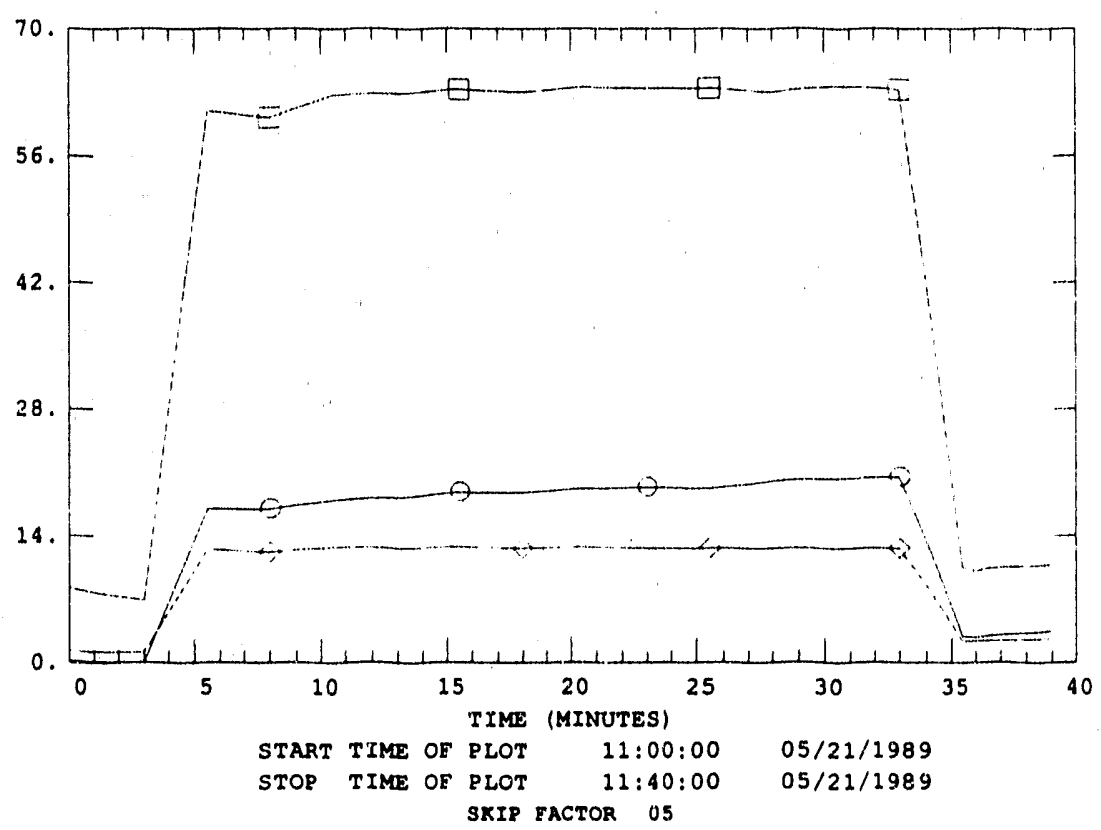

Figure 40. Pressure Drop, Flow Rate, and Face Velocity During Disc rilter Test DIA

$\begin{array}{lcccccc}\text { SLOT UNITS } & \text { DESCRIPTION } & \text { SAMPLES } & \text { MENN } & \text { ST DEV } & \text { MIN - FRYQ } & \text { MAX - FREQ } \\ \text { 757 DEGF CANDLE FILTER JUTLET } & 63 & 1188.253 & 7.367 & 1172.400 & 01 & 1199.645\end{array}$

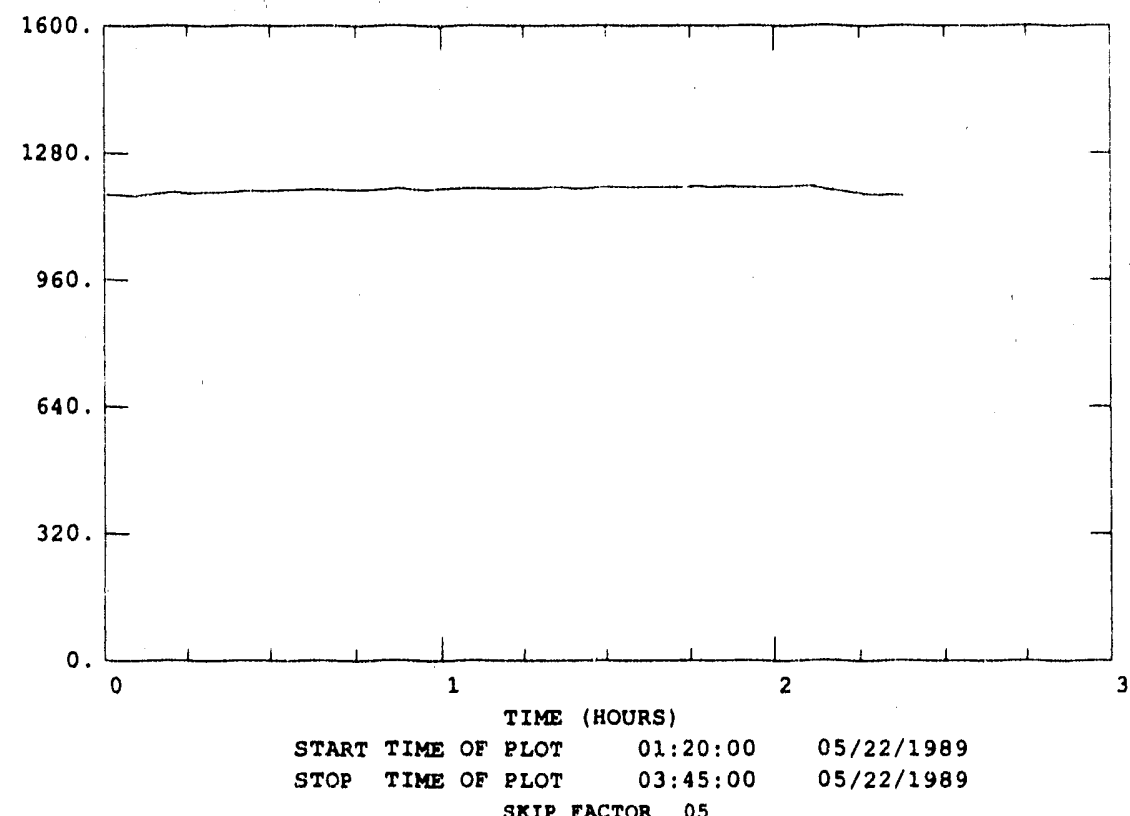

rigure 41. Disc rilter Outlet Temperature During Disc rilter Test Dr4 


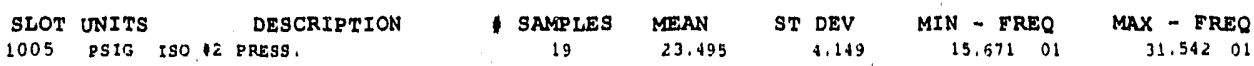

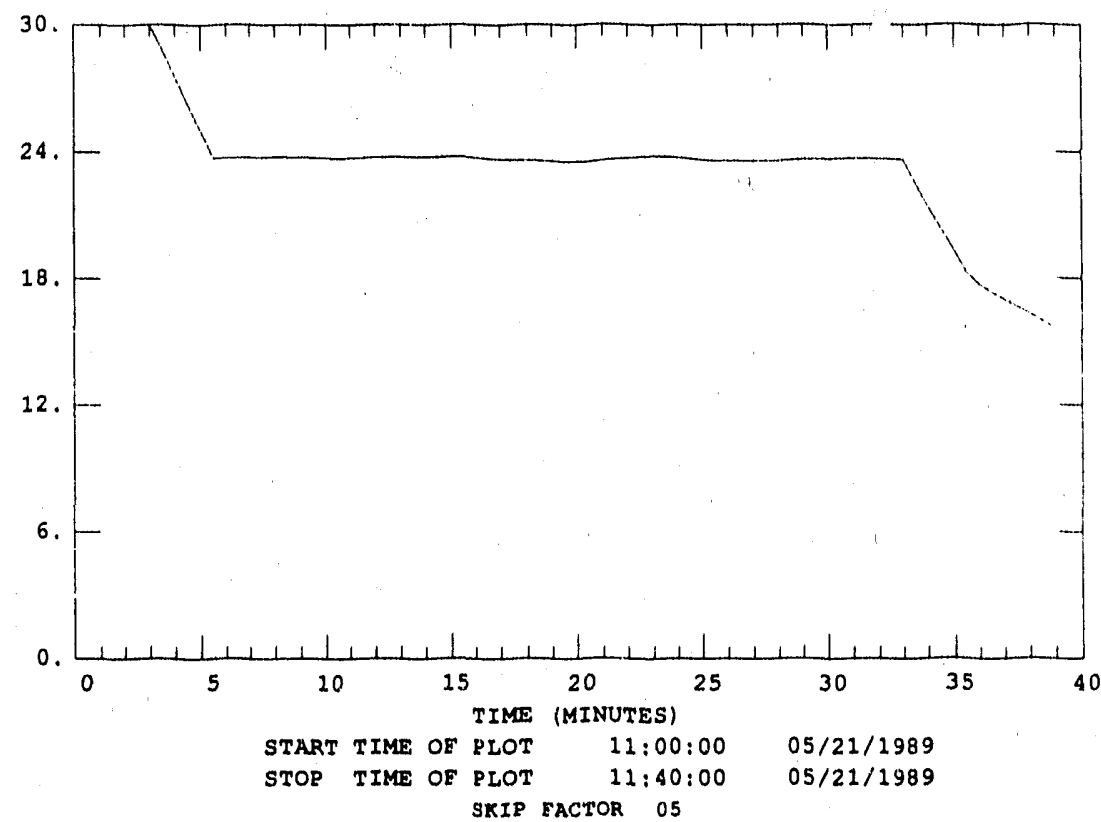

rigure 42. Disc rilter Vessel Pressure During Disc rilter Test DF4

\begin{tabular}{|c|c|c|c|c|c|c|c|c|c|c|}
\hline SLOT & UNITS & & DES & CRIPTION & - SAMPLES & MEAN & ST DEV & $M I N-E$ & & MAX - EREC \\
\hline 394 & ${ }^{*} \mathrm{H} 2 \mathrm{O}$ & PATCH & FILTEP & DP & 23 & 12.617 & 5.017 & 2,799 & 01 & 17.878 \\
\hline 310 & SCFY & PATCH & FILTEP & HI FLOW & 23 & 47.052 & 20.614 & $10.22 \mathrm{~B}$ & 01 & 6.5 .071 \\
\hline 311 & FT:'M & EATCH & FILTER & FACE VLLOCITY & 23 & 3.777 & 3.764 & 2.455 & 01 & 12.313 \\
\hline
\end{tabular}

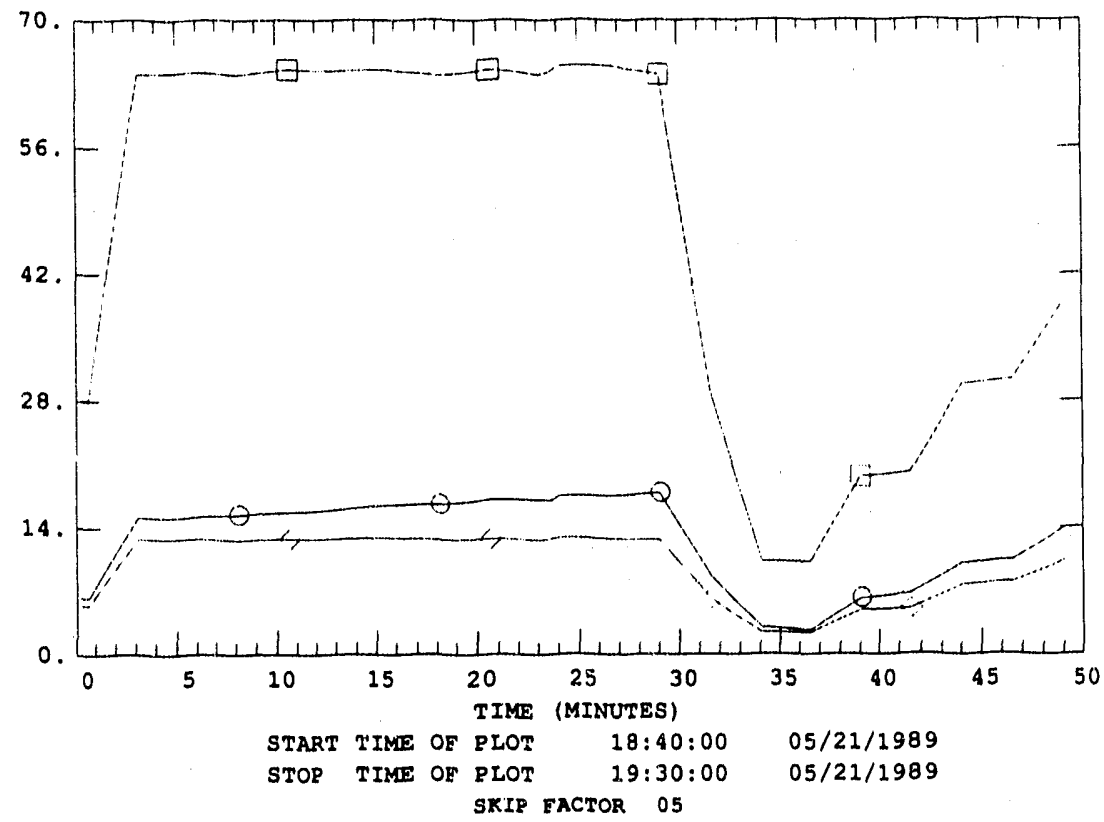

Figure 43. Pressure Drop, Ilow Rate, and Face Velocity During Disc rilter Test Dr5 
SLOT UNITS DESCRIPTION SAMPLES MEAN ST DEV MIN - EREQ MAX - FREQ

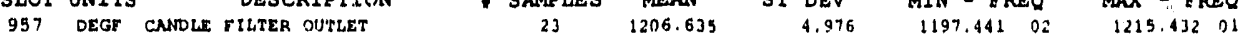

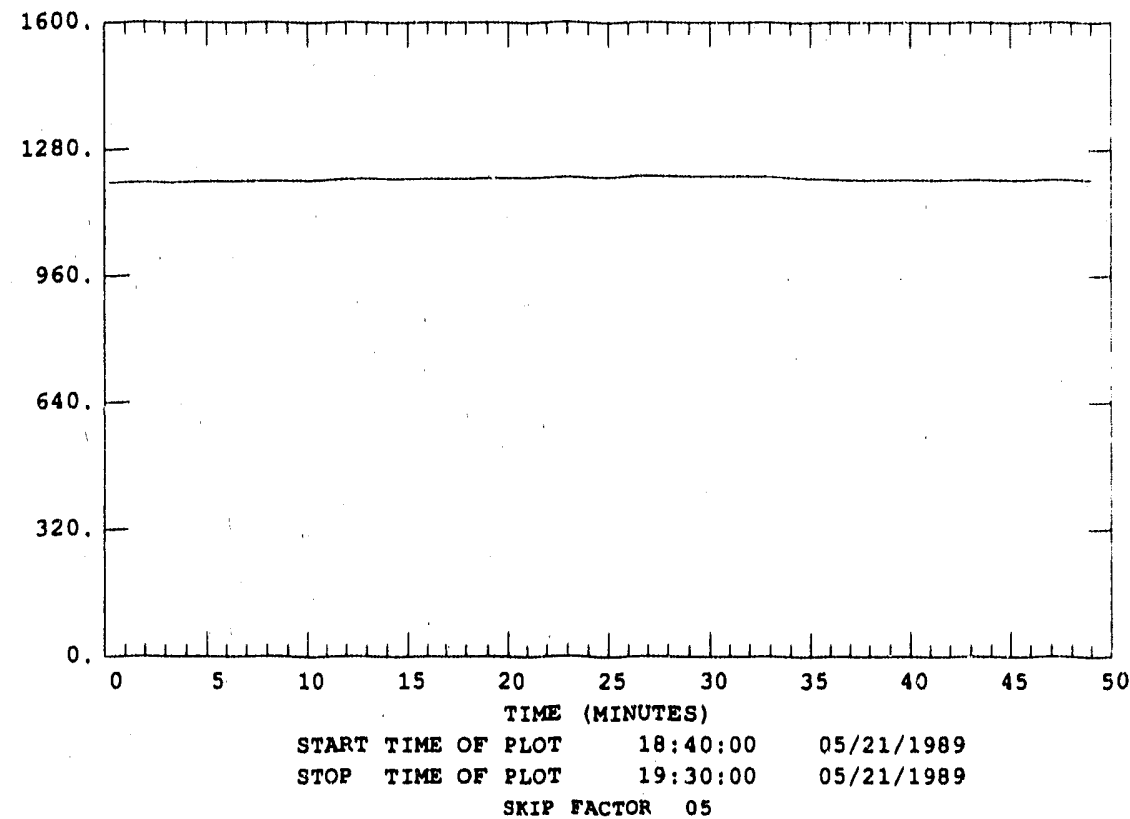

Figure 44. Disc rilter Outlet Temperature During Disc rilter Test Dr5

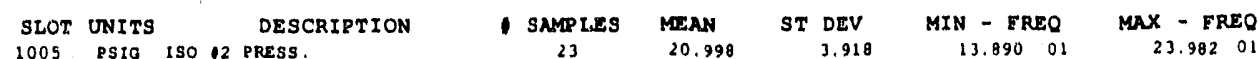

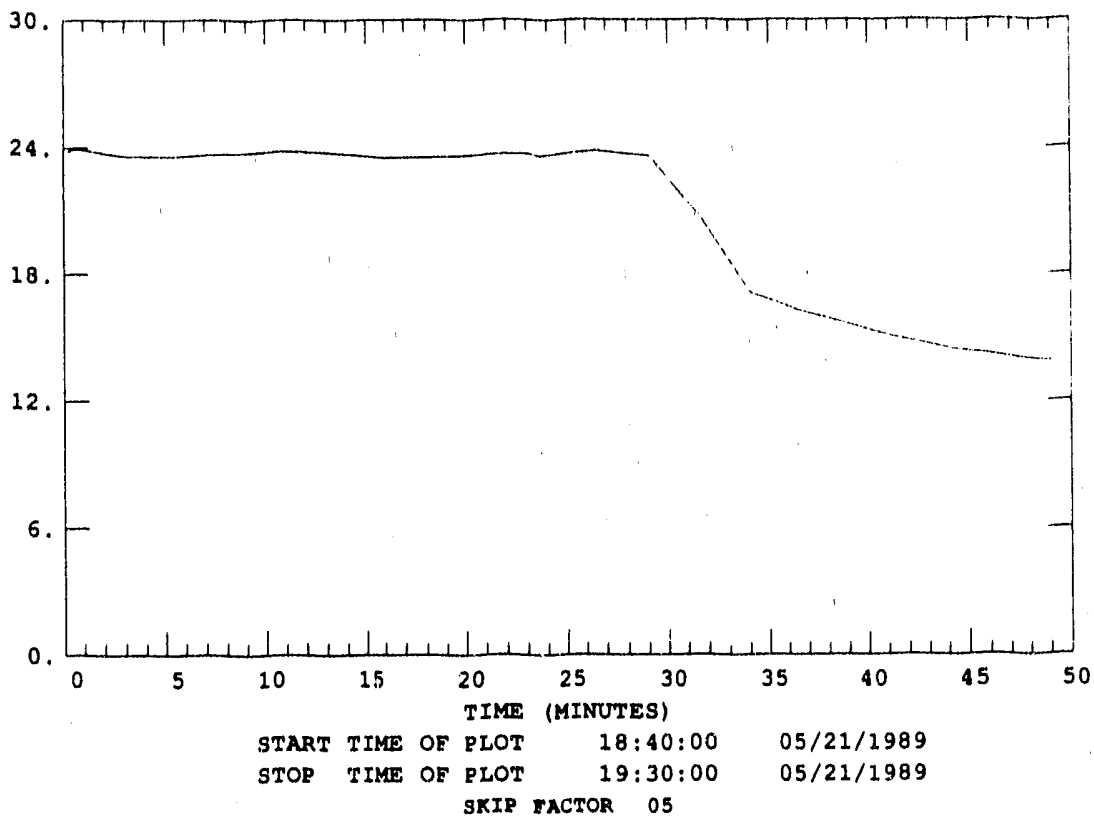

rigure 45. Disc rilter Vessel Pressure During Disc rilter Test Dr5 


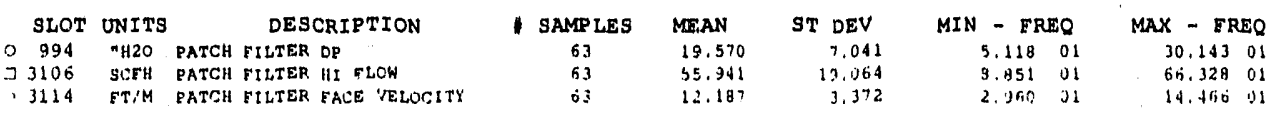

, 3114 FTM PATCH FILTER FACE

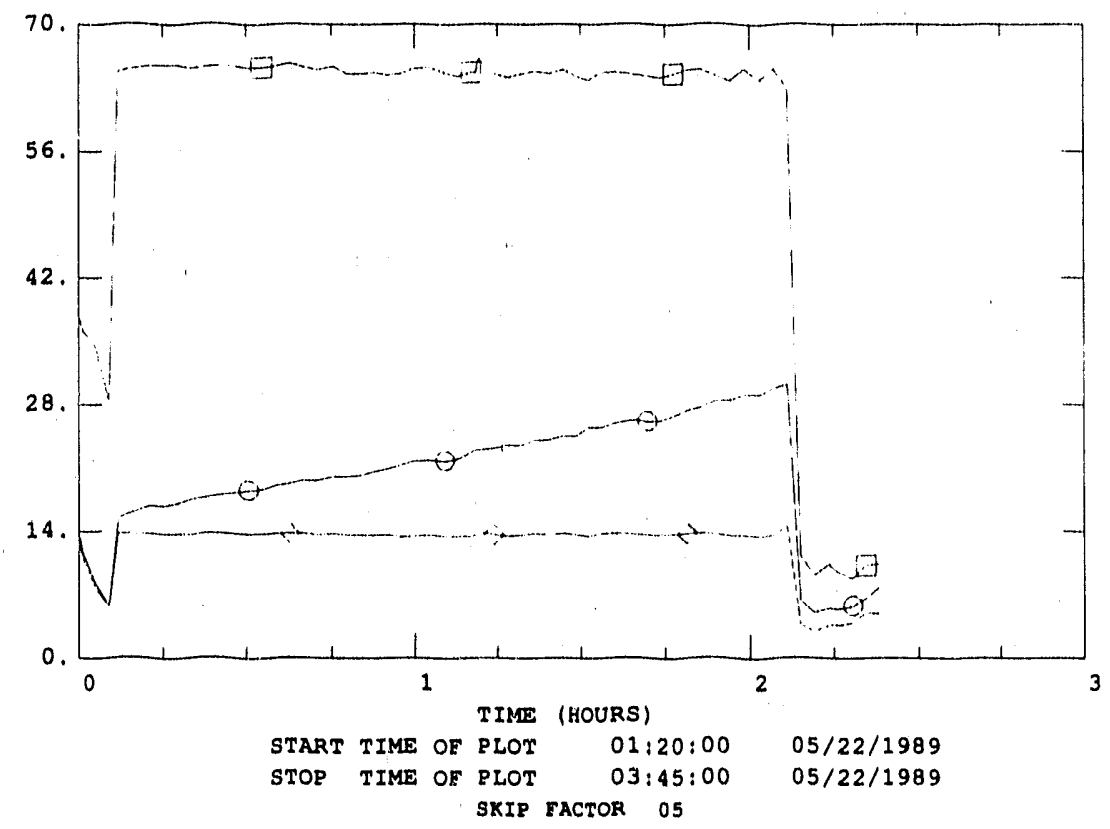

Tigure 46. Pressure Drop, Flow Rate, and Tace Velocity During Disc rilter Test Dr6

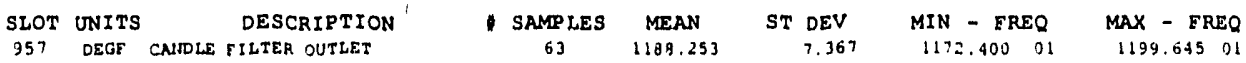

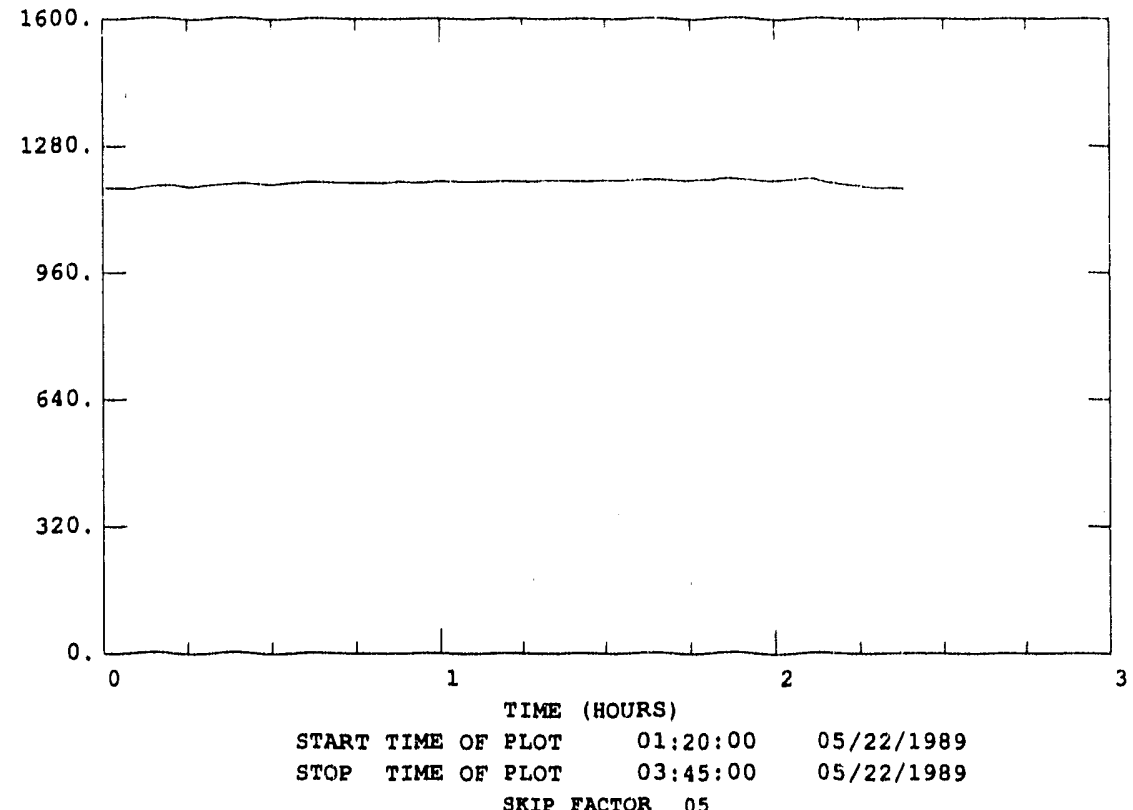

Rigure 47. Disc rilter Outlet Temperature During Disc Filter Test Dr6 


SLOT UNITS
LOOS PSTG 19012 PRESS.

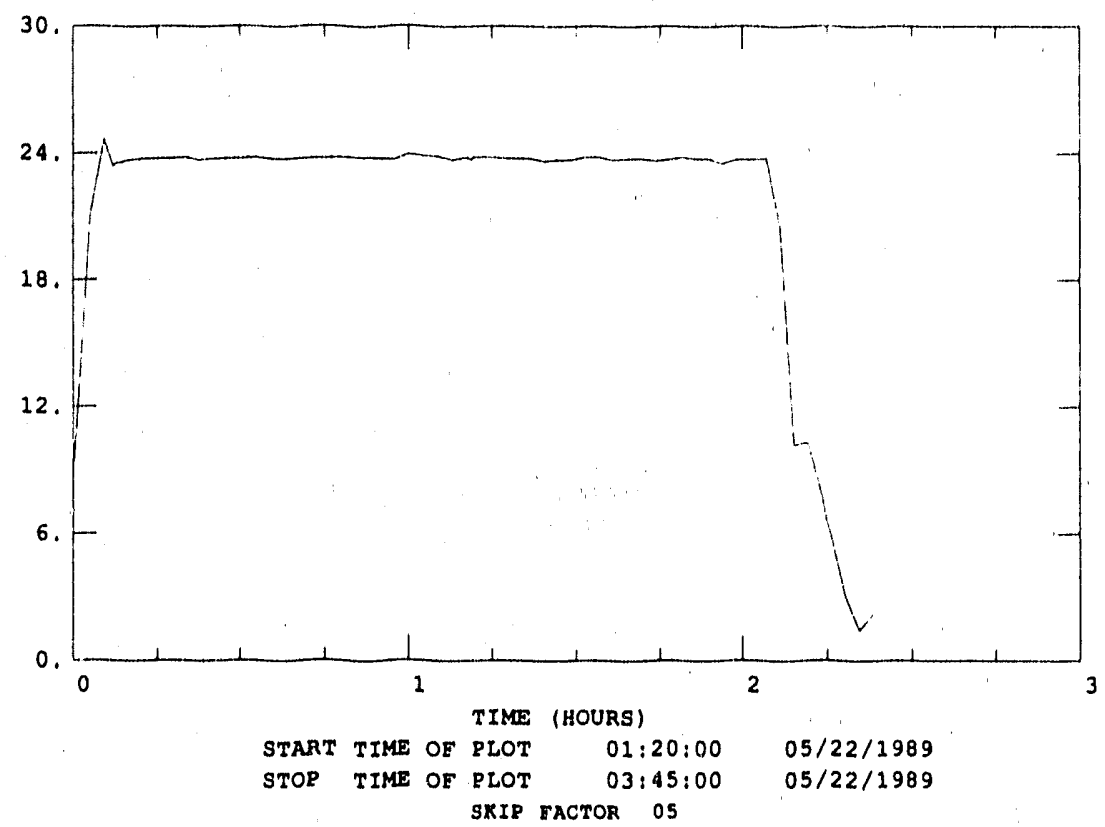

rigure 48. Disc rister Vessel Pressure During Disc rilter rest Dr6

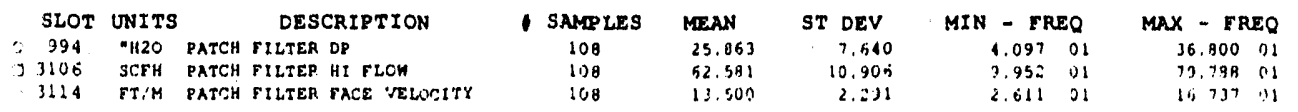

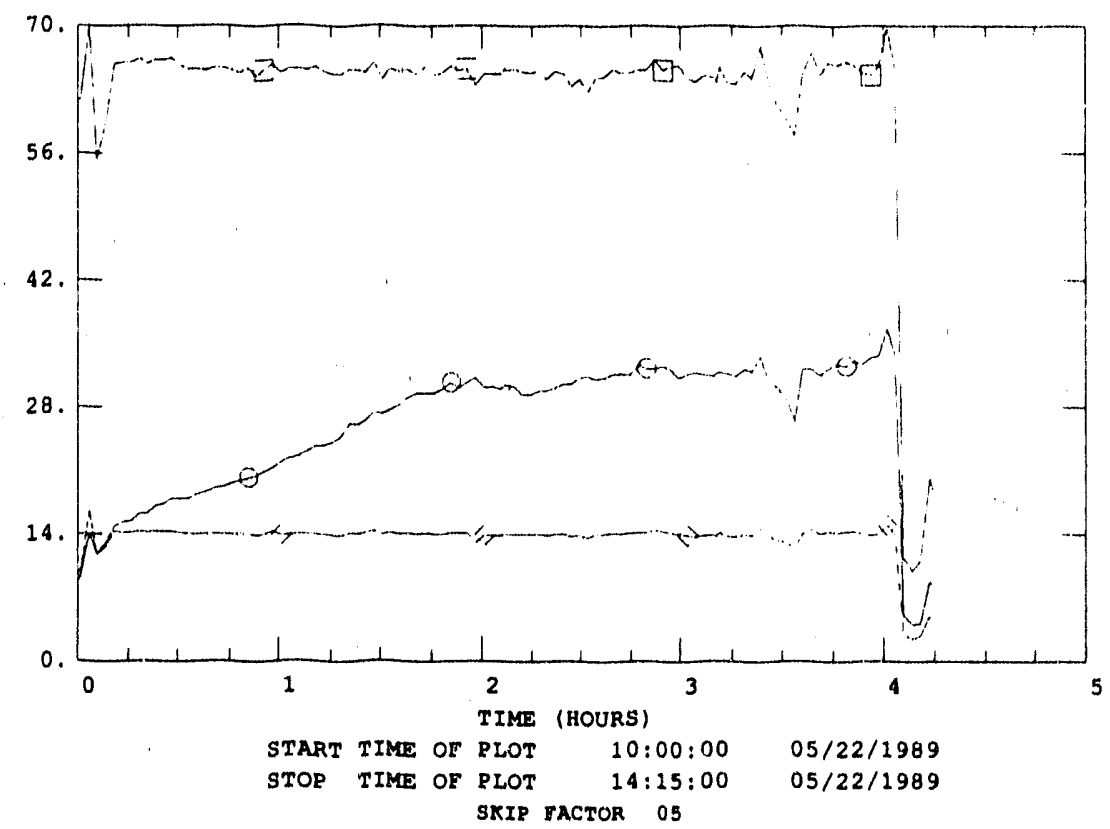

rigure 49. Rressure Drop, rlow Rate, and race Velocity During Disc rilter Test Dr7 


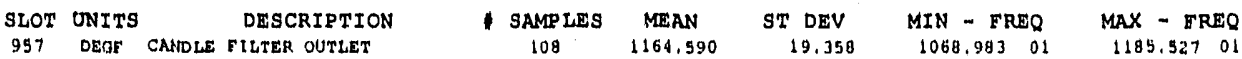

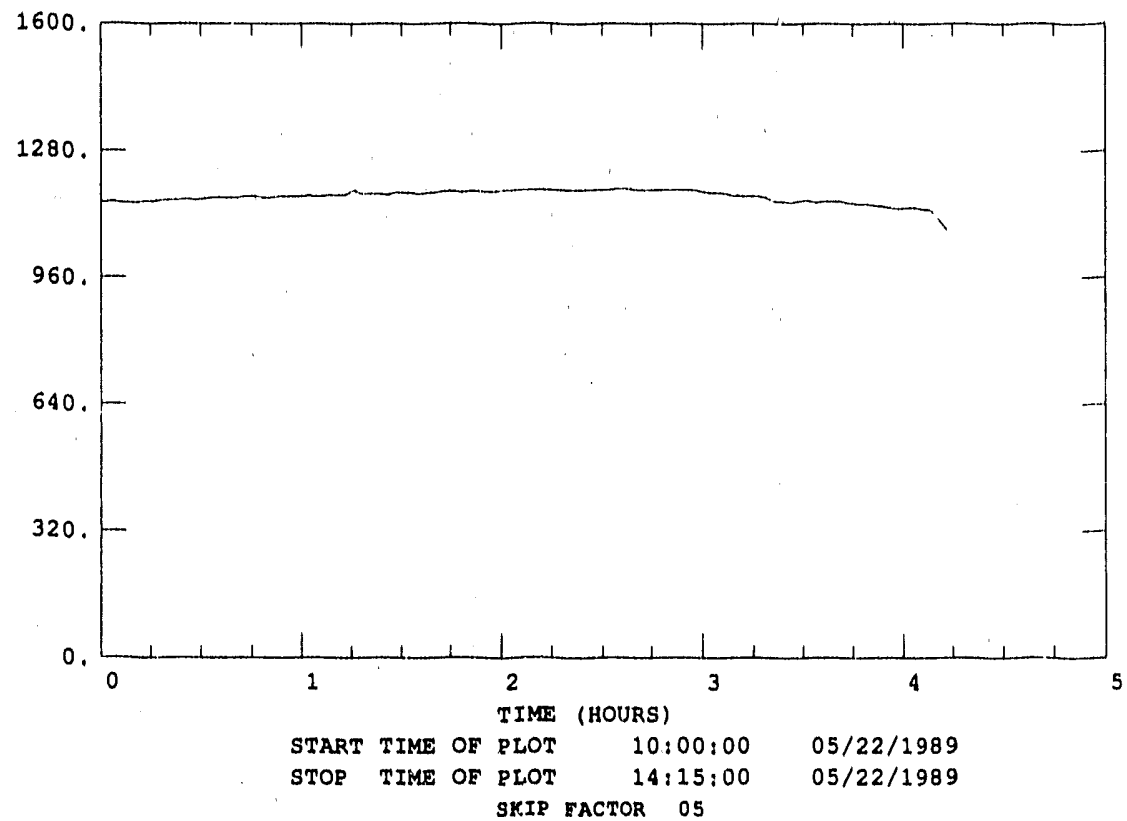

rigure 50. Disc Filter Outlet Temperature During Disc Eilter Test Dr7

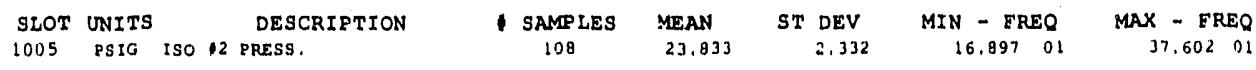

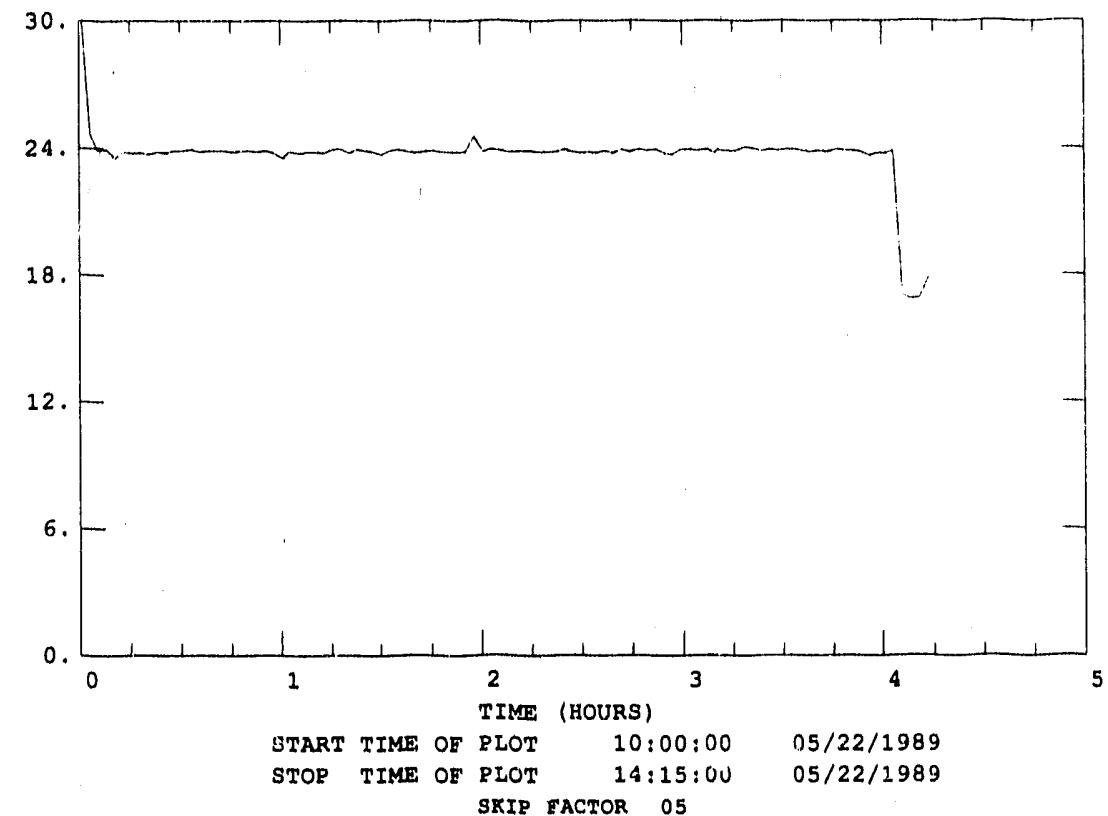

Vigure 51. Disc Vilter Vessel Pressure During Disc Filter Test DF7 

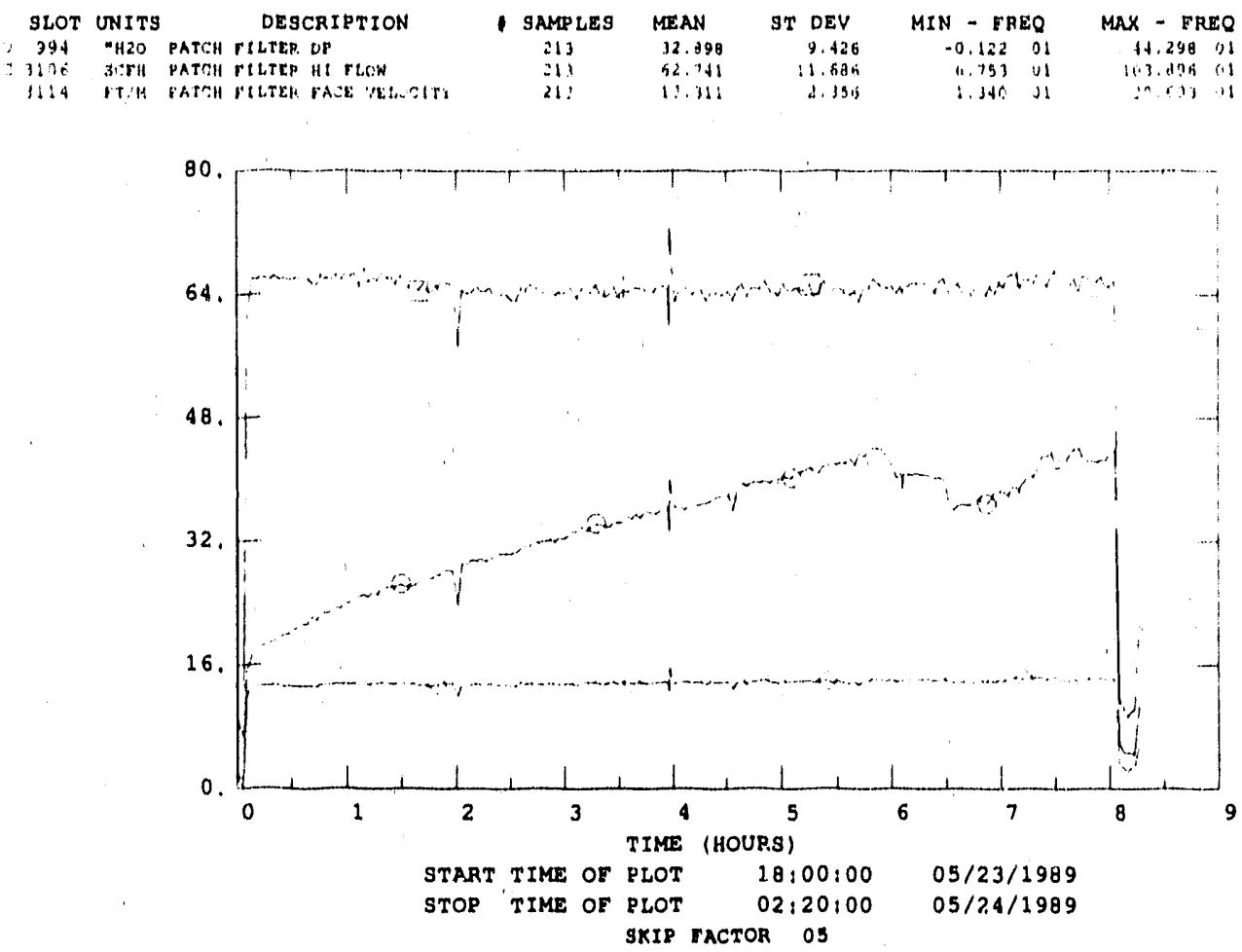

Tigure 52. Pressure Drop, Tlow Rate, and Tace Volocity During Disc riltex Test Dr8

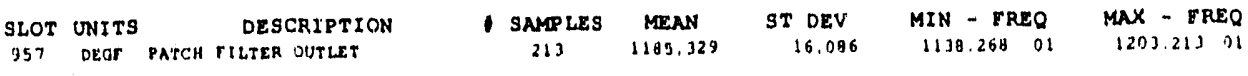

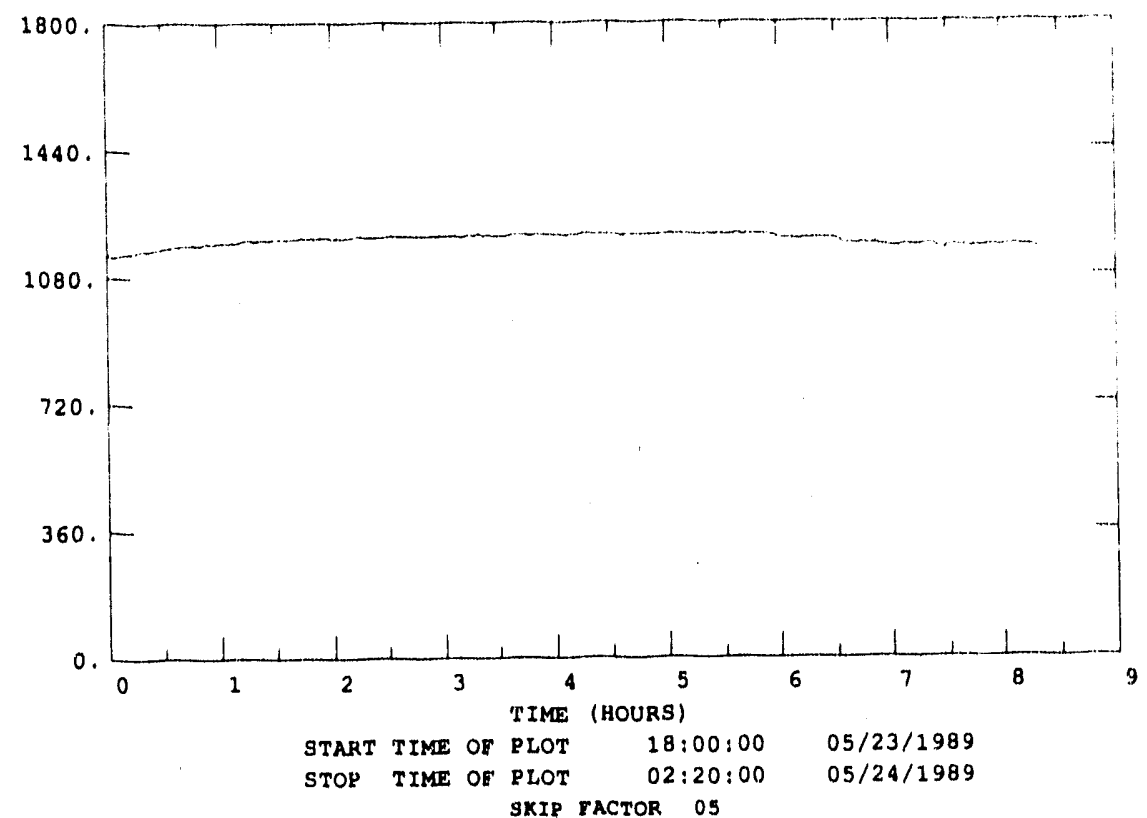

rigure 53. Disc rilter Outlet Temperature During Disc rilter Test Dr8 
SLOT UNTTS DESCRIPTION I SAMPLES MEAN ST DEV MIN - FREO MAX - TREO

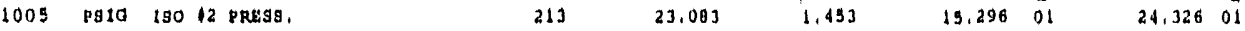

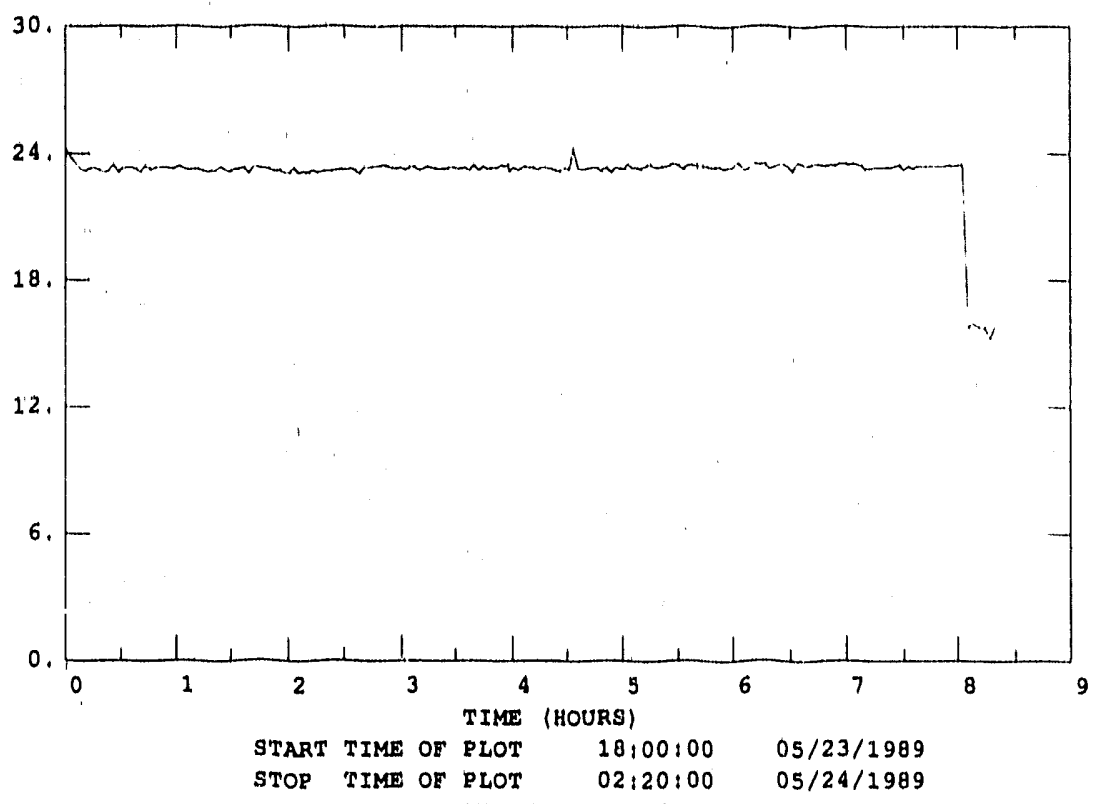

rigure 54. Disc rilter Vessel Pressure During Disc rilter Tast Dr8

\begin{tabular}{|c|c|c|c|c|c|c|c|c|c|c|}
\hline SLOT & UNITS & & DES & CRIPTION & - SAMPLES & MEAN & ST DEV & $M I N-E$ & EO & MAX - EREQ \\
\hline 994 & ${ } \mathrm{H}_{2} \mathrm{O}$ & PATCH & rILTEF & DP & $105^{\circ}$ & 21.759 & 5,780 & -0.501 & 02 & 30.98901 \\
\hline 310 & SCFH & PATCH & FILTEP & HI rLOW & LAS & 61.591 & 10.674 & 5,535 & D) 1 & 105.15101 \\
\hline 3114 & rtim & PATSH & FILTE & Face vetontTy & 195 & 11.300 & 2.172 & 1.387 & ji & $20.359 \quad 1$ \\
\hline
\end{tabular}

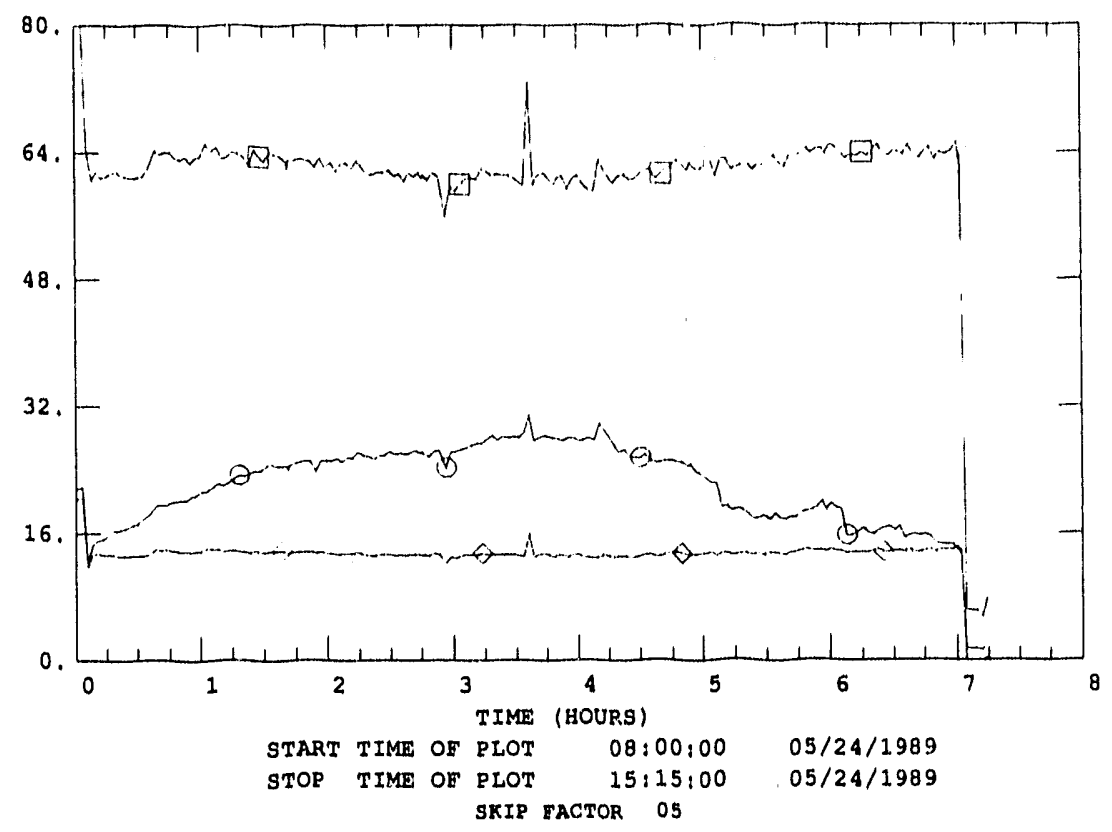

Figure 55. Pressure Drop, Flow Rate, and Face Velocity During Disc rilter Test DF9 


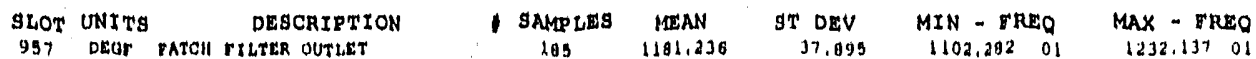

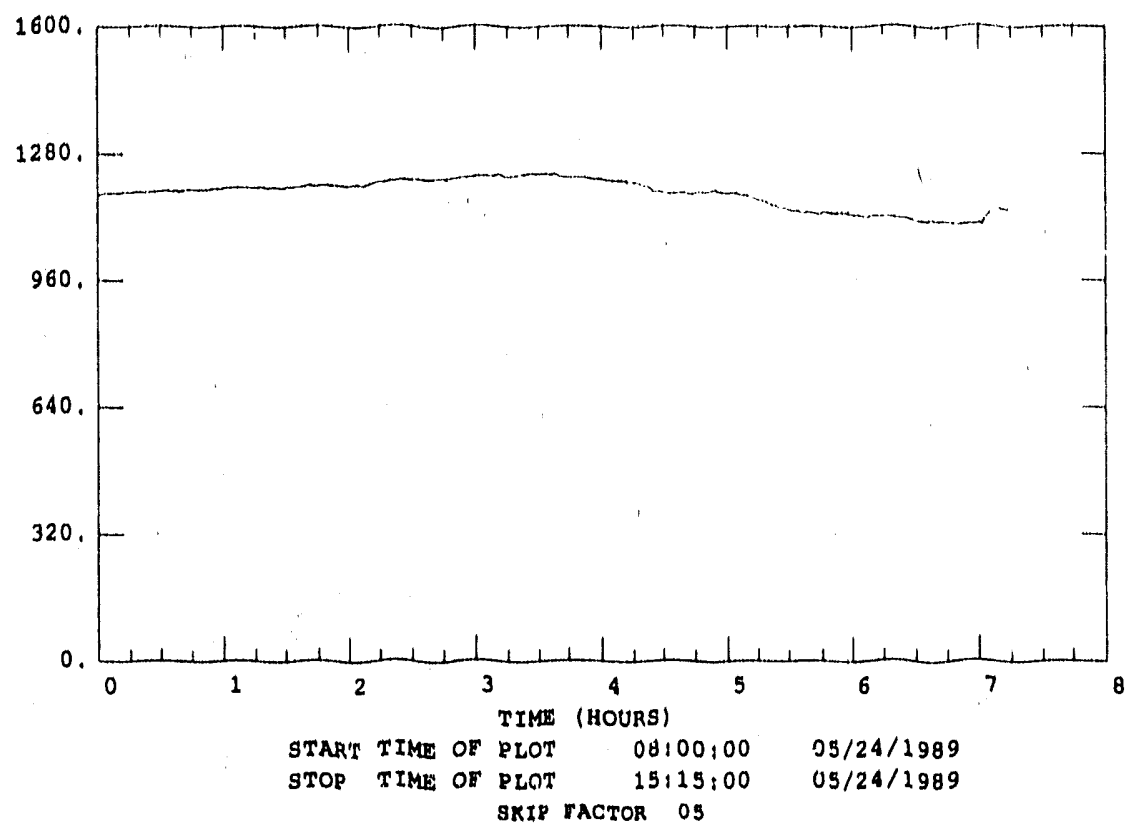

rigure 56. Disc rilter Outlet Temperature During Disc rilter Test Dr9 SLOT UNITS DESCRIPTION
lo09 PGIG 190.2 PRESS.

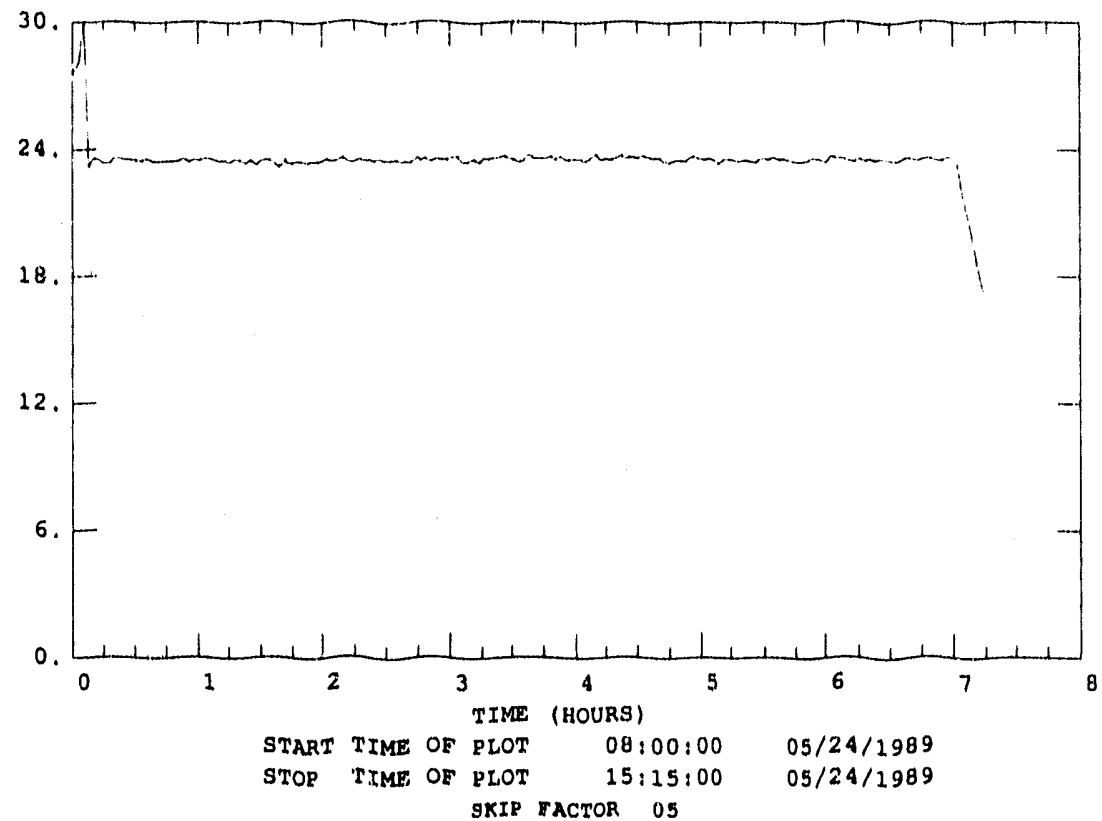

rigure 57. Disc rilter Vessel Pressure During Disc rilter Test Drg 


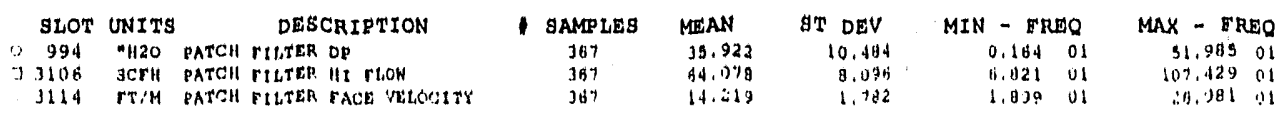

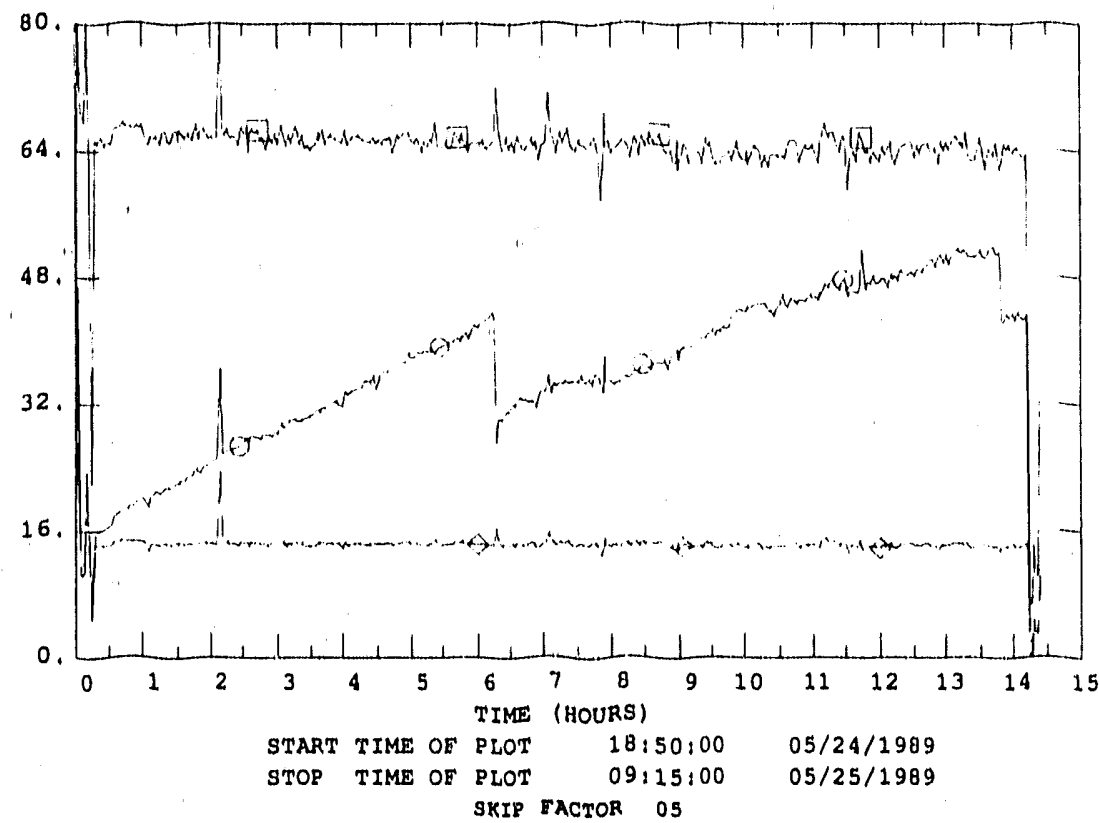

Figure 58. Pressure Drop, rlow Rate, and race Velocity During Disc Vilter Test Dr10

$\begin{array}{lcccccc}\text { SLOT UNITS } & \text { DESCRIPTION } & \text { SAMPLES } & \text { MEAN } & \text { ST DEV } & \text { MIN - FREO } & \text { MAK - FREO } \\ \text { 957 DEG PATCH FILTER OUTLET } & 367 & 1168.158 & 14.721 & 1094.30101 & 1193.90901\end{array}$

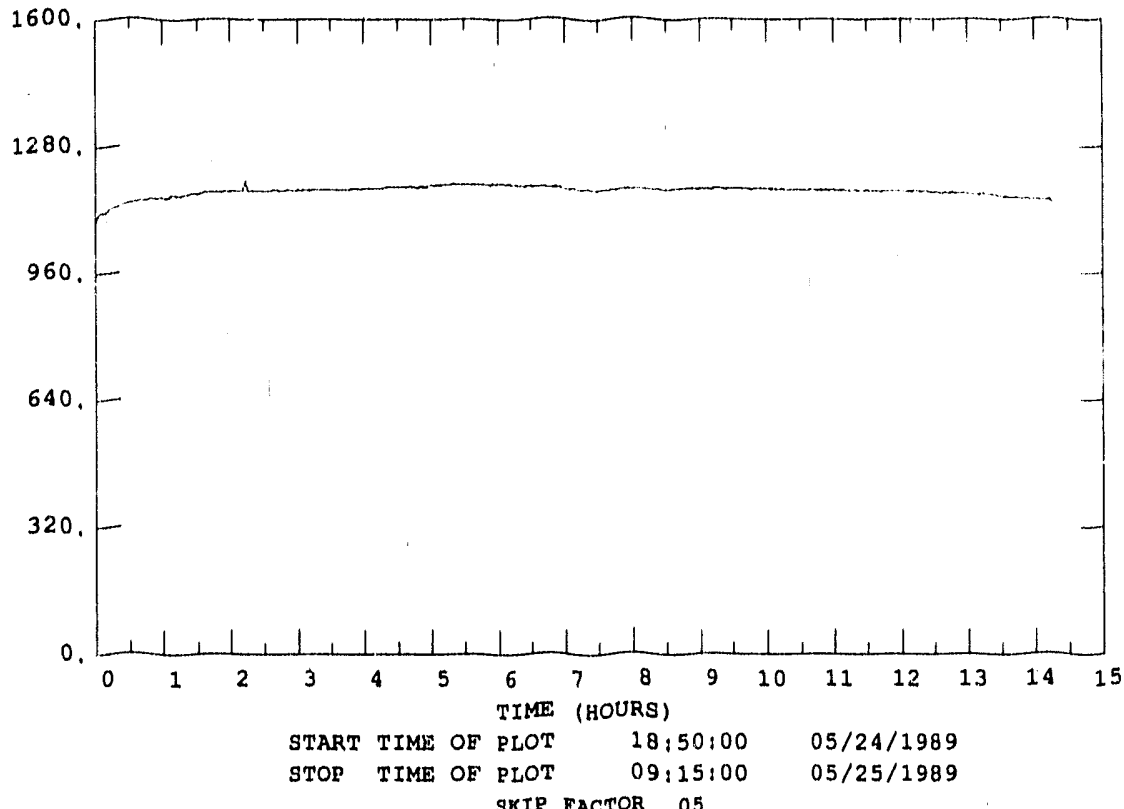

Figure 59. DisC Filtex Outlet Temperature During Disc Filtex Test Dr10 


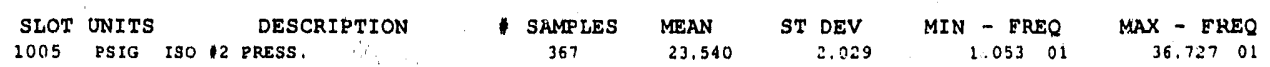

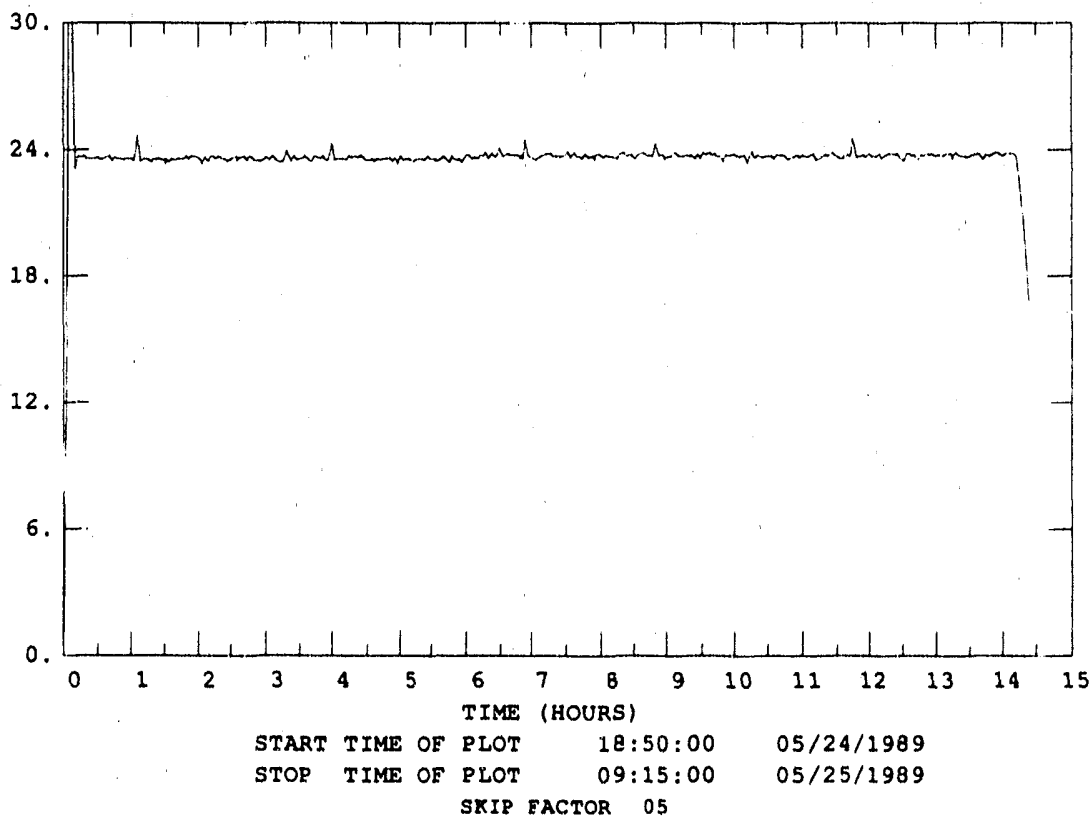

Figure 60. Disc Tilter Vessel Pressurs During Disc rilter Test DF10

\begin{tabular}{|c|c|c|c|c|c|c|c|c|c|}
\hline SLOT & UNITS & & DESCRIPTION & - SAMPLES & MEAN & ST DEV & $M I N-F$ & $\mathbf{E Q}$ & MAX - FREQ \\
\hline 99 & "H2O & PATCH & FILTER DP & 336 & 165 & 27.796 & 4,373 & 01 & 110.74401 \\
\hline & SCEH & PATCH & FILTEP HI FLCH & 336 & 65.382 & 4.689 & 12.157 & D) 2 & A5.277 01 \\
\hline 32 & ET;M & EATCH & FILTEE FACE VELOCITY & 336 & 11.005 & 2.310 & 2.429 & ji & 21.231 \\
\hline
\end{tabular}

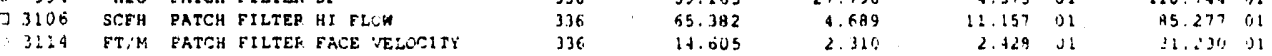

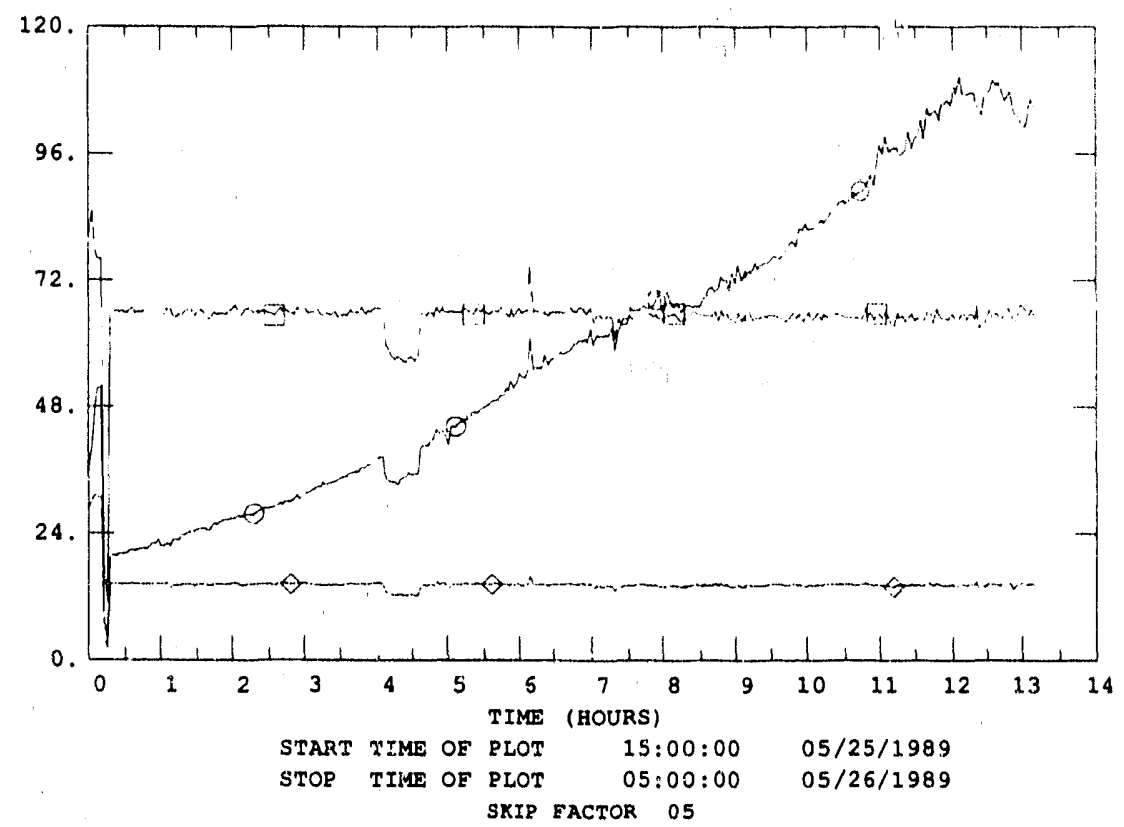

Figure 61. Pressure Drop, Ilow Rate, and Face Velocity During Disc Filter Test Dr11 


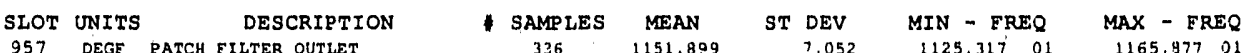

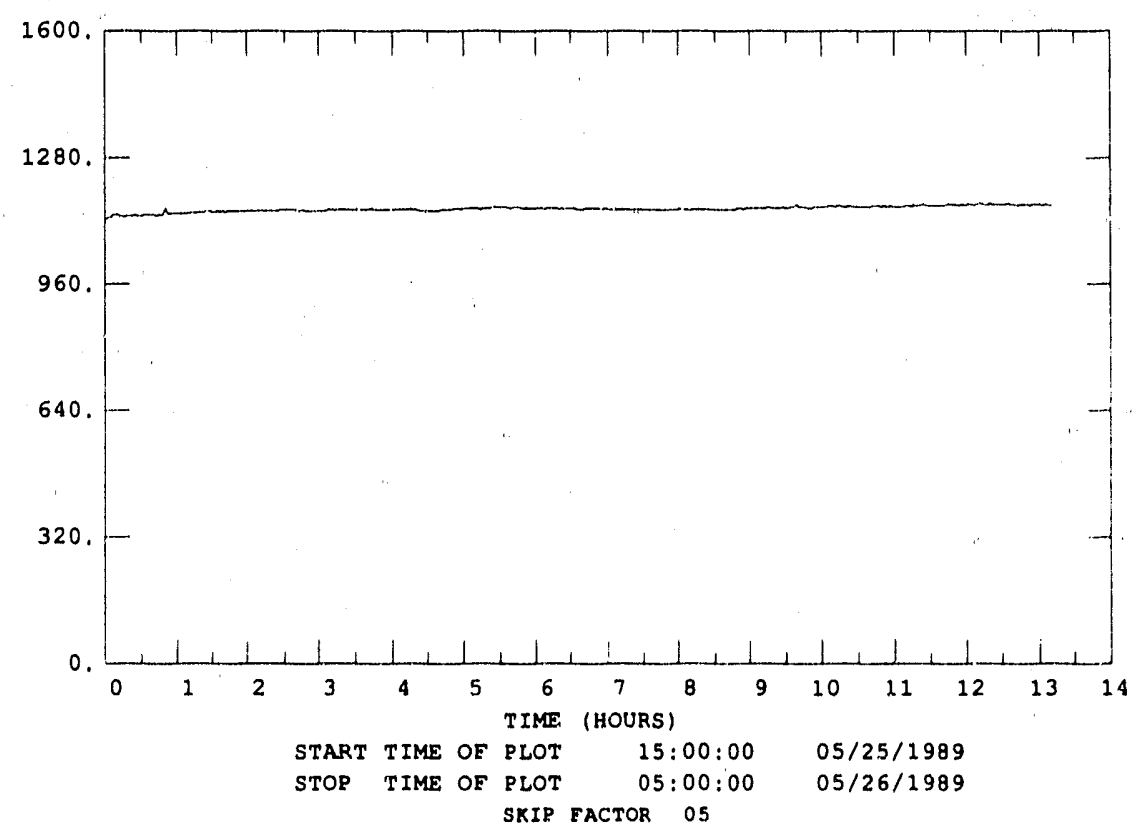

Figure 62. Disc rilter Outlet Temperature During Disc Filter Test Dr11

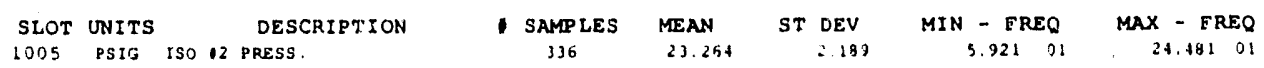

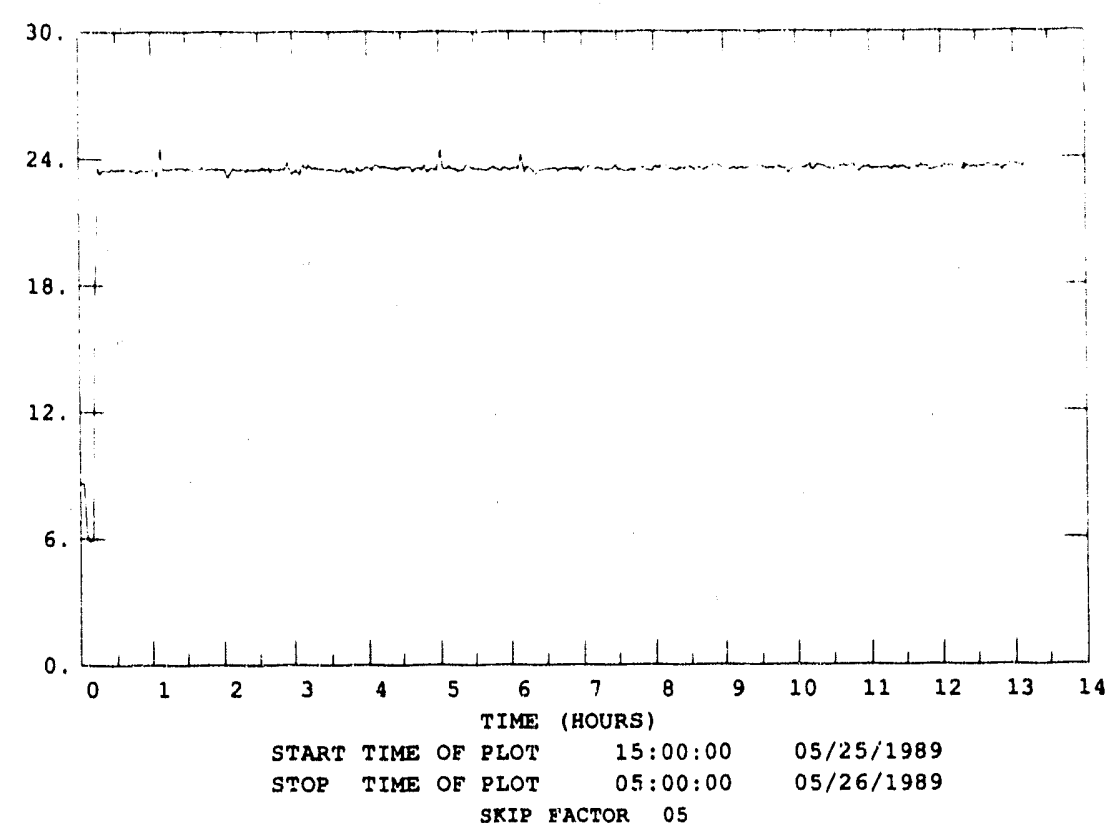

Figure 63. Disc Filter Pressure During Disc rilter Test DF11 
Presented in Table 11 is a iist of process variables recorded when clean heated nitrogen was passed through the disc filter with a formed dust cake. The measured data were pressure drop, vessel pressure, temperacure, and flow rate. The filter face velocity and $k_{2}$ values were calculated from these data. Boih pressure drop and $\mathrm{K}_{2}$ values are plotted against face velocity and are presented for each test. Data for DisC Filter Test DF10 was lost in a computer failure. 
Table 11. Rrocess Parameters then Hot Nitrogen Was

Passed Through the Formed Dust Cake

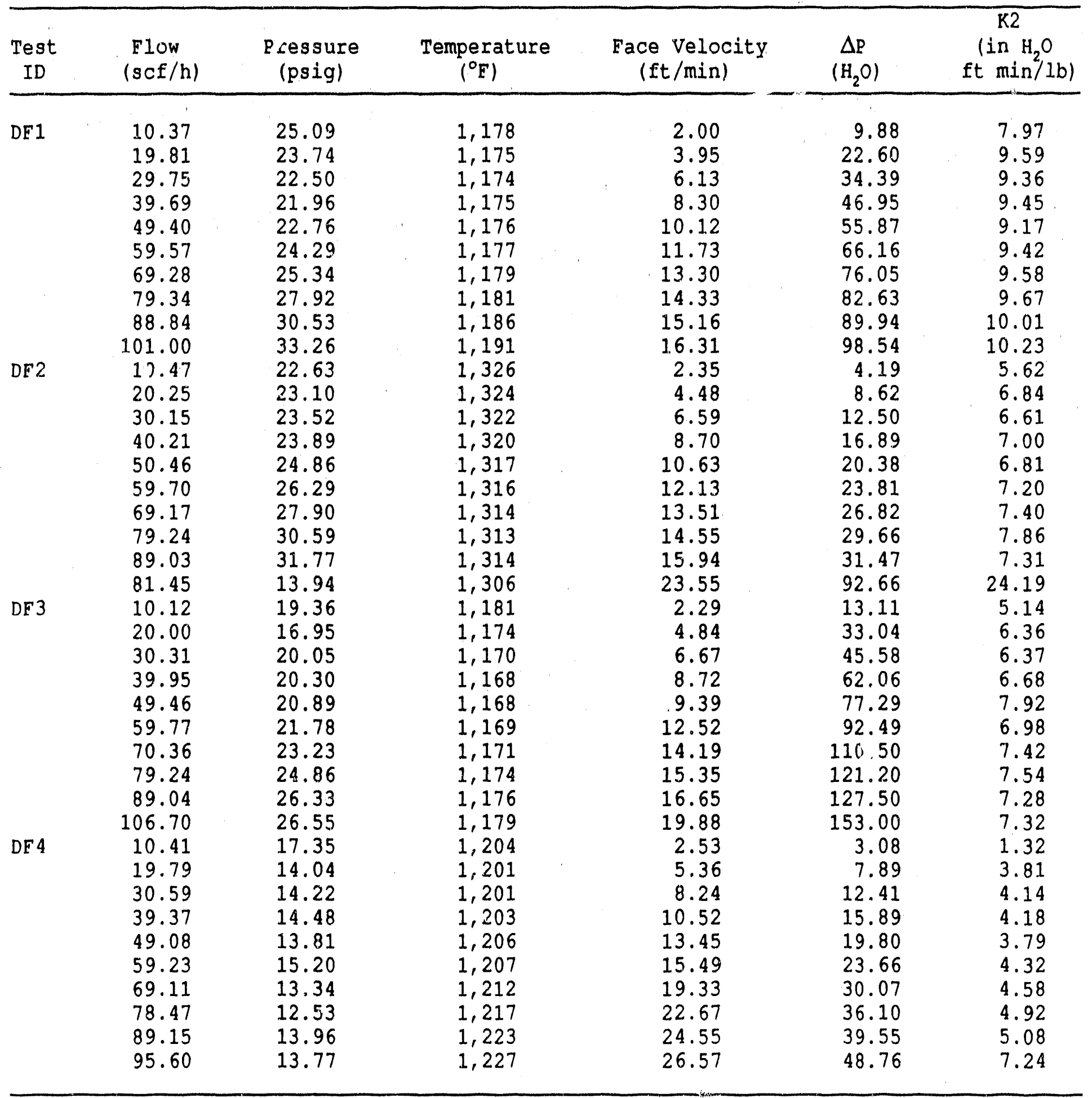


Table 11. Process Parameters When Hot Nitrogen Was

Passed Through the Formed Dust Cake

(Continued)

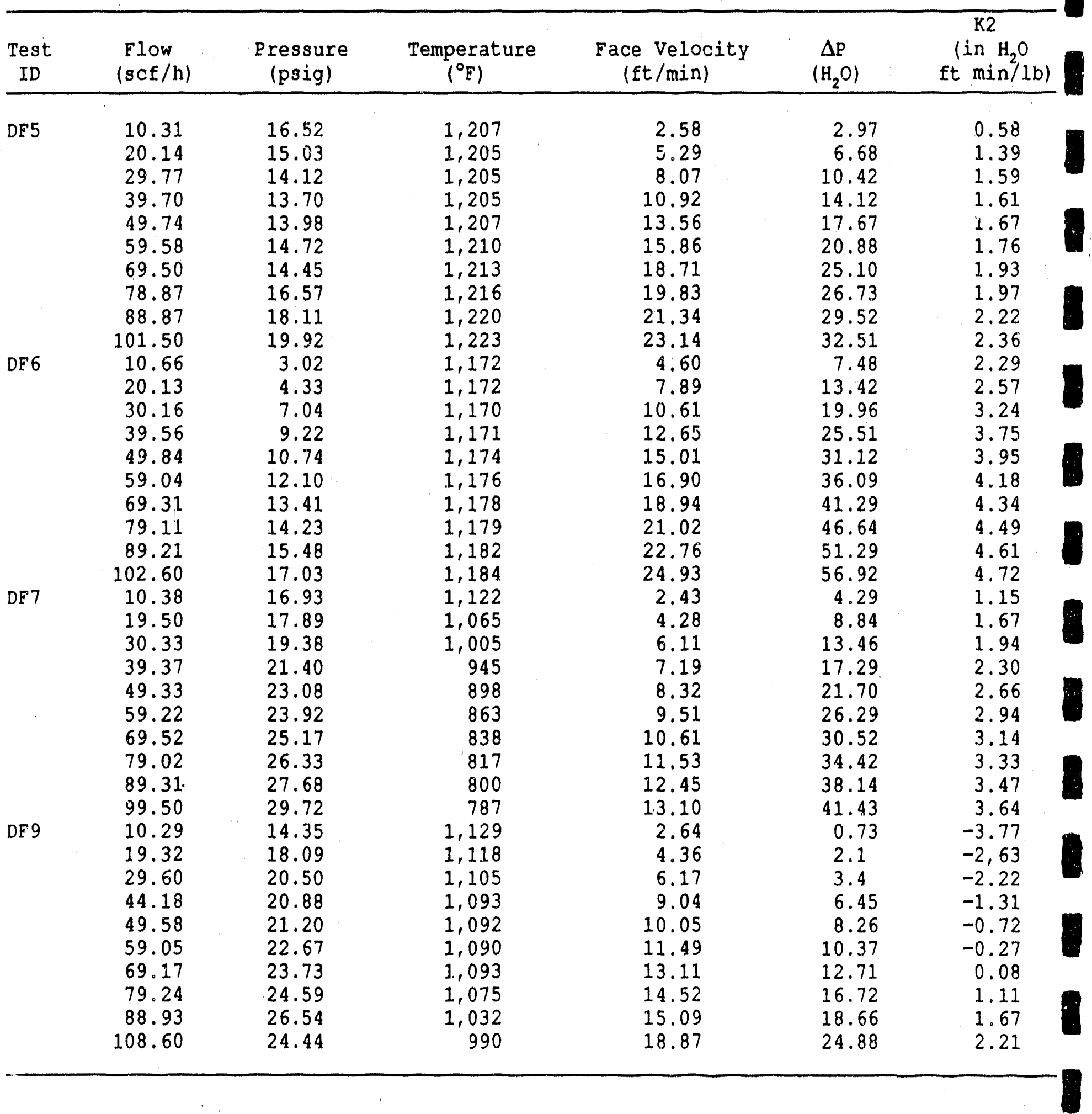


Table 11. Process Rarameters When Hot Nitrogen Was

Rassed Through the rormed Dust Cake

(Continued)

\begin{tabular}{|c|c|c|c|c|c|c|}
\hline $\begin{array}{l}\text { Test } \\
\text { ID }\end{array}$ & $\begin{array}{l}\text { Flow } \\
(\mathrm{scf} / \mathrm{h})\end{array}$ & $\begin{array}{l}\text { Pressure } \\
\text { (psig) }\end{array}$ & $\begin{array}{c}\text { Temperature } \\
\end{array}$ & $\begin{array}{c}\text { Face Velocity } \\
(\mathrm{ft} / \mathrm{min})\end{array}$ & $\begin{array}{c}\Delta \mathrm{P} \\
\left(\mathrm{H}_{2} \mathrm{O}\right)\end{array}$ & $\begin{array}{c}\mathrm{k} 2 \\
\left(\mathrm{in} \mathrm{H}_{2} \mathrm{O}\right. \\
\text { ft } \min / \mathrm{lb})\end{array}$ \\
\hline DF 8 & $\begin{array}{r}10.03 \\
19.93 \\
29.40 \\
39.41 \\
49.64 \\
59.20 \\
68.65 \\
79.36 \\
89.04 \\
101.50 \\
15.99 \\
20.04 \\
29.92 \\
39.37 \\
48.86 \\
58.12 \\
67.36 \\
77.01 \\
76.43 \\
77.12\end{array}$ & $\begin{array}{r}15.77 \\
15.69 \\
17.27 \\
18.91 \\
19.74 \\
20.68 \\
21.73 \\
23.17 \\
25.19 \\
25.84 \\
3.00 \\
10.05 \\
11.02 \\
11.16 \\
10.44 \\
9.25 \\
9.22 \\
9.84 \\
10.71 \\
11.83\end{array}$ & $\begin{array}{l}1,164 \\
1,160 \\
1,151 \\
1,150 \\
1,149 \\
1,152 \\
1,154 \\
1,149 \\
1,149 \\
1,161 \\
1,127 \\
1,121 \\
1,120 \\
1,123 \\
1,126 \\
1,132 \\
1,137 \\
1,142 \\
1,148 \\
1,151\end{array}$ & $\begin{array}{r}2.51 \\
4.98 \\
6.95 \\
8.85 \\
10.88 \\
12.63 \\
14.26 \\
15.81 \\
16.84 \\
18.58 \\
6.73 \\
6.00 \\
8.62 \\
11.30 \\
14.46 \\
1.8 .12 \\
21.09 \\
23.58 \\
22.68 \\
21.96\end{array}$ & $\begin{array}{r}4.55 \\
11.07 \\
17.23 \\
24.46 \\
32.21 \\
40.21 \\
47.11 \\
52.00 \\
57.51 \\
64.05 \\
13.36 \\
33.13 \\
59.92 \\
83.92 \\
115.70 \\
142.70 \\
168.10 \\
192.00 \\
214.00 \\
230.00\end{array}$ & $\begin{array}{r}2.17 \\
3.72 \\
4.70 \\
5.77 \\
6.51 \\
7.33 \\
7.79 \\
7.75 \\
8.22 \\
8.32 \\
1.39 \\
6.53 \\
8.64 \\
9.34 \\
10.19 \\
10.00 \\
10.14 \\
10.39 \\
12.30 \\
13.84\end{array}$ \\
\hline
\end{tabular}




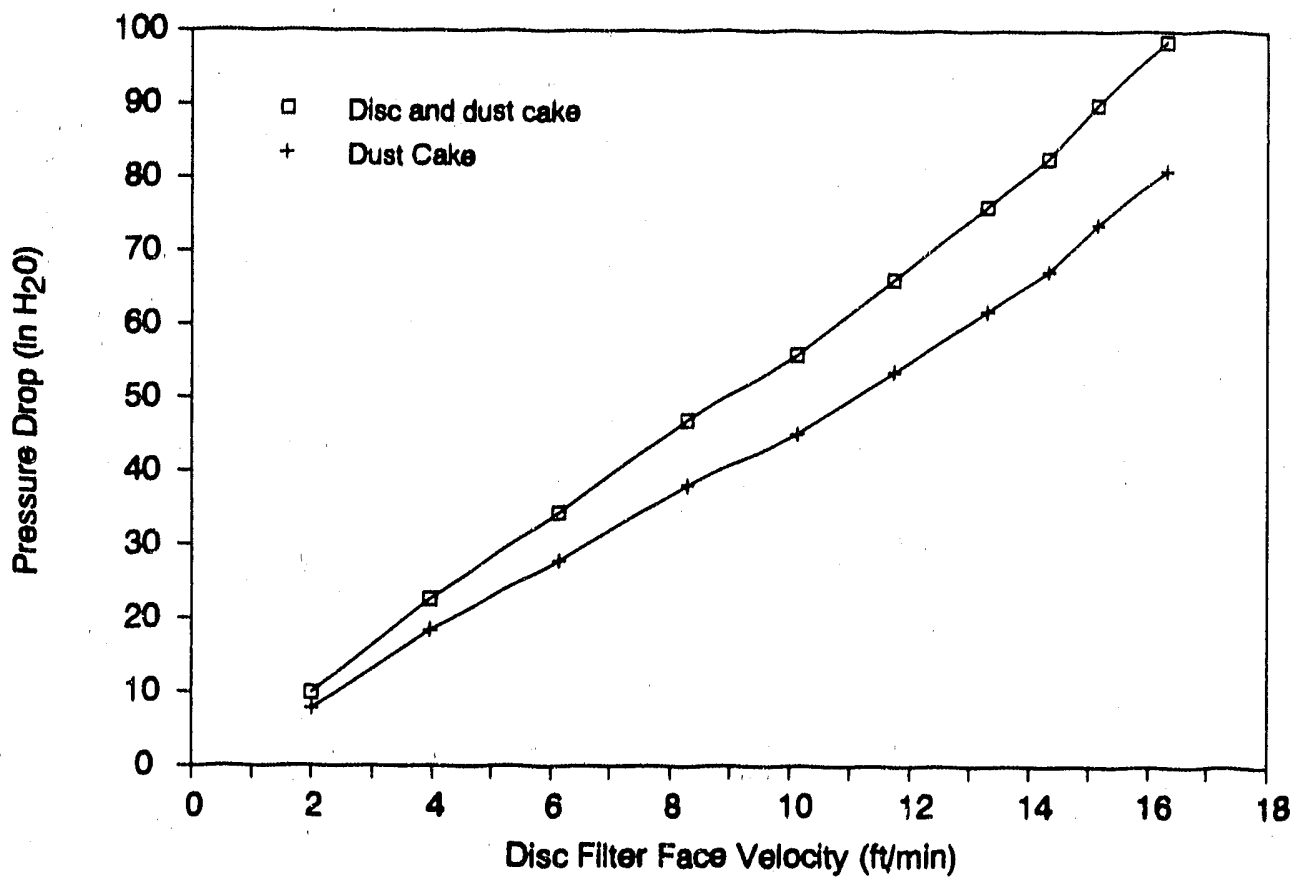

M91000858

Tigure 64. Effect of Face Velocity on Pressure Drop Through Disc rilter and Dust Cake for Disc rilter Test Dr1

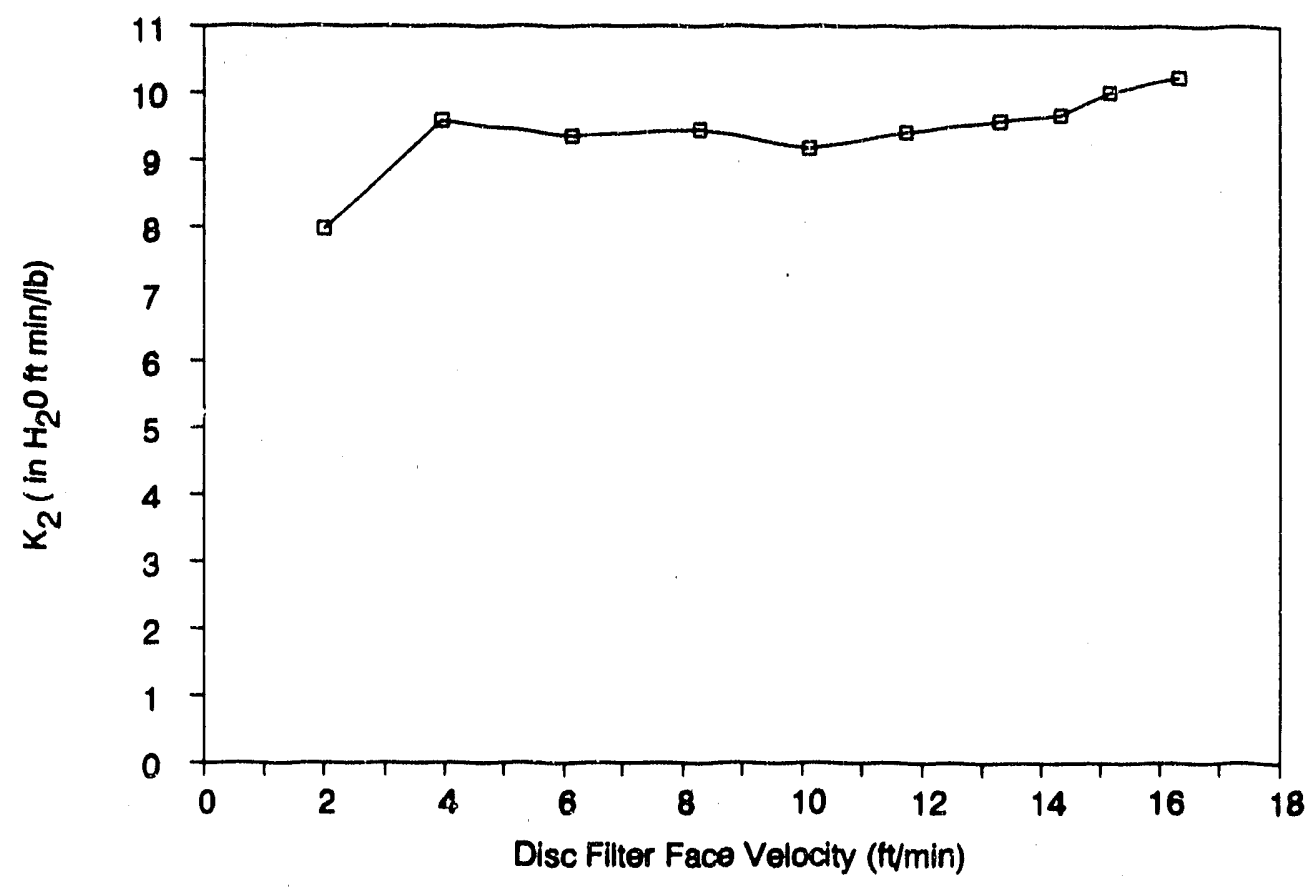

M91000859

rigure 65. Effect of race Velocity on $\mathbb{K}_{2}$ for Disc rilter Test Dr1 


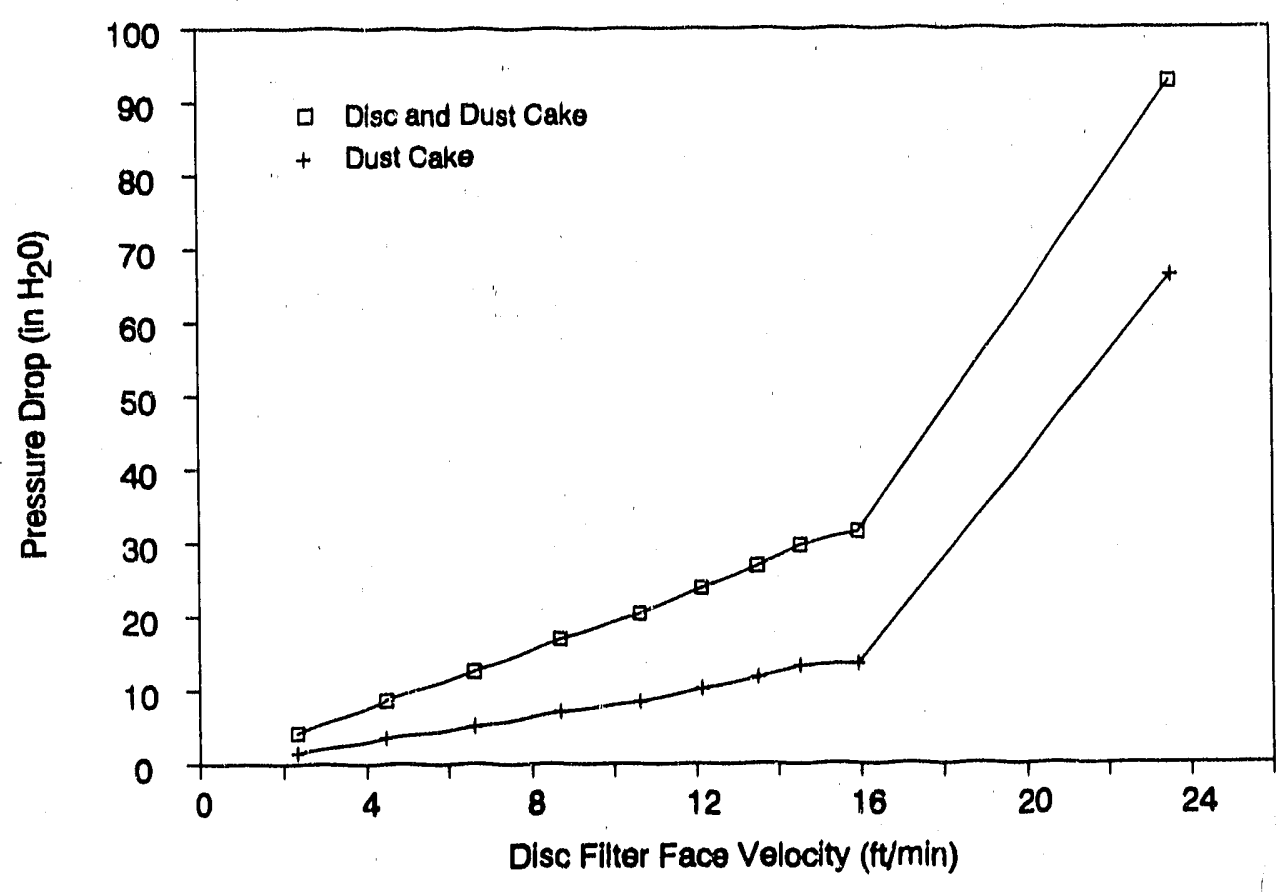

Figure 66. Effect of Tace Velocity on Pressure Drop Through Disc Filter and Dust Cake for Disc rilter Test DF2

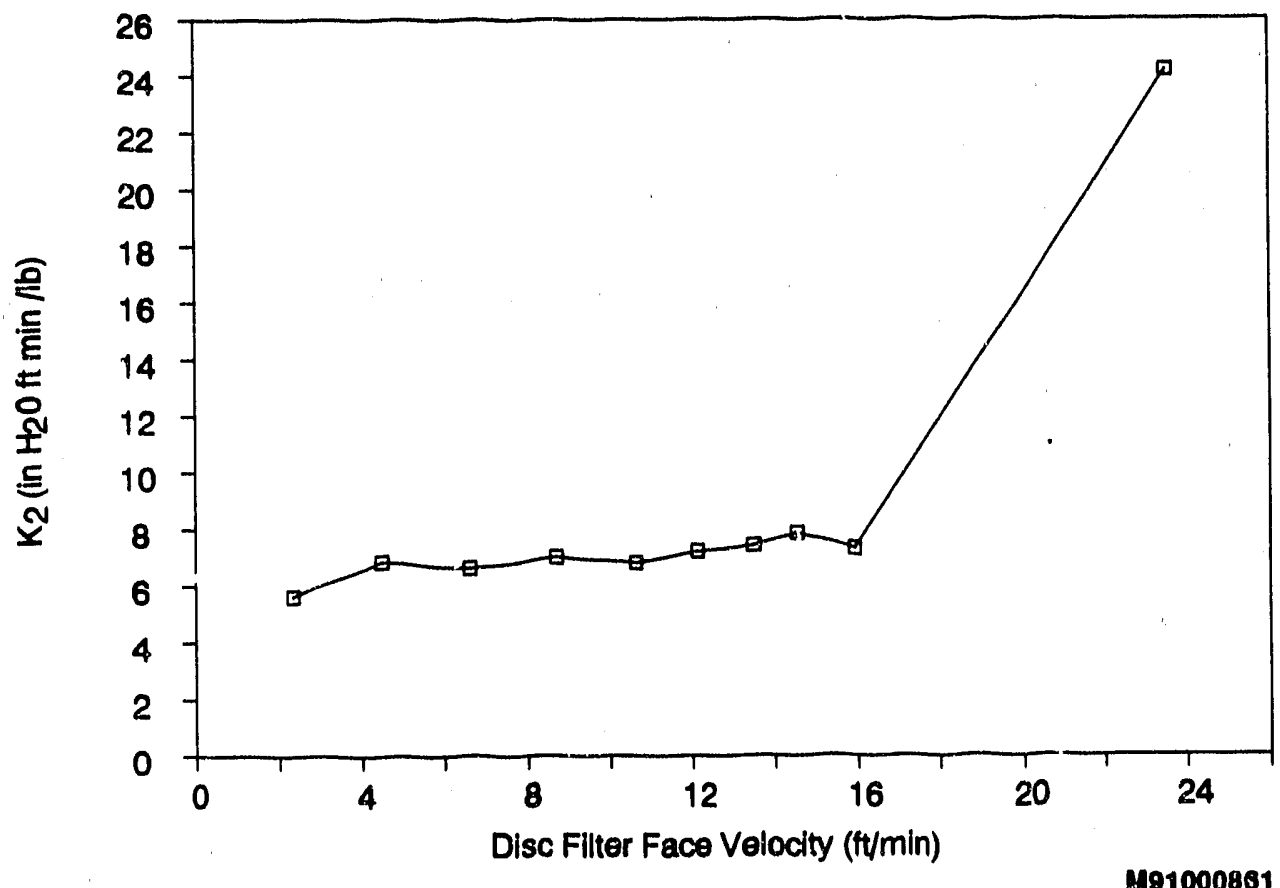

Figure 67. Iffect of race Velocity on $k_{2}$ for Disc Filter Test DF2 


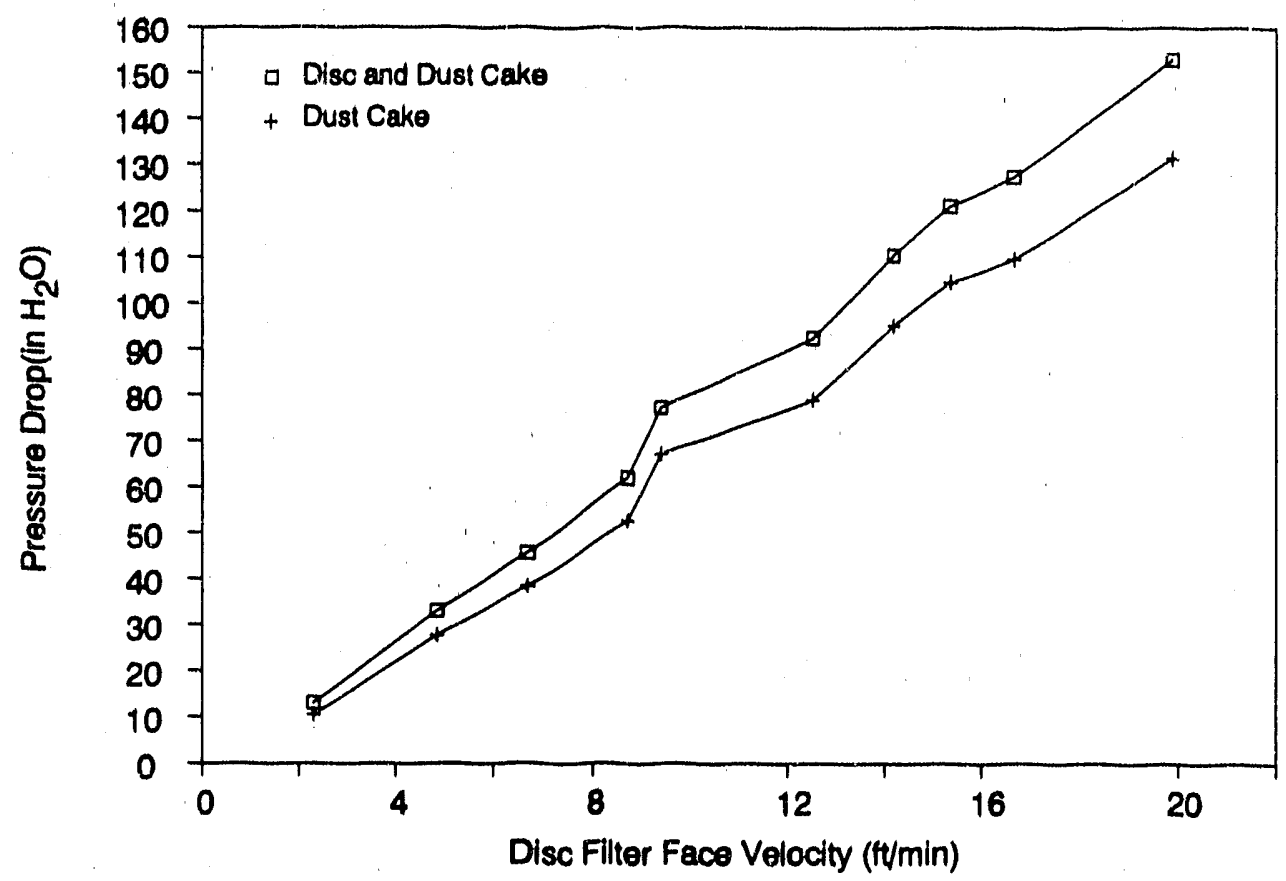

$\mathbf{M 9 1 0 0 0 8 6 2}$

Tigure 68. Effect of race Velocity on Rressure Drop Through Disc Filter and Dust Cake for Disc rilter Test Dr3

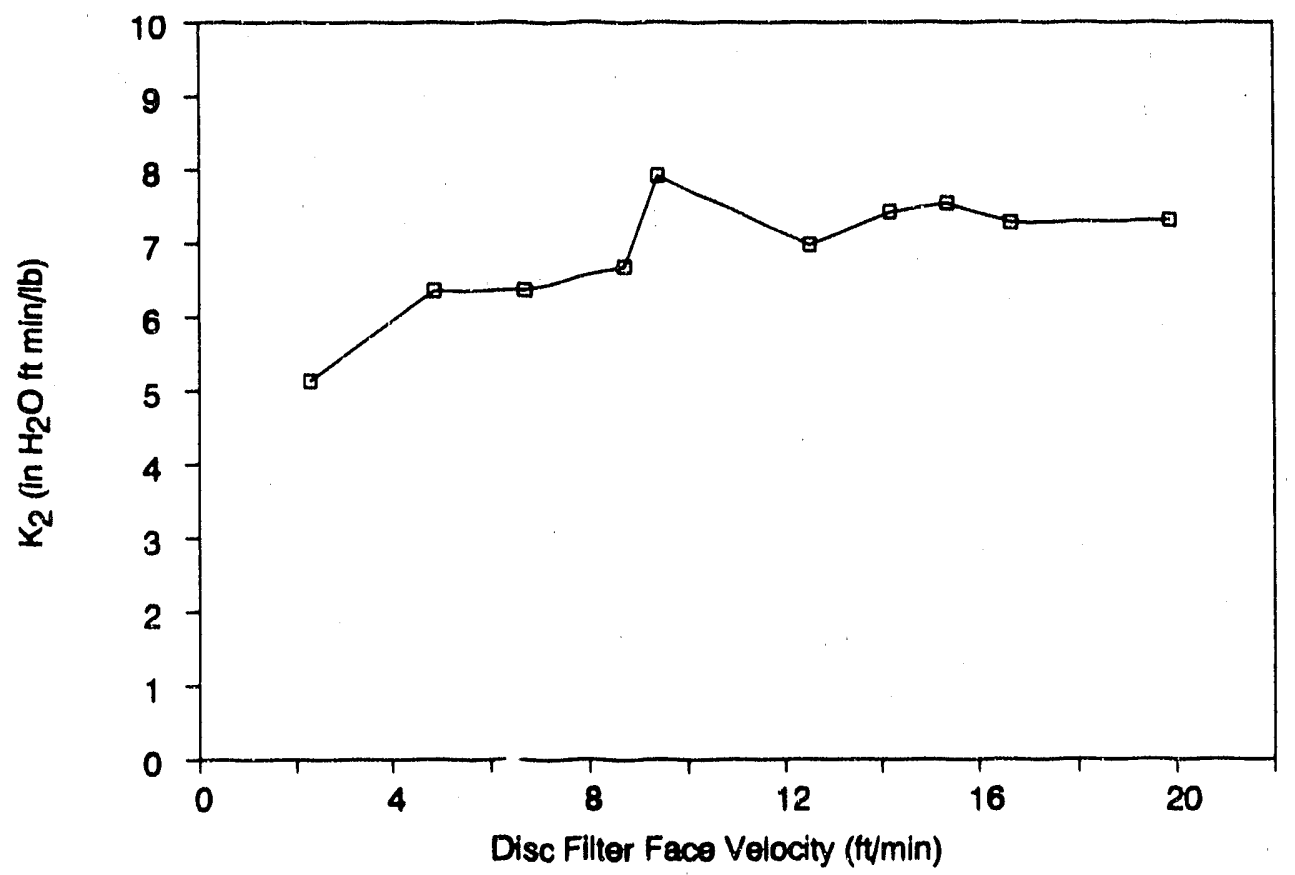

$\$ 21000863$

rigure 69. Effect of race velocity on $k_{2}$ for Disc rilter Test Dr3 


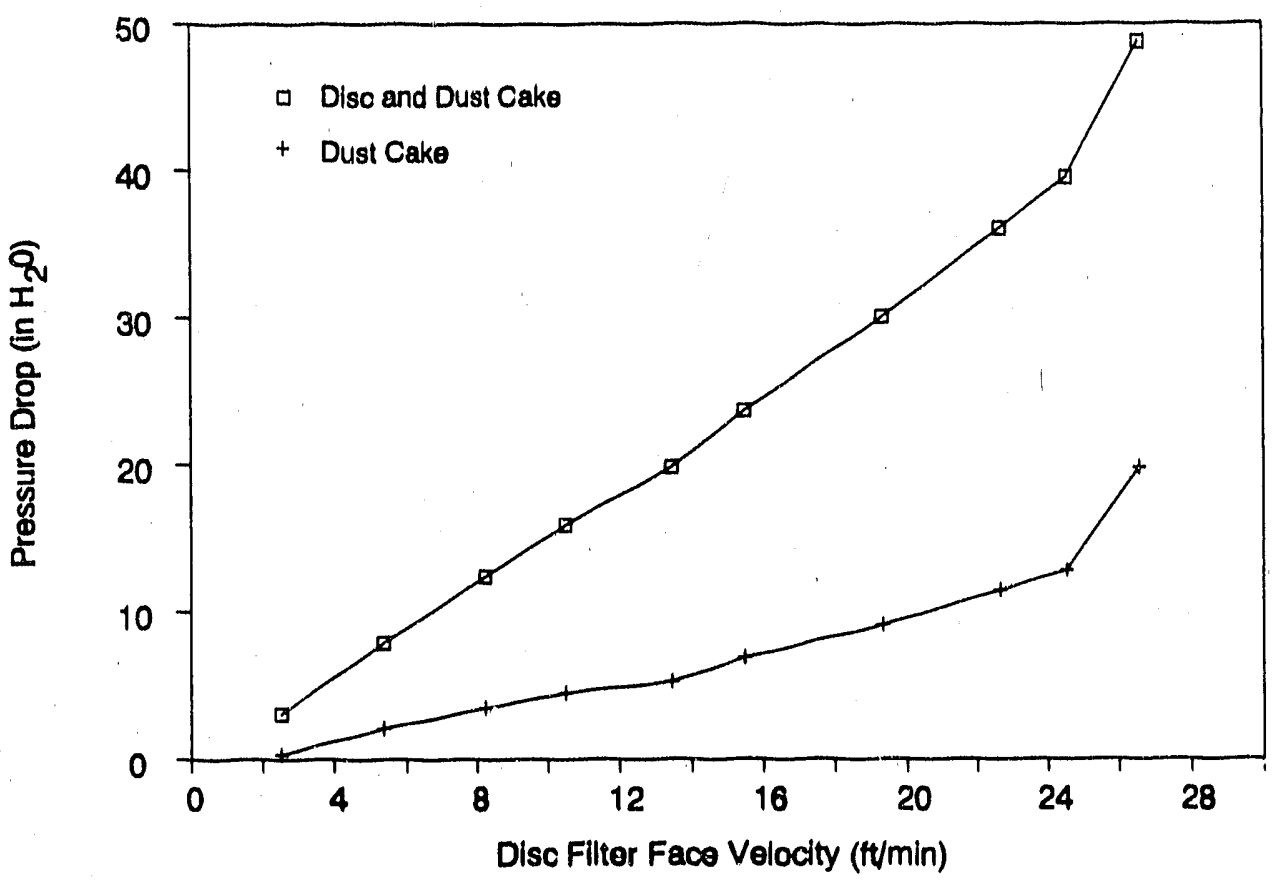

M91000864

Figure 70. Effect of race Velocity on Pressure Drop Through Disk Filter and Dust Cake for Disc rilter Test DFA

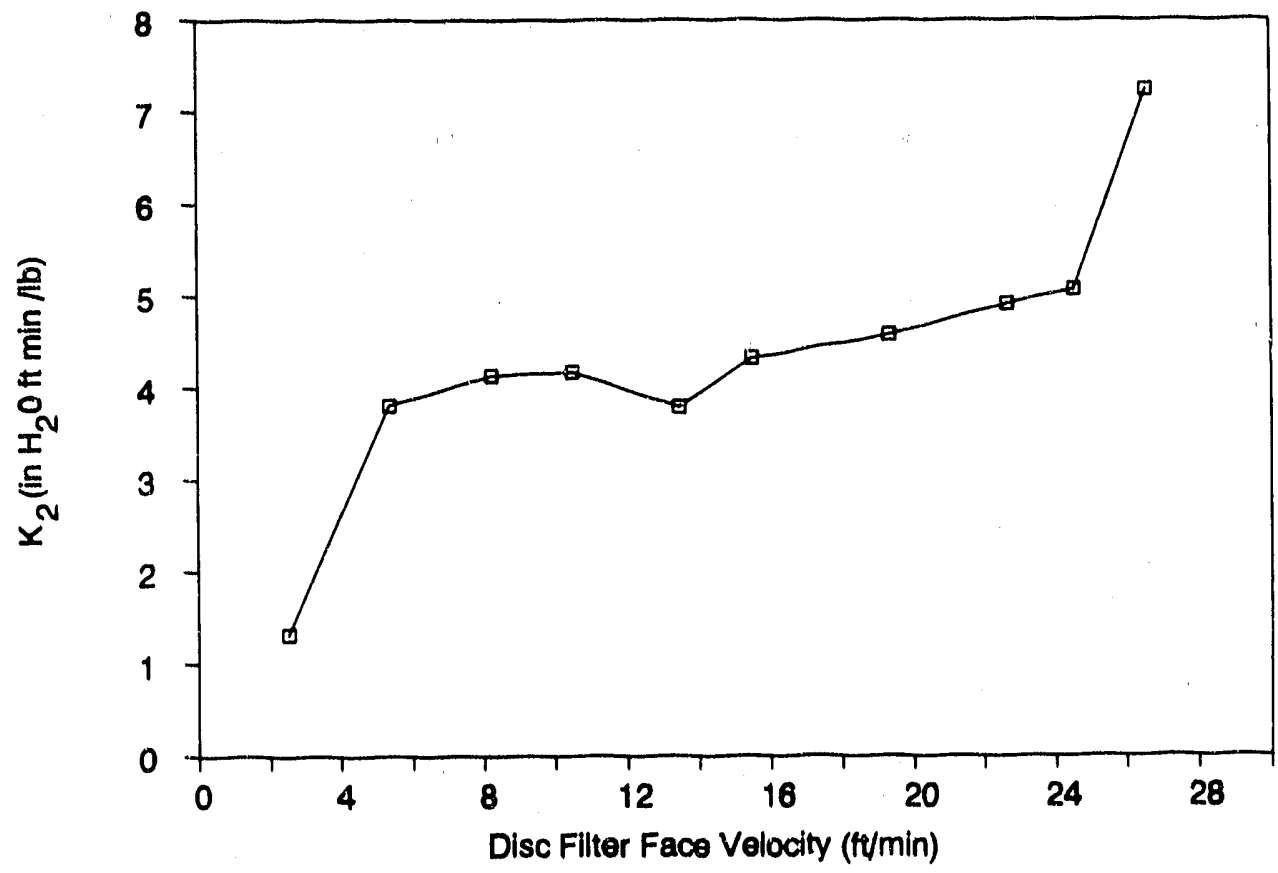

$M 91000865$

Figure 71. Effect of race velocity on $k_{2}$ for Disc Filtex rest DFA 


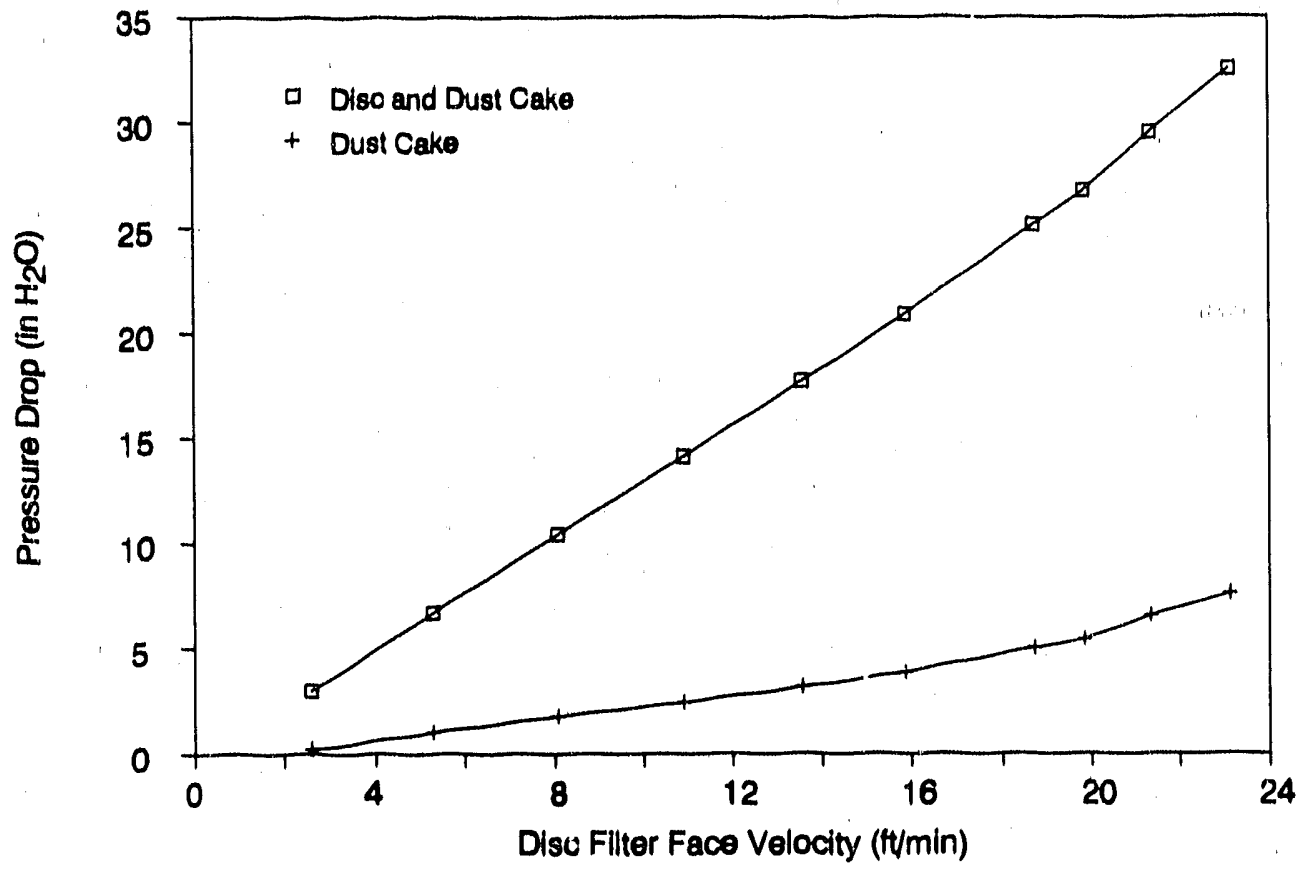

M91000866

Figure 72. Effect of Face Velocity on Pressure Drop Through Disc Iilter and Dust Cake for Disc rilter Test DF5

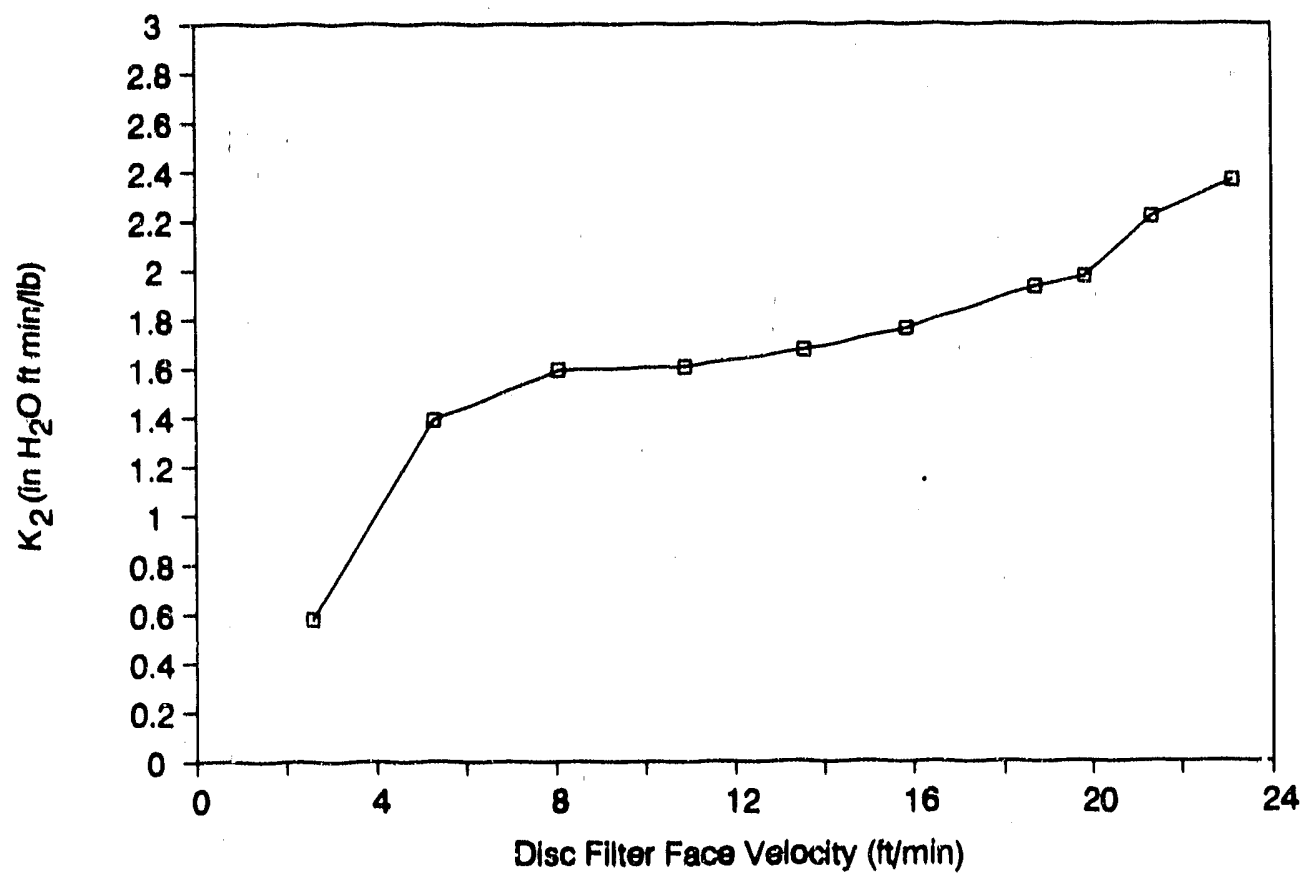

Iigure 73. Effect of Face velocity on $\pi_{2}$ for Disc riltar Test DF5 


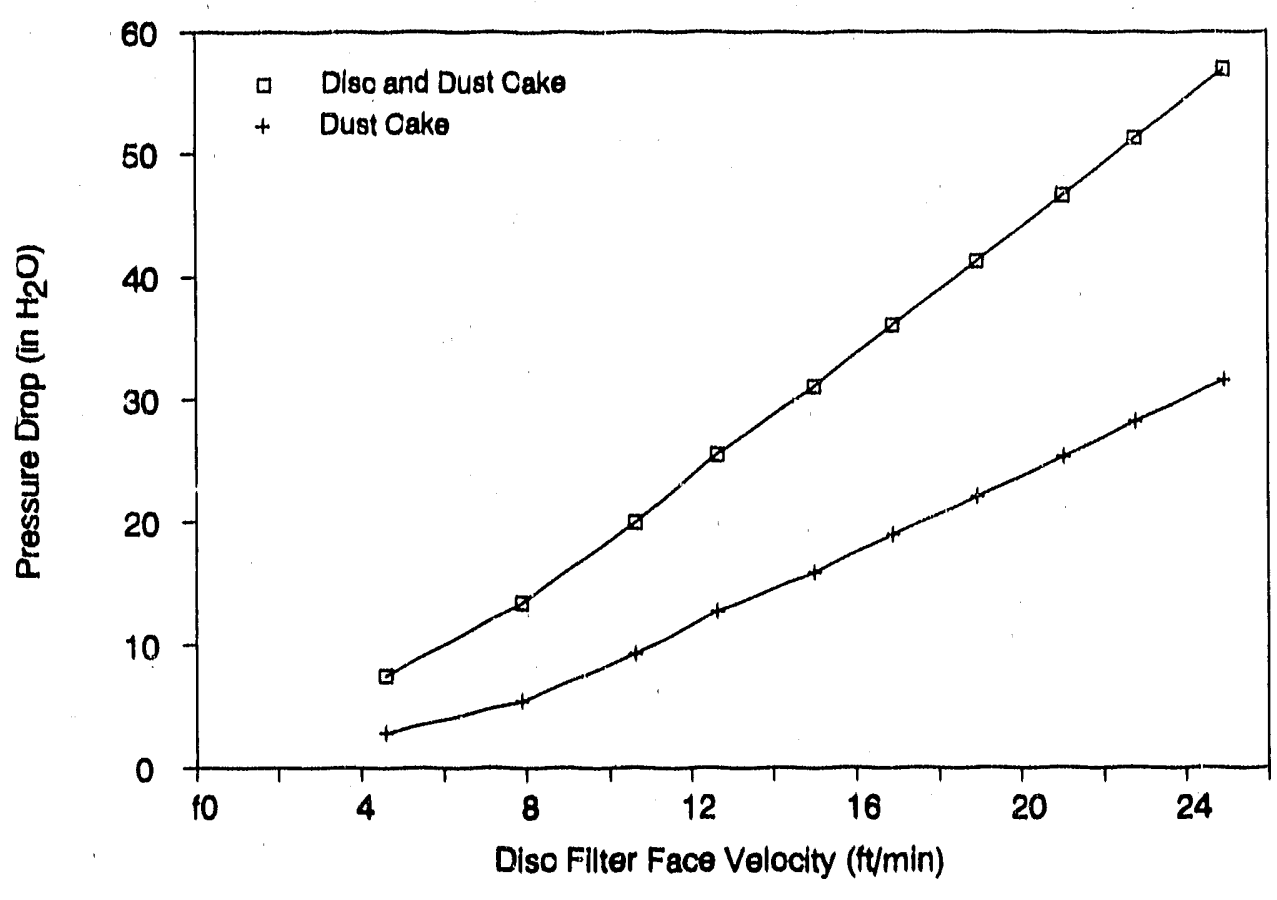

Tigure 74. Eefact of race Velocity on Pressure Drop Through Disc Filter and Dust Cake for Disc rilter Test Dr6

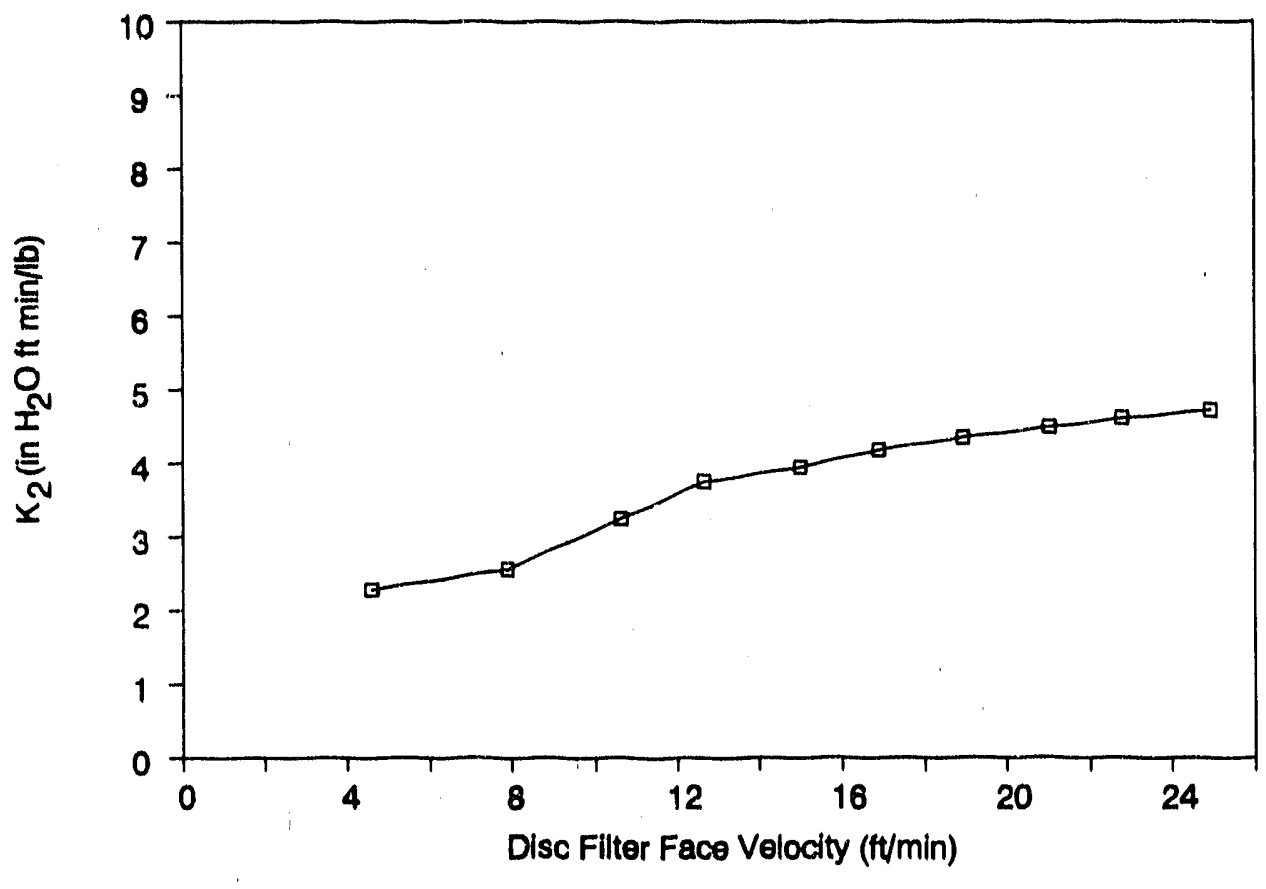

M91000869

Figure 75. Iffect of Face Velocity on $\mathrm{K}_{2}$ for Disc Filter Test Dr6 


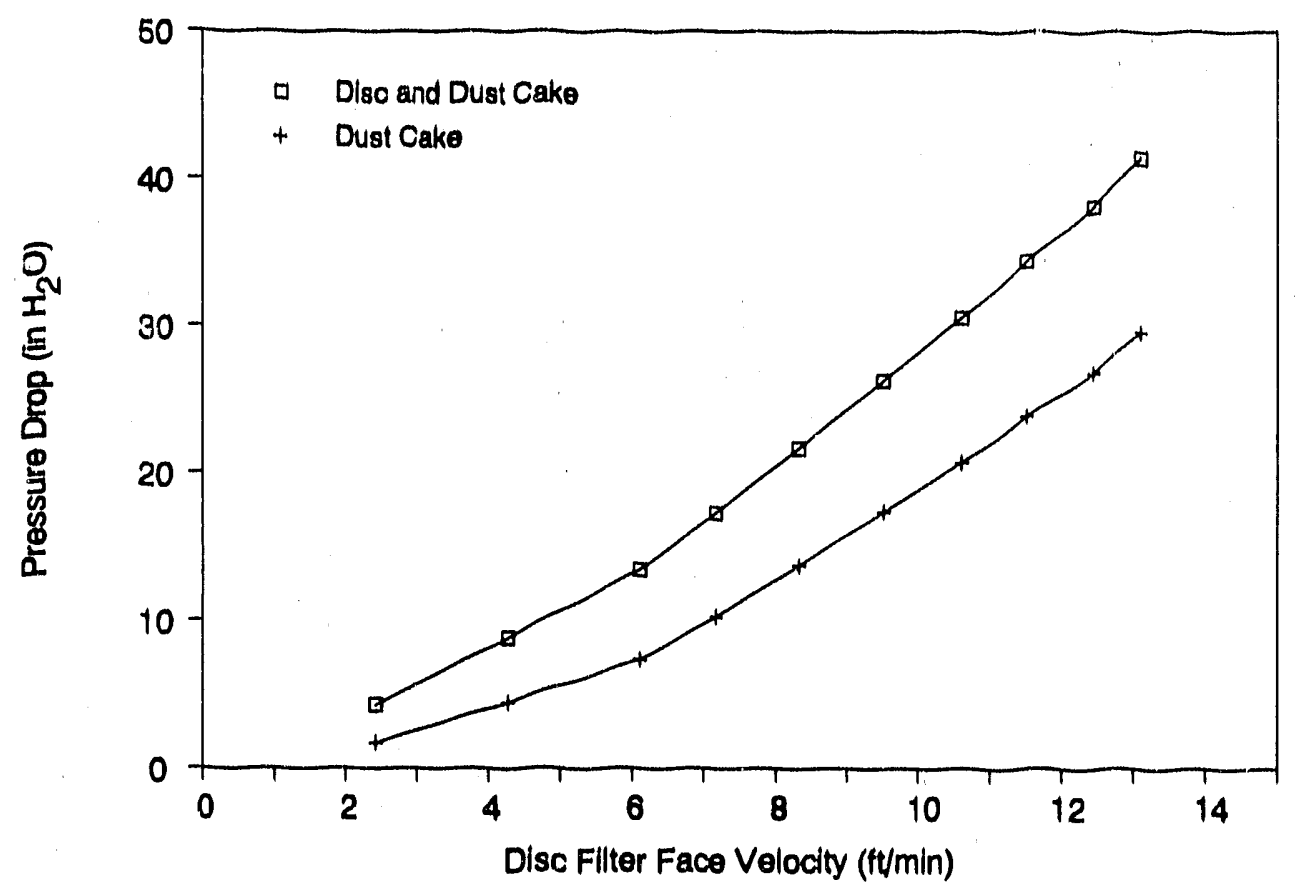

M91000870

Figure 76. Effect of Face Velocity on Pressure Drop Through Disc Filter and Dust Cake for Disc rilter Test Dr7

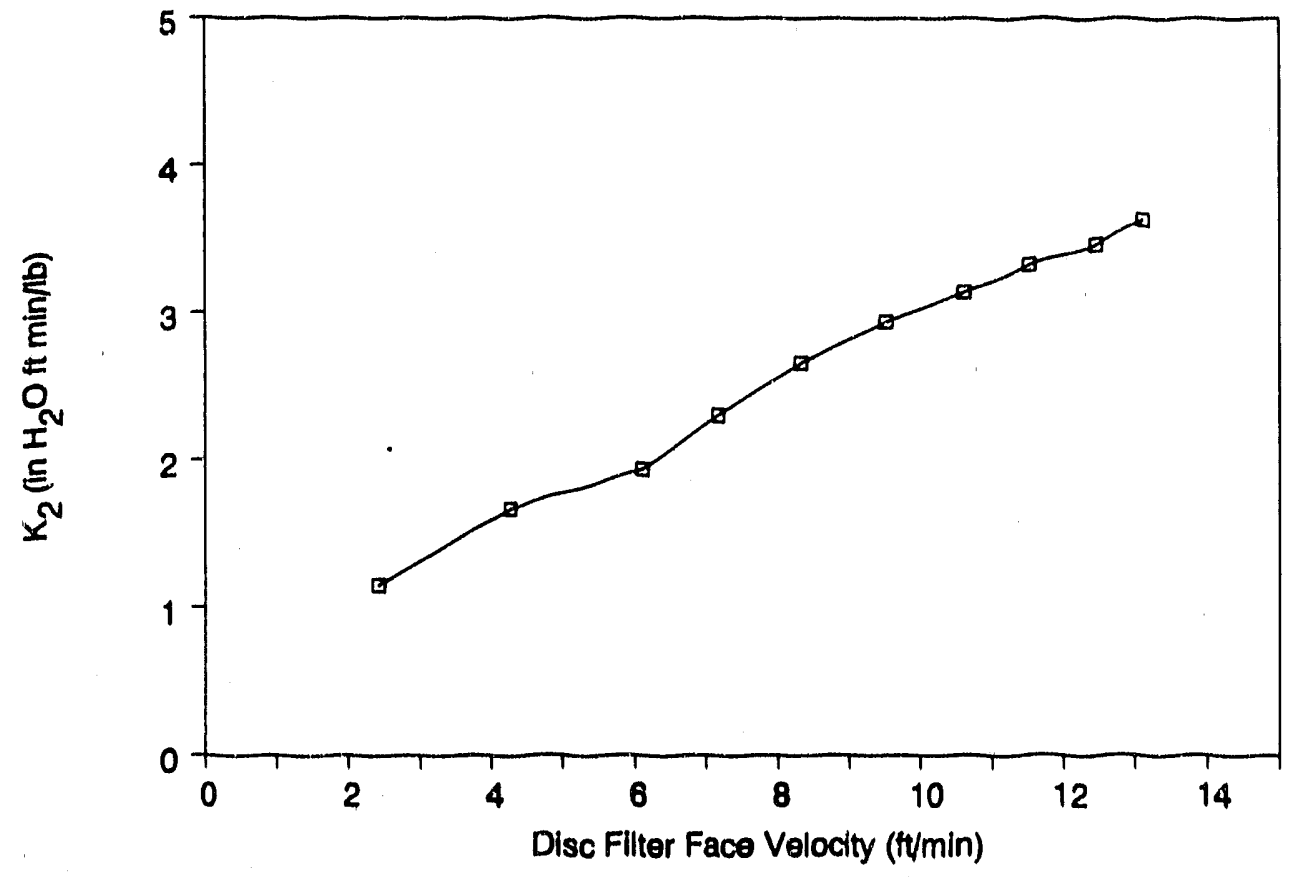

M91000871

rigure 77. Fffect of race velocity on $k_{2}$ for Disc Filter Test DF7 


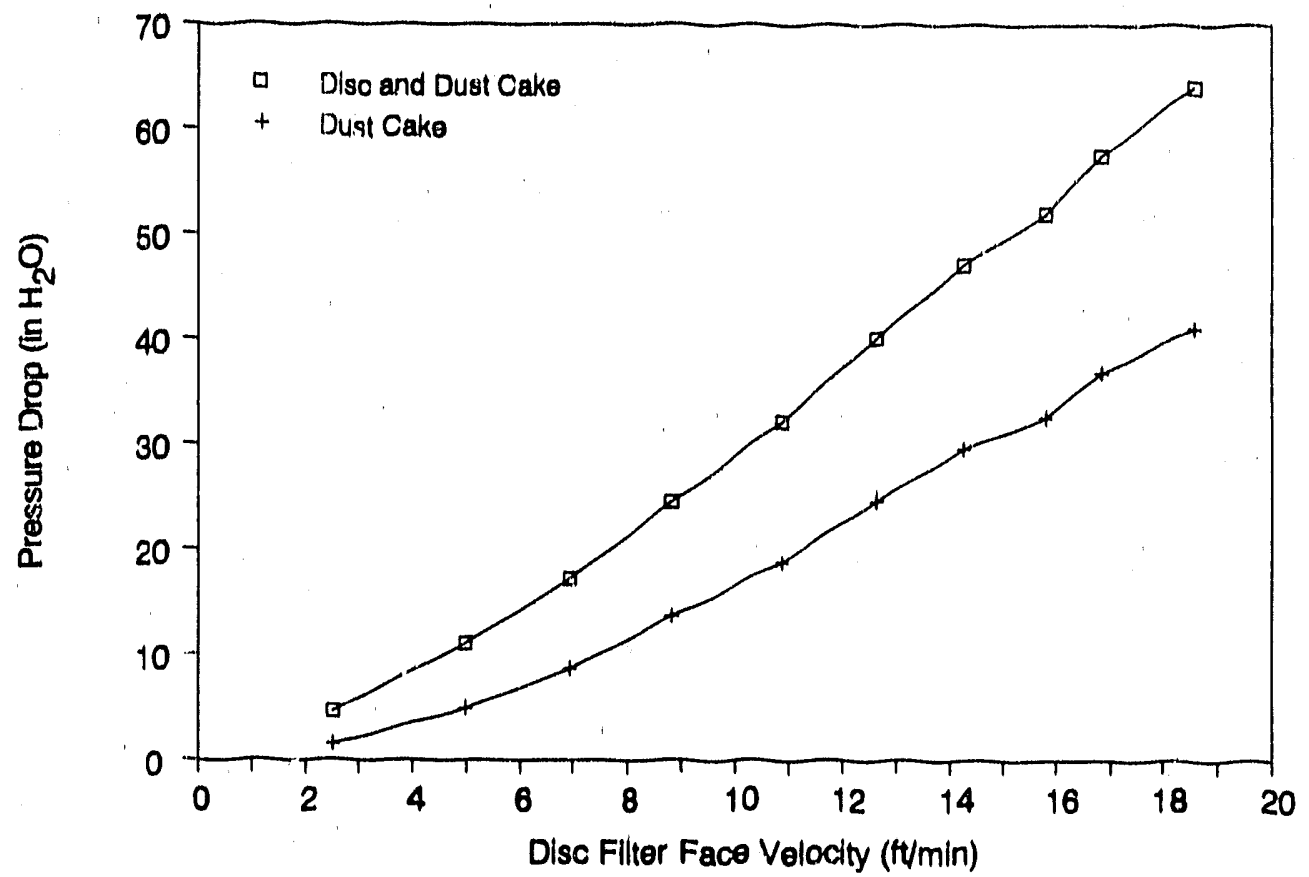

M91000872

Tigure 78. Effect of race Velocity on Pressure Drop Through Disc Tilter and Dust Cake for Disc rilter Test DF8

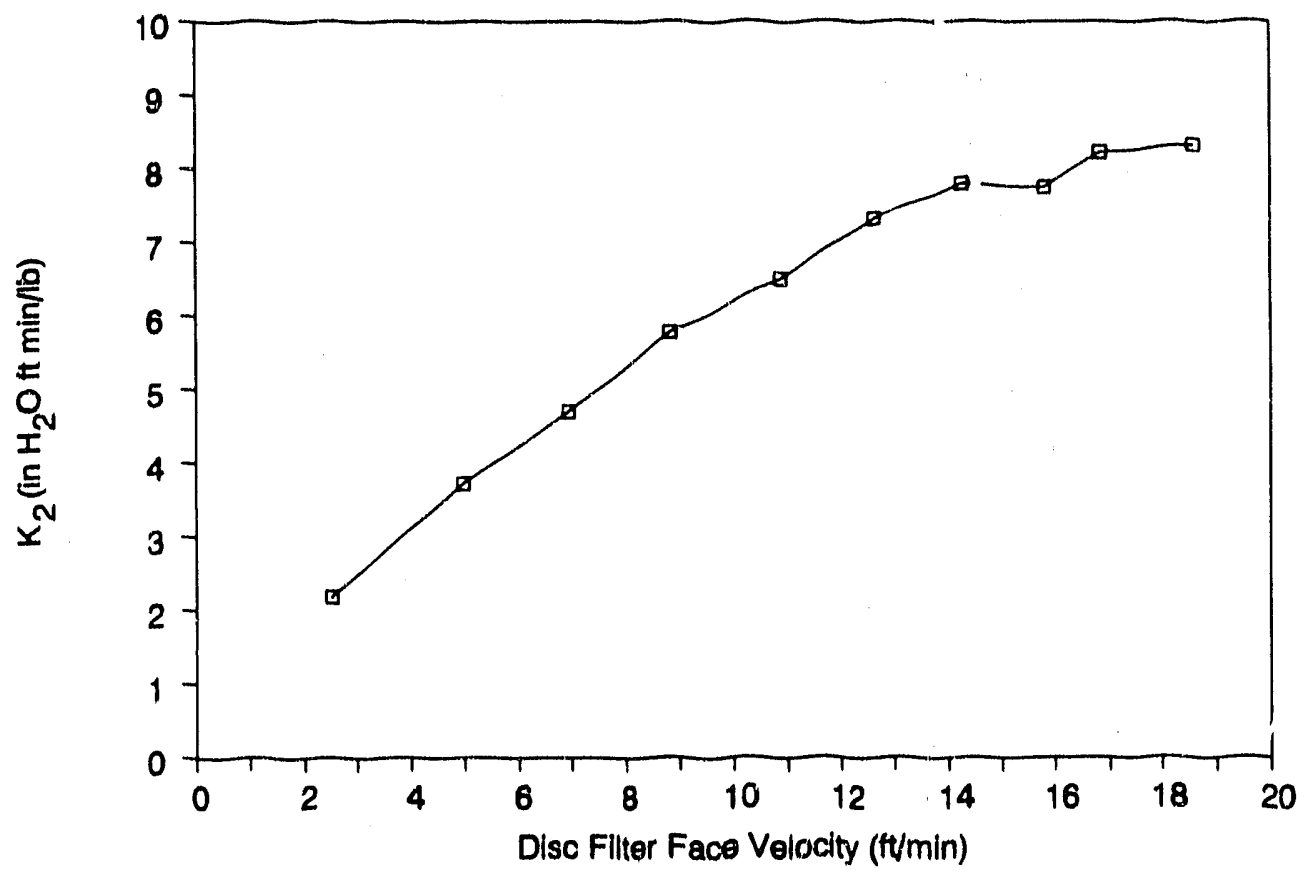

M9100087a

Figure 79. Iffect of Tace velocity on $x_{2}$ for Disc Filter Test DFB 


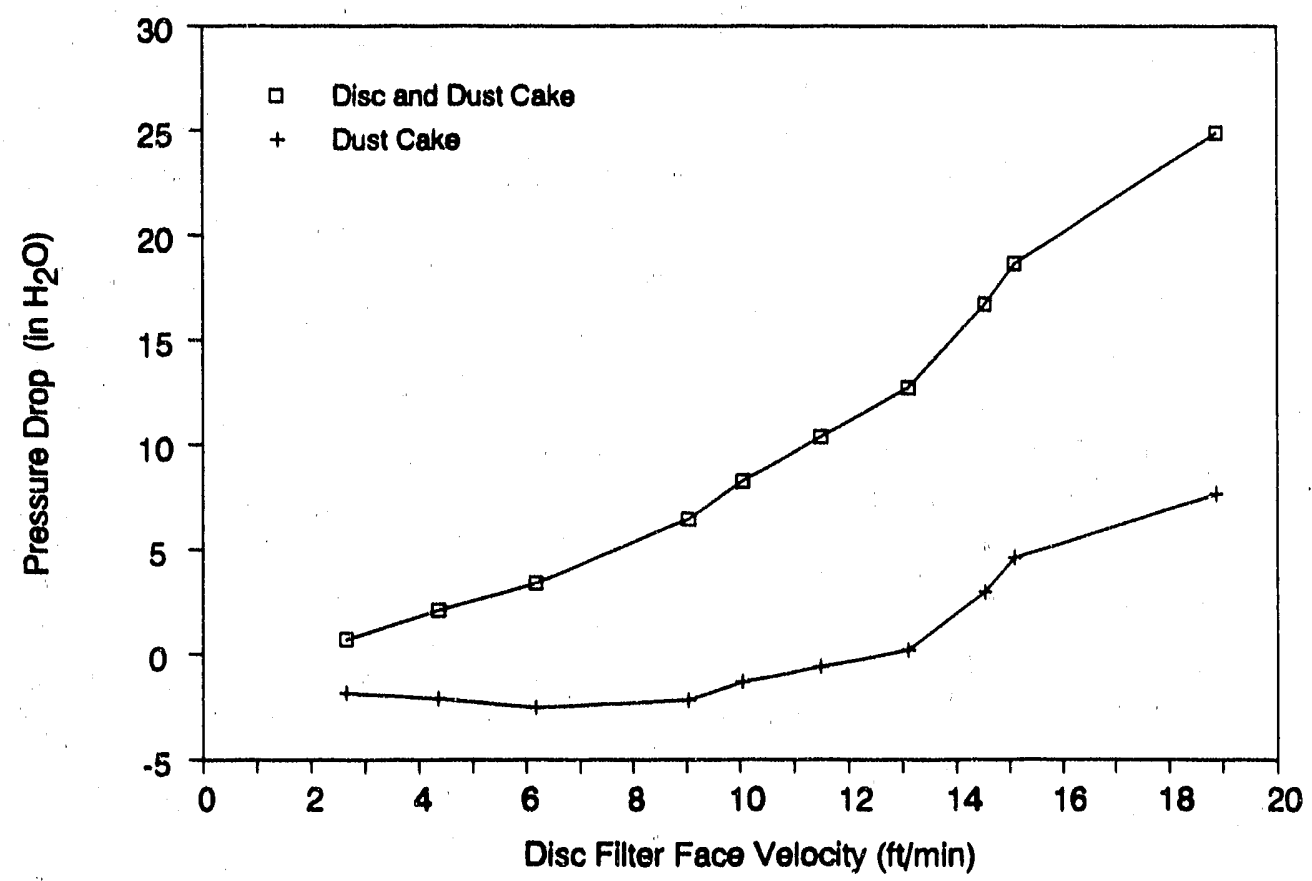

M81000874

rigure 80. Effect of race Velocity on Pressure Drop Through Disc Filter and Dust Cake for Disc Filter Test DF9

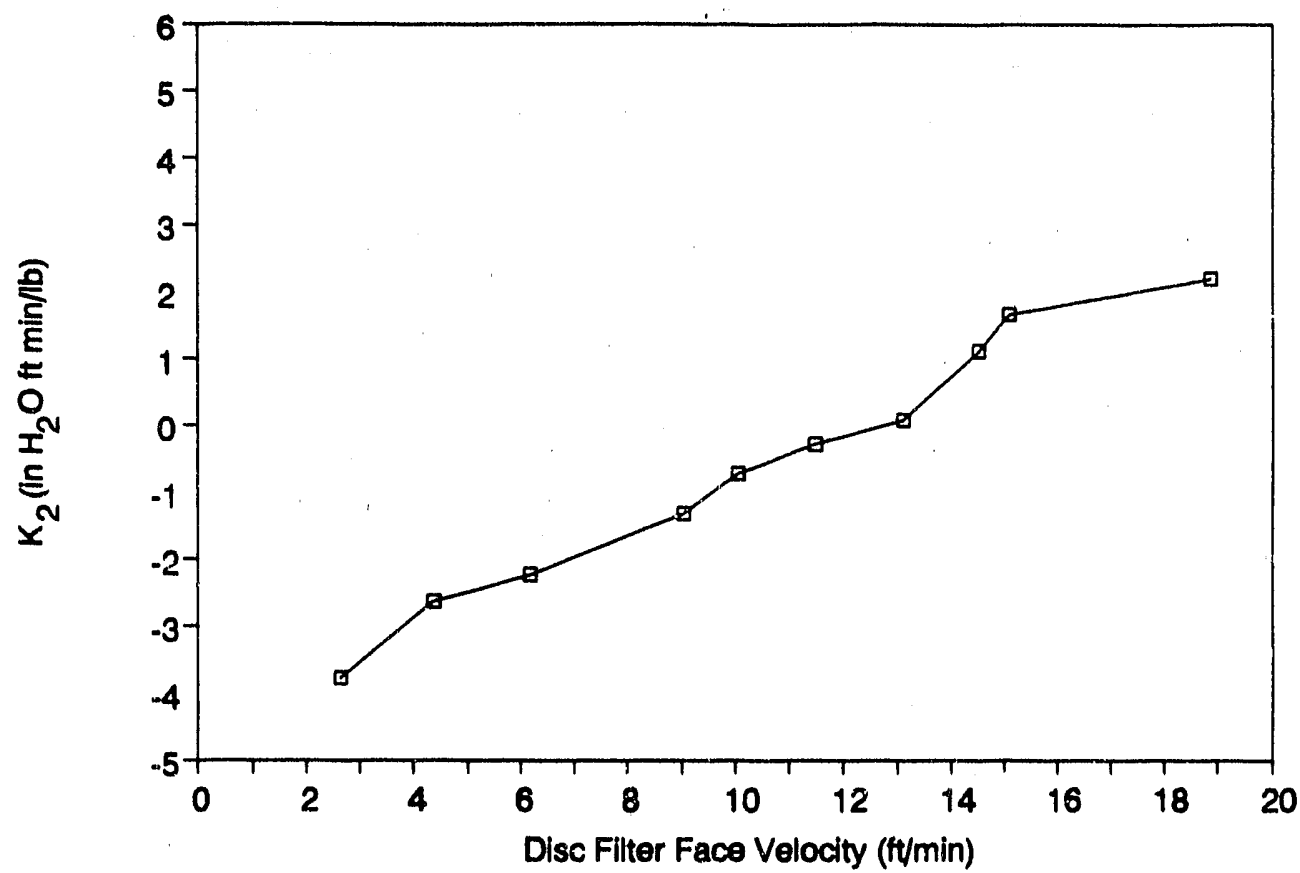

M91000875

Figure 81. Effect of race Velocity on $k_{2}$ for Disc rilter Test DF9 


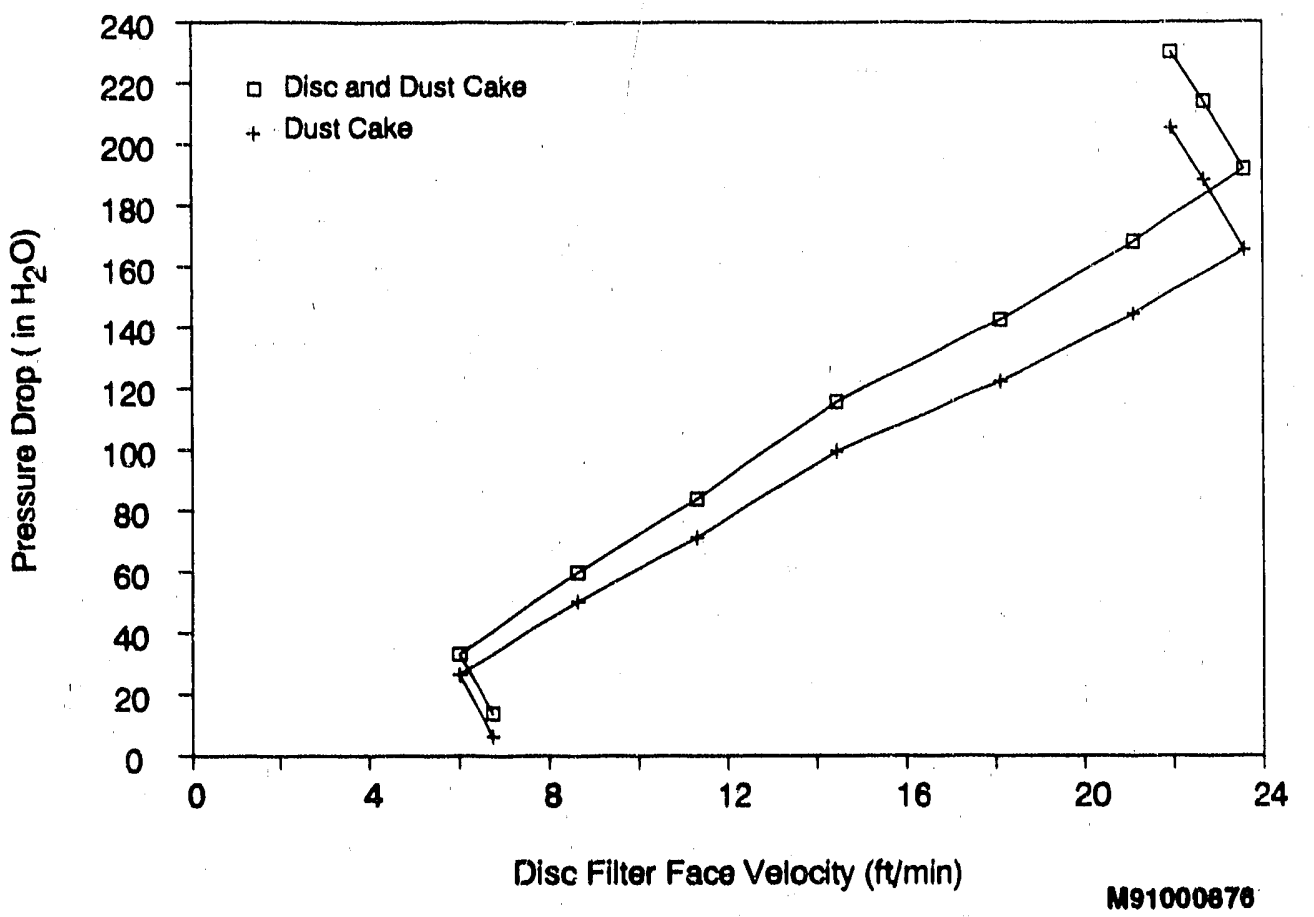

Figure 82. Effect of race Velocity on Rressure Drop Through Disc Filter and Dust Cake for Disc rilter Test Dr11

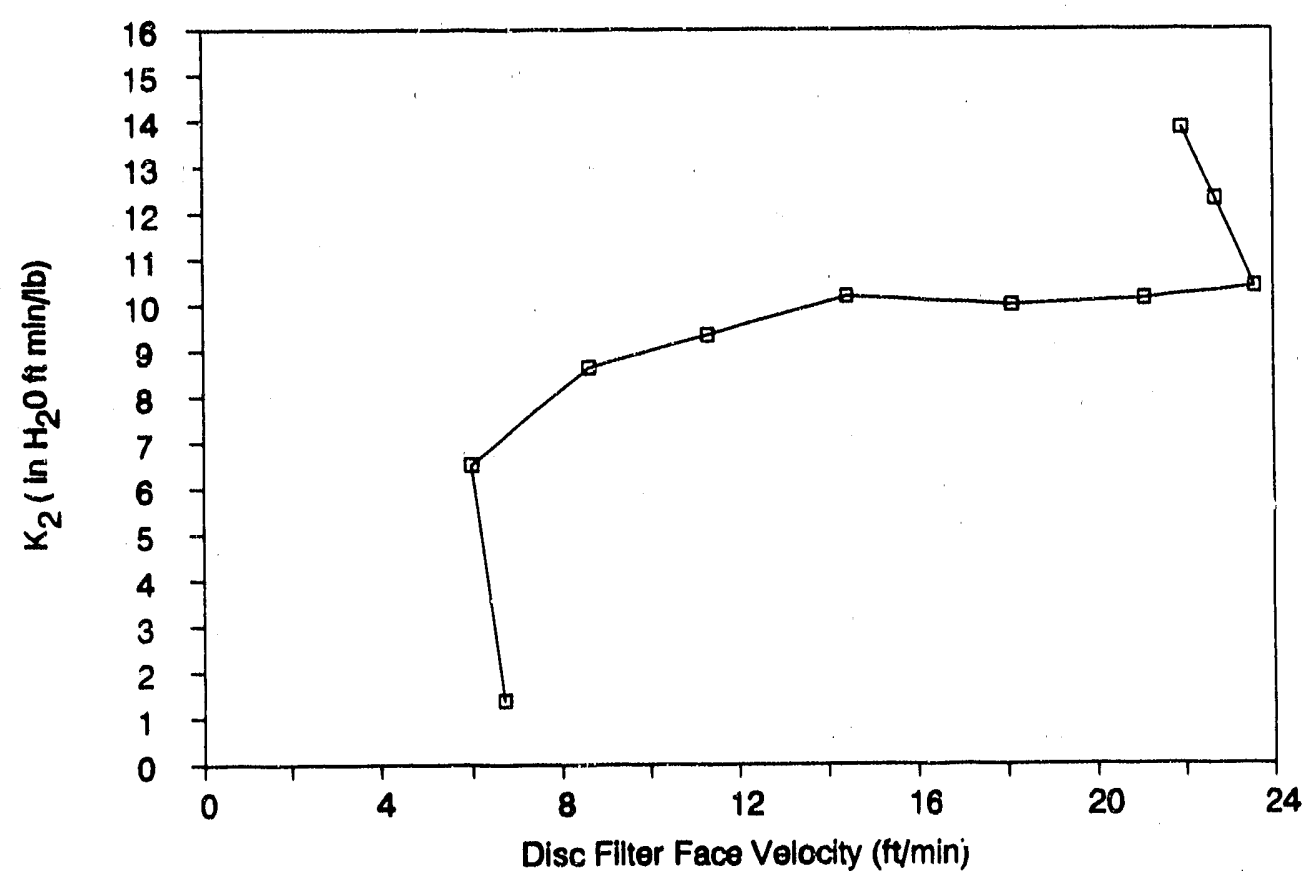

M91000877

rigure 83. Effect of Face Velocity on $k_{2}$ for Disc Filter Test Dril 
Appendix E: SFM, Chemical, and Physical Analyses of Dust Cakes in the Candle-Filter Test Series

The scanning electron microscope (SEM) photographs show bedding planes on the "cracker-like" dust cakes as rings concentric with the outside surface of the candle filter. SEM photographs taken perpendicular to the bedding planes would also be perpendicular to the candle filter surface. Photos taken rarallel to the bedding plane were tangent and longitudinal to the candle filter surface, but were elevated from the filter surface to examine the inner regions of the cracker-like cake. The material used for the SEM photographs was taken from the cracker-like samples formed during each test. The separate specimens (three for each test) analyzed in rable 12 were grab samples used to determine the mean particle size for each test. These samples were selected based on their apparent carbon content. 

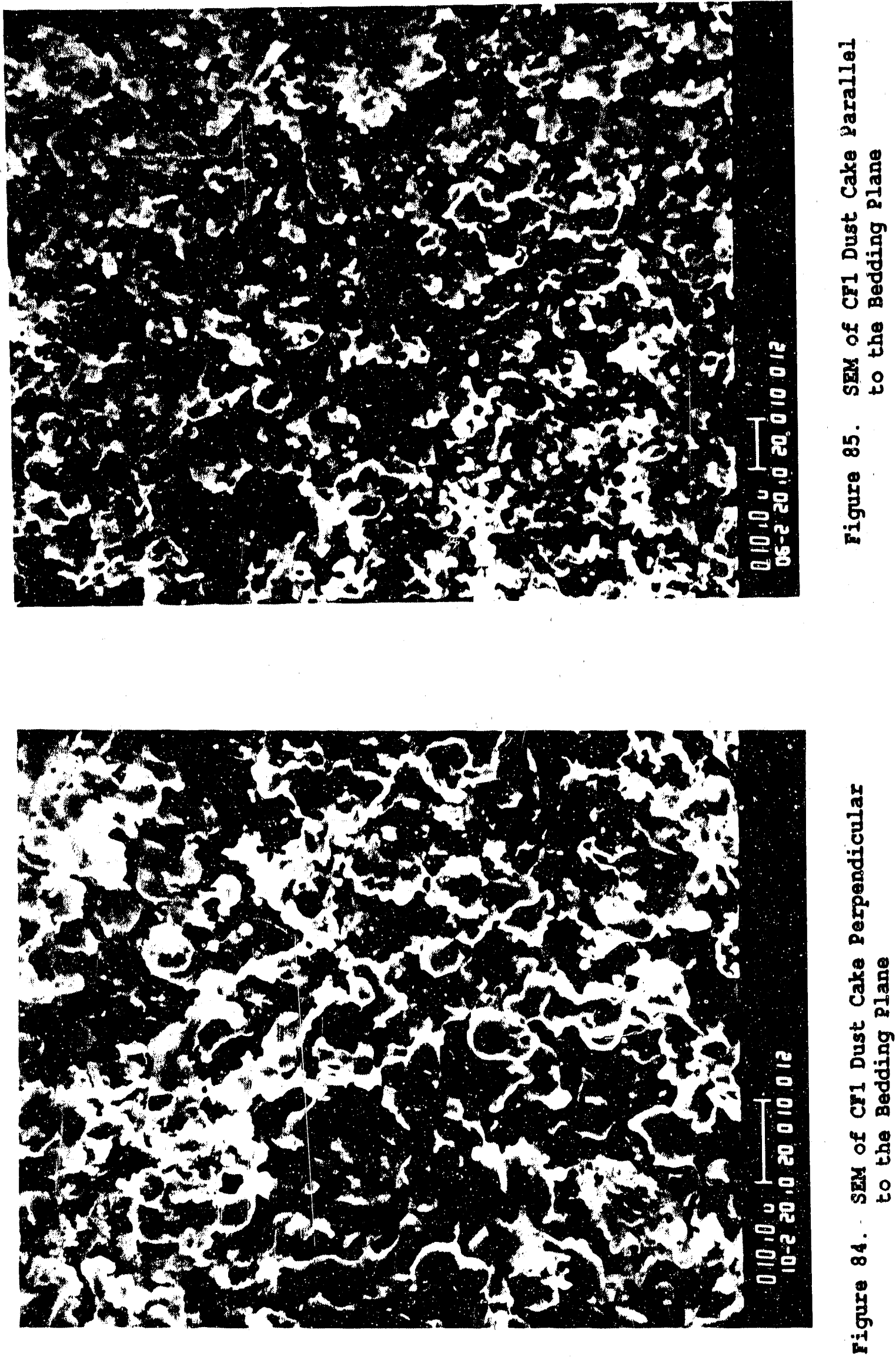

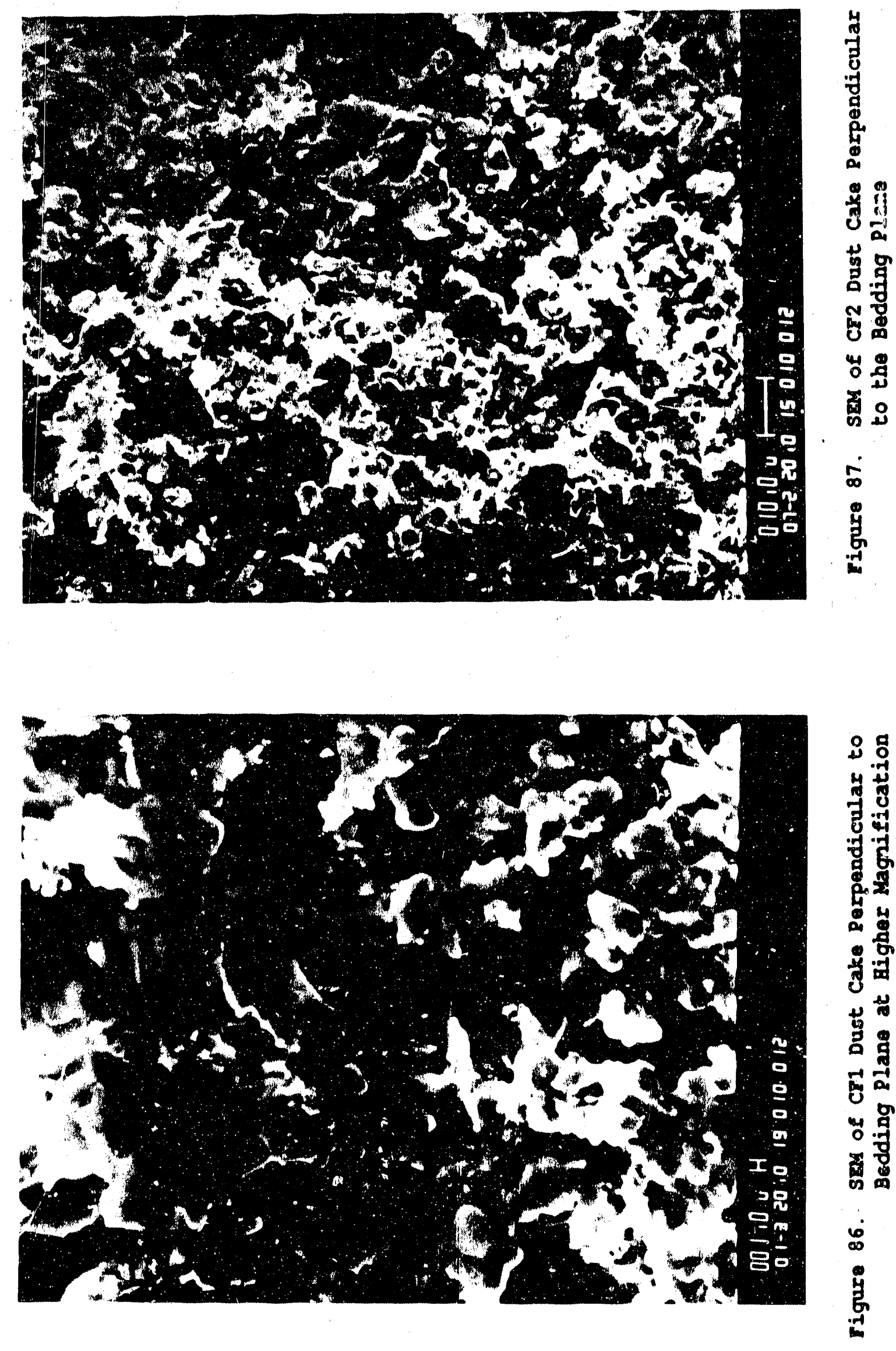

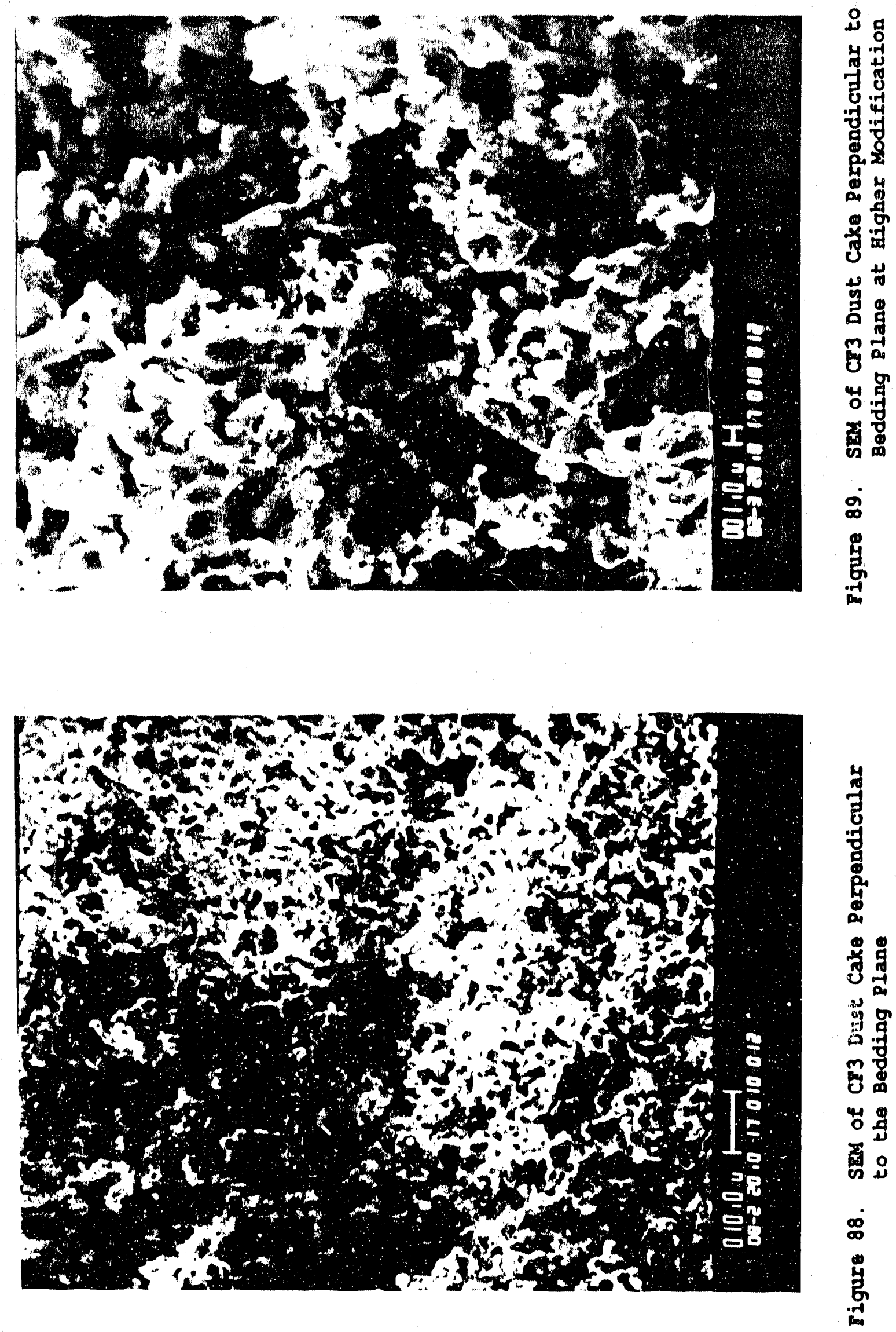
Table 12. Laboratory Analysis of Candle-rilter Dust Cakes

\begin{tabular}{|c|c|c|c|c|c|c|c|c|c|}
\hline \multirow[b]{2}{*}{ Parameter } & \multicolumn{3}{|c|}{ CF 1} & \multicolumn{3}{|c|}{ CF 2} & \multicolumn{3}{|c|}{ CF 3} \\
\hline & R11-1 & $R 11-2$ & R11-3 & R12-1 & $\mathrm{R} 12-2$ & R12-3 & R13-1 & R13-2 & R13-3 \\
\hline $\begin{array}{l}\text { Mean Particle S1ze } \\
\text { (by volume) }(\mu \mathrm{m})\end{array}$ & 6.66 & 8.51 & 5.32 & .15 .06 & 10.16 & 8.64 & 9.80 & 8.21 & 6.80 \\
\hline $\begin{array}{l}\text { Moan Particle size (by } \\
\text { population }(\mu \mathrm{m})\end{array}$ & 2.57 & 3.02 & 2.66 & 4.42 & 3.98 & 3,65 & 3.45 & 3.23 & 2.17 \\
\hline $\begin{array}{l}\text { Density (by hellum) } \\
\text { (g/oo) }\end{array}$ & 2.78 & 2.80 & 2.80 & 2.84 & 2.75 & 2.80 & 2.86 & 2.68 & 2.87 \\
\hline $\begin{array}{l}\text { BET Surface Area (via } \\
\text { nitrogen) }\left(\mathrm{m}^{2} / \mathrm{g}\right)\end{array}$ & 6.43 & 8.15 & 1.57 & 27.66 & 3.79 & 1.55 & 17.91 & 3.22 & 1.55 \\
\hline $\begin{array}{l}\text { Pore Volume, Adsorption } \\
\left.\text { (via } \mathrm{N}_{2}\right)(\mathrm{cc} / \mathrm{g})\end{array}$ & 0.0063 & 0.0058 & 0.0047 & 0.0105 & 0.0049 & 0.0024 & 0.0080 & 0.0058 & 0.0024 \\
\hline Ash (t) & 94.25 & 91.80 & 97.96 & 77.32 & 95.58 & 98.16 & 86.55 & 98.85 & 99.73 \\
\hline Carbon (t) & 3.30 & 4.94 & 0.86 & 17.74 & 2.12 & 3.33 & 10.22 & 0.57 & 0.20 \\
\hline N1trogen (t) & $<0.02$ & 0.05 & 0.06 & 0.27 & 0.02 & 0.08 & 0.17 & $<0.01$ & $<0.01$ \\
\hline Total Sulfur (t) & 6.866 & 6.808 & 4.899 & 6.698 & 5.734 & 8.122 & 5.868 & 7.64 & - \\
\hline Sulfur (t) & 4.43 & 4.15 & 3.66 & 3.21 & 4.02 & 5.22 & 3.82 & 4.97 & 4.80 \\
\hline Hydrogen (1) & $<0.01$ & $<0.01$ & $<0.01$ & 0.38 & 0.09 & $<0.01$ & 0.19 & 0.08 & 0.16 \\
\hline Molsture (1) & 0.49 & 0.44 & 0.22 & 0.74 & 0.18 & 0.15 & 0.99 & 0.22 & 0.14 \\
\hline$R_{2} O(t)$ & 2.285 & 1.960 & 1.926 & 0.840 & 1.783 & 1.684 & 1.806 & 2.16 & - \\
\hline $31 O_{2}(1)$ & 38.1 & 38.5 & 39.0 & 33.9 & 39.2 & 36.3 & 39.2 & 37.5 & -- \\
\hline $\mathrm{F} \theta_{2} \mathrm{O}_{3}(t)$ & 5.39 & 5.76 & 5.32 & 5.66 & 6.34 & 5.51 & 5.86 & 4.96 & -- \\
\hline$M g O(t)$ & 2.109 & 2.271 & 2.421 & 2.890 & 2.070 & 1.902 & 1.996 & -- & -- \\
\hline Zno (t) & 0.0078 & 0.0067 & 0.0087 & 0.0049 & 0.0067 & 0.0073 & 0.0065 & 0.009 & -- \\
\hline Sro (t) & 0.114 & 0.093 & 0.137 & 0.056 & 0.095 & 0.107 & 0.096 & -- & - \\
\hline $\mathrm{CaO}(4)$ & 16.560 & 18.758 & 16.775 & 30.492 & 16.961 & 14.645 & 16.706 & 13.46 & -- \\
\hline $\mathrm{P}_{2} \mathrm{O}_{5}$ (t) & 0.290 & 0.309 & 0.292 & 0.425 & 0.297 & 0.271 & 0.288 & 0.26 & -- \\
\hline $\mathrm{Al}_{2} \mathrm{O}_{3}(\mathrm{l})$ & 18.88 & 17.97 & 18.70 & 13.29 & 19.09 & 17.74 & 18.97 & 19.47 & - \\
\hline $\mathrm{THO}_{2}(t)$ & 0.84 & 0.72 & 0.88 & 0.36 & 0.75 & 0.75 & 0.73 & - & - \\
\hline Mno (\$) & 0.006 & 0.006 & 0.006 & 0.005 & 0.003 & 0.002 & 0.004 & 0.00 & -- \\
\hline Ash Fusion ID $\left({ }^{\circ} \mathrm{F}\right)$ & 2,120 & -- & -- & - & - & 2,180 & -- & - & 2,260 \\
\hline Ash Fusion ST $\left({ }^{\circ} \mathrm{F}\right)$ & 2,220 & -- & $-\infty$ & - & - & 2,305 & - & - & 2,345 \\
\hline Ash Fusion HT $\left({ }^{\circ} \mathrm{F}\right)$ & 2,235 & -- & -- & - & -- & 2,345 & -- & -- & 2,365 \\
\hline Ash rusion FT $\left({ }^{\circ} \mathrm{F}\right)$ & 2,290 & -- & - & - & -- & 2,450 & - & $\cdots$ & 2,470 \\
\hline
\end{tabular}

Notes wo could not perform olomental aralyolo by XRE on Sample RI3-3 because the pollot foll apart. 


\section{Appendix I: Laboratory Characterization of Iilter Dust by Southern Research Institute}

Appendix F' is a table listing Southern Research Institute's standard laboratory analysis of dust samples from the candle filter test series.

Table 13. Laboratory Analysis of Dust Samples

\begin{tabular}{|c|c|c|c|}
\hline \multirow[b]{2}{*}{ Parameter } & \multicolumn{3}{|c|}{ Sample Identification } \\
\hline & CF1 & CF2 & CF3 \\
\hline $\begin{array}{l}\text { Specific Surface } \\
\text { Area }\left(\mathrm{m}^{2} / \mathrm{g}\right)\end{array}$ & 5.2 & 20.3 & 13.3 \\
\hline $\begin{array}{l}\text { Uncompacted Bulk } \\
\text { Porosity }\left(\frac{6}{6}\right)\end{array}$ & 86.0 & 72.4 & 81.8 \\
\hline $\begin{array}{l}\text { Estimated Dust Cake } \\
\text { Porosity (z) }\end{array}$ & 83 & $-w^{1}$ & 80 \\
\hline $\begin{array}{l}\text { Drag-Equivalent } \\
\text { Diameter }(\mu \mathrm{m})\end{array}$ & 1.23 & 4.05 & 1.81 \\
\hline $\begin{array}{l}\text { Relative Gas Flow } \\
\text { Resistance (in } \\
\mathrm{H}_{2} \mathrm{O} \mathrm{ft} \mathrm{min} / \mathrm{lb} \text { ) }\end{array}$ & 3.0 & 1.3 & 2.4 \\
\hline
\end{tabular}

1 The estimated dust cake porosity was not determined since the sample contained a yignificant anount of unburned char particles with a high surface area. Consequently, the relative gas flow resistance was calculated with the uncompacted bulk porosity. 

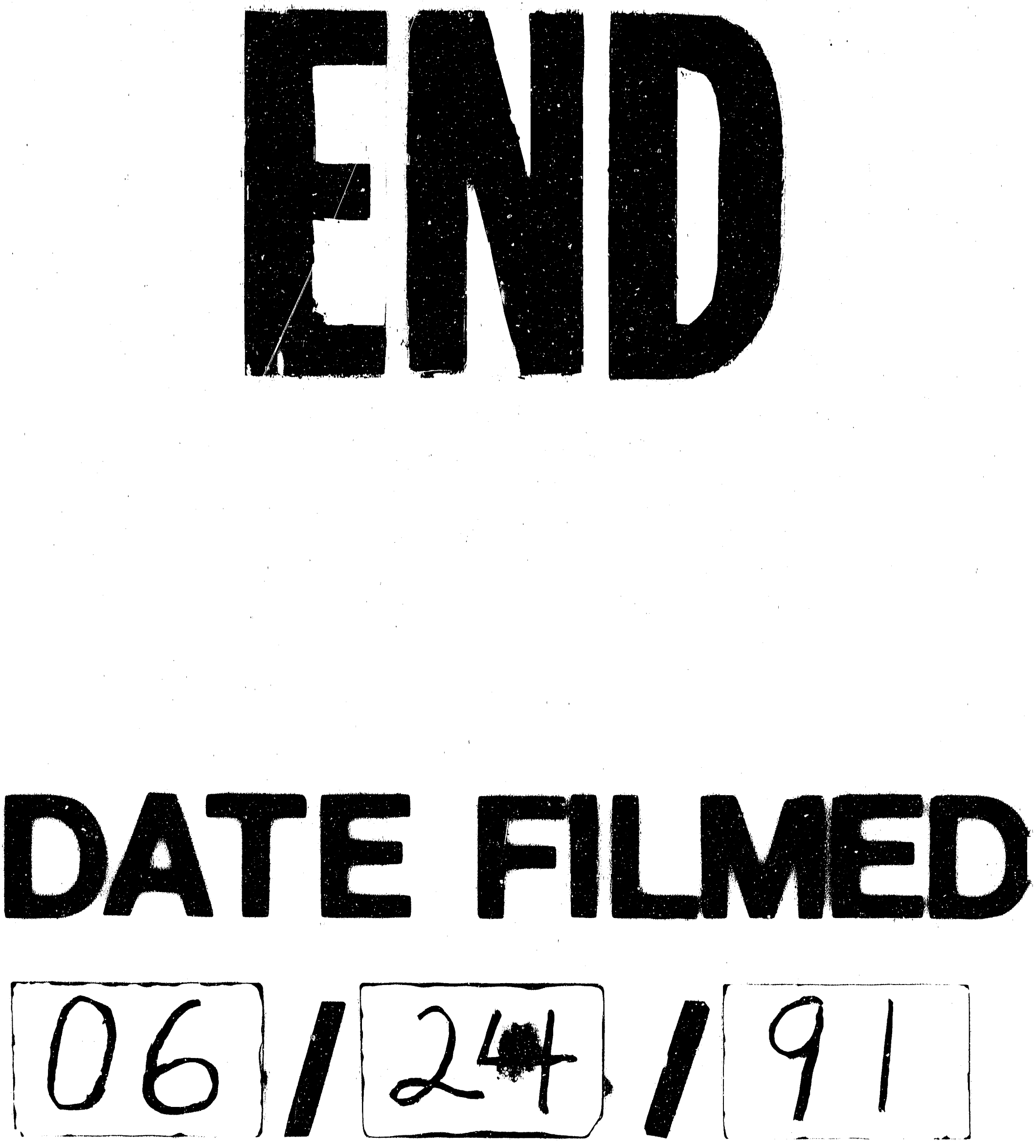
